UNIVERSIDADE DE SĀO PAULO

INSTITUTO DE GEOCIENCIAS

\title{
TAFOFLORA NEOCARBONIFERA DA FAZENDA SANTA MARTA, INTERGLACIAL DO SUBGRUPO ITARARÉ, GRUPO TUBARÃO, BACIA DO PARANÁ, REGIÃO DE ITAPEVA (SP), BRASIL.
}

Ana Paula Zampirolli

Orientadora: Profa. Dra. Mary E. C. Bernardes-de-Oliveira

DISSERTAÇÃO DE MESTRADO

Programa de Pós-Graduação em Geologia Sedimentar

SÃO PAULO

2001 


\section{UNIVERSIDADE DE SÃO PAULO \\ INSTITUTO DE GEOCIENNCIAS}

\section{TAFOFLORA NEOCARBONÍFERA DA FAZENDA SANTA MARTA, INTERGLACIAL DO SUBGRUPO ITARARÉ, GRUPO TUBARÃO, BACIA DO PARANÁ, REGIÃO DE ITAPEVA (SP), BRASIL}

\section{ANA PAULA ZAMPIROLLI}

Orientadora: Dra ${ }^{\mathrm{a}}$ Mary Elizabeth Cerruti Bernardes de Oliveira

DISSERTAÇÃO DE MESTRADO

COMISSÃO JULGADORA

Nome

Assinatura

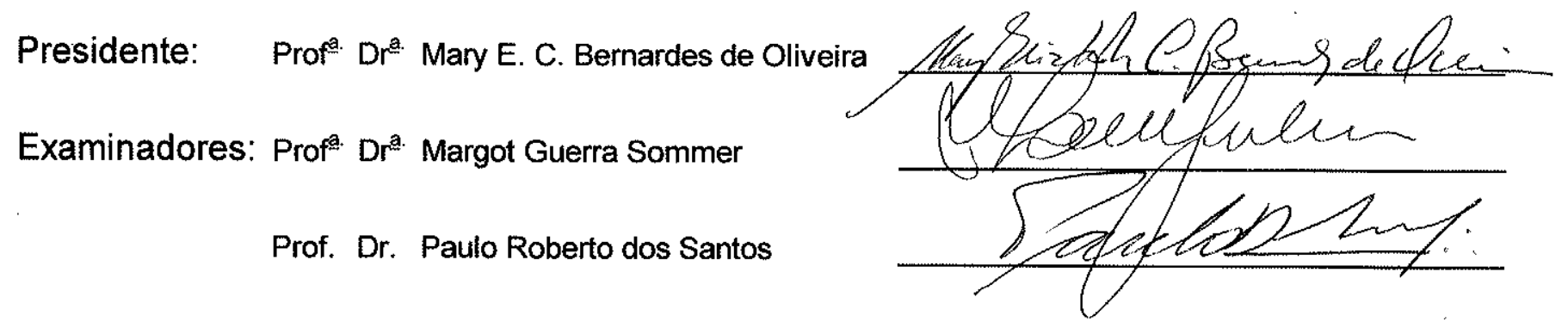

SÃO PAULO

2001 


\section{UNIVERSIDADE DE SÃO PAULO \\ INSTITUTO DE GEOCIÊNCIAS}

\section{TAFOFLORA NEOCARBONÍFERA DA FAZENDA SANTA MARTA, INTERGLACIAL DO SUBGRUPO ITARARÉ, GRUPO TUBARÃO, BACIA DO PARANÁ, REGIÃO DE ITAPEVA (SP), BRASIL.}

\section{Ana Paula Zampirolli}

Orientadora: Prof ${ }^{a}$. Dr ${ }^{a}$. Mary E.C. Bernardes-de-Oliveira

DISSERTAÇÃO DE MESTRADO

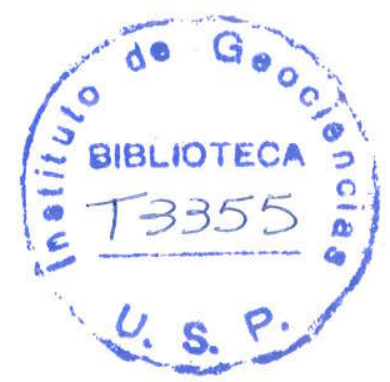

Programa de Pós-Graduação em Geologia Sedimentar

$$
\begin{gathered}
\text { SÃO PAULO } \\
2001
\end{gathered}
$$

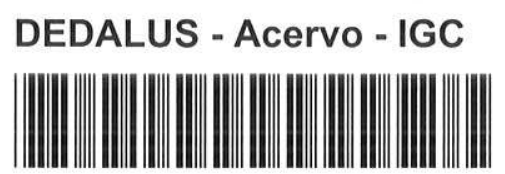


"E disse: Produza a terra relva, ervas que dêem semente, $e$ árvores frutíferas que dêem fruto segundo a sua espécie, cuja semente esteja nele, sobre a terra. E assim se fez. A terra, pois, produziu relva, ervas que davam semente segundo a sua espécie, e árvores que davam fruto, cuja semente estava nele, conforme a sua espécie. E viu Deus que isso era bom ...”. 
Dedico,

Ao meu querido esposo Ronaldo, companheiro em todos os momentos, a minha amada filha Ana Luiza, luz da minha vida e aos meus queridos pais, José Antonio e Odécia. 


\section{Resumo}

A Tafoflora Santa Marta, bairro Guarizinho, Município de Itapeva (SP) da porção mediana basal do Subgrupo Itararé, foi noticiada, primeiramente, por Millan et al. (1982) seguindo-se uma série de trabalhos sobre seus elementos componentes publicados por aquele autor entre 1987 e 1995. Constitue agora, tema dessa dissertação de mestrado.

O levantamento e revisão de seus componentes tafoflorísticos vêm sendo efetuados sob a égide do Projeto Temático FAPESP 97/03639-8, intitulado: "Levantamento da Composição e sucessão paleoflorísticas do NeocarboníferoEopermiano (Grupo Tubarão) no Estado de São Paulo".

Os fitofósseis, constituintes dessa tafoflora, são provenientes da entrada da antiga e abandonada mina de carvão da fazenda Santa Marta. Constituem-se de impressões delicadas de caules, folhas e sementes, abundantemente acumulados e superpostos, preservados em meio a material detrítico siltico-argiloso, marrom-claro, apresentando-se muito fragmentados.

A assembléia fitofossilífera estudada corresponde ao material depositado no Museu Nacional UFRJ, coletado por Millan, e nesta dissertação, revisado e acrescido de novas coletas do referido jazigo. Essas foram depositadas na Coleção Científica do Laboratório de Paleontologia Sistemática do IGc-USP.

A partir desses estudos, sua composição geral pode ser assim discriminada: Macroflora: Esfenópsidas (Sphenophyllum cf. S. churulianum, Sphenophyllum cf. S. rhodesii, Sphenophyllum sp. A, cf. Koretrophyllites sp., Paracalamites australis nov. emend., Paracalamites levis nov. emend., Paracalamites montemorensis nov. emend., Paracalamites sp.); Pteridófilas/Progimnospermópsidas (Botrychiopsis plantiana, cf. Eusphenopteris sp., Nothorhacopteris cf. N. argentinica, Aflébia de Nothorhacopteris cf. N. argentinica), Gimnospermópsidas (Noeggerathiopsis sp., Cordaicarpus zeilleri, Samaropsis itapevensis); Microflora: esporos lisos (Punctatisporites gretensis, P. lucidulus), esporos granulados (Granulatisporites austroamenicanus, Verrucosisporites morulatus, Dibolisporites disfacies, Raistrickia 
pinguis), esporos murornados (Ahrensisporites sp., Reticulatisporites sp., Murospora $\mathrm{sp}$.), esporos cingulizonados (Lundbladispora riobonitenses, Vallatisporites ciliaris), grãos de pólen monossacados radial (Plicatipollenites malabarensis, Plicatipollenites densus), grãos de pólen bilateral (Potonieisporites brasiliensis, Potonieisporites congoensis, Potonieisporites magnus, Divarisaccus stringoplicatus, Caheniasaccites flavatus) e prasinófitas (Tasmanites $\mathrm{sp}$ ).

Esses elementos são típicos de fácies hidro-higrófila e revelam pequeno transporte, contudo, aparecem depositados, junto a elementos mesofílicos num quadro regional glácio-flúvio-deltaico que, localmente, é mais sugestivo de ambiente lagunar/deltaico.

Dado o grande volume de fitomassa acumulada, que constitui a formação de camadas de carvão (autóctones ou levemente hipoautóctones) mais a relativa diversificação das espécies componentes da assembléia há uma forte sugestão para clima temperado provavelmente menos rigoroso de um interglacial. Essa evidência paleoclimática corrobora a posição paleolatidudinal dada por paleomagnetismo que coloca essa área entre 30 e $60^{\circ} \mathrm{S}$ no Carbonífero superior inicial.

A tafoflora Santa Marta é considerada neocarbonífera, de provável idade westfaliana, com base em seus elementos megaflorísticos comparáveis às associações da Zona NBG da Argentina e em seu conteúdo palinológico posicionada à Zona Biointervalo Ahrensisporites cristatus. Constitui parte integrante da tafoflora A, dentro da sucessão paleoflorística proposta por Rösler (1978) para a bacia do Paraná, correspondendo a uma flora gondvânica interglacial préglossopterídeas. 


\section{Abstract}

The Santa Marta Taphoflora, Guarizinho District, Municipality of Itapeva (SP), positioned in the median basal portion of the Itarare Subgroup, was firstly reported by J.H. Millan and coworkes in 1982. Between 1987 and 1995 Dr. J.H. Millan published a series of works/papers on its components.

Under the auspices of the Thematic Project FAPESP 97/03639-8, entitled: "Survey of paleofloristic composition and succession of Late Carboniferous-Early Permian (Tubarão Group) in the São Paulo State", the Santa Marta Taphoflora is revised in this Master of Science dissertation. The study gathers samples collected by Dr: Millan that now belong to the Museu Nacional - UFRJ Scientific Collection, and new material collected by the author and other researchers. The new material integrates the Scientific Collection of the Laboratory of Systematic Paleontology of the Instituto de Geociências of the University of São Paulo.

Abundant impressions of the taphoflora components are found at the entrance of an old coal-mine in the Santa Marta farm, preserved in a light brownish siltargillaceous material. Despite very fragmented, delicate stems, leaves and seeds are recognized and can be discriminated as follows: Macroflora: Sphenopsids (Sphenophyllum cf. S. churulianum, Sphenophyllum cf. rhodesii, Sphenophyllum sp. A., cf. Koretrophyllites sp., Paracalamites australis n. emend, Paracalamites levis .n. emen, Paracalamites sp.); Pteridophylles/Progymnospermopsids, (Botrychiopsis plantiana, cf. Eusphenopteris sp., Nothorhacopteris cf. N. argentinica, Aphlebie Nothorhacopteris cf. N. argentinica); Gymnospermopsids (Noeggerathiopsis sp., Cordaicarpus zeilleri, Samaropsis itapevensis); Microflora: smooth (?) spores (Punctatisporites gretensis, P. lucidulus), granulated spores, (Granulatisporites austroamericanus, Verrucosisporites morulatus, Dibolisporites disfacies, Raistrickia pinguis), murornated spores (Ahrensisporites sp., Reticulatisporites sp., Murospora $\mathrm{sp}$ ), cingulizonate spore (Lundbladispora riobonitenses, Vallatisporites ciliares), radial monossacate pollen grains (Plicatipollenites malabarensis, Plicatipollenites densus), bilateral (Potonieisporites brasiliensis, Potonieisporites congoensis, 
Potonieisporites magnus, Divarisaccus stringoplicatus, Caheniasaccites flavatus), prasinophytes (Tasmanites $\mathrm{sp}$ ).

This assemblage is typical of a hydro-hygrophilous facies, suggesting shortdistance transport. However, a lagunar/deltaic environment would seem more appropriate, considering that it appears together with mesophilous elements, reflecting regional glacio-fluviatile-deltaic conditions.

Taking into account the huge volume of accumulated phytomass that constitutes the coal measures (autochthonous and slightly hypoautochtonous) and the relatively wide diversification of species that compose the phytofossil assemblage, a temperate climate, probably less rigorous than an interglacial, is strongly favored.

This paleoclimatic evidence corroborates the paleolatitudinal position given by paleomagnetism, which places this area between $30^{\circ}$ and $60^{\circ} \mathrm{S}$, in the earlier Late Carboniferous.

The Santa Marta taphoflora is considered late Carboniferous, probably Westphalian in age, based on 1) its megafioristic elements that are comparable to the associations of the NBG Zone of Argentina, and 2) palynological content positioned at the Biointerval Zone Ahrensisporites cristatus. It integrates the taphoflora $A$ of the paleofloristic succession proposed by Rösler (1978) for the Paraná Basin, corresponding to a Pre-Glossopterids interglacial gondwanic flora. 


\section{Agradecimentos}

A autora deseja externar seus sinceros agradecimentos:

Ao Instituto de Geociências da Universidade de São Paulo, através do Programa de Pós-Graduação em Geologia Sedimentar, pela infraestrutura e liberação dos recursos necessários para o desenvolvimento de sua formação e deste trabalho;

Ao Instituto Geológico da Secretaria do Meio Ambiente do Estado de São Paulo, pelo apoio técnico e infraestrutura na preparação e obtenção de dados palinológicos;

À FAPESP Fundação de Amparo à Pesquisa do Estado de São Paulo, pela concessão de recursos financeiros para trabalhos de campo e melhoria de infraestrutura de laboratório, pela viabilização de novos equipamentos e instalações do laboratório de Paleobotânico do IGc/USP e possibilidades de visitas e estágios científicos na Universidade de Buenos Aires e na Universidade Federal do Rio de Janeiro, através do Projeto Temático 97/03639/8 "levantamento da composição e sucessão paleoflorísticas do Neocarbonífero-Eopermiano (Grupo Tubarão) no Estado de São Paulo".

Ao Conselho Nacional de Pesquisa (CNPQ) e à Coordenação de Aperfeiçoamento de Pessoal de Nível Superior (CAPES) pela concessão de bolsas de estudo;

À sua orientadora Dra . Mary E. C. Bernardes-de-Oliveira, pela preciosa orientação, amizade incondicional, carinho e eterna paciência em ensiná-la e mostrar-lhe sempre os melhores caminhos a percorrer;

Ao amigo Dr. Paulo Alves de Oliveira (IG-SEMA), pelo auxílio, amizade e estímulo em várias etapas do projeto;

À Dra . Maria da Saudade A.S. Maranhão (IG-SEMA), pela iniciação científica, ponto de partida de sua formação acadêmica que culminou com o desenvolvimento desse trabalho científico;

Ao amigo M.Sc. Jefferson Botelho de Oliveira (UniABC), por mostrar os caminhos da Paleontologia na realização de um sonho; 
Aos Drs. Setembrino Petri, Jeferson Prado, Thomas R. Fairchild pela formação acadêmica que ofereceram através do curso de Pós-Graduação

À Dr. Giana Guarda (IGc-USP), pelo auxílio na confecção do abstract.;

Ao Prof. Dr. Carlos L. Azcuy e a Dra. Mercedes Di Pasquo (Universidade de Buenos Aires), pelo estágio e auxílio no estudo de alguns grupos sistemáticos.

Ao Prof. Dr. Jean Broutin (Universidade de Paris VI), pelas valiosas sugestões em estudos taxonômicos de algumas formas e auxílio na documentação fotográfica.

Ao Dr. John Rigby (Universidade de Queensland), pelas preciosas sugestões;

Ao Prof. Dr. Paulo Roberto dos Santos (IG-USP), pelas preciosas sugestões em geologia do Subgrupo Itararé;

À Profa. Dra. Maria Judite Garcia (UnG-Universidade de Guarulhos), pela revisão em alguns capítulos;

À Prof ${ }^{a}$. Dra . Arlete Stcchi Zucchi (UniABC), pela revisão das referências bibliográficas.

À Prof ${ }^{a}$. Dra . Frésia Ricardi Branco (Universidade de Campinas-Unicamp), pelas sugestões durante o desenvolvimento da pesquisa, amizade e apoio.

A Dra. Diana Mussa (Museu Nacional da Universidade Federal do Rio de Janeiro), pela gentil colaboração e apoio técnico no acesso aos espécimes da coleção científica daquela entidadecoligidos e estudados pelo Dr. J. H. Millan.

Ao Dr. J. H. Millan, que mesmo que indiretamente, contribuiu de forma significativa ao desenvolvimento desse estudo, seja pela coleta de material seja pela localização do jazigo, observação e identificação cuidadosa da primeira coleção da tafoflora Santa Marta;

Aos amigos M.Sc. Edival Lopes da Silva (UNESP) e ao Motorista do IG-SEMA Márcio Ascarparo, pela colaboração nos trabalhos de campo e ao Dr. Roberto lannuzzi (UFRGS) pelo fornecimento de material para estudo palinológico;

Ao Sr. Noel Proença e a esposa Dona Sebastiana Proença (administradores da Fazenda Santa Marta, Itapeva, SP), pela amizade e acolhida durante os trabalhos de campo.

Às estagiárias: geóloga Monalisa Horvath (IGc-USP), e às biólogas Fernanda Vassoler e Juliana Marques da (UniABC), pelo processamento das amostras 
palinológicas e colaboração durante a preparação mecânica do material paleobotânico;

A seu irmão Marco Antonio Zampirolli, pelo apoio e ajuda na digitação das bibliografias;

A amiga Maria Cristina de Castro Fernandes, pela amizade e constante apoio. Aos amigos Dr. Pedro Antonio Federsoni Jr. (Instituto Biológico-SP), Dr ${ }^{2}$ Silvana Calixto (Instituto Biológico-SP), Silvana Dágostinho ilustradora botânica (Instituto Biológico-SP), a bióloga Naite Vitello (Instituto Biológico-SP), o biólogo Gilberto Giovanette Filho (Fundação Bradesco), ao Dr. Yanno Arnold Roze (American Museum Natural History); Artista Plástica Carmem Maria Vazques La Farina, a Dra. Rosemary Rohn (UNESP); a Geóloga Paula Garcia do Amaral (IGC-USP), a M.Sc. Fátima Rabelo Praxedes Leite (IGc-USP), a M.Sc. Ana Flora Mandarim-de-Lacerda (UFRJ), a geóloga Márcia Mica Saito (IGC-USP), ao M.Sc. George de Barros (IGCUSP), e as biólogas Fabiana Angélica Ferrari, Kelly Cristine Lopes (UNIABC), pelo apoio e companherismo.

Aos funcionários e amigos do IGc-USP da Pós-graduação, da Biblioteca, Gráfica e Secretarias, pelo apoio.

Aos sogros Jason Morais da Silva e Regina Morais da Silva, cunhados Rosana Morais da Silva, Elizabete da Silva Zampirolli e Samuel, pelo constante apoio;

Aos queridos pais José Antonio Zampirolli e Odécia C. Zampirolli, pelo apoio e estímulos constantes, pela cooperação nos momentos difíceis, o seu amor e a sincera e profunda gratidão.

Especialmente, ao seu esposo Ronaldo Morais da Silva, pelo companheirismo e compreensão nos momentos mais difíceis, além de suas ricas sugestões e o seu eterno amor. E a sua filha Ana Luiza, razão e força para continuar a seguir sempre em frente, o seu mais profundo amor;

E principalmente, a Deus por colocar sempre em seu caminho, pessoas certas e amigas, e dar-lhe forças, saúde e inspiração para realizar todo esse trabalho. 
Resumo.

ÍNDICE GERAL

Abstract. iii

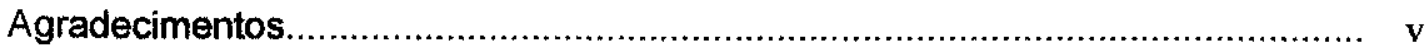

Índice Geral........................................................................................ viii

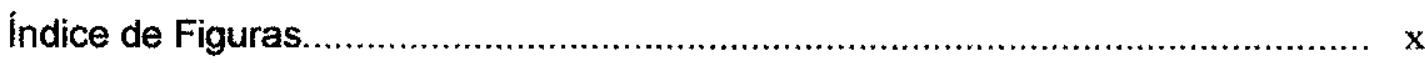

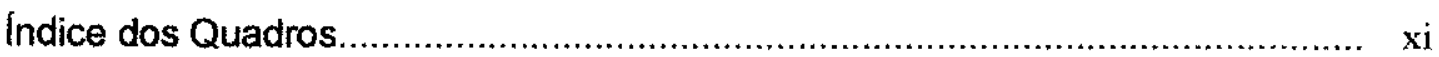

CAPITULO I. ASPECTOS GERAIS

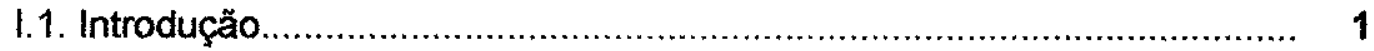

I.2. Objetivos e Justificativas ................................................................. 6

CAPITULO II. ARCABOUÇO ESTRATIGRÁFICO REGIONAL

II.1. Geologia Regional................................................................. 7

CAPITULO III. MATERIAL E MÉTODOS

III.1. Área de Procedência do Material Estudado..................................... 12

111.2. Características do Material Estudado............................................... 15

III.3. Métodos de Estudo ................................................................. 16

III.3.1. De Campo............................................................................. 16

III.3.2. De Laboratório .................................................................... 17

III.2.1. Para Macrofitofósseis........................................................... 17

III.2.2. Para Microfósseis............................................................... 18

CAPITULO IV. PESQUISAS PALEOBOtÂNICAS PRÉVIAS DA TAFOFLORA ESTUDADA

IV.1. Pesquisas Prévias.

CAPITULOO V. SISTEMÁTICA PALEOBOTÂNICA

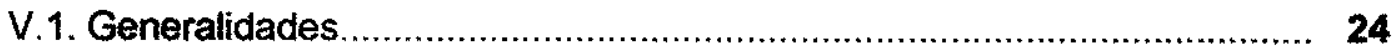

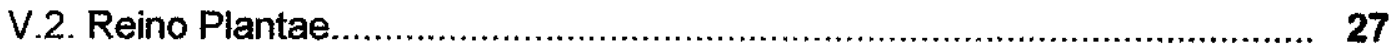

Divisão Trachaeophyta............................................................. 27

Classe Sphenopsida............................................................ 27

V.2.1. Ordem Sphenophyllales.................................................... 27

V.2.2. Ordem Equisetales........................................................... 36

V.3. Classe Gymnospermopsida.................................................. $\quad 50$

V.3.1. Ordem Pteridospermales..................................................... 51

V.3.2. Ordem Cordaitales.............................................................. 73

V.4. Semina Incertae Sedis/Dispersae ................................................ 74

CAPITULO VI. SISTEMÁTICA DOS MICROFITOFÓSSEIS

VI.1. Palinobioestratigrafia no Subgrupo Itararé..................................... 79 
VI.2. Generalidades................................................................... 84

VI.3. Listagem Sistemática............................................................... 85

CAPITULO VII. TRATAMENTO E INTERPRETAÇÃO DE DADOS

VII.A- Dados Macroflorísticos................................................................. 90

VIl.A1. Aspectos do Ambiente tafonômico.................................................. 90

VII.A2. Interpretações Paleoecológicas.............................................. 91

VIIA.3. Interpretações Paleofitogeográficas e Paleoclimáticas................. 96

VII. B- Dados Microflorísticos ............................................................ 100

VIIB.1. Afinidades Botânicas e Ecológicas........................................ 100

VIIB.2. Interpretações Paleoecológicas ............................................... 101

VII.C- Dados Bio e Cronoestratigráficos ........................................... 102

CAPITULO VIII. CONCLUSÕES FINAIS

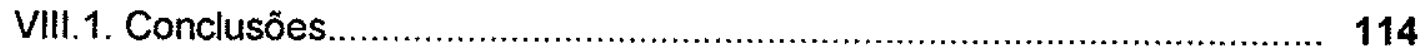

CAPÍTULO IX. REFERÊNCIAS BIBLIOGRÁFICAS

XI.1. REFERENCIAS BIBLIOGRÁFICAS ............................................ 118

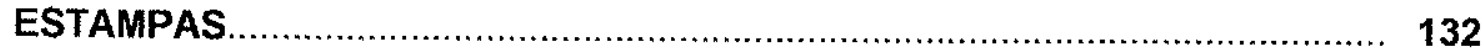




\section{INDICES DE FIGURAS}

Figura 1.1. Mapa geológico do Estado de São Paulo com as localidades estudadas no 2 Projeto Temático FAPESP 97/03639-8 modificado (IPT, 1981).

Figura I. 2. Diagrama Cronoestratigráfico do Grupo Tubarão com o posicionamento bioestratigráfico das principais ocorrências fitofossiliferas do Subgrupo Itararé, ressaltando-se em amarelo a coluna referente ao Estado de São Paulo. (modificado de Petri \& Souza, 1993).

Figura II.1. Mapa e perfil (A-B) geológicos da área Buri-Itapeva, extraído de Cabral Jr. \& 8 Motta (1985).

Figura II.2. Predomínios faciológicos, modificado de Cabral Jr. \& Motta (1985).

Figura III.1. Mapa geológico e de localização do afloramento fitofossilífero Fazenda Santa Marta, região de Itapeva (SP). (modificado de Silva, 1994)

Figura III.2. $\quad$ Fazenda Santa Marta-Seção colunar na entrada da mina de carvão

Figura VI.1. Quantificação dos morfogrupos das lâminas IG-P 286 A, B e C da fazenda Santa Marta, Itapeva (SP). 


\section{INDICE DE QUADROS}

Quadro 1.1. Palinozoneamento do Subgrupo Itararé e Formação Rio Bonito, proposto 5 por Souza (2000, inédito)

Quadro IV.1. Síntese do histórico do desenvolvimento das pesquisas paleobotânica da 23 Fazenda Santa Marta.

Quadro V.1. Lista dos componentes da Fazenda Santa Marta conhecido até 1995 e daqueles registrados após a revisão nesta dissertação.

Quadro V.2. Quadro de morfometria das espécies de Paracalamites.

Quadro VI.1. Distribuição geral de todas as espécies estudadas nas biozonas propostas 80 do Subgrupo Itararé (este trabalho) e na Formação Rio Bonito modificado de Souza (2000, inédito).

Quadro VI.2. Situação e Correlação das propostas palinoboestratigráficas para o Paleozóico superior Bacia do Paraná, modificado de Souza (2000, inédito).

Quadro VI.3. Afinidades Botânicas da assembléia palinológica da tafoflora Santa Marta.

Quadro VII.1. Comunidades carboniferas conforme o ambiente de vida.

Quadro VII.2. Distribuição dos hábitos dos fitofósseis da tafoflora Santa Marta. Itararé.

Quadro VII.3. Distribuição Estratigráfica dos taxas da tafoflora Santa Marta no Subgrupo

Quadro VII. 4. Distribuição Estratigráfica do gênero Sphenophyllum.

Quadro VH.5. Distribuição Estratigráfica da espécie Botrychiopsis plantiana

Quadro VII. 6. Distribuição Estratigráfica da espécie Nothorhacopteris argentinica.

Quadro VII.7. Distribuição Estratigráfica dos macrofitofósseis as tafoflora Santa Marta.

Quadro VII.8. Migração florística na América do Sul durante o Carbonífero: Implicações phytogeográficas e bioestratigráficas-modificado de Iannuzzi \& Rösler (2000). 
CAPÍTULO I 


\section{CAPÍTULO I. ASPECTOS GERAIS}

\subsection{Introdução}

O Subgrupo Itararé, de idade permo-carbonífera, constitui a unidade litoestratigráfica basal do Grupo Tubarão (Rocha-Campos 1967), da bacia do Paraná, compreendendo litologias de origem glácio-marinha, flúvio-deltaica, gláciolacustre. Possui um documentário paleontológico relativamente diversificado, incluíndo: micro- e macrofósseis vegetais, foraminíferos arenosos, espículas de esponjas, braquiópodes, escolecodontes, icnofósseis (tubos de vermes, pistas de artrópodes e de outros organismos não identificados), bivalves, gastrópodes, ostracodes, euripterídeos, equinodermes, peixes e possíveis anfíbios, conforme ressaltaram Petri \& Souza (1993).

Observações sobre ocorrências de carvões no Subgrupo Itararé, do Estado de São Paulo, têm sido feitas desde há muito. Moraes Rego (1934) referiu-se a três bacias hulheíferas desse Subgrupo, em território paulista, como: a bacia de Paranapanema, que envolveria os carvões de Buri e de Itapeva (respectivamente, de Campina de Enxovia e da Fazenda Santa Cruz); a bacia de Tatuí, que envolveria os carvões de Cerquilho e Cesário Lange (afloramentos do Ribeirão da Onça, Cerquilho e Barra do Capivari) e a bacia de Jacuba, que compreenderia os carvões de Monte Mor (então denominado afloramento do município de Campinas, próximo à estação Rebouças).

As ocorrências fitofossilíferas do Subgrupo Itararé, no Estado de São Paulo, apesar de terem sido objeto de estudo desde os anos 70, sobretudo através do Projeto "Carvões do Estado de São Paulo "desenvolvido pelo Dr. José Henrique Millan, então pesquisador do Museu Nacional da Universidade Federal do Rio de Janeiro, apresentam ainda raras ocorrências de macrofitofósseis. Seu conhecimento relativamente pequeno quanto à composição taxonômica e à posição estratigráfica, embora seja a seqüência mais espessa aí do que no restante da bacia, carecem de estudos taxonômicos e fitoestratigráficos atualizados, bem como de correlações melhor estabelecidas. Vide Fig.l.1. 


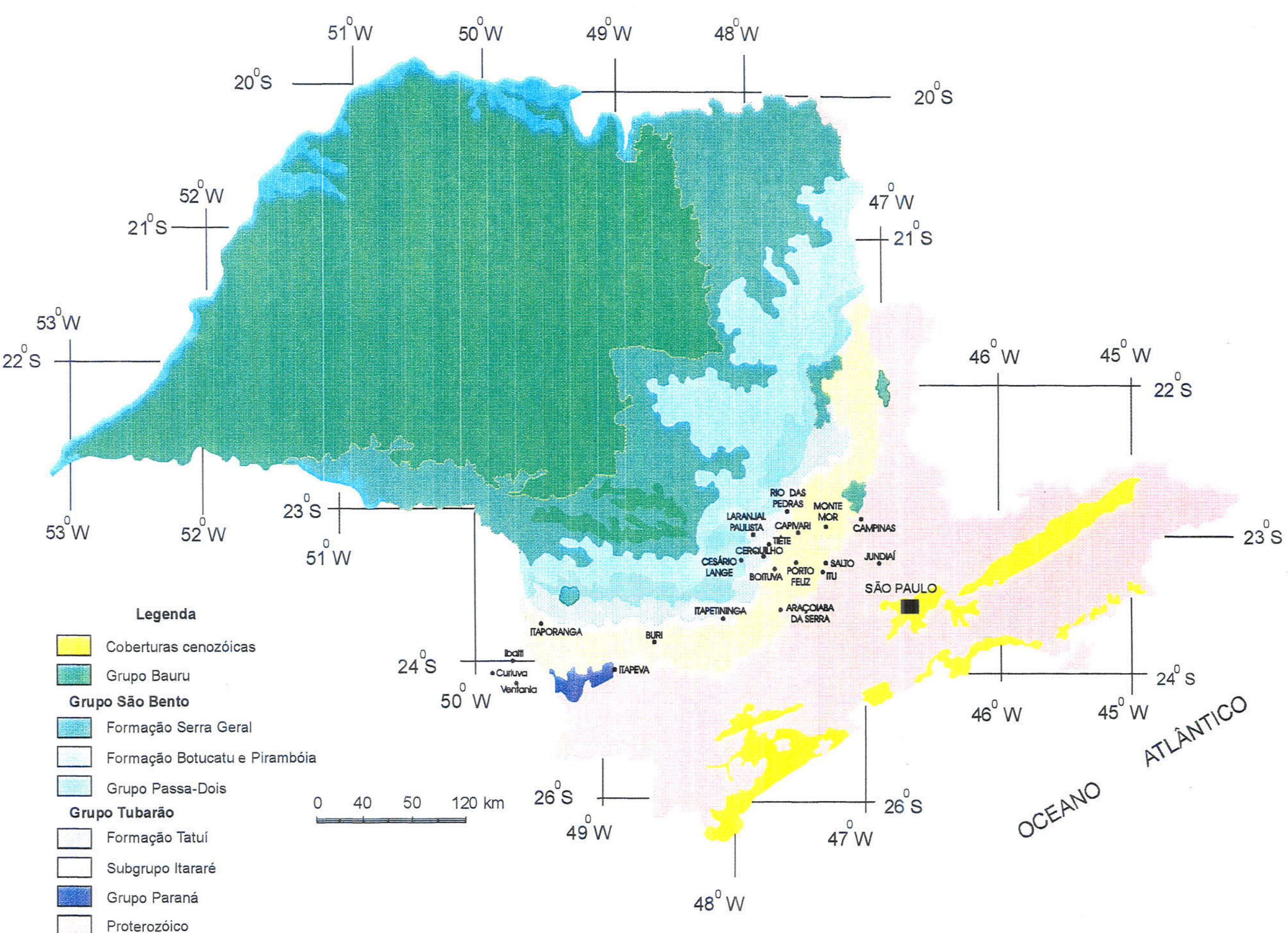

Fig.l. 1: Mapa geológico do Estado de São Paulo com as localidades estudadas no Projeto FAPESP 97/03639-8 (modificado de IPT, 1981). 
Tentativas de interpretação do posicionamento estratigráfico das tafofloras neopaleozóicas da bacia do Paraná vêm sendo feitas desde algum tempo. Entre essas se citam as de Barbosa \& Almeida (1949), Dolianiti (1952), Barbosa (1958), Rigby (1972), Saad (1977) e RochamCampos \& Rösler (1978). Zoneamentos fitoestratigráficos foram também tentados com base em dados macro- e microflorísticos, entre os quais poderiam ser citados, principalmente no que se refere ao Estado de São Paulo, Daemon \& Quadros (1970), Rösler (1978), Saad (1977), Arai (1980), Sundaram (1980; 1987), Millan (1987a). A última sintese dos conhecimentos bioestratigráficos do Subgrupo Itararé, na bacia do Paraná, envolvendo os diferentes grupos fósseis ocorrentes, foi apresentada por Petri \& Souza (1993), vide Fig.l.2. Nesse Estado, um palinozoneamento para o Subgrupo Itararé foi, recentemente, proposto por Souza (2000, inédito, Quadro 1.1.), compreendendo de baixo para cima duas zonas (Ahrensisporites cristatus e Potonieisporites neglectus) e uma subzona (Protohaploxypinus goraiensis).

O estudo tafofiorístico de seqüências carboníferas do Subgrupo Itararé, na fazenda Santa Marta (Itapeva, SP), tema dessa dissertação de mestrado, é parte integrante do Projeto Temático FAPESP-n`97/03639-8, intitulado: "Levantamento da composição e sucessão paleofiorísticas do Neocarbonífero-Eopermiano (Grupo Tubarão), no Estado de São Paulo".

Nesse contexto, o estudo da tafoflora Santa Marta tem um caráter de complementação e revisão taxonômica das formas de macrofitofósseis estudadas por Millan (de 1987 a 1995), com base em novas coletas e também no exame das formas já estudadas, além da obtenção inédita de dados palinológicos das camadas portadoras e associadas. Assim, visa o refinamento de dados sistemáticos e bioestratigráficos, para definir melhor a paleoflora interglacial neopaleozóica da região, bem como interpretar seu significado paleoecológico, bioestratigráfico e cronológico, e estabelecer correlações mais seguras em nivel regional e gondvânico. 


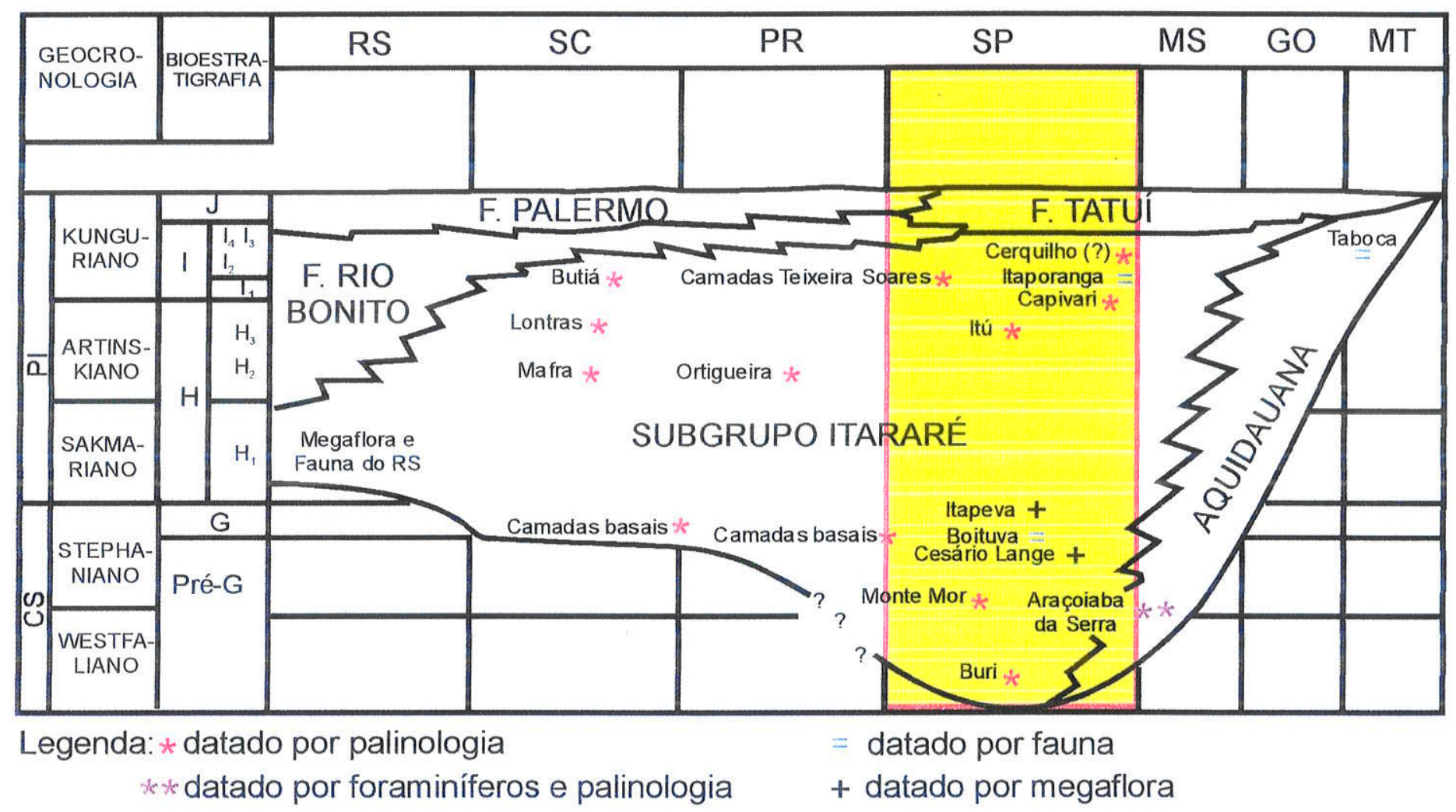

Fig. I.2 - Diagrama cronoestratigráfico do Grupo Tubarão, com o posicionamento bioestratigráfico das principais ocorrências fossilíferas do Subgrupo Itararé, ressaltando-se em amarelo a coluna referente ao Estado de São Paulo (modificado de Petri \& Souza, 1993). 


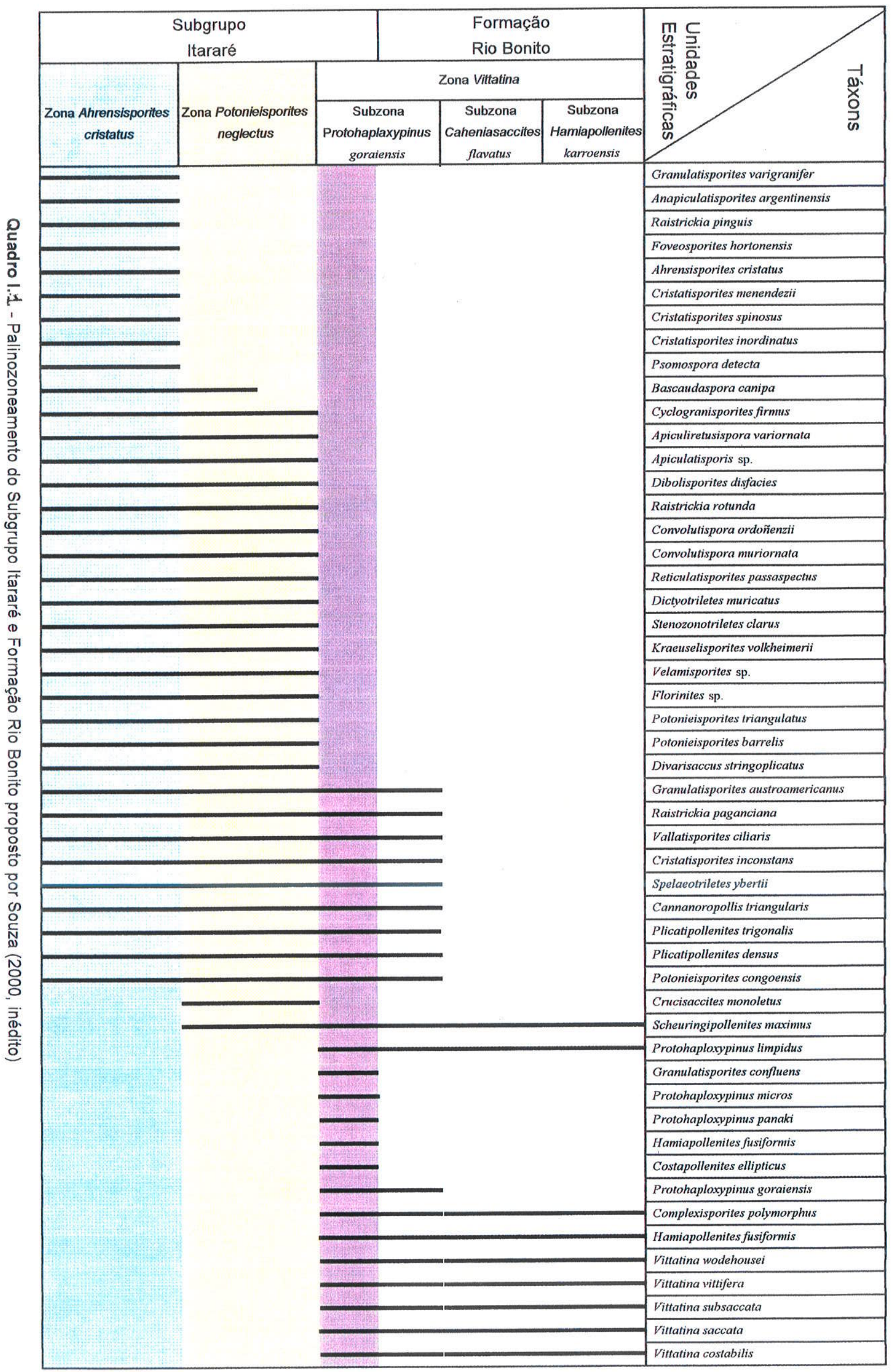




\subsection{Objetivos e Justificativas}

O presente estudo fundamenta-se na revisão dos dados macrofitofossiliferos já obtidos para a região de ltapeva, SP, e no estudo sistemático detalhado do material paleobotânico e palinológico obtido através de novas coletas tendo por objetivo chegar-se:

-a um maior conhecimento da composição tafoflorística (macro e micro) do jazido fossilífero, uma vez que essa tafoflora foi, apenas parcialmente, descrita por Millan (1987a, 1989 e 1991a e b);

-a uma contribuição, ainda que pontual, mais segura no estabelecimento da sucessão paleoflorística regional;

-ao conhecimento do conteúdo palinológico dos sedimentos portadores desses macrofitofósseis, até agora desconhecido. Seu estudo possibilitaria melhores correlações estratigráficas dentro da bacia do Paraná e para além de seus limites;

-a uma determinação da idade mais precisa dos sedimentos envolvidos e da própria tafoflora ;

-e a uma contribuição para interpretações paleoecológicas, paleogeográficas, paleoambientais e paleoclimáticas regionais a partir dos componentes tafoflorísticos estudados. 
CAPÍTULO II 


\section{CAPITULO II ARCABOUÇO ESTRATIGRÁFICO REGIONAL}

\section{II.1. Geologia Regional}

A região de Buri e Itapeva no Sudoeste do Estado de São Paulo, situa-se ao norte do arco de Ponta Grossa, próxima ao alinhamento de Guapiara. É coberta por sedimentos do Subgrupo Itararé que se assentam, ao sul, diretamente sobre o embasamento cristalino ou, fora da área, sobre rochas devonianas, e ao norte são recobertos pelos da Formação Tatuí. Conforme Cabral Jr. \& Motta (1985), tectonicamente, a área mostra um sistema de falhamentos escalonados do tipo "Horst" e "Graben", com duas direções preferenciais NW-SE e NE-SW com rejeitos variando até mais de duas centenas de metros, Mapa e Perfil Fig.II.1.

O Subgrupo Itararé, na região, é caracterizado por ampla variedade litológica e constitui-se por arenitos, em geral cinza-esbranquiçados, de granulometria variada, desde muito finos a conglomeráticos. Ocorrem ainda diamictitos, ritmitos, siltitos, folhelhos, argilitos maciços incluindo-se os níveis de carvão.

Com base na caracterização faciológica dos pacotes sedimentares, foram reconhecidas quatro unidades conforme Cabral Jr. \& Motta (1985). Estas unidades podem ser vistas na Fig.ll.2 e são assim descritas:

Unidade A- basal, constituída de pelitos e secundariamente por arenitosinterpretados como fácies de frente deltaica e prodelta.

Unidade B-imediatamente superior, com 50m de espessura, apresentando mais de $100 \mathrm{~m}$ excepcionalmente. Compõe-se essencialmente de arenitos finos a médios, com lentes de conglomerados, siltitos e camadas de carvão. Estratificações cruzadas ocorrem como estruturas sedimentares mais comuns nos arenitos, variando de grande a médio porte na base, e diminuindo para o topo até microcruzadas, onde é comum a presença de bioturbação por raízes. Essa associação faciológica foi interpretada como depositada em ambiente de planície deltaica, com acúmulo de material lenhoso e macrofitofósseis. 


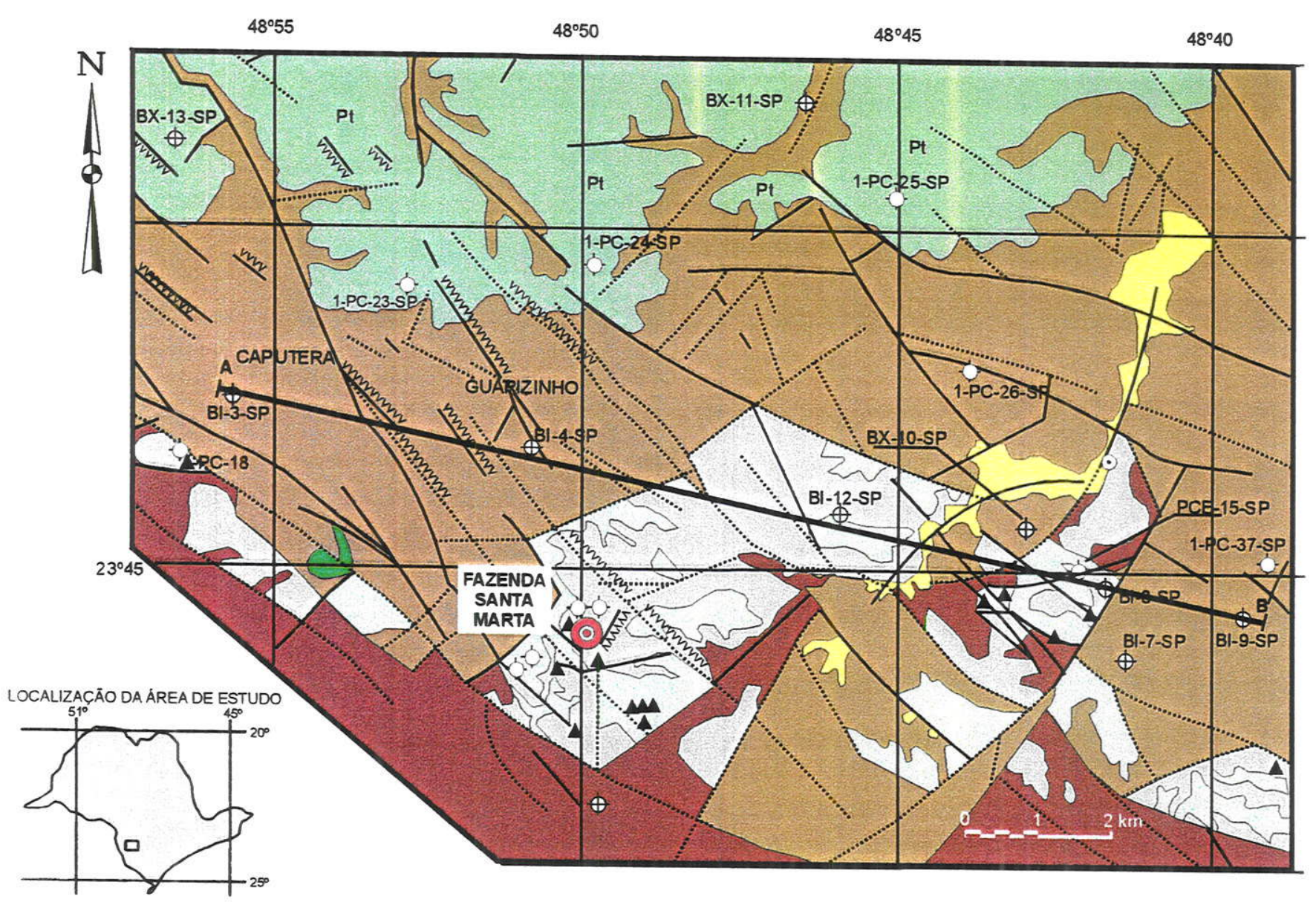

LEGENDA

UNIDADES LITOESTRATIGRÁFICAS

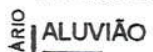

SEDIMENTOS INCONSOLIDADOS

Oे FORMAÇÃO TATUI

SILTITOS E LAMITOS ARROXEADOS E ESVERDEADOS

FORMAÇĀO ITARARÉ

DIAMICTITOS, ARENITOS E SEDIMENTOS FINOS-

ABRANGENDO O TOPO DA UNIDADE CE A UNIDADE D

PREDOMINIO DE SEDIMENTOS FINOS - ABRANGE A

BASE DA UNIDADE C

UNIDADE B - PREDOMINIODE ARENITS - SUBORDINADAMENTE OCORREM CAMADAS DE CARVĀO

UNIDADE A - PREDOMINIO DE SEDIMENTOS FINOS

CONVENÇŌES GEOLÓGICAS

CONTATO DEFINIDO wm DIQUE DE DIABÁsIO

contato INFERIDo $\circlearrowright$ SILlde diabásio

FALHADEFINIDA 7 DEPÓSITO DE CARVĀO DE BURI

FALHAINFERIDA OCORRÊNCIA DE CARVĀO

- FAZENDA SANTAMARTA

SONDAGENS

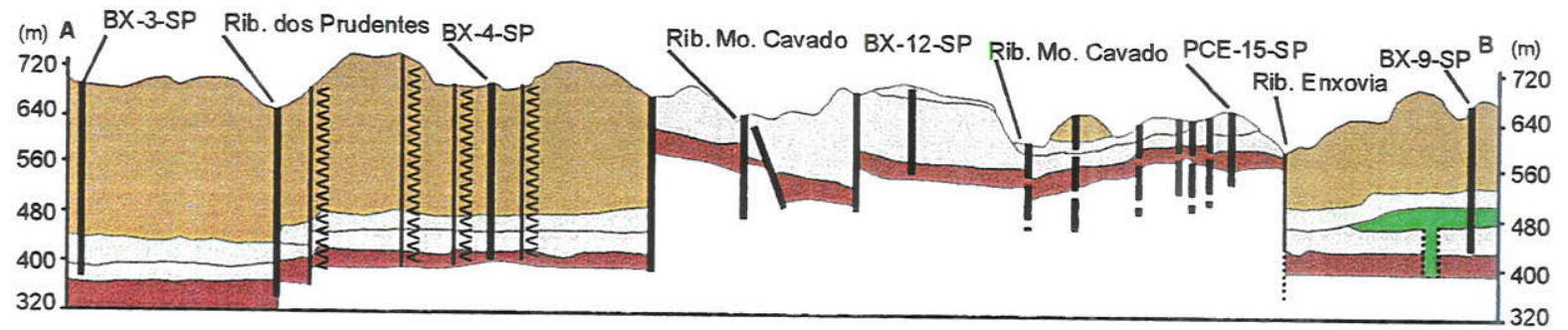

๑ PERFURAÇÃo EXECUTADA PELOIPT

$\Rightarrow$ PERFURAÇÃO EXECUTADA PELA CPRM

Fig. II. 1 - Mapa e perfil (A-B) geológicos da área Buri-Itapeva (extraído de Cabral Jr. \& Motta, 1985) 

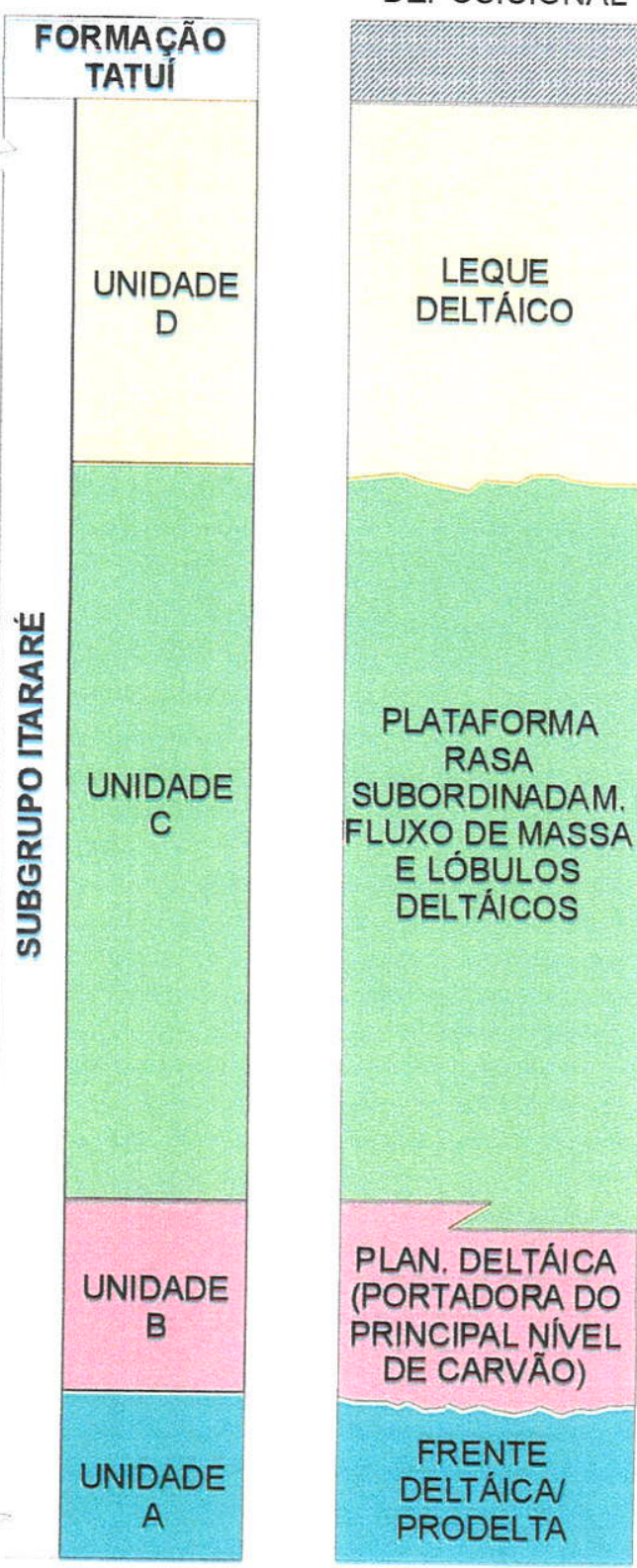

\section{$\cdots$ CONTATO EROSIONAL $-\quad$ CONTATO TRANSICIONAL}

(m)

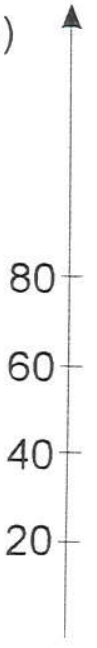

Fig. II.2 - Predomínios Faciológicos (modificado de Cabral Jr. \& Motta, 1985). 
Unidade C- compõe-se de siltitos e arenitos finos, acinzentados, às vezes interlaminando-se e intensamente bioturbados. Estratificações microcruzadas, laminações onduladas e do tipo "flaser", sugerem um ambiente de frente deltaica passando a ambiente de plataforma rasa. Trata-se de um ciclo transgressivo sobre os sedimentos de planície deltáica da Unidade $B$, depositado em ambientes frentedeltaica com pequenos acúmulos de carvão interglacial.

Unidade D- inclui, predominantemente, arenito e diamictitos. Uma assembléia basal é constituída pelos arenitos de granulometria fina a grossa, de seleção variada, às vezes feldspáticos, com níveis conglomeráticos contendo fragmentos carbonosos. A outra assembléia litológica abrange arenitos homogêneos, diamictitos e camadas pelíticas.

Apesar da relativa complexidade faciológica desta unidade, a relação da fácies continental truncando diretamente seqüências marinhas permite associar todo - pacote sedimentar a um ambiente deposicional marinho costeiro, do tipo leque deltaico. Vide Fig.II.1.

A sedimentação na região de Buri-ltapeva (SP), conforme Silva (1994), é representada por fácies costeiras de ressedimentação depositadas em um complexo deltaico, assim como por fácies de ressedimentação depositadas em leques submarinos em condições plataformais de um mar epicontinental. As fácies costeiras representam fases construtivas, enquanto que as fácies de ressedimentação correspondem às fases destrutivas do episódio deposicional. Essa sedimentação é, regionalmente, influenciada por um tectonismo ativo, e pela ingressão marinha, que se inicia com a discordância Itararé-Ponta Grossa e culminará com a transgressão Palermo, associada à glaciação gondvânica. A sedimentação nesta área exibe um caráter cíclico, refletindo uma sedimentação por pulsos proporcionados pelos avanços e recúos de geleiras.

Os sedimentos do Subgrupo Itararé na área de Buri-Itapeva foram considerados por Ciantelli Jr. et al. (1983), Cabral Jr. \& Motta (1985) e Silva (1994) como posicionados na porção mediano-superior dessa unidade. Contudo, essa interpretação não é corroborada pelos dados advindos da palinologia do carvão de 
Buri, adjacente a Itapeva, os quais são sugestivos de niveis bioestratigráficos mais basais no Subgrupo (Souza 1997; Souza et al. 1990, 1993a).

A tafoflora Santa Marta, ora estudada, estaria posicionada, estratigraficamente, na unidade B de Cabral Jr. \& Motta (1985), aflorante na área do "horst", localizada ao sul do perfil $A B$ traçado por aqueles autores e representado na Fig.ll.1. (conforme Fig.1. de Cabral Jr. \& Motta 1985). Sua localização geográfica e detalhamento geológico poderão ser vistos no Cap.III. 
CAPÍTULO III 


\section{CAPITULO III. MATERIAL E MÉTODOS}

\section{III.1. Área de Procedência do Material Estudado}

No bairro Guarizinho, área norte do Município de Itapeva (Vide Fig.ll.1), ocorre uma tafoflora de fundamental importância na caracterização da sucessão paleoflorística Permo-Carbonífera do Estado de São Paulo .

Os fitofósseis constituintes da tafoflora, aqui estudados, são provenientes do paredão lateral esquerdo à entrada da antiga mina abandonada de carvão (Est. 13, figs.1-3) da fazenda Santa Marta, situada naquele bairro, distando, aproximadamente, $30 \mathrm{Km}$ da cidade de Itapeva, na direção norte.

Observando o perfil geológico aí levantado (Fig.ll.2.), o afloramento apresenta uma seqüência de litologias predominantemente, detríticas finas dispostas da seguinte forma:

Desde a base do paredão até $1,90 \mathrm{~m}$ de altura, tem-se uma alternância de camadas de ritmito (constituído de arenito fino e argila carbonosa) com camadas de siltito argiloso cinza-escuro, em espessuras variáveis, recobertas por uma crosta limonítica secundária.

A seguir, para o topo, após uma camada de mais ou menos $30 \mathrm{~cm}$ de argila vermelha, o pacote torna-se mais francamente arenoso de gradação fina a média e aspecto variegado. O nível fitofossilífero corresponde ao da argila vermelha, na porção médio-superior do afloramento (Vide Est.14, figs. 1 a 3). Essas litologias e estruturas rítmicas parecem ser parecidas com a descrição da unidade " $\mathrm{B}$ " de Cabral Jr. \& Motta (1985) para as quais atribuem ambiente de deposição de planície deltaica, com acúmulo de material lenhoso e macrofitofósseis. 


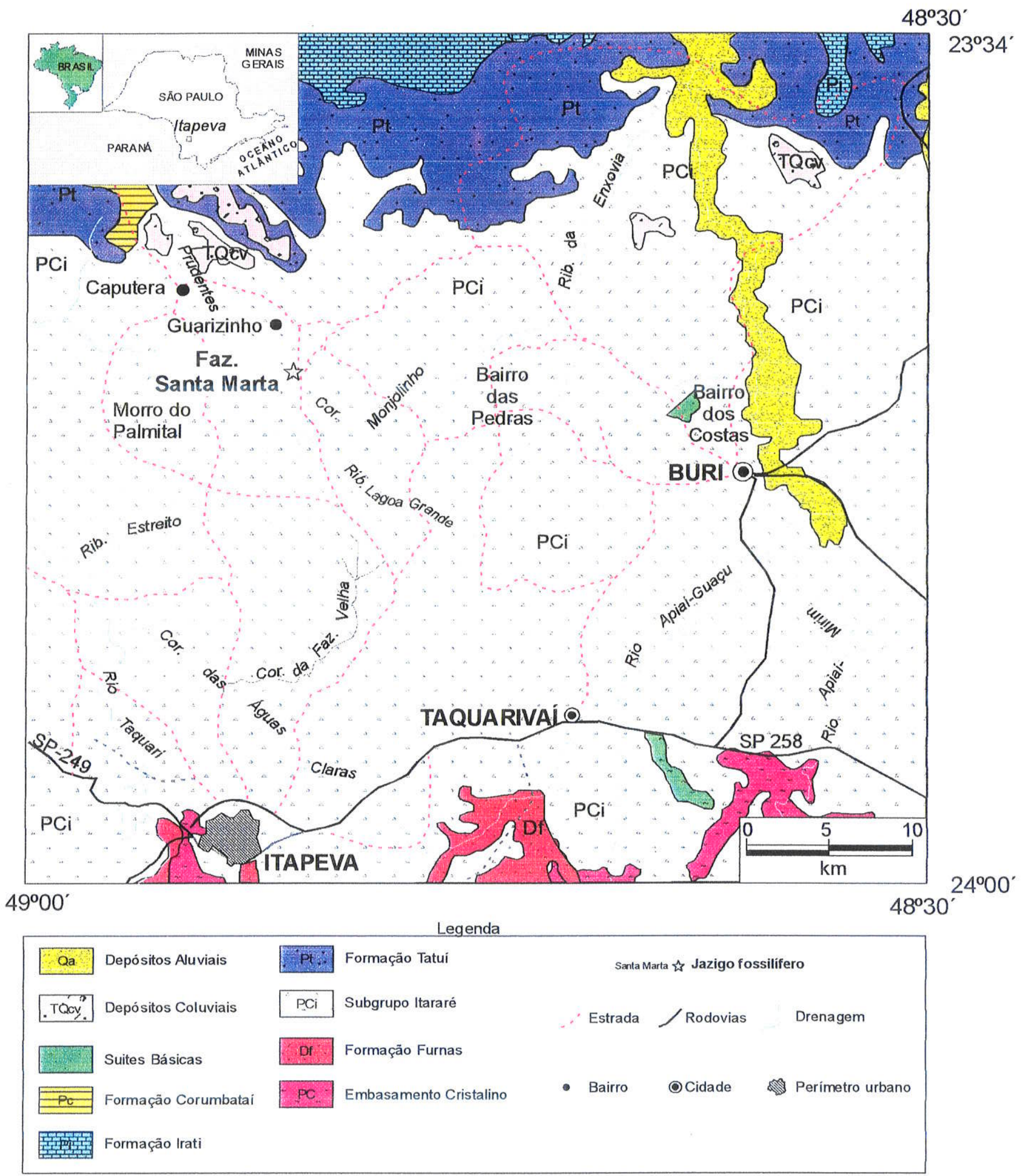

Fig. III.1: Mapa geológico e de localização do afloramento fitofossilífero Fazenda Santa Marta, região de Itapeva (SP) (Modificado de Silva, 1994). 


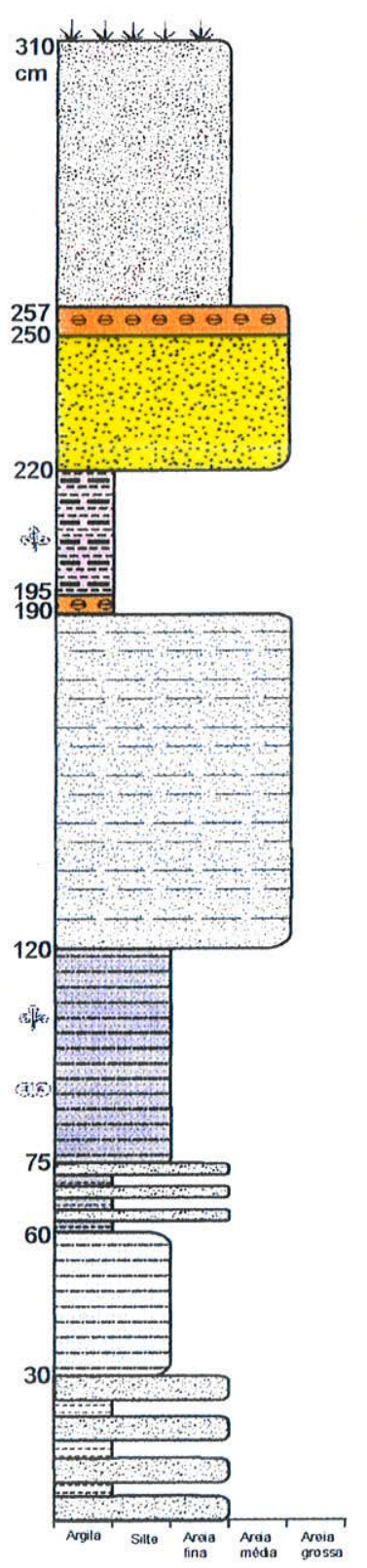

Arenito fino arcoseano, friável, amarelo claro a variegado, maciço.

Limonita

Arenito médio variegado, friável.

Argila avermelhada, passando a variegada (creme-ferruginosa a avermelhada) contendo fitofósseis

Limonita

Ritmito de lâminas finas de arenito médio cinza e de material carbonoso, intercaladas a cada $0,5 \mathrm{~cm}$ aproximadamente.

Siltito argiloso, cinza-escuro, maciço, com lâminas finas arenosas. Nivel com possiveis licófitas e sementes.

Ritmito de lâminas de argila cinza-escura e de arenito fino cinza claro.

Siltito argiloso cinza, carbonoso com lâminas de $1,5 \mathrm{~cm}$ de arenito a $5 \mathrm{~cm}$ do topo.

Ritmito de arenito fino, cinza com argila carbonosa e concreçöes limoníticas.

- Fitofósseis - Esporos

Fig. III.2: Fazenda Santa Marta - Seção colunar na entrada da mina de canão. 


\section{III.2. Características do Material Estudado}

Os fitofósseis desse sítio paleontológico ocorrem como impressões, abundantemente acumuladas, superpondo-se umas às outras, em matriz sílticoargilosa, marrom-clara a avermelhada, apresentando pouco contraste de cor com a rocha-matriz.

Esses fitofósseis tratam-se de formas delicadas e muito fragmentadas, em sua maioria higrófilas, depositadas sem uma direção preferencial, sugerindo pequeno transporte mas suficiente para fragmentá-las muito, dada sua natureza frágil. Entre as formas mais comuns destacam-se: Botrychiopsis, Notorhacopteris, Paracalamites, Sphenophyllum, Koretrophyllites, Cordaites, Cordaicarpus, caules e folhas indeterminados.

O material estudado compreende alguns espécimes que fazem parte da Coleção Científica do Laboratório de Paleontologia Sistemática do IGc/USP, estando depositados sob os números GP/3T-2260, 2266, 2267, 2264, 2265 e GP/3E- 8912A e A', 8912D e d', 8896, 8814, 8917, 8944, 8952A, 8953A, 9027B, 8928A e 8928B, enquanto, outros fazem parte da Coleção Científica do Museu Nacional UFRJ onde estão catalogados sob os números MN/UFRJ-1962Pb, 1963PbA e B, 1961PbA e B, $1970 \mathrm{~Pb}, 1977 \mathrm{~Pb}, 1979 \mathrm{~Pb}, 1981 \mathrm{PbA}, 1981 \mathrm{PbB}, 1989 \mathrm{~Pb}, 1991 \mathrm{PbA}, 1843 \mathrm{~Pb}$, $1845 \mathrm{PbA}$ e $\mathrm{B}, 1847 \mathrm{~Pb}, 1848 \mathrm{~Pb}, 1850 \mathrm{~Pb}, 1852 \mathrm{~Pb}, 1842 \mathrm{~Pb}, 1844 \mathrm{~Pb}, 1846 \mathrm{~Pb}$, $1849 \mathrm{~Pb}, 1851 \mathrm{~Pb}, 1853 \mathrm{~Pb}, 1854 \mathrm{~Pb}, 1855 \mathrm{~Pb}, 1967 \mathrm{PbA}, \mathrm{B}$ e C, 1965Pb e 1969Pb.

Os da primeira coleção foram coligidos pela autora e outros pesquisadores.

Algumas amostras de superfície, coletadas no afloramento da fazenda Santa Marta evidenciaram potencialidade palinológica confirmada por sua preparação e estudo.

As lâminas palinológicas estão depositadas no Instituto Geológico da Secretaria do Meio Ambiente do Estado de São Paulo, com codificação entre: 283A, $283 \mathrm{~B}$ e $283 \mathrm{C}$. 


\section{III.3. Métodos de Estudo}

\section{III.3.1. De Campo}

Para realizar o estudo proposto foram efetuadas quatro viagens de campo à região de Itapeva $(\mathrm{SP})$.

Nessas viagens teve-se por objetivo a coleta sistemática de amostras na entrada da mina abandonada de carvão da Fazenda Santa Marta e à margem do córrego na Fazenda Morro Alegre, a localização do afloramento no mapa e a distância da cidade de Itapeva até a Fazenda Santa Marta, observações geológicas e observação da seqüência sedimentar local.

Quanto à coleta de amostras, cerca de 200 amostras foram coligidas para o estudo macrofitológicos e palinológicos, na entrada da mina abandonada de carvão, na Fazenda Santa Marta, de onde foram retirados grandes blocos das camadas fossilíferas na tentativa de se extrair melhores exemplares para o estudo macrofitológicos e da litologia escura para o estudo palinológico.

No afloramento à margem de um córrego na Fazenda Morro Alegre, obtiveram-se das amostras de carvão, algumas impressões de caule possivelmente licofíticos, folhas e sementes indeterminadas, e também, foram extraídas amostras de carvão para análise palinológica. Contudo, o estudo dessa ocorrência foi abandonado por não ter sido encontrado material em estado razoável de preservação para o estudo, nem resultados palinológicos satisfatórios.

Um reconhecimento da geologia foi feito percorrendo as rodovias SP-258 (Capão Bonito-Taquarivaí-Itapeva-Itararé), SP-249 (Itapeva-Itaberá) e rodovia Campina de Monte Alegre-Buri. Verificou-se que, como foi registrado em Silva (1994), na área de coleta dos fósseis (Fazenda Santa Marta e Fazenda Morro Alegre) as exposições de afloramentos são raras e ocorrem melhor ao longo de drenagens. A fácies arenosa do Subgrupo Itararé predomina amplamente, seguida da fácies pelíticas e carbonosas, principalmente na área correspondente ao "Horst" de Cabral Jr. \& Motta (1985). 
Apesar das dificuldades de acesso ao afloramento (situado em área alagada) dentro da mata de galeria de um córrego, foi observada a seqüência sedimentar no local do jazigo fossilifero da Fazenda Santa Marta. Ai verificou-se que há duas camadas fossilíferas síltico-argilosa, carbonosas, mais ou menos oxidadas, separadas por uma camada de arenito grosso. As coletas foram realizadas em ambas as camadas fitofossilíferas.

\section{III.3.2. De Laboratório}

III.3.2.1. Para macrofitofósseis na forma de impressões e contraimpressões.

Após coleta de campo com localização da camada fossilífera em perfil geológico, o material foi trazido para o laboratório de Paleobotânica do IGc/USP.

Foi deixado secar lentamente por um prolongado tempo, uma vez que se tratava de material muito friável e úmido. Durante o período, houve trocas regulares dos jornais que os envolviam para evitar que mofassem. Após a secagem do material realizou-se as seguintes etapas:

Preparação mecânica das amostras desbastando-as e descobrindo-as com pequenas talhadeiras, marteletes e vibro-graver;

Seleção dos melhores exemplares usando como critério o grau de preservação, de nervação, ápice, base ou pecíolos foliares; de estriações caulinares do corpo central e asas de sementes

Numeração - foi estabelecida segundo as normas da coleção de material de estudo do Laboratório de Paleontologia Sistemática do Departamento Geologia Sedimentar e Ambiental do IGc/USP,

Listagem preliminar agrupando formas semelhantes;

Observação em estereomicroscópio do Laboratório de Paleobotânica do IGc/USP, desenhando com câmara clara, fazendo morfometria e descrevendo as características de cada espécime; 
Documentação fotomacrográfica em câmara fotográfica Pentax K 1000 com lente de aproximação pertencente ao referido laboratório;

Elaboração de fichas de material bibliográfico semelhante para comparações;

Tratamento estatístico dos caracteres medidos (sempre que possivel) procurando definir espécies;

Descrição final de cada espécie, comparações com diagnoses originais e discussões sobre a sistemática;

Confecção das estampas.

Verificação das distribuições estratigráficas, geográficas e paleoecológicas.

\section{III.3.3. Para Microfitofósseis}

\section{Amostragem de superficie}

As amostras selecionadas para estudo foram as correspondentes a litologias mais acinzentadas escuras. São proveniente da Fazenda Santa Marta e, uma vez que as amostras da Fazenda Morro Alegre, embora também escuras, se mostraram contendo material mal preservado e de difícil identificação após tratamento palinológico.

\section{Processamento das amostras}

O material selecionado para estudos palinológicos foi processado conforme tratamento habitual em Palinologia do Paleozóico superior seguindo a preparação palinológica de Moore \& Webb (1978) e dos pesquisadores brasileiros (Quadros \& Mello, 1987; Dias, 1993 e Souza, 1996).

O tratamento físico-químico utilizado, denominado de maceração, cujo método varia em função da natureza química da rocha e objetiva a eliminação dos componentes minerais e orgânicos não-palinomorfos, constitui-se conforme as etapas seguintes:

\section{Trituração da rocha em almofariz;}

1- Peneiramento, homogeneização e pesagem de até 30 gramas por amostras; 
2- Maceração com ácido clorídrico, no caso das amostras carbonáticas, até a eliminação dos componentes minerais carbonáticos, sob teste visual;

3- Maceração com ácido fluorídrico durante 24 horas, para a eliminação dos componentes silicáticos;

4- Maceração com ácido clorídrico, a quente $\left(+65^{\circ} \mathrm{C}\right)$, para a eliminação dos fluorsilicatos/sílica-gel formados.

5- Cada processo de maceração foi seguido de lavagem de amostra com água destilada até a eliminação do componente ácido adicionado.

6- Após a maceração, o resíduo palinológico foi peneirado procurando-se concentrar o material. Esse foi, em seguida, conservado com água destilada em cápsulas de vidro devidamente codificadas.

\section{Confecção das lâminas}

O material processado não acusou bons resultados, então foram utilizadas as amostras para confecção das lâminas gentilmente cedidas pelo Dr. Roberto lanuzzi que realizou coleta em 1995 na área de estudo.

As lâminas foram montadas sobre chapa quente a partir da inclusão de gotas do resíduo em Entellan e recobertas por laminulas. Foram depositadas na laminoteca do IG/SMA sob os números IG-P-286A a C.

\section{Análise microscópica}

As lâminas confeccionadas foram analisadas nos Microscópios Ópticos Carl Zeiss adquiridos pelo Projeto Temático FAPESP 97/03639-8, estando um sob a guarda do Laboratório de Óptica do Departamento de Geologia Sedimentar do Instituto de Geociências da USP e outro, do Laboratório do Instituto de Geológico da Secretaria do Meio Ambiente do Estado de São Paulo (ambos com aumentos de $16 \times 10,40 \times 10,63 \times 10$ e 100×10), de modo a identificar os diferentes táxons presentes em cada lâmina. As melhores formas para fotomicrografias foram selecionadas e devidamente localizadas por meio de lâmina England Finder.

\section{Fotomicrografias}

Essas formas selecionadas para ilustrarem as estampas foram fotografadas no fotomicroscópio Óptico Carl Zeiss Modelo Axiophoto II do Laboratório de Óptica 
do Departamento de Geologia Sedimentar e Ambiental do Instituto de Geociências da USP, em filme colorido, nos aumentos de $40 \times 10$ e 63×10, com óleo de imersão e com optovar de 1,0 e 1,25, por ser esse dotado de contraste interferencial de fase (sistema DIC ou Normanski), que garante a superioridade da reprodução fotográfica dos aspectos tridimensionais dos grãos.

\section{Estudo sistemático}

Os táxons reconhecidos nas 3 lâminas provenientes da Fazenda Santa Marta foram estudados, sistematicamente, pela comparação com formas conhecidas no Brasil sobretudo, identificados por Souza (2000, inédito) para o Subgrupo Itararé no Estado de São Paulo, e com diagnoses originais do Paleozóico superior.

Visando um resultado mais imediato e pragmático optou-se pela listagem das formas apenas, com indicação de suas fotos e localização em lâminas. Posteriormente, com base em dados qualitativos e quantitativos procurou-se dar uma melhor idéia da composição paleoflorística e extrair informações sobre suas afinidades botânicas, paleoecológicas e posicionamento palinozonológico. 
CAPÍTULO IV 


\section{CAPÍTULO IV. PESQUISAS PALEOBOTÂNICAS PRÉVIAS DA TAFOFLORA ESTUDADA}

O estudo da tafoflora da Fazenda Santa Marta tem o seu histórico resumido no quadro da Fig.IV.1. Foi iniciado com o anúncio de sua descoberta por Millan et al. 1982, registrando as presenças dos gêneros: Paracalamites, Sphenophyllum, Cordaites e Cordaicarpus. Após uma nova coleta no afloramento Millan (1987b) identificou um novo constituinte da tafoflora: Botrychiopsis plantiana (Carr.) Archangelsky \& Arrondo 1971 e reconheceu a espécie Paracalamites australis Rigby 1969.

Nesse mesmo ano, Millan (1987a), ao propor um zoneamento fitoestratigráfico para o Subgrupo Itararé, no Estado de São Paulo, considerou essa tafoflora dentro do "Piso Florístico Medianense-Subpiso Itapevense", que caracterizou pela abundância de Botrychiopsis plantiana e presença de Paracalamites australis. Datouo como de idade estefaniana, com base em sua proximidade geográfica a Araçoiaba da Serra, onde Lima et al. (1976) haviam registrado a ocorrência de foraminíferos arenáceos, esporos zonados, grãos de pólen monossacados e raros bissacados estriados, uma assembléia que correlacionaram ao intervalo GH1 de Daemon \& Quadros (1970).

O Piso Florístico Medianense, que conteria ainda as tafofloras de Buri (Subpiso Buriense) e Cesário Lange (Subpiso Cesáriolangense), foi proposto por Millan (1987a) numa posição bioestratigráfica intermediária entre: a) o Piso Montemorense, caracterizado pela presença de licopsidas arborescentes (Lepidodendron, Lycopodiopsis e Brasilodendron) e esfenópsidas (Sphenophyllum e Paracalamites) associadas a formas gimnospermopsidas tais como: Nothorhacopteris, Botrychiopsis (B. weissiana e B. plantiana), Paranocladus, Adiantites, Ginkgophyllum e pela ausência de glossopterídeas- que correlacionou à passagem Tupense/Trampeaderense da bacia de Paganzo, na Argentina e b) o Piso Cerquilhense, caracterizado pela presença de protoglossopterídeas tais como: 
Rubidgea, fertiliger do tipo Brasilóide e de esfenópsidas (Phyllotheca, Paracalamites) e cordaitales do gênero Cordaites; com ausência de licópsidas arborescentes, bem como de Adiantites, Nothorhacopteris, Botrychiopsis, que considerou mais jovem que a tafoflora Montemorense e ainda, graças à ausência indubitável do gênero Glossopteris, de aparência mais antiga que as associações do Subgrupo Itararé no Estado do Rio Grande do Sul.

Em 1989, Millan registrou a presença de dois taxa Trizygia e Paracalamites ao estudar as esfenófitas da tafoflora Santa Marta. O primeiro descrito com duas espécies: Trizygia cf. T. sino-coreana e Trizygia cf. $T$. speciosa, representado por formas foliares dissociadas dos verticilos originais, foi assinalado então, pela primeira vez no Eogondwana brasileiro. O segundo, identificado como Paracalamites australis, representava moldes medulares de caules articulados sem ramos, desfolhados e estéreis de distribuição cosmopolita. Concluiu que associados, com Botrychiopsis plantiana, coniferófitas, sementes platispérmicas e prováveis rizomas e raízes constituiriam uma assembléia fitofossilífera alóctone.

Millan (1991a) assinalou espécies de sementes platispérmicas nessa tafoflora registrando a presença de Cordaicarpus zeilleri Maithy e Samaropsis sp.

No mesmo ano, Milian (1991b) estudou as esfenófitas, representadas por elementos das ordens Sphenophyllales e Equisetales descrevendo e figurando as espécies Sphenophyllum cf. S. churulianum Srivastava \& Rigby 1983; Sphenophyllum sp. e Paracalamites australis Rigby 1966a.

Millan, em 1993 identificou folhas de cordaitales como Cordaites cf. C. spathulata (Dana) Rigby, Maheshwari \& Schopf nessa mesma tafoflora. Também, nesse trabalho, discutiu a prioridade do nome Cordaites sobre Noeggerathiopsis.

Mais tarde, Millan (1995a) registrou a ocorrência de uma nova espécie de sementes platispérmicas preservada como impressões: Samaropsis itapevensis sp. nov.

Nesse mesmo ano, Millan (1995b) notificou, pela primeira vez no Grupo Tubarão, a ocorrência de Nothorhacopteris argentinica (Geinitz) Archangelsky \& Arrondo, proveniente da camada síltica fossilifera de cor castanho-escuro, da 
fazenda Santa Marta, em associação a B. plantiana. Ressaltou, assim, que a presença de Nothorhacopteris argentinica, nessa tafoflora, corrobora com a informação de Millan (1987a) de que a tafoflora de Itapeva (de mesma faciologia que a de Buri) seria mais antiga que as de Cerquilho e Cesário Lange e provavelmente mais jovem que a tafoflora de Monte Mor, SP.

\begin{tabular}{|c|c|c|c|c|c|c|c|}
\hline Yinlaro, & 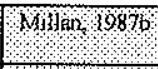 & Niilio 1880 & 101101091 & Milan, 19011 & Nision 199 & Milan 195 & Milar 1006 \\
\hline Porolanilos & & 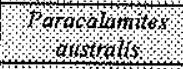 & & 1 oustralis & Yrrocolanivos & & poracolomions \\
\hline \multirow[t]{6}{*}{ 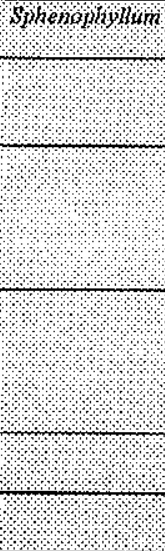 } & & & & Whonow & 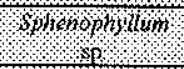 & & Spherophilhwor \\
\hline & & & & ohithronvim & 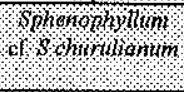 & & Solopophionow \\
\hline & & 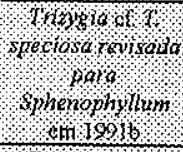 & & & & & \\
\hline & & 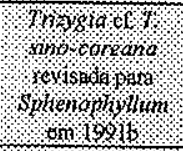 & & & & & \\
\hline & Bolon siopos & & & & Bornoniopsing & & 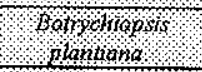 \\
\hline & & & & & & & 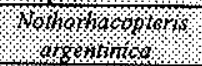 \\
\hline $60 \%$ Hor & & & & & Wolowis & & 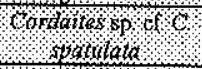 \\
\hline Cordiroon or & & & rordorowor & & 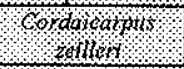 & Cordororph & vordorgorols \\
\hline & & & Somoropsis s & & & oromarossion & Sangrorolom \\
\hline
\end{tabular}

QuadroIV.1. Síntese do histórico do desenvolvimento das pesquisas paleobotânicas da Fazenda Santa Marta (SP). 
CAPÍTULO V 


\section{CAPÍTULO V. SISTEMÁTICA PALEOBOTÂNICA}

\section{V.1. Generalidades}

Como já é amplamente conhecida, a sistemática paleobotânica, diferentemente da sistemática botânica, está apoiada sobre material vegetal preservado de modo fragmentar, aplicando-se a nomenclatura binominal de Lineu para caules, folhas, raizes, sementes ou aparelhos reprodutivos encontrados quase sempre separadamente.

Se para o botânico representa um enorme desafio estabelecer um sistema natural de classificação das plantas atuais, para o paleobotânico, estabelecer ligações entre os diferentes órgãos fossilizados e desses fitofósseis com a sistemática vegetal, são tarefas quase impossíveis às quais se lança. Através de artifícios tais como atribuição a gêneros-forma ou morfogênero e gêneros-órgãos ou organogêneros, essa tarefa é, tentativamente, iniciada.

Os fitofósseis aqui estudados estão dispostos sistematicamente; utilizando-se do expediente acima exposto. Para as classificações de categoria taxonômicas superiores são seguidas aquelas sugeridas pelos estudiosos desses mesmos gêneros e pelo esquema de classificação proposto por Stewart \& Rothwell (1993:2627) que tentam, por meios cladísticos, inserir os fitofósseis nos grupos vegetais atualmente estabelecidos.

A lista de componentes da tafoflora Santa Marta, obtida após o estudo de revisão e complementação dessa tafoflora, é a seguinte:

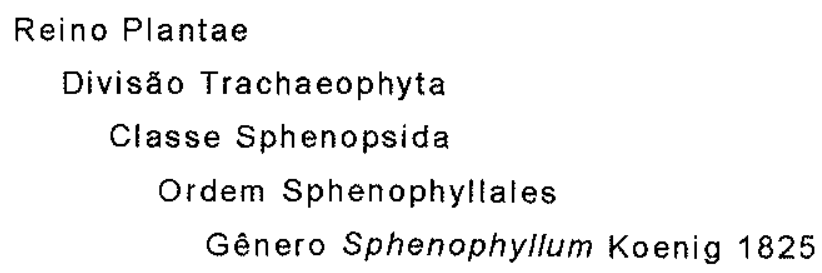

Sphenophyllum cf. S. churulianum Srivastava \& Rigby 1983

Sphenophyllum cf. S. rhodesii Rigby 1966a

Sphenophyllum sp. A

Ordem Equisetales sensu Boureau 1964 
Gênero Koretrophyllites Radczenko 1955

cf. Koretrophyllites sp.

Gênero Paracalamites Zalessky 1927

Paracalamites australis Rigby 1969 nov. emend.

Paracalamites levis Rigby 1966a nov. emend.

Paracalamites montemorensis Millan 1977 nov. emend.

Paracalamites sp.

Classe Gymnospermopsida

Ordem Pteridospermales Oliver \& Scott 1904(?)

Gênero Botrychiopsis Kurtz 1895a emend. Archangelsky \& Arrondo 1971.

Botrychiopsis plantiana (Carruthers) emend. Archangelsky \& Arrondo 1971

Gênero Eusphenopteris Novik 1947

cf. Eusphenopteris sp. Novik 1947

Gênero Nothorhacopteris Archangelsky 1983

Nothorhacopteris cf. N. argentinica (Geinitz) Archangelsky 1983

Aflébia de Nothorhacopteris cf. N. argentinica (Geinitz) Archangelsky 1983

Ordem Cordaitales Grand'Eury (1877)

Gênero Noeggerathiopsis Feistmantel 1879 emend. McLoughlin \& Drinnan 1996 Noeggerathiopsis sp.

SEMINAE INCERTAE SEDIS

Gênero Cordaicarpus Geinitz 1862

Cordaicarpus zeilleri Maithy 1965

Gênero Samaropsis Goeppert 1864

Samaropsis itapevensis Millan 1995a

Comparando essa listagem àquela que reúne todos os elementos descritos por Millan (1982 a 1995) chega-se ao quadro V.1. abaixo, que permite uma idéia dos avanços adquiridos no conhecimento da tafoflora Santa Marta, até o momento. 


\begin{tabular}{|c|c|c|}
\hline & Milian $(082,1055)$ & Nessa Dissertacao \\
\hline Esfenopsidas & 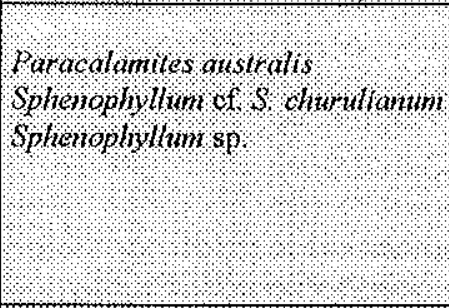 & 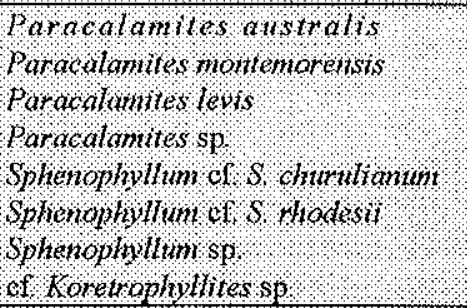 \\
\hline Proginnospermopsidas & 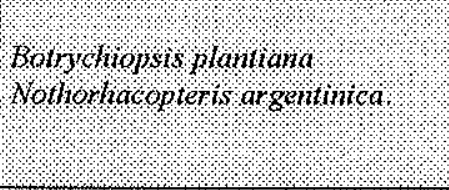 & 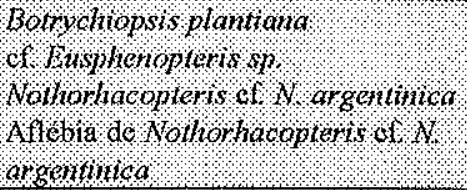 \\
\hline Gimnospomopsidas & 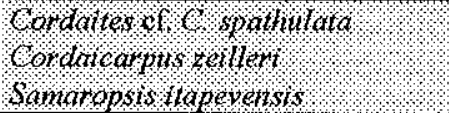 & 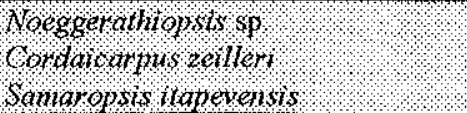 \\
\hline
\end{tabular}

Quadro V.1. Lista dos componentes da tafoflora Santa Marta conhecido até 1995 e daqueles registrados após a revisão nessa dissertação. 


\section{V.2. Reino Plantae}

Divisão Tracheophyta

Classe Sphenopsida

Os representantes desta classe caracterizam-se, basicamente, por apresentarem caules articulados, folhas dispostas verticiladamente nos nós e os ramos, quando presentes, também saindo lateralmente de nós e alternos com as folhas. Apresentam ainda canais protoxilemáticos em seus caules. Formam densos estróbilos terminais ou dispostos em verticilos.

Essa classe está presente na história vegetal do planeta desde o Devoniano e alcançou sua abundância e diversidade máxima no fim da Era Paleozóica (Raven et al. 1996).

O único gênero vivo é isosporado, contudo, alguns heterosporados apareceram ao longo do tempo geológico.

Trata-se da segunda classe mais abundante na tafoflora Santa Marta.

Das quatro ordens dessa classe (Hyeniales, Pseudoborniales, Sphenophyllales e Equisetales) apenas duas são aí registradas: Sphenophyllales e Equisetales. A primeira está aqui representada pelo gênero Sphenophyllum Koenig 1828. A segunda, pelos gêneros Koretrophyllites Radczenko 1955 e Paracalamites Zalessky 1927.

\section{Ordem Sphenophyllales}

Como apresentado por Stwart \& Rothwell (1993) a ordem das esfenofilales correspondia a plantas devonianas a neopermianas, provavelmente sarmentosas (rastejantes ou trepadeiras), herbáceas, que constituiam, principalmente, a vegetação do substrato de pântanos carboníferos. Eram providos de longos eixos delicados, de estrutura interna trímera, com verticilos portando seis, nove ou dezoito folhas, geralmente cuneiformes, de cuja base constricta partiam uma ou duas veias que se dicotomizavam duas a seis vezes antes de alcançarem as margens foliares. 
Devido a ausência de órgãos reprodutivos, considera-se aqui diretamente o gênero sem referências à sua família.

\section{Gênero Sphenophyllum Koenig 1825}

Segundo Boureau (1964) e Maheshwari (1968) o gênero Sphenophyllum foi proposto por Koenig (1825) para certas plantas que Brongniart (1822) havia descrito sob a designação genérica Sphenophyllites. Somente mais tarde uma definição detalhada ("diagnose") foi dada por Seward (1898).

O gênero Sphenophyllum apresenta um caule delgado e maciço, com poucas cristas longitudinais, não alternantes nos sucessivos entrenós, verticilos foliares com folhas em número sempre múltiplo de três. Suas folhas têm aspecto variável segundo as espécies. Eles podem variar desde uma forma cuneiforme até oval e seus bordos laterais podem ser côncavos, retilíneos ou convexos. A margem externa (apical) apresenta-se reta ou curva, indivisa ou provida de dentes agudos ou obtusos, lacinada ou franjada, às vezes, profundamente lobada ou filamentosa.

Geralmente suas folhas são isomórficas e radialmente simétricas em relação ao eixo caulinar. Contudo, há certos Sphenophyllum que sofrem um polimorfismo foliar acentuado sobre um mesmo caule, apresentando, em certos verticilos, folhas simples e, em outros, folhas divididas.

Há casos ainda em que se verifica uma variação morfológica foliar no próprio verticilo, com folhas de diferentes tamanhos e contornos. Para essas formas cujos verticilos apresentam pares foliares múltiplos de três, polimórficos, dispostos em simetria bilateral em relação ao eixo caulinar, Royle (1839, apud Boureau 1964) criou o gênero Trizygia.

Com base no aspecto venação curvilínea de cada folha, Asama (1970) erigiu os gêneros Parasphenophyllum e Paratrizygia, em contraposição à venação foliar retilínea de Sphenophyllum e Trizygia, respectivamente.

Autores como Maheshwari (1968) e Boureau (1971) apoiaram essas divisões em taxa distintas. 
Cabe ressaltar que Maheshwari (op cit.) demonstrou a existência de diferenças que justificam a separação dos dois gêneros. Essas diferenças seriam, além das de ordem paleogeográfica, principalmente quanto às características da epiderme. Assim, pelo menos Trizygia speciosa Royle, não poderia ser considerada dentro do gênero Sphenophyllum.

Contudo, outros como Srivastava \& Rigby (1983) contestaram a aplicabilidade dessas designações no caso de espécimes fragmentados ou folhas isoladas onde não seria possivel verificar o isomorfismo ou polimorfismo de verticilos foliares, a simetria dos verticilos foliares ou até mesmo distinguir-se entre o final da margem lateral e o início da margem apical de uma folha. Consideraram, também, subjetiva a definição de margem apical para interpretar, por exemplo, curvatura lateral das veias. Assim, para eles, os gêneros Parasphenophyllum e Paratrizygia estão desprovidos de uma base mais consistente e não podem ser mantidos.

Como aqui se está tratando com fragmentos de verticilos ou com folhas isoladas, não é possível a constatação do iso-ou polimorfismo entre verticilos ou mesmo em um só verticilo. Apenas a venação curvilínea ou retilínea de cada folha pode ser verificada. Entretanto, devido a falta de maior consistência para determinar a separação genérica entre Sphenophyllum e Parasphenophyllum conforme Srivastava \& Rigby (1983), parece ser mais apropriado o uso da designação genérica cf. Sphenophyllum apenas. Uma característica a ressaltar é o caráter tamanho extremamente diminuto de alguns espécimes da tafoflora Santa Marta.

Um fato digno de nota é que as ocorrências de Sphenophyllum tanto em Monte Mor como em Itapeva, (em níveis do Subgrupo ltararé cronoestratigraficamente atribuidos ao Westfaliano final- Estefaniano inicial) podem ser consideradas as mais inferiores para o Gondwana, já que a ordem ocorre, na própria bacia do Paraná (Formação Rio Bonito, Rösler 1974, e Formação Rio do Rasto, Rösler \& Rohn 1985); na Argentina e demais países gondvânicos, apenas no Permiano segundo Cúneo et al. (1993) e McLoughlin (1992). 


\section{Sphenophyllum cf. S. churulianum Srivastava \& Rigby 1983}

\section{Est.1, Fig.7}

\section{Sinonímia:}

1991b-Sphenophyllum cf. S. churulianum Srivastava \& Rigby 1983. Millan (1991b, Est.l, Fig.2).

\section{Espécime identificado: MN/MNUFRJ: 1962Pb}

\section{Descrição:}

O espécime 1962Pb MN/UFRJ (Est.1, Fig.7) corresponde a uma impressão foliar isolada incompleta, com ápice e base fragmentados. Mede $35 \mathrm{~mm}$ de comprimento por $25 \mathrm{~mm}$ de largura máxima (próxima ao seu ápice) e uma proporção de 1,4:1. A venação é dicotômica, sem anastomoses, retilínea a sub-retilínea na região central. As veias arqueiam-se suavemente até as margens laterais. Cada veia, ao longo de sua trajetória, sofre de duas a três dicotomias sucessivas e o seu número é variável em cada região do limbo foliar. Duas a três veias estão presentes na região próxima a base, uma vez que está fragmentada. Cerca de dez veias cobrem a região mediana, e na região apical não se pode observar quantas, já que está fragmentada. Observa-se uma equivalência do calibre venular $(1 \mathrm{~mm})$, após cada dicotomia.

\section{Comparação}

O espécime 1962Pb MN/UFRJ assemelha-se a S. churulianum de Srivastava \& Rigby 1983 em: a) tamanho, embora a proporção comprimento x largura não possa ser verificada dado o caráter fragmentário do espécime, sugerindo contudo ter sido semelhante e b) comportamento das veias retilíneas, na porção central, e arqueadas lateralmente. Por essas características pela impossibilidade de conferir todas as características diagnósticas dadas a preservação fragmentária, prefere-se designá-lo Sphenophyllum cf. $S$. churulianum, concordando com Millan (1991b, Est. I, Fig.2). O espécime MN/UFRJ-1962Pb, por suas veias arqueadas tipo francamente 
flabeliforme, falta de margens laterais e apical distingui-se de Sphenophyllum sp. A de Millan (1981a, Est.V, Fig. 1-7 e Est. III, Fig.1).

\section{Distribuição Estratigráfica e Geográfica}

Deve-se ainda ressaltar, que esta espécie tem sua ocorrência em Churulia, East Raniganj Coalfield, West Bengal (segundo Srivastava \& Rigby, 1983) na Índia, no andar Barakar do Permiano inferior (Artinskiano) portanto, em nivel cronoestratigráfico mais alto do que a ocorrência ora registrada.

\section{Sphenophyllum cf. Sphenophyllum rhodesii Rigby 1966a \\ Est.1, figs.3-6}

\section{Sinonimia:}

1991b-Sphenophyllum sp. Millan (1991b, Est.I, figs.3 e 4)

Espécimes identificados: GP/3E 8912A e A', 8912D e D' e MN/UFRJ: $1963 \mathrm{PbA}$ e $\mathrm{B}$.

\section{Descrição:}

Os espécimes GP/3E 8912A e A' (Est.1, Fig.4) são duas impressões foliares em disposição verticilada. O espécime 8912A está muito fragmentado e de difícil descrição e o 8912A' apresenta-se de forma obcuneada, com 10,5mm de comprimento por $8 \mathrm{~mm}$ de largura máxima a um terço do ápice. Esse último possui margens apicais e laterais lisas, ápice arredondado/truncado, base fragmentada aparentemente, contraída/cuneada. A venação é repetidamente dicotomizante, sem anastomoses, retilínea na parte central a sub-retilíneas nas laterais. Cada veia, ao longo de sua trajetória, sofre de duas a quatro dicotomias sucessivas e o seu número é variável em cada região do limbo foliar. Veia basal não visivel. Na região mediana, há cerca de quatorze veias e vinte e duas, na região apical. Observa-se uma equivalência do calibre venular $(1 \mathrm{~mm})$, após cada dicotomia, exceto na porção apical onde é um pouco reduzido $(0,7 \mathrm{~mm})$. 
Os espécimes GP/3E 8912D e D' (Est.1, Fig.3) são duas impressões foliares de forma obcuneada, ligadas em verticilo, medindo $7 \mathrm{~mm}$ de comprimento por $5 \mathrm{e}$ $4 \mathrm{~mm}$ de largura máxima, respectivamente. Possuem margem distal inteira arredondada e base aparentemente contraída/cuneiforme. A venação é, repetidamente, dicotomizante, sem anastomoses. Algumas veias parecem intersectar a margem lateral das folhas, enquanto a maioria intersecta a margem apical. São retilíneas a sub-retilíneas na parte central.

Cada veia, ao longo de sua trajetória, sofre de duas a quatro dicotomias sucessivas e o seu número é variável em cada região do limbo foliar. Veia basal não é visível, 8-14 veias presentes na região mediana e, na região apical, 8-23. É possivel observar uma equivalência do calibre venular $(1 \mathrm{~mm})$, mesmo após cada dicotomia.

Os espécimes 1963PbA e $\mathrm{B}$ foram descritos e documentados fotograficamente por Millan (1991b, Est. I, figs. 3 e 4).

\section{Comparação}

Os espécimes MN/UFRJ- 1963 PbA e 1963PbB (Est.1, figs.5 e 6) é comparável a Sphenophyllum sp. A de Millan (1981a, Est.l, Fig.3) no aspecto de venação ligeiramente aberta para as margens embora retilínea no centro, e pela aparente sinuosidade de margem apical, contudo distingue-se pelo tamanho muito menor e ausência de reentrância na região apical.

Ao comparar os espécimes GP/3E 8912A e A', 8912D e D' e 1963PbA e B com $S$. modesii Rigby (1966a) verifica-se as seguintes características em comum: folhas de tamanho muito pequeno, obcuneadas, quase tão longas quanto largas $(1: 1,3 / 1: 1,4)$, de margem distal inteira, com venação sucessivamente dicotomizante, veia basal não visível, algumas veias intersectando a aparente margem lateral das folhas, enquanto a maioria intersecta a margem apical. Por tais características, esses espécimes, são considerados muito próximos a Sphenophyllum rhodesii, preferindo-se designá-los, entretanto, Sphenophyllum cf. S. rhodesii Rigby 1966a por estarem muito incompleto. 


\section{Discussão}

Millan (1991b) ao comparar o espécime 1963PbA e B (impressão e contra impressão) com Sphenophyllum speciosum (Royle) McClelland por Archangelsky (1958, Lám VII, Fig.2-3) e sinonimizada em Trizygia speciosa Royle por Asama (1970, Pl.1, Fig.2) constatou similaridades com esta espécie com base em sua morfologia foliar, margens laterais e apical e venação. Entretanto, outros detalhes não foram observados como simetria e iso ou anisofilia por se tratarem de formas dissociadas dos verticilos foliares originais, preferindo, então, designar o espécime como Sphenophyllum sp. Agora é aqui sinonimizado como Sphenophyllum cf. S. rhodesii Rigby 1966a, juntamente com os espécimes GP/3E 8912A e A' e GP/3E $8912 \mathrm{D}$ e D'.

\section{Distribuição Geográfica e Estratigráfica}

A espécie S. rhodesii tem sido registrada na bacia de Perth, Austrália, nas camadas hulheiferas Irven Rives (segundo McLoughlin \& Drinnan, 1996 e Skwarko, 1993). 


\section{cf. Sphenophyllum sp.}

\section{Est.1, figs.1 e 2}

\section{Sinonímia:}

1991b- Sphenophyllum cf. S. churulianum Srivastava \& Rigby (1983) Millan, p.234, Est.l, Fig.1.

Espécime identificado: MN/UFRJ: 1961Pb A e B.

\section{Descrição:}

O espécime 1961PbA e B MN/UFRJ (Est.1, figs.1 e 2) correspondem também, a uma impressão foliar destacada. O espécime 1961PbA tem contorno cuneiforme, ápice arredondado/truncado, base fragmentada e margens laterais retas, ligeiramente convergentes na porção proximal. Tem $19 \mathrm{~mm}$ de comprimento e a largura máxima, próxima ao ápice, mede $14 \mathrm{~mm}$. A venação subparalelinérvea tem comportamento retilíneo a subretilíneo. Apresenta duas a três dicotomias sucessivas até a margem. Observam-se cerca de seis veias ou menos na base fragmentada, dezesseis, na porção mediana e 25 , na região apical. O calibre das veias é, aproximadamente, constante por toda a lâmina foliar.

\section{Comparação}

Revisando o espécime 1961PbA, considerado por Millan (1991b) como Sphenophyllum cf. $S$. churulianum, verifica-se que ele distingue-se de $S$. churulianum Srivastava \& Rigby (1983) por alguns caracteres diagnósticos importantes: 1) a proporção comprimento x largura não é de 3:1 mas apenas de $1,3: 1$; a forma foliar não é lanceolada, subtriangular ou obovada mas francamente cuneiforme; 3) o ápice não é obtuso mas francamente truncado; 4) não apresenta vênulas arqueadas para as margens laterais mas curso reto em direção à margem apical.

Características como forma cuneada e vênulas retilíneas atingindo apenas a margem apical, aproximam esse espécime de espécies neocarboniferas euroamericanas como $S$. emarginatum (Brongniart) Koenig, $S$. cuneifolium e $S$. 
costae observadas em Boureau (1964, figs. 22, 23, 31, 32) mais que de espécies permianas gondvânicas. Entretanto delas também se distingue por não apresentar margens apicais crenuladas. Assim sendo, configura-se melhor considerá-la como Sphenophyllum sp.

\section{Considerações Gerais sobre o Gênero Sphenophyllum na tafoflora}

Comparando os exemplares estudados com aqueles de Sphenophyllum paranaensis de Dorizon, Formação Rio do Rasto, Estado do Paraná, de Rösler \& Rohn (1985, Est.1, figs. 1-4, 7-9; Est. 2. figs. 1-5, Est. 3, figs. 1-3) nenhuma característica em comum foi possível verificar exceto as nervuras laterais sempre curvas dessa espécie, observadas também no espécime 1962Pb.

A espécie Sphenophyllum brasiliensis Rösler (1974, Fig.1) apresenta suas folhas com bordos laterais ligeiramente convexos, com sua maior largura localizada entre a porção mediana e distal; bordo externo com dentes e incisões com profundidade de $1 \mathrm{~mm}$ e venação com 3 ou mais dicotomias sucessivas em intervalos de $2 \mathrm{~mm}$. Estas características não são encontradas no material de Itapeva, SP.

Os exemplares de Sphenophyllum sp. A de Monte Mor, SP (Millan, 1972, Est.V, figs. 5-9; Est. II, figs. 1-2; Est. XI., Fig.1; 1981, Est.I, figs.1-7; Est. II, Fig.1) possuem folhas verticiladas e destacadas cuneiformes, com margens laterais ligeiramente côncavo-convexas, margem apical suavemente fendida e sinuosa e venação flabeliforme. Excetuando-se a forma semelhnte verificada nos espécimes $1961 \mathrm{~Pb}$ e $1963 \mathrm{~Pb}$, as outras características não são encontradas no material de Itapeva.

Portanto, as Sphenophyllales da tafoflora Santa Marta constituem-se formas especificamente distintas das demais encontradas na bacia do Paraná, incluíndo-se aí a de Monte Mor ainda que de possível mesmo nível estratigráfico. 


\section{Ordem Equisetales}

Como foi mencionado por Taylor (1981), inicialmente, as equisetales eram representadas por um pequeno número de taxa, relacionados entre si na base de seu hábito herbáceo e falta de tecido secundário. A ordem Calamitales, por sua vez, foi estabelecida para agrupar aqueles gêneros que eram arborescentes e produziam tecidos secundários.

Posteriormente, estudos abrangendo vários gêneros de esfenófitas sugeriu que o hábito herbáceo ou arborescente, morfologia dos esporos, cones providos ou desprovidos de brácteas e o grau de fusão das folhas não podem ser usados como definitivos para separar esses dois grupos. Assim, atualmente, se considera todo $O$ gênero relacionado às duas ordens dentro de uma única: Ordem Equisetales. A fusão das duas ordens numa só é baseada na ausência de diferenças anatômicas e morfológicas entre os dois grupos, incluindo-se o reconhecimento de elatéres nos esporos de ambos, a similaridade de estrutura vascular primária e a organização meristemática dos eixos vegetativos. Assim sendo, Equisetum poderia ter evoluído de gêneros calamitáceos.

No geral, as Equisetales podem ser caracterizados como plantas articuladas, com cristas internodais longitudinais em seus caules. Ramos e folhas são nascidos em verticilos distintos. As folhas são uninérveas, soldadas ou livres. A porção subterrânea da planta é um rizoma portando numerosas raízes adventíceas. Os meristemas vegetativos contêm uma só célula apical grande e meristemas intercalares na base de cada entrenó. $O$ tecido vascular era organizado em feixes que se alternavam nos entrenós sucessivos. No entrenó, cada feixe possuía um canal protoxilemático. Esporângios eram recurvados e agrupados em estróbilos com brácteas estéreis ou ausentes. Esporos possuíam elatérios presos superficialmente. A história geológica das Equisetales pode ser traçada desde o Devoniano até 0 Recente, aparecendo entre os mais notáveis componentes da flora do Carbonífero.

$\mathrm{Na}$ tafoflora de Santa Marta, estão presentes dois gêneros da Ordem Equisetales: Koretrophyllites e Paracalamites. 


\section{Gênero Koretrophyllites Radczenko 1955}

Conforme Boureau (1964-Traité de Paléobotanique, III: 372-385), as formas consideradas dentro do gênero Koretrophyllites Radczenko 1955 foram, anteriormente, colocadas no gênero Phyllotheca Brongniart, sendo daí isoladas por suas características de folhas livres e pelas frutificações. Na Província de Angara, esse gênero tem ampla distribuição estratigráfica, sendo registrado desde o Carbonifero inferior (bacia de Kuznetsk) até o topo do Permiano (bacia de Tunguska). Ainda segundo Boureau (1964:372-385), esse gênero, por seu tipo de aparelho reprodutor, seria descendente dos Archaeocalamites do Devoniano superior-Carbonifero inferior (de Angara, na Ásia setentrional) e, durante o Carbonífero superior, teria migrado para a Europa Ocidental e para o Gondwana onde originaria, posteriormente, o gênero Phyllotheca. Em 1971, Boureau propôs entre outras, uma série evolutiva de folhas de esfenófitas que se iniciaria com Archaeocalamites e passando por Koretrophyllites, terminaria em três possiveis ramos: de Phyllotheca, de Schizoneura e de Equisetum. No estágio Koretrophyllites, as folhas são uninérveas e livres desde a base, inseridas em nós de caules do tipo Calamites.

Embora Meyen (1967) afirmasse que o gênero não ocuparia uma posição muito importante na filogenia das esfenófitas, correspondendo a ramos laterais ou terminais de Phyllotheca e, em 1971, tenha afirmado novamente que o gênero deveria ser incluido em Phyllotheca, nesse último trabalho se contradiz ao firmar que apenas haveria necessidade de informações mais detalhadas sobre sua espécietipo ( $K$. mungaticus), considerando que os dados conhecidos sobre o gênero não conduzem a sua invalidação.

Sua presença na tafoflora da Fazenda Goulart (S. Jerônimo, RS-Subgrupo Itararé), registrada por Andreis et al. (1979), Cazzulo-Klepzig et al. (1980) e GuerraSommer \& Cazzulo-Klepzig (1981) e agora em Itapeva, evidenciaria sua ocorrência desde o Carbonífero superior até o Permiano inferior (Sakmariano), no Gondwana brasileiro. 


\section{cf. Koretrophyllites sp.}

\section{Est.2, Fig.1}

\section{Descrição}

Dos três espécimes, duvidosamente, atribuídos a Koretrophyllites, apenas o espécime GP/3T 2260 apresenta-se um pouco menos fragmentado. Trata-se de uma impressão de fragmento caulinar articulado, apresentando 2 ou 3 verticilos foliares, num comprimento total de $13 \mathrm{~mm}$ e $1,3 \mathrm{~mm}$ de largura máxima, estreitando-se para o ápice. Exibe costelas e sulcos longitudinais pouco nítidos porque suas folhas se prolongam, decorrentemente, sobre o caule, confundindo-se com a parte superficial desse, de tal forma que suas linhas nodais se tornam imprecisas. Uma estrangulação ou afunilamento na parte inferior do entrenó é ressaltado pelos estreitamentos das costelas longitudinais nessa região.

As folhas verticiladas são simples, lineares estreitas, uninérveas, decorrentes, com finas estriações longitudinais, de provável ápice agudo, contudo, livres até a base (sem bainha) apecioladas, presas ao caule por toda a base. Embora livres, saem como feixes da base. O comprimento está entre $15 \mathrm{~mm}-40 \mathrm{~mm}$ e a largura até $1 \mathrm{~mm}$. São mais longas que os entrenós. Divergem em ângulo agudo e têm curso mais ou menos reto. Não é possivel determinar o número total de folhas por verticilo, contudo, de cada lado do entrenó observam-se 3 a 4 fragmentos foliares preservados mas, possivelmente, seriam muito mais. Não apresentam parte reprodutiva.

\section{Comparação e Discussão:}

Feições morfológicas tais como: 1) afunilamento dos entrenós na sua porção inferior; 2) nítido aspecto decorrente das folhas na região dos nós; 3) costelas longitudinais mais apertadas na parte inferior do entrenó e 4) linha nodal não muito nítida; que Radczenko (1955) apresentou como características distintivas para Koretrophyllites, podem ser observadas, sobretudo no espécime GP/3T 2260, ainda que mal-preservado e fragmentado. 
Dentre as feições morfológicas apontadas por Boureau (1964) para o gênero, os espécimes, ora estudados, apresentam como coincidentes: o caule com costelas e sulcos pouco marcados, possivelmente não alternantes na região do nó; as folhas simples, estreitas, pontiagudas, uninervadas, livres na base, dirigidas para 0 alto, saindo em feixes $($ Koretro $=$ feixes, phyllites $=$ folha) e geralmente mais longas que $o$ entrenó; nervura mediana fina; as folhas emergentes do caule recobrem parcialmente o entrenó, confundindo-se com sua parte superficial, de modo que a linha nodal é sempre imprecisa.

Essa forma foi observada pela primeira vez no Brasil por Andreis et al. (1980), entre os elementos componentes da assembléia tafoflorística da Fazenda Goulart, Município de São Jerônimo (RS) ocorrentes em afloramento do Grupo Itararé (sic), estando aí associada a Botrychiopsis (Kurtz) Archangelsky \& Arrondo, Chiropteris Kurr, Rubidgea Tate, Cordaites Unger e Cordaicarpus Geinitz. Os espécimes em estudo concordam em feições morfológicas e morfometria com os espécimes descritos para a Fazenda Goulart, identificados e figurados por Andreis et al. (1979, est. I, figs. 1, 3 e 4). Esses são novamente citados por Cazzulo-Klepzig et al. (1980) e Guerra-Sommer \& Cazzulo-Klepzig (1981) para o mesmo afloramento.

Contudo, sua identificação dúbia como cf. Koretrophyllites $\mathrm{sp}$. mostra-se mais verossímil para a localidade de Itapeva (SP), dado ao seu péssimo grau de preservação e à ausência de frutificações que permitam atribuí-los à Família Sorocaulaceae. 


\section{Gênero Paracalamites Zalessky 1927}

O morfogênero Paracalamites Zalessky abriga grande variedade de caules descritos na literatura paleobotânica do Neopaleozóico, conforme Rigby (1966a e b). Esses caules, com distribuição geográfica entre Angara e Gondwana, são encontrados nas ocorrências gondvânicas em conexão orgânica com Phyllotheca, Schizoneura, Raniganjia, Sphenophyllum, Stellotheca, Umbellaphyllites ou associados a diversos outros tipos de verticilos foliares de esfenópsidas. Apresentam sempre as mesmas características principais: caules e rizomas articulados, entrenós mais longos ou menos longos que largos, tendo nos contramoldes medulares, feixes vasculares e áreas interfasciculares opostos, ou seja, normalmente não-alternos na passagem da linha dos nós, dicotomizando-se e, em alguns casos, recombinando-se (ver Rigby 1969, Fig. 1).

Os espécimes caulinares articulados desprovidos de folhas, provenientes da tafoflora Santa Marta, não podem ser atribuídos com segurança a um único gênero provido de verticilo foliar de esfenópsida, dado serem igualmente encontrados associados a Koretrophyllites e a Sphenophyllum.

No Subgrupo Itararé, são registradas ocorrências de três espécies do gênero Paracalamites Zalessky: $P$. australis, $P$. levis e $P$. montemorensis. Freqüentemente, ocorre uma dúvida na identificação de alguns espécimes em uma ou em outra espécie. Para contornar esse problema, tentou-se estabelecer critérios mais acurados na distinção das três espécies levando em consideração as diagnoses originais (P. australis Rigby, 1966a: 123, Est. 32, fig 19 e Est. 33, figs 20 e 23 e $P$. australis Rigby emend. Rigby, 1969: $F_{2^{-}} F_{7}$, Est. 1, figs. $1-9$; Est. 2, figs. 6-8; est. 3 , figs. 4-8 e Fig. texto 1 e 2; P. montemorensis Millan, 1977: 201-202, Est. I, figs. 1015 e P. levis Rigby 1966a: 125 - 126, Est. 33, figs. 21 - 22) e as medidas dos respectivos espécimes. Dentre esses critérios os que se mostraram mais funcionais e válidos foram os referentes à relação morfométrica entre largura e comprimento dos entrenós. É assim, proposto aqui, se observar um intervalo mais ou menos fechado de variação na relação morfométrica largura / comprimento do entrenó, relação essa diagnóstica para cada espécie. 
Essa relação morfológica (largura/comprimento do entrenó), pelo que se observa, permanece constante seja ela obtida na região apical, na região mediana ou na região basal.

\begin{tabular}{|c|c|}
\hline Especies & 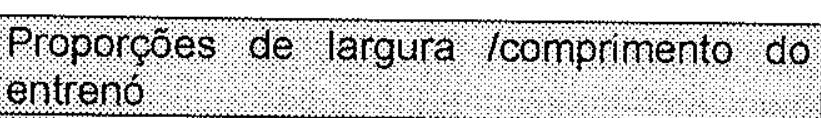 \\
\hline Paracalamites australis & 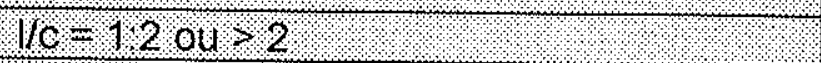 \\
\hline Paracalamites. montemorensis: & $11 c=1.1 .1 / 1.99$ \\
\hline Paracalamites levis & $1 / 0=1,0,9904<0,99$ \\
\hline
\end{tabular}

V.2. Quadro de morfometria das espécies de Paracalamites

Determinando-se as proporções, nota-se que, em $P$. australis, o entrenó é substancialmente mais longo que a largura do caule; $P$. montemorensis possui entrenós iguais a até quase duas vezes o largura do caule $e$, em $P$. levis, os entrenós são de comprimento mais curto que a largura do caule.

Adotando-se então esse critério registra-se na tafoflora da tafoflora Santa Marta, a presença das três espécies do Gênero Paracalamites, conforme segue sua descrição abaixo.

\section{Paracalamites australis Rigby 1966a emend. Rigby 1969 nov. emend.} Est.2, Fig.3 e Est.3, Fig.5

P. australis Rigby 1966a. Palaeontographica B118:123-124, PI. 32, Fig. 19.

Procedência: Grupo Collie, Bacia de Collie e Irwin Coal Measures, Bacia de Perth Austrália Ocidental.

\section{Sinonímia:}

ver Rigby (1969: $F_{2}-F_{3}$ ) completando com Bernardes-de-Oliveira (1977: 79-80) e 1972 - P. australis Rigby. Millan, p.50-56, Est. VI, figs. 4, 5 e 6 e Est. VII, Fig. 2, non Est. VI, figs. 3, 7 e 8 .

1972 - P. montemorensis. Millan. Millan, p. 58-61, Est VII, figs. 6 e 9 non Est. VII, figs, $4,5,7$ e 8 . 
1975 - P. australis Rigby. Millan, p. 3.

1977 - P. australis Rigby. Millan, p. 196 - 200, Est. I figs. 2, 5, 7 e 8, non Est. I, figs. $1,3,4$ e 6 .

1977 - P. montemorensis Millan. Millan, p. 201 - 202, Est. I, figs. 12 e 15 non Est I, figs, $10,11,13$ e 14 .

1991b - P. australis Rigby. Millan, p. 239-243, Est.Il, figs. 1, 2 e 3, non Est.I, figs. 5 e 6 e Est. II, figs. 4 e 5 .

Emended Diagnosis from Rigby 1969 whitch emended: "Articulate stem having ribs of pith cast opposite at nodes; ribs alternate only to accomodate changes in number of ribs between adjacent internodes. Rib vascular bundles continuous from one internode to the next without break; also vascular bundles dichotomize and recombine with vascular bundles branch of adjacent ribs at nodes. Ribs and furrows sometimes finely striated. Ribbing on node of external cast weak. Internodes substantially longer than stem diameter (1:2 or $>2)$, except in thick truncks".

Espécimes identificados: MN/1970Pb, 1977Pb e 1979Pb, depositados na Coleção Científica do Museu Nacional/UFRJ, procedentes da Fazenda Santa Marta, bairro Guarizinho, Itapeva (SP).

\section{Descrição:}

São três impressões de fragmentos de caule articulado, com nós e entrenós desprovidos de ramos, folhas e estruturas reprodutivas. Trata-se de moldes medulares apresentando sulcos ou caneluras correspondentes aos feixes vasculares proeminentes.

Os feixes vasculares e áreas interfasciculares paralelos, espaçados de $0,4 \mathrm{~mm}-0,5 \mathrm{~mm}$, são contínuos ou, raramente, alternos na passagem pela linha nodal e, freqüentemente, estriados longitudinalmente. As áreas interfasciculares são, geralmente, mais rasas que os feixes e com superfície apenas ondulada. 
O espécime $1970 \mathrm{~Pb}$ apresenta comprimento de $22 \mathrm{~mm}$ e largura de $3 \mathrm{~mm}$, exibindo apenas um nó fracamente marcado. Os entrenós apresentam comprimento de $10 \mathrm{~mm}$ enquanto a largura é de $3 \mathrm{~mm}(1: 3,33)$. O número de costelas sobre o lado visivel é 20 . O espécime $1079 \mathrm{~Pb}$ apresenta comprimento preservado de $25 \mathrm{~mm}$ e largura de $10 \mathrm{~mm}$, tendo nós fracamente marcados, às vezes quase imperceptíveis. O comprimento de cada entrenó é maior que $18 \mathrm{~mm}$ e sua largura de $9 \mathrm{~mm}(1: 2)$. 0 espécime $1977 \mathrm{~Pb}$ apresenta uma proporção de $1: 2,3$ entre a largura e 0 comprimento do entrenó.

\section{Comparação:}

Millan (1991b) havia identificado e descrito como Paracalamites australis os espécimes provenientes de Santa Marta e depositados no Museu Nacional sob os números 1970Pb, 1977Pb, 1979Pb, 1981PbA, $1981 \mathrm{PbB}, 1989 \mathrm{~Pb}, 1991 \mathrm{~Pb}$.

Examinando e fazendo a morfometria de todos os espécimes desta tafoflora Santas Marta atribuíveis ao gênero Paracalamites, depositados nas coleções científicas do Museu Nacional/UFRJ e do IGc/USP verificou-se que apenas três espécimes do Museu Nacional (1970Pb, 1977Pb e 1979Pb) figurados e descritos por Millan (1991b, Est.ll, figs.1 e 3) podem ser identificados como possuidores dos seguintes caracteres: caules articulados com costelas geralmente opostas nos nós, presença de estriações nas costelas e sulcos, feixes vasculares que se ramificam e se recombinam nas costelas adjacentes dos nós, apresentando entrenós substancialmente mais longos que o diâmetro do caule $(1: 2$ ou $>2)$, exceto nos caules mais espessos. Todos esses caracteres são considerados aqui diagnósticos de $P$. australis Rigby emend. Rigby 1969. nov. emend.

Segundo esses critérios, os demais espécimes foram remanejados para as duas outras espécies apresentadas a seguir. 


\section{Discussão:}

Embora a continuidade dos feixes vasculares na passagem da linha nodal seja a feição dominante, é possível observar uma alternância dos feixes, num ponto ou outro dessa linha. Em geral, esse fato está associado a um ligeiro aumento do número de feixes de um entrenó para o adjacente, conforme observado por Rigby (1969: $F_{3}$ ). Isso pode conferir à linha nodal um aspecto em zigue-zague, semelhante ao observado no subgênero Mesocalamites Himer 1927 do Namuriano Westfaliano A das floras Euroamericana e Angárica.

Contudo, dadas: a) a preservação precária dos espécimes estudados; b) a distinção imprecisa, muitas vezes, entre Paracalamites e Mesocalamites, conforme Boureau (1964: 244); c) a distribuição geográfica distinta; d) a ausência na assembléia fitofossilífera de aparelhos reprodutivos de tipos que ocorrem em Mesocalamites e e) a maior freqüência de feixes vasculares contínuos, prefere-se manter essas formas sob o morfogênero Paracalamites e sob a espécie $P$. australis.

Há que se observar, entretanto, que os espécimes de $P$. australis provenientes de Itapeva, são de dimensões, sensivelmente, menores que os espécimes australianos dessa espécie, contudo, as proporções são mantidas.

\section{Paracalamites levis Rigby $1966 \mathrm{a}$, nov. emend.} Est.2, figs.2 e 5 e Est.3, figs. 1 e 3

\section{Sinonimia}

1966a - Paracalamites levis Rigby. Rigby, p. 125-126, PI. 33, figs. 22 e 23.

1972 - P. cf. P. levis Rigby. Millan, p. 56, Est. VII, Fig. 3.

1972 - P. australis Rigby. Millan, p. 51, Est. VI Fig. 8.

1975 - P. cf. P. levis Rigby. Millan, p.3.

1977 - P. cf. P. levis Rigby. Millan, p. 200, Est. I, figs. 6 e 9.

1977 - P. australis Rigby. Millan, p. 198, Est. I, Fig. 6.

1991 b - P. australis Rigby. Millan, p. 239-243, Est. I, Fig. 5 e Est. II, Fig.4 (1981PbA - non, 1981PbB). 
Emended diagnosis of Rigby (1966a: 125-126): "Slender articulate stem (diameter minor or equal $10 \mathrm{~mm}$ ) having ribs of pith cast opposite at nodes; when number of ribs increasing at nodes, ribs may alternate. Nodes strongly or faintly defined, tubercles absent. Internodes shorter in length than stem diameter ( $\mathrm{d}: \mathrm{l}=1: 0.99$ or $1:<0.99$ ) pith narrowing gradually without bulbous swelling towards base, and without sharp decrease in length of internode. Foliage and fructification unknown".

Espécimes identificados: GP/3T - 2266 e GP/3T - 2267 (Col. IGc/USP), 1981PbA e 1989Pb ( Col. MN/UFRJ).

\section{Descrição:}

São quatro impressões de fragmentos caulinares articulados, com nós e entrenós desprovidos de ramos, folhas e estruturas reprodutivas. Apresentam comprimento da ordem de $24-65 \mathrm{~mm}$ e largura variando entre 8-62 mm. Observamse de 2-10 nós, forte ou fracamente marcados. Tubérculos estão ausentes. Os espécimes GP/3T - 2266 e 1989Pb, possíveis moldes caulinares externos apresentando costelas ou cristas (= feixes vasculares) paralelas, proeminentes, espaçadas de $0,4-0,5 \mathrm{~mm}$, contínuas ou alternadas na passagem da linha nodal. Os outros dois espécimes seriam moldes medulares, apresentando feixes vasculares paralelos, na forma de sulcos, com espaçamento similar, também contínuos, raramente alternos na região nodal. Os feixes vasculares e áreas interfasciculares são, freqüentemente, estriados longitudinalmente.

Os entrenós são mais largos que longos variando de $3,2-10,5 \mathrm{~mm}$ de comprimento por $5-12 \mathrm{~mm}$ de largura, numa proporção média de largura por comprimento de 1:0,57-1:0,91.

O número de costelas por feixes vasculares sobre o lado visível é estimado em 8 a 15. Geralmente, áreas interfasciculares rasas ou ligeiramente elevadas e largas $(0,4 \mathrm{~mm})$ estão associadas a feixes fundos, largos $(0,6 \mathrm{~mm})$ e estriados. 


\section{Comparação:}

Ao comparar os espécimes GP/3T - 2266 e 2267 da Coleção do IGc/USP, com os espécimes 1981PbA e 1989Pb da Coleção do Museu Nacional/UFRJ, coletados e identificados, como P. australis por Millan (1991b, Est. I, Fig. 5 e Est. II, Fig. 4) verifica-se que são, praticamente, idênticas em sua morfologia geral e inclusive quanto à proporção das medidas larguras por comprimento do entrenó (1: 0,99 ou $<0,99$ ). Essas características são consideradas diagnósticas para $P$. levis Rigby nov. emend. O espécime GP/3T - 2266 assemelha-se muito ao holótipo de $P$. levis figurado por Rigby (1966a, PI. 33, Fig. 21) proveniente de Collie Group, Austrália Oriental.

Também o número de costelas sobre a superfície visível dos espécimes brasileiros (cerca de 8) assemelha-se ao dos espécimes de Rigby (1966a), variando de 8 a 11.

\section{Discussão:}

Rigby (1966a e 1969), ao definir os caracteres diagnósticos de $P$. levis, afirmou que a largura ou diâmetro do entrenó é maior que o comprimento do entrenó.

Procurando definir melhor essa proporção em contraposição àquelas de $P$. montemorensis Millan E P. australis Rigby é que se considera aqui a referida proporção $(1: 0,99$ ou < 0,99) e adiciona-se esse caráter à diagnose. Os espécimes de Coleção MN/UFRJ, provenientes de Itapeva: 1989Pb (Millan 1991b, Est. I Fig. 9) e 1981PbA (Millan, 1991b, Est. II, Fig. 4A) identificados como P. australis são aqui colocados na sinonímia de $P$. levis por suas características diagnósticas.

\section{Paracalamites montemorensis Millan, 1977 nov. emend. Est.2, Fig.4 e Est.3, figs.2 e 6}

\section{Sinonímia:}

1941 - Phyllotheca sp. Read. Read, 12: 90, Est. 3, figs. 4 e 5. 
1972 - Paracalamites montemorensis Millan. Millan, p.58, Est. VII, figs. 4, 5, 7 e 8 non Est. VII, figs. 6 e 9.

1972 - P. australis Rigby. Millan, p. 50-56, Est. VI, figs. 4, 5 e 6 e Est. VII, Fig. 2.

1975 - P. montemorensis Millan. Millan, p. 3.

1977 - P. montemorensis Millan. Millan, p. 201, Est. I, figs. 10, 11, 13 e 14 non Est. I, figs. 12 e 15 .

1977 - P. australis Rigby. Millan, p. 196, Est. I, figs. 1, 3, 4 e 5 non Est. I, figs. 2,7 e 8.

1991b - Paracalamites australis Rigby. Millan, p. 239-243, Est. I, Fig. 6 , Est. II, figs. $4 B$ e 5 .

Emended Diagnosis: "Articulate stems, having striated, closed narrow ribs of pith cast, with dense aspect, opposed at nodes, having internodes longer than the stem diameter $(1: 1-1: 1,99)$. Foliage and fructification unknown.

Espécimes identificados: "1981PbB e 1991PbA (Col. MN/UFRJ) e GP/3T - 2264 (Col. IGc/USP)

\section{Descrição :}

São três impressões de fragmentos caulinares articulados, com nós e entrenós, desprovidos de ramos, folhas e estruturas reprodutivas. Possuem comprimento preservado de $20-35 \mathrm{~mm}$ e largura de $4-40 \mathrm{~mm}$. Normalmente, são observados de um a sete nós sobre os fragmentos caulinares preservados. A nitidez desses nós é variada, às vezes são quase imperceptíveis. Os entrenós apresentam largura variando de 3,5-13 $\mathrm{mm}$ e comprimento de 5 a $25 \mathrm{~mm}$, perfazendo uma proporção largura/ comprimento da ordem de 1:1 - 1: 1,99.

Os espécimes são moldes externos de caule, apresentando caneluras estreitas, muito juntas, estriadas, numerosas e opostas na passagem da linha nodal. Os tubérculos são ausentes. 
Os feixes vasculares e áreas interfasciculares não se alternam na região dos nós.

O número de costelas ou feixes vasculares sobre o lado visível é estimado de 6 a 16.

\section{Comparação:}

Os exemplares estudados apresentam uma estreita similaridade de características diagnósticas, incluindo-se as proporções largura/comprimento dos entrenós, com aquelas identificadas em $P$. montemorensis Millan e provenientes da tafoflora de Monte Mor (SP) figurados em Millan (1972, Est. VII, figs. 4, 5, 7 e 8 e 1977, Est. I, figs. 10, 11, 13 e 14).

\section{Discussão:}

Há que se ressaltar que alguns espécimes provenientes de Monte Mor (SP), atribuído por Millan a P. montemorensis devem ser sinominizandos em $P$. australis considerados os seus caracteres e medidas. Esses são: Millan (1972, Est. VII, Fig. 6 e 9 ) e ( 1977, Est. I, Fig. 12 e 15).

\section{Paracalamites sp.}

Est.3, Fig.4

Espécime identificado: GP/3T - 2265 (Col. 1Gc/USP)

\section{Descrição:}

Trata-se de molde externo de fragmento caulinar articulado, apresentando apenas um nó. É desprovido de ramos, folhas e estruturas reprodutivas. Apresenta comprimento superior a $13 \mathrm{~mm}$ e largura de $8,6 \mathrm{~mm}$. O nó é bem nítido e não há tubérculos. As costelas são contínuas na passagem da linha nodal, apresentando dicotomias e recombinações raras, correspondentes à redução de aumento do 
número de costelas e áreas interfasciculares no entrenó seguinte, chegando nesses pontos a sugerir alternância de costelas na passagem nodal.

\section{Discussão e Comparação:}

No espécime GP/3T- 2265 nenhum entrenó completo foi preservado. Assim, fica impossivel determinar com exatidão a proporção largura por comprimento do entrenó. Pelas medidas apresentadas sabe-se que essa proporção é 1:>1,5. Com essa proporção indefinida e na ausência de outros caracteres diagnósticos fica-se na dúvida se o espécime poderia ser identificado como $P$. montemorensis Millan emend. nov. ou como P. australis Rigby emend. nov. Nesses termos, prefere-se referi-lo como Paracalamites sp. 


\section{Classe Gymnospermopsida(?)}

Stewart (1981) reestabeleceu as Gymnospermopsida como uma classe de plantas vasculares compreendendo, no mínimo, duas linhas filéticas divergentes, cada uma das quais evoluiu certamente a partir de características distintas. Uma das linhas seria as das cicadófitas com suas folhas frondiformes grandes, caules com medula bem desenvolvida e córtex e xilema secundário manoxílico.

A segunda linha inclui as coniferófitas geralmente distintas por suas folhas uninérveas simples, caules lenhosos, compactos com lenho secundário picnoxílico.

Conforme Stewart \& Rothwell (1992) o reconhecimento de coniferófitas e cicadófitas permaneceu como um conceito útil para ajudar na identificação de fósseis de gimnospermas. Contudo, estudos recentes têm demonstrado, que essas categorias representam mais hábitos de crescimento de linhagens evolutivas e que há vários grupos distintos incluídos tendo em cicadófitas e coniferófitas.

Stewart \& Rothwell (1992) afirmam também que não há conhecimento até o presente se as gimnospermas são monofiléticas, bifiléticas ou polifiléticas, contudo, eles reconhecem a Classe Gymnospermopsida como definida pela ausência de características angiospérmicas mais que por um único caráter derivado ou conjunto de caracteres.

Assim, as gimnospermas não parecem ser uma linhagem natural, isto é, um grupo monofilético. Uma tentativa de estabelecer uma classe natural vem sendo feita no sentido de reconhecer um dado maior de plantas que se caracterizam por seus megasporângios indeiscentes (iie. plantas com preóculos e todas as plantas com sementes). Contudo, essa classe não foi ainda formulada. Por isso, aqueles autores consideram a Classe Gymnospermopsida até que uma classificação mais natural surja. 


\section{Ordem Pteridospermales Oliver \& Scott 1904(?)}

As Pteridospermales foram consideradas, por muito tempo, como englobando plantas frondiformes portadoras de sementes que se distribuem do Devoniano superior ao Cretáceo inferior.

Stewart \& Rothwell (1993) separaram muitas plantas tradicionalmente incluídas na Ordem Pteridospermales em suas próprias ordens tais como: Glossopteridales, Caytoniales (incluindo Caytoniaceae Corytospermaceae e Peltaspermaceae). Retiveram dentro da Ordem Pteridospermales apenas as plantas mais antigas e possivelmente mais primitivas dentre as plantas com sementes, bem como seus descendentes imediatos. Assim estariam ainda incluídas as plantas com pré-óvulos do Devoniano superior (como Elkissia polymorpha), plantas com protosteles acanalados do Carbonífero inferior (tais como Diplopteridium, Tristichia e Tetrastichia) e as famillias Lyginopteridaceae, Calamopityaceae, Medullosaceae e Callistophytaceae, todas do Paleozóico superior.

O gênero Botrychiopsis Kurtz 1895a apud Archangelsky \& Arrondo, 1971 foi considerado por Archangelsky \& Arrondo 1971 como morfogênero de posição sistemática incerta, após ressaltarem que suas frondes não foram ainda encontradas férteis, seja portando esporângios que estabelecessem sua afinidade botânica com Filicopsidas ou Progymnospermopsidas, seja portando frutificações com óvulos/sementes/grãos de pólen que as classificassem como Gymnospermopsida - Ordem Pteridospermales. Porém, o fato de não ter aspecto de frondes filicopsidas paleozóicas as distancia de afinidades com aquela primeira classe. Por outro lado, há alguns aspectos que sugerem afinidades de Botrychiopsis com Pteridospermales: a) o aspecto odontopterídeo de algumas de suas pínulas; b) associação fossilífera de Botrychiopsis weissiana com frutificações masculinas do tipo Pteruchus (sem união orgânica, contudo); esses dois aspectos apontados por Archangelsky \& Arrondo (1971) e c) suas características epidérmicas (estômatos haplocélicos) sugerindo forte afinidade gimnospérmica, conforme Maithy (1965), Artabe et al. (1987) sugeriram para Botrychiopsis e estruturas reprodutivas 
associadas uma vinculação com Pteridospermas, como possivel estoque ancestral das Coristospermae.

A classificação taxonômica do Gênero Botrychiopsis em Phylum Gymnospermae (?) é adotada em Archangelsky \& Cúneo (1981) enquanto Cesari \& Garcia (1988) se referem a esse gênero dentro de Pteridospermophyta(?). Mantendo, tentativamente, essas afinidades mas adotando a sistemática de Stewart \& Rothwell (1993), consideram-se aqui as Botrichiopsis dentro da Div. Trachaeophyta, Classe Gymnospermopsida (?) e Ordem Pteridospermales (?), indicando com um sinal de interrogação a afinidade incerta.

\section{Gênero Botrychiopsis Kurtz 1895a emend. Archangelsky \& Arrondo, 1971.}

A história desse gênero é longa e complexa. No início, Carruthers (in Plant 1869, PI. V, figs. 2 e 3), estudando espécimes brasileiros provenientes de minas de carvão do Rio Grande do Sul, identificou entre eles uma forma de fronde que descreveu como portando pínulas largas na base, irregularmente lobadas, de ápice obtuso, sendo as pínulas basais grandes, com lobos numerosos e irregulares e veias arqueadamente paralelas e dicotômicas. Com base nela, erigiu a espécie Odontopteris plantiana, depositando seu holótipo no British Museum, sob número V. 228.

Em 1879, estudando espécimes indianos, Feistmantel propôs a criação de gênero e espécie novos (Neuropteris valida) para frondes largas e lineares, pinadas, raque forte, portando pínulas que, na parte inferior da fronde, eram inteiras e mais ou menos de forma semicircular, gradualmente passando a segmentos mais longos e lobados em direção ao ápice.

O morfogênero Botrychiopsis foi erigido por Kurtz (1895, apud Archangelsky \& Arrondo 1971) sob a designação específica $B$. weissiana, para elementos carboníferos argentinos que representavam um estágio morfológico de fronde intermediário entre os típicos gêneros monopinados e bipinados. Contudo, tratavase de fragmentos de frondes incompletos, interpretados por ele como "pínulas 
trilobuladas" ainda conforme Archangelsky \& Arrondo (1971). Manteve, entretanto, o nome Neuropteridium validum (Feistmantel) Feistmantel para as formas permianas argentinas em Kurtz (1895 apud Archangelsky \& Arrondo 1971), sem qualquer menção à semelhança entre $B$. weissiana e $N$. validum.

Foi Arber (1905) quem propôs a reunião das frondes brasileiras de Carruthers (in Plant 1869), com as indianas de Feistmantel (1879) e as permianas argentinas de Kurtz (1895 apud Archangelsky \& Arrondo 1971) sob uma única designação: Neuropteridium validum (Feistmantel) Feistmantel, dando prioridade ao epiteto validum sobre o epíteto plantianum, argumentando com esse procedimento evitar confusões, como já fora feito por Seward (1903) ao descrever material sul-africano eopermiano.

Em 1927, Gothan propôs uma nova designação genérica Gondwanidium para as formas gondvânicas, retendo Neuropteridium para formas triássicas européias. Entretanto, só em 1941, define melhor o primeiro gênero reconhecendo duas espécies: G. plantianum (considerando a prioridade de O. plantiana Carr. sobre $N$. validum Feistm.) e G. sibiricum (Petunnikov) de Angara.

Neuburg (1948 apud Archangelsky \& Arrondo 1971), além de dar uma diagnose para o gênero Gondwanidium incluiu nele duas espécies angáricas: $G$. sibiricum (Petunnikov) e G. petiolatum Neuburg. Descreveu também frutificações presas bilateralmente à raque que portava pínulas de Gondwanidium, sugerindo sua classificação entre as pteridospermas.

No Brasil, Dolianiti (1953, Fig. 1) ilustrou como Gondwanidium plantianum porções de pinas contendo pínulas subcirculares, de base catadrômica e decorrente, provenientes de sedimentos considerados do Carbonífero superior do Subgrupo Itararé, em Acampamento Velho, no Rio Grande do Sul. O material brasileiro confirma sua identidade com 0 material bipinado da Argentina, conforme Archangelsky \& Arrondo 1971.

Nessa ocasião, Dolianiti ressaltou a ocorrência única de Gondwanidium no Subgrupo Itararé do Rio Grande do Sul, e o desconhecimento desse gênero, até então, nas porções mais setentrionais da bacia do Paraná. 
Maithy (1965), ao propor a espécie Gondwanidium indicum para espécimes provenientes do Andar Karharbari (Permiano inferior) da Índia, o fez com base em compressões que por suas características epidérmicas (estômatos haplocélicos) sugeriram fortemente uma afinidade gimnospérmica (isto é, pteridospérmica) para essas formas. Distinguiu essa espécie das espécies $G$. validum e $G$. plantianum pelos seguintes caracteres: em $G$. validum, as pínulas sésseis são menos lobadas e aderidas à raque pela região basal completa, seus ápices são amplamente arredondados, e enquanto em G. plantianum as pínulas são profundamente incisas de base um pouco alongada (quase como um peciolo curto) e de ápice arredondado mas algo agudo.

Surange (1966), em sua síntese das pteridófitas fósseis indianas, refere-se a G. validum (Feistm.) Gothan e a Gondwanidium $\mathrm{sp}$. entre as frondes filicofíticas paleozóicas que apresentariam características epidérmicas. Ambas as formas seriam provenientes do nível Karharbari.

Archangelsky \& Arrondo (1971), revisando exemplares originais de Kurtz e de Frenguelli, priorizaram o gênero Botrychiopsis sobre o gênero Gondwanidium, distinguindo três espécies gondvânicas de Botrychiopsis: $B$. weissiana, B. plantiana e $B$. valida. A espécie Gondwanidium sibiricum é a única espécie que permanece, apesar de acreditarem tratar-se também do mesmo gênero Botrychiopsis mas, por não poderem observar o material original na ocasião, deixaram de propor uma nova combinação.

No Carbonífero superior da Austrália, Rigby (1985) registrou a presença da espécie Botrychiopsis ovata (McCoy) Rigby 1985.

Em 1989, revendo frondes pteridospérmicas do Gondwana, Rigby considerou as presenças, no Paleozóico superior desse continente, de Bergiopteris Kurtz 1921 ex. Archangelsky 1977, para frondes monopinadas, e de Botrychiopsis Kurtz 1895, para frondes bipinadas, relacionando para o Carbonifero superior as seguintes espécies: Bergiopteris insignis Kurtz 1921 ex Archangelsky 1977; Botrychiopsis weissiana Kurtz 1895 e Botrychiopsis plantiana (Carr.) Archangelsky \& Arrondo 1971. Para o Permiano inferior registrou: Bergiopteris archangelskyi Rigby 1989 e 
Bergiopteris andersoni Rigby 1989, além de Botrychiopsis valida (Feistm.) Archangelsky \& Arrondo 1971, Botrychiopsis indica Maithy 1965 e B. ovata (McCoy) Rigby 1984.

No Brasil, o gênero Botrychiopsis foi registrado como tal, pela primeira vez na literatura geológica, por Millan (1975), ao caracterizar a tafoflora carbonífera de Monte Mor onde relacionou as espécies $B$. cf. B. plantiana e B. cf. B. weissiana em níveis do Subgrupo Itararé do Estado de São Paulo. Contudo, a descrição dos espécimes ai identificados foi realizada somente em Millan (1979), ao revisar o material estudado em sua tese de doutorado (Millan 1972), ressaltando sua associação com Rhacopteris em níveis de floras pré-glossopterídeas.

Andreis et al. (1980) descreveram e figuraram pínulas isoladas de Botrychiopsis weissiana (Est. I, Fig. 6), para o Subgrupo Itararé do Rio Grande do Sul, na tafoflora da fazenda Goulart, Francisquinho, Município de São Jerônimo, RS.

No mesmo ano, Cazzulo-Klepzig et al., numa análise mais detalhada das associações paleoflorísticas do Subgrupo Itararé, no Rio Grande do Sul, confirmaram as presenças de $B$. plantiana e $B$. sp. nos afloramentos de Acampamento Velho e fazenda Goulart sendo no primeiro jazigo associadas a Cordaites sp., protoglossopterídeas e glossopterídeas e no segundo, associadas apenas a Cordaites sp. e a protoglossopterídeas (Rubidgea).

Guerra-Sommer \& Cazzulo-Klepzig (1981), citando o trabalho anterior (Cazzulo-Klepzig et al. 1980), provavelmente num lapso, referiram-se a B. piantiana como ocorrendo no afloramento Faxinal e não nos afloramentos acima mencionados.

Em 1986, Pasqualini et al. registraram a presença de Botrychiopsis em alguns níveis de um afloramento da porção basal da Formação Rio Bonito, na área de Mariana Pimentel, Guaíba, RS. O gênero, ai, aparece associado a Glossopteris, Gangamopteris, Phyllotheca, Buriadia, Scutum numa assembléia tipicamente eopermiana.

Estudando com mais detalhe esse material, Guerra-Sommer et al. (1986) descreveram Botrychiopsis plantiana para esses níveis basais da Formação Rio Bonito, no Morro Papaleo, área de Mariana Pimentel. 
Em 1987b, mais uma vez Millan registrou a presença do gênero Botrychiopsis no Estado de São Paulo, identificando e figurando a espécie B. plantiana (Carr.) Archangelsky \& Arrondo 1971, na tafofiora da Fazenda Santa Marta, em Itapeva. A presença dessa espécie é aqui confirmada à luz da revisão de sua coleção e de novos elementos coletados.

\section{Botrychiopsis plantiana (Carruthers) emend. Archangelsky \& Arrondo} 1971

\section{Est.3, Fig.7; Est.4, figs.1-4; Est.5, figs.1-3; Est.6, figs.1, 2 e 4; Est.8, figs.1 e 3; Est.9, figs.1 e 3}

Espécimes Identificados: GP/3E 8896, 8814, 8917, 8944, 8952-A, 8953A, 9027B; MNUFRJ-1843Pb, 1845PbA e B, 1848Pb, 1850Pb, 1852Pb .

\section{Descrição}

Fragmentos mediano-apicais de frondes longas, bipinadas nas porções mais proximais, tendendo a monopinadas nas porções distais. Contorno da porção mediano-apical triangular, com raque principal robusta (de $5 \mathrm{~mm}$ de diâmetro na região proximal afilando distalmente), com fortes estrias longitudinais, portando, em fragmentos mediano-proximais, raques de segunda ordem, mais estreitas $e_{1}$ também, estriadas longitudinalmente. A filotaxia de suas pinas é de disposição alterna nas porções mais basais, tendendo a suboposta nas porções mais distais, em ângulo variável de pouco agudo $\left(70^{\circ}\right)$ a muito agudo $\left(45^{\circ}\right)$ no sentido de proximal para distal. As pinas são simples a compostas, considerando o grau de incisão dos lobos, gerando diferenciação ou indiferenciação das pínulas de contorno ovado e com imbricação e/ou proximamente colocadas.

As pinas da região basal-mediana da fronde são de contorno ovado a subcircular, alongando-se e lobulando-se até formar pínulas profundamente incisas, juntas a levemente imbricadas. As pinas são subopostas em ambos os lados da ráquis com ângulos de $45^{\circ}-70^{\circ}$. 
As pinas, na região mediana da fronde, são mais longas que largas $(30 \mathrm{~mm} x$ $20 \mathrm{~mm}$ ), de forma lanceolada, com suas cinco a sete pínulas profundamente divididas, sendo a primeira pínula catadrômica, mais subcircular, enquanto as outras se tornam mais alongadas até terminar numa pínula apical meio espatulada a ligeiramente aguda.

No setor superior da fronde, as pinas tendem a tornar-se subpostas a subalternadas, a raque adelgaça-se até desaparecer na pínula apical. As pinas vão tornando-se menos lobuladas, isto é, com pínulas menos individualizadas. Assim, notam-se formas trilobadas passando distalmente a não-lobuladas e espatuladas.

A venação pinular é, sucessivamente ou até três vezes, dicotômica a partir da base ou da raque diferenciada na pina. É densa e suavemente curvada para a margem.

Tratando-se de material muito fragmentado, passa-se a uma descrição de cada espécime em vez de generalizar principalmente as medidas.

O exemplar GP/3E 8952-A (Est.8, Fig.1) corresponde a um fragmento de pina quase completo, de forma elíptica a subtriangular ampla, medindo $33 \mathrm{~mm}$ de largura por $36 \mathrm{~mm}$ de comprimento. A pina é composta por cinco pínulas fragmentadas de margem inteira, de disposição suboposta em ângulos próximos a $45^{\circ}-60^{\circ}$, às vezes imbricadas, amplamente decorrentes e insertas por quase toda largura da base. A raque da pina é bem definida entre as pínulas proximais tornando-se distalmente pouco evidente. As pínulas, em sua borda catadrômica, podem permanecer levemente imersas no sedimento devido a uma leve torsão.

As pinulas basais são mais ou menos equidimensionais de forma subtriangular a subcircular, com $17 \mathrm{~mm}$ de largura por $14 \mathrm{~mm}$ de comprimento. As pínulas laterais superiores são ovais a subcirculares medindo $13 \mathrm{~mm}$ de comprimento preservado por $12-13 \mathrm{~mm}$ de largura.

A pínula apical tem forma espatulada com sua porção distal expandida, algo lobulada, medindo $13 \mathrm{~mm}$ de largura por $15 \mathrm{~mm}$ de comprimento. As venações são de calibre uniforme e se dicotomizam, até três vezes, em ângulos agudos, encurvandose antes de alcançar a borda da pínula. 
O espécime GP/3E 8953A (Est.3, Fig.7) é um fragmento de pina de forma triangular alargada, medindo $12 \mathrm{~mm}$ de largura por $24 \mathrm{~mm}$ de comprimento. Possui quatro pínulas laterais quase completas, presas por toda a lâmina basal (base de inserção larga), uma pínula mais basal muito fragmentada e uma apical quase completa. As pínulas medem $6-10 \mathrm{~mm}$ de largura por $10-15 \mathrm{~mm}$ de comprimento, apresentando venações pouco nítidas mas que se dicotomizam três vezes, encurvando-se suavemente para a borda do limbo.

Fragmento de pina quase completo, o espécime GP/3E 9027B (Est.9, Fig.1) apresenta comprimento preservado de $24 \mathrm{~mm}$ e largura de $22 \mathrm{~mm}$ em forma amplamente elíptica com pínulas apecioladas, unidas por quase toda a base (base larga de inserção), mostrando cinco pínulas fragmentadas, sendo a pínula apical aparentemente obovada. Essas pínulas medem 9-10mm de largura por $10-14 \mathrm{~mm}$ de comprimento. Suas veias, pouco visíveis, dicotomizam-se três vezes e encurvase levemente em direção à borda do limbo.

O exemplar GP/3E 8896 (Est.6, Fig.2) é a impressão de um fragmento de pina medindo $30 \mathrm{~mm}$ de largura por $32 \mathrm{~mm}$ de comprimento. Sua forma é oblonga, com pínulas apecioladas, unidas por quase toda a base (base larga de inserção). Possuem três pínulas quase completas todas inseridas do mesmo lado da pina. A pínula apical está extremamente fragmentada, não sendo possível determinar sua forma.

As pinulas medem entre $7-10 \mathrm{~mm}$ de largura por $11-14 \mathrm{~mm}$ de comprimento. Suas venações, pouco visiveis, são três vezes dicotômicas, decorrentes próximos à raque da pina, alongando-se até a margem.

Fragmento de pina medindo $26 \mathrm{~mm}$ de largura por $29 \mathrm{~mm}$ de comprimento, o exemplar GP/3E 8914 (Est.6, Fig.4) possui forma amplamente oblonga, com pínulas apecioladas, unidas por quase toda a base (base larga de inserção). Porta quatro pínulas, sendo a apical quase completa e de forma espatulada e as três laterais mais fragmentadas, possuem formas mais subcirculares. As pínulas medem $9-11 \mathrm{~mm}$ 
de largura por $13-15 \mathrm{~mm}$ de comprimento. As venações apresentam-se pouco visíveis, observando-se dicotomias e leve encurvamento para a borda do limbo.

O espécime GP/3E 8917 (Est.5, Fig.2) é um fragmento de pínula quase completo, de forma espatulada, com sua porção distal expandida tendendo à lobulação. Seu contorno é liso e possui comprimento preservado de $19 \mathrm{~mm}$ e largura de $18 \mathrm{~mm}$. Sua venação é de calibre uniforme cobrindo todo o limbo, dicotomiza-se até três vezes, em ângulos agudos, encurva-se levemente antes de alcançar a borda da pínula.

O exemplar GP/3E 8944 (Est.8, Fig.3) é um fragmento quase completo de pina, apresentando forma amplamente elíptica a subtriangular, com comprimento preservado de $43 \mathrm{~mm}$ e $30 \mathrm{~mm}$ de largura. Está composta por sete pínulas, sendo as quatro mais proximais fragmentadas de margem inteira, subopostas, com ângulo de inserção próximo a $45^{\circ}-60^{\circ}$, às vezes imbricadas e amplamente decorrentes. As três pínulas mais distais estão muito fragmentadas ou encobertas por outras impressões, porém se pode observar sua disposição oposta na raque da pina em ângulos próximos a $45^{\circ}$. Existe uma leve torsão de suas pínulas em sua margem catadrômica, podendo permanecer escondida no sedimento.

As pínulas laterais inferiores são ovais a subcirculares com $10-11 \mathrm{~mm}$ de largura por $13-15 \mathrm{~mm}$ de comprimento. A pínula lateral mediana é subcircular medindo $17 \mathrm{~mm}$ de largura por $19 \mathrm{~mm}$ de comprimento e a pínula apical é de forma espatulada, às vezes, lobulada, medindo $10 \mathrm{~mm}$ de largura por $15 \mathrm{~mm}$ de comprimento. As venações são de calibre uniforme e se dicotomizam em ângulos agudos até três vezes, encurvando-se levemente para alcançar a borda da pínula.

Os demais espécimes acima identificados, pertencentes à Coleção da tafoflora Santa Marta depositados no Museu Nacional, foram minunciosamente descritos por Millan (1987a). Foram excluídos dessa espécie os indivíduos MN/RJ $1842 \mathrm{~Pb}$; $1844 \mathrm{~Pb}$; $1846 \mathrm{~Pb}$; $1849 \mathrm{~Pb}$; $1851 \mathrm{~Pb}$; $1853 \mathrm{~Pb}$; $1854 \mathrm{~Pb}$ e $1855 \mathrm{~Pb}$ que serão tratados à parte. 


\section{Comparação}

Millan (1987b) identificou e descreveu como Botrychiopsis plantiana os espécimes provenientes de Itapeva (SP) e depositados no Museu Nacional do Rio de Janeiro, sob os números: 1843Pb; 1845PbA e $\mathrm{B} ; 1847 \mathrm{~Pb} ; 1848 \mathrm{~Pb} ; 1850 \mathrm{~Pb}$; $1852 \mathrm{~Pb}$.

Ao fazer a revisão dos espécimes da tafoflora Santas Marta atribuíveis ao gênero Botrychiopsis, examinando aqueles depositados nas coleções científicas do Museu Nacional do Rio de Janeiro e do IGc/USP, conclui-se que, se excetuando os espécimes de números 1842Pb; 1844Pb; 1846Pb; 1849Pb; 1851Pb; 1853Pb; $1854 \mathrm{~Pb}$ e 1855Pb, figurados em Millan (1987b, Est. I, figs.1, 3 e 5; Est. II, Fig.2 e 4; Est. III, Fig. 1-3), todos os demais podem ser identificados como possuidores dos caracteres propostos na diagnose emendada por Archangelsky \& Arrondo (1971).

Ao comparar os espécimes da coleção estudada àqueles identificados como B. plantiana por Millan (1979, Est, I, Fig. 6 - 8), provenientes do sítio da Mina, em Monte Mor (SP), dado o grau de fragmentação extremo dos espécimes dessa localidade, verificam-se apenas similaridades de algumas características das pínulas tais como venação dicotomizante arqueadamente paralela, lobação irregular do limbo pinular e imbricação pinular.

Comparando os exemplares de Itapeva (SP) com os espécimes figurados por Guerra-Sommer \& Cazzulo-Klepzig (1981, Est.I, Fig. 1 e 2) provenientes da fazenda Goulart, Francisquinho, Município de São Jerônimo, no Rio Grande do Sul, observam-se semelhanças quanto à forma das pínulas subcirculares, imbricadas e de margens irregularmente lobadas bem como, quanto a venação sucessivamente dicotômica e suavemente encurvada até a borda do limbo .

Apesar do caráter fragmentar das frondes presentes no material procedente de Itapeva, de ambas as coleções estudadas, ao compará-las com material argentino de B. plantiana procedente de Bajo de los Vélez, San Luiz, depositado na Coleção Científica da Universidade de Buenos Aires e também com as características diagnósticas e figuradas em Archangelsky \& Arrondo (1971, lám.V, figs. 1,2 e lám.VI, figs. 1 - 3) chega-se à conclusão que poderiam corresponder à 
mesma espécie, destacando-se os seguintes aspectos morfológicos: pínulas próximas a base da fronde de forma subcircular com ampla base de inserção; inserção não torsionada de pinas na raque (1847Pb, Est.4, Fig.3); pínulas na porção mediana levemente imbricadas a juntas (1852Pb Est. 4, Fig.4, 1843Pb, Est.3, Fig.7); número de pínulas por pina mediana embora não preservada completamente podese inferir maior que sete; comprimento máximo da pina, menor que 60mm; ângulo de inserção das pinas entre $45^{\circ}$ e $70^{\circ}$; tamanho das pínulas não excedendo $15 \mathrm{~mm} \times$ $20 \mathrm{~mm}$ e pínula apical da fronde espatulada com margem distal arredondada; venação densa, cobrindo uniformemente todo o limbo, repetidamente dicotômica, decorrente na base e encurvada até a margem, desprovida de um feixe mediano bem marcado.

Essas similaridades morfológicas permitem registrar com certo grau de segurança a presença de Botrychiopsis plantiana na tafoflora Santa Marta ainda que em níveis mais antigos com relação a suas ocorrências em outras áreas gondvânicas.

Sua distribuição estratigráfica iniciar-se-ia no Carbonífero superior (Westfaliano) do Subgrupo Itararé de Monte Mor e Itapeva, até o Permiano Formação Vryheid (Ecca médio) no Transaal isto é, desde Neocarbonífero até Eopermiano.

\section{Gênero Eusphenopteris Novik 1947}

Segundo White (1990), três formas de pteridospermas primitivas dominaram no período Carbonífero médio a superior do Gondwana: Nothorhacopteris (=Rhacopteris), Botrychiopsis e Dactylophyllum. Elas representam extremidades opostas de uma série de formas a partir de um tipo de frondes com pínulas grandes, variavelmente, lobadas até um tipo com pínulas profundamente dissecadas e entre esses uma série de formas intermediárias. Assim, entre Botrychiopsis e Dactylophyllum, conforme aquela autora, haveria uma série de formas intermediárias, podendo representar híbridos entre ambas e cuja delimitação em morfogêneros é difícil de ser feita. Entre essas formas pteridospérmicas, encontra-se 
também, o gênero Eusphenopteris Novik, ai colocado graças a sua associação com Calymnotheca sp.

Isso está de acordo com Cúneo (1990), quando afirma que as partes apicais das pinas e segmentos de pinas de Eusphenopteris Novik são semelhantes àqueles de outros gêneros gondvânicos como Botrychiopsis (Kurtz) Archangelsky \& Arrondo, Fedekurtzia Archangelsky e ainda Nothorhacopteris Archangelsky.

Sem dúvida, o caráter tripinado/tetrapinado, e a morfologia particular das pínulas arredonda ou redondo-lobadas, inteiras, bilobadas ou trilobadas, com venaçào aberta dicotômica, flabelinérvea apartir de uma veia basal de Eusphenopteris diferenciam esse gênero claramente de Sphenopteris, com o qual foi confundido por longo tempo (Van Ameron 1975 apud Cúneo 1990) e de outros gêneros gondvânicos supracitados. Difere também de Triphyllopteris Schimper pelas características diferentes de suas pínulas.

$\mathrm{Na}$ assembléia estudada, as formas Nothorhacopteris, Botrychiopsis e Eusphenopteris podem ser bem caracterizadas, embora, inicialmente tenha sido difícil de detectar a distinção entre Botrychiopsis e Eusphenopteris.

\section{cf. Eusphenopteris sp.}

Est. 5, figs. 4 e 5; Est. 6, figs. 1 e 3; Est. 7, Fig.1; Est. 8, Fig. 2 e Est. 9, Fig. 2

\section{Sinonímia:}

1987- Botrychiopsis plantiana (Carr.) Archangelsky \& Arrondo 1971, Millan p.811-818, Est.1, figs. 1, 3 e 5; Est.II, Fig.2 e 4; Est.Ill, Fig.1, 2 e 3; non Est.I, Fig.2, 4, 6,7 ; Est.II, 1 e 3.

Espécimes identificados: MN/RJ- 1842Pb; 1844Pb; 1846Pb; $1849 \mathrm{~Pb}$; $1851 \mathrm{~Pb} ; 1853 \mathrm{~Pb} ; 1854 \mathrm{~Pb} ; 1855 \mathrm{~Pb}$.

\section{Descrição}

Os espécimes constituem impressões de fragmentos de fronde medianodistais, com tamanho moderado: $35-70 \mathrm{~mm}$ de comprimento por $15-45 \mathrm{~mm}$ de largura. 
A fronde tripinada ou tetrapinada apresenta raque principal da fronde forte ou robusta (3-7mm de largura), acanelada e estriada longitudinalmente, flexuosa ou de caráter algo simpodial. Em alguns casos, foram preservadas apenas raques de pina $(1855 \mathrm{~Pb})$, mais estreitas $(0,5-1,5 \mathrm{~mm}$ de largura) igualmente, flexuosas, acaneladas e estriadas longitudinalmente e que, também, são encontradas inseridas, organicamente, nas raques secundárias/terciárias de frondes. As pinas estão alternadamente sobre as raques secundária/terciária alada, flexuosa, de 1-4mm de largura com inserção das pinas a ângulo variável de muito agudo a quase reto.

As pinas de maior tamanho tem $10-17 \mathrm{~mm}$ de comprimento e $10-18 \mathrm{~mm}$ de largura. As pinas são de estruturas bipinadas e de contorno arredondado-lobado, base constricta, com até cinco pínulas na última pina. As pínulas arredondadas, bilobuladas ou trilobuladas são quase sempre basiscópicas, medindo cerca de $8 \mathrm{~mm}$ de largura por $10 \mathrm{~mm}$ de comprimento.

A venação pinular é aberta flabelinérvea sucessivamente, dicotômica a partir da base da raque diferenciada da pina, densa e suavemente curvada para a margem lateral.

O exemplar 1842Pb (Est.7, Fig.1) é uma fragmentada fronde de região mediana. Mede $70 \mathrm{~mm}$ de comprimento por $45 \mathrm{~mm}$ de largura. Sugere ser de uma fronde, no minimo, tripinada. A raque de fronde é relativamente forte $(3 \mathrm{~mm}$ de largura), flexuosa (quase simpodial), longitudinalmente acanelada e estriada. Partem dela quatro raques de pinas, em disposição alterna, menos robustas, acaneladas e estriadas, emergindo a ângulos pouco agudos a quase retos. A terceira pina de baixo para cima é portadora de duas pínulas reniformes a flabeliformes e muito incompleta que medem aproximadamente $16 \mathrm{~mm}$ de largura máxima por $12 \mathrm{~mm}$ de altura. Há uma tendência à lobulação e a venação é sucessivamente dicotômica, densa, e curvada suavente para as margens laterais.

O exemplar 1844Pb (Est.9, Fig.2) é uma raque de fronde fragmentada correspondendo à região médio-distal. Mede $60 \mathrm{~mm}$ de comprimento por $7 \mathrm{~mm}$ de largura. É forte, algo flexuosa, acanelada e estriada longitudinalmente, portando uma raque de pina de 3 a $4 \mathrm{~mm}$, à esquerda e superiormente, em inserção angular 
pouco aguda e sem pina preservada. Sobreposta à ela, e em suas proximidades, existem pinas e pínulas sem qualquer conexão.

O exemplar 1846Pb (Ets.6, Fig.1) é um fragmento de pina apresentando uma raque alada, flexuosa, donde partem cinco pínulas arredondadas a rômbicas numa disposição alterna e de nervação flabelinérvea, dicotômica e densa. As pínulas acroscópicas inserem-se a um ângulo relativamente agudo e medem mais ou menos $8 \mathrm{~mm}$ de comprimento por $7 \mathrm{~mm}$ de largura. A venação está pobremente preservada.

O espécime 1849Pb (Est.5, Fig.4) é um fragmento da porção mediana de fronde tripinada/tetrapinada, medindo $40 \mathrm{~mm}$ de comprimento por aproximadamente $30 \mathrm{~mm}$ de largura.

Apresenta uma raque de fronde relativamente forte ( $3 \mathrm{~mm}$ de espessura), estriada longitudinalmente, portando duas raques de pinas em disposição alterna e com inserção angular aguda. As raques das pinas são menos robustas, mas igualmente estriadas longitudinalmente. A pina esquerda mede $25 \mathrm{~mm}$ de comprimento por $20 \mathrm{~mm}$ de largura, apresenta três pínulas muito fragmentadas, duas laterais e uma apical, individualizada a pouco individualizadas tendendo a uma lobulação.

A pina direita está fragmentada e levemente deslocada de sua posição original, apresenta uma pínula mais completa e visivel flabeliforme tendendo a lobulação. A venação, apesar de pobremente preservada, quando submetida a óleo de parafina permite observar que é dicotômica e levemente arqueada até as bordas laterais do limbo.

O exemplar 1851Pb (Est.8, Fig.8) é um fragmento de fronde tripinada/tetrapinada, medindo $35 \mathrm{~mm}$ de comprimento por $25 \mathrm{~mm}$ de largura. A raque principal é robusta $(5 \mathrm{~mm}$ de largura), acanelada, flexuosa e estriada longitudinalmente. Apresenta, à sua esquerda e superiormente, a inserção de uma raque secundária menos robusta ( $2 \mathrm{~mm}$ de largura), mas igualmente estriada e acanelada longitudinalmente, em inserção angular quase reta. Ela é portadora de um fragmento de raque de pina de disposição quase perpendicular. A pina está 
muito fragmentada em quase toda o seu contorno, mostrando apenas uma parte basal à esquerda da qual parte uma pínula basal flabeliforme e catadrômica.

O espécime 1853Pb (Est.6, Fig.3), impressão de fronde tripinada/tetrapinada fragmentada medindo $47 \mathrm{~mm}$ de comprimento por $15 \mathrm{~mm}$ de largura, com o caráter pinado indistinto. A raque principal da fronde é relativamente forte ( $4 \mathrm{~mm}$ de largura), acanelada e estriada longitudinalmente, e ela insere-se, à esquerda e superiormente, uma raque secundária de fronde menos robusta ( $3 \mathrm{~mm}$ de largura) e, igualmente, canelada e estriada longitudinalmente, com um ângulo pouco agudo, sendo portadora, pelo menos, de duas pínulas muito incompletas inseridas a ângulos pouco agudos.

As pinas estão muito fragmentadas, mas é visível uma tendência à lobulação na da esquerda, bem como uma venação sucessivamente dicotômica e curvada para a margem.

O exemplar $1854 \mathrm{~Pb}$ (Est.5, Fig.3) é uma pina apical com raque robusta, flexuosa medindo $20 \mathrm{~mm}$ de comprimento por $12 \mathrm{~mm}$ de largura. Porta cinco pínulas sendo a maior a proximal ( $5 \mathrm{~mm}$ de comprimento por $7 \mathrm{~mm}$ de largura) que possui forma bilobada. As três segundas são ovóides e basiscópicas. A mais distal ligeiramente rombóide. A venação flabelinérvea.

O exemplar $1855 \mathrm{~Pb}$ (Est.5, Fig.5) corresponde a um fragmento de pina medindo $65 \mathrm{~mm}$ de comprimento por $30 \mathrm{~mm}$ de largura, da região médio-distal. Não foi possivel observar a raque principal da fronde, mas, apenas, as raques secundárias e terciárias da fronde, caracterizando seu caráter tripinado/tetrapinado. $E$ isto, é confirmado pelo caráter pouco robusto da raque e pela inserção das raques de pínulas. Há uma estreita, canelada e estriada longitudinalmente. Nela inserem-se seis raques de pinas: duas basais e uma apical, em disposição alterna e com inserção angular variando de muito aguda a muito aguda $\left(40^{\circ}\right.$ a $\left.70^{\circ}\right)$. As raques das pínulas são curtas, estreitas e, visivelmente, diferenciadas do setor proximal ao setor médio-distal, onde perdem esta característica. As pínulas são de contorno ovado. A base de inserção das pínulas nas raques das pinas é, geralmente, ampla e alada, a 
sua venação é, sucessivamente, dicotômica a partir da base pinular ou da raque diferenciada da pina, densa e suavemente curvada para a margem.

\section{Comparação}

Ao fazer a revisão dos espécimes da tafoflora Santa Marta atribuível ao gênero Botrychiopsis foram examinados aqueles depositados nas coleções científicas do Museu Nacional do Rio de Janeiro e do IGc/USP. Concluiu-se então, que os espécimes de números GP/3E- 8896, 8814, 8917, 8844, 8952A, 8953A, $9027 \mathrm{~B}$ e MN/UFRJ- 1843Pb; 1845PbA e $\mathrm{B} ; 1847 \mathrm{~Pb} ; 1848 \mathrm{~Pb} ; 1850 \mathrm{~Pb}, 1852 \mathrm{~Pb}$, pertencem a $B$. plantiana, enquanto que os espécimes de números: MN/UFRJ$1842 \mathrm{~Pb} ; 1844 \mathrm{~Pb} ; 1849 \mathrm{~Pb} ; 1851 \mathrm{~Pb} ; 1853 \mathrm{~Pb}$; 1854Pb; 1856Pb; $1855 \mathrm{~Pb}$, são melhor identificados dentro do gênero Eusphenopteris, sendo possuidores dos caracteres propostos na diagnose diferencial de Gastaldo \& Boersma (1983) e dos caracteres diagnósticos apresentados na descrição de Cúneo (1990).

Essas formas sugerem constituir partes de possíveis frondes tripinadas (hipotéticas), na qual é provável que a raque, principalmente, de grande calibre (espécime $1842 \mathrm{~Pb}$ ) com $45 \mathrm{~mm}$ de largura, seja a porção mais basal, portando pinas bipinadas. Infelizmente, as formas de pinas mais simples atribuídas à base, isto é, à parte mais proximal da fronde típica desse gênero, não foram preservadas aqui. Contudo, o grande tamanho das pínulas e a raque muito robusta são possíveis de ser verificadas. Também se pode verificar as pínulas mediano-basais de contornos reniformes, apresentando modo de inserção perpendicular e pseudopeciolado, com uma proporção comprimento por largura de 1:1. Por outro lado, os espécimes MN/UFRJ 1855Pb e MN/UFRJ 1849Pb constituem porções medianas e o espécime MN/UFRJ 1854Pb uma porção de pina apical dessa possivel fronde hipotética.

Pelas características diagnósticas: a) fronde tripinada/tetrapinada; b) raque principal da fronde forte ou robusta, canelada ou estriada longitudinalmente; c) pinas dispostas alternadamente sobre uma raque alada e flexuosa; d) nervação densa, dicotômica e flabelinérvea destaca-se a possibilidade desses espécimes serem Botrychiopsis ou Sphenopteris. Essas mesmas características aproximam-nos do 
gênero Eusphenopteris Novik. Todavia, considera-se aqui como cf. Eusphenopteris $\mathrm{sp}$., dada a falta de espécimes mais completos de frondes até o momento.

\section{Gênero Nothorhacopteris Archangelsky 1983}

Em 1847, McCoy descreveu e figurou uma nova planta do Carbonífero da Austrália (New South Wales) designando-a Otopteris ovata. Essa espécie foi considerada sinônimo de Rhacopteris inaequilatera Goeppert por Feistmantel 1879. Posteriormente, foi designada Aneimites ovata (McCoy) por Arber (1902) e recombinada como Rhacopteris ovata (McCoy) por Walkom (1934). Rigby (1973) propôs o novo gênero Pseudorhacopteris com a espécie-tipo $P$. ovata, cujo holótipo era o espécime original de McCoy, dado a forma gondvânica apresentar algumas linhas finas entre as veias das pínulas, feições essas ausentes nas Rhacopteris européias.

Retallack (1980) com base no aspecto bipinado da fronde do holótipo, sinonimizou-o dentro de Botrychiopsis valida, incluindo informalmente, as formas monopinadas de R. ovata em "Otopteris" argentinica Geinitz.

Otopteris argentinica foi proposta em 1876 por Geinitz, para designar frondes provenientes de Província de La Rioja, Bacia de Paganzo, Argentina.

Archangelsky (1983), propôs o novo nome genérico Nothorhacopteris para frondes monopinadas das áreas gondvânicas designadas anteriormente Otopteris ovata McCoy ou Rhacopteris ovata (McCoy) Walkom e Otopteris argentinica Geinitz. Assim procedeu devido aos seguintes fatos: a) o holótipo de Rhacopteris ovata (McCoy) Walkom/Pseudorhacopteris ovata (McCoy) Rigby como uma fronde bipinada deveria entrar em sinonímia do gênero Botrychiopsis, portanto, um novo holótipo monopinado deveria ser designado; b) o gênero Otopteris Lindley \& Hutton havia sido colocado em sinonímia com Otozamites Braum; c) assim, a espécie Otopteris argentinica Geinitz, que havia envolvido inclusive os espécimes monopinados de Otopteris ovata McCoy, deveria ser designado por um novo gênero.

Para caracterizar esse morfogênero, baseou-se em feições tais como: a) mesófilo pinular espesso ou coriáceo; b) frondes monopinadas com pínulas sésseis 
ou de pecíolo curto; c) pínulas triangulares, flabeliformes, cuneadas ou subcirculares, contraídas na base, dispostas no plano da raque com margem distal inteira, serreada ou levemente lobulada; d) venação dicotômica irradiando-se desde a base da pina, uniformes, com estriações intervenosas finas (lineações) de número variável, mais proeminente em pinas maior; e) pinas adjacentes que podem ser ligeiramente imbricadas.

Nothorhacopteris argentinica é considerada um dos elementos mais característicos da Região Paleoflorística Gondvânica, sendo índice da zona megaflorística do Carbonífero médio. Ocorrem na Austrália, Índia e América do Sul.

\section{Nothorhacopteris cf. Nothorhacopteris argentinica (Geinitz)}

\section{Archangelsky 1983}

\section{Est.8, Fig.4}

\section{Espécimes identificados: GP/3E8928A}

\section{Descrição}

A amostra GP/3E8928-A apresenta fragmentos de três pinas isoladas, dispostas caoticamente na porção distal de um fragmento aflebóide.

As pinas pecioladas são subcirculares a flabeliformes, contraídas na base, medindo $12-13 \mathrm{~mm}$ de largura máxima (a $2 / 3$ do ápice) por 12-13mm de comprimento, isto é, numa proporção de 1:1 entre comprimento e largura máxima. Apresentam margens distais inteiras suavemente crenuladas.

A venação é bem visível, de igual calibre $(1 \mathrm{~mm})$ ocupando quase todo o limbo. As veias são retas irradiando-se desde a base da pina, dicotomizando-se até três vezes antes de alcançar a margem distal das pinas.

Também é possivel observar estrias intervenulares descontínuas. Contudo, o aspecto coriáceo das pínulas não é possível verificar devido a seu péssimo grau de preservação. 


\section{Comparação}

Nothorhacopteris cf. $N$. argentinica se separa de $N$. szajnochai (Kurtz, 1921) Azcuy \& Suárez-Soruco 1984 por apresentar: ausência de profundas incisões das pínulas e uma venação radial aberta; de $N$. chubutiana (Archangelsky \& Arrondo 1966) Archangelsky 1983 separa-se por não apresentar veias penetrando na raque da pina e nem 8 a 16 veias por pina e por sua distribuição estratigráfica distinta (Carbonífero inferior-Carbonífero superior); de N. kellaybelenensis Azcuy \& SuárezSoruco 1993 por apresentar margem distal inteira apenas crenulada e também sua venação menos fortemente marcada; de N. major Cúneo 1985 por apresentar pinas cuja proporção largura/comprimento é de 1:1 e também pela sua venação menos flabelinérvea apenas três vezes dicotômica de Anisopteris circularis Doubenger \& Alvárez Ramis 1980 pela presença de estrias típicas. O espécime 8928A apresenta todos os seus carateres morfológicos idênticos aos de N. argentinica (Genitz) Archangelsky 1983. Contudo, a apresentação isolada e a não observação do aspecto coriáceo de suas pinas impedem uma identificação mais completa, obrigando a utilização da nomenclatura Nothorhacopteris cf. Nothorhacopteris argentinica.

\section{Aflébia}

Segundo FontQuer (1985), aflébia é todo órgão foliar, na forma de pinas adventíceas, que nascem na base da raque da fronde isto é, antes das pinas de primeira ordem e de forma distinta dessas. Inicialmente, foram conhecidas no estado fóssil (Aphlebia e outros gêneros) antes das mas alguns fetos viventes também as possuem tais como Hemitelia capensis.

Tem como função proteger e beneficiar a planta em determinados estágios de desenvolvimento, facilitando-Ihe a água visto atuar como condensador de vapor d'água.

As pteridospermas do Carbonífero superior (Nothorhacopteris, Botrychiopsis, Dactylophyllum) são caracterizadas por suas grandes aflébias, na forma de folhas espatuladas ou bractiformes que, provavelmente, teriam um papel protetor, 
envolvendo as frondes pinadas mais delicadas durante o desenvolvimento, conforme ressaltado por White (1990).

Ainda segundo essa autora, a aflébia mostra uma grande variedade de formas, desde folhas grandes indivisas até aquelas em que parte da lâmina é pinada, aproximando-se da fronde normal da planta.

White (1990) chama a atenção ainda para o fato de que as aflébias de forma foliosa são semelhantes em forma e tamanho às folhas de gangamopterídeas do Permiano inferior que aparecem nos interglaciais. Contudo, a venação da aflébia é simples, sem anastomoses entre as veias. Ë possivel que a folha tipo glossopterídea do período seguinte (Permiano) tenha evoluído de um ancestral portador de aflébia, que perdeu a fase pinada de sua fronde sob condições de frio extremo durante a glaciação mais rigorosa. Um salto evolutivo desde venação primitiva até venação reticulada é tudo o que seria necessário.

\section{Aphlebia de Nothorhacopteris cf. N. argentinica (Geinitz) Archangelsky}

1983

\section{Est.10, Fig.1}

\section{Espécime identificado: GP/3E8928B}

\section{Descrição}

O espécime GP/3E8928-B representa a porção basal aflebóide de uma fronde de Nothorhacopteris cf. N. argentinica (Geinitz) Archangelsky 1983, em cuja porção distal, numerosas folnas isoladas dessa fronde estão acumuladas GP/3E8928A descritas anteriormente.

A aflébia apresenta uma forma foliar de aspecto oblongo de $70 \mathrm{~mm}$ de comprimento por $45 \mathrm{~mm}$ de largura. Na região central, possui um espesso feixe de nervuras subparalelas (raque estriada longitudinalmente) de $15 \mathrm{~mm}$ de largura e uma lâmina foliar inteira de margem algo ondulada, na porção proximal, e que tende a se tornar gradualmente dividida, distalmente, com a margem insinuando-se em grandes lobos. Essa lâmina está mais completa do lado direito do feixe foliar mediano. As 
veias mas externas do feixe mediano divergem a um ângulo de $10^{\circ}$ a $20^{\circ}$ durante o primeiro quarto de seu percurso até a margem, encurvando-se a seguir suavemente até um ângulo de $80^{\circ}$ a $85^{\circ}$, em direção à margem. Essas veias de calibre ligeiramente mais grosso próximo ao feixe mediano tornam-se muito finas e numerosas para a margem, após se dicotomizarem três a quatro vezes. As veias têm uma densidade de aproximadamente $20 / 10 \mathrm{~mm}$ na área mediana entre feixe e margem da lâmina e 26 veias $/ 10 \mathrm{~mm}$ na área marginal.

A disposição das pinas é aparentemente oposta, na porção mais distal, onde é possível observar quatro pinas, sendo duas de cada lado. As pinas são nãoindividualizadas a pouco individualizadas, tendendo a uma lobulação.

As pinas são espatuladas a cuneiformes medindo $15 \mathrm{~mm}$ de comprimento por $20 \mathrm{~mm}$ de largura com uma base larga de inserção.

A venação torna-se mais obliqua na parte onde se inicia a pinação. Pode-se observar também a presença de estrias intervenulares, descontínuas.

Pinas isoladas que poderiam estar associadas a esta aflébia recobrem-na na porção distal.

\section{Discussão}

Forma de fronde com aflébia de Dactylophyllum ditatum é exibida por White (1990, foto 105), onde se observa uma raque forte ligada a uma lâmina de margem, ligeiramente, ondulada e venação oblíqua, na porção basal, passando a pinada na porção mais distal.

Também White (1990, foto 109) apresenta uma aflébia que, apartir de um feixe mediano longo, apresenta uma lâmina mais inteira na porção basal, com veias encurvadas a quase $90^{\circ}$, e que vai tornando-se mais dissecada para a porção distal. Esse espécime é considerado como uma grande aflébia que, inicialmente, foi designada Rhacophyllum diversiforme e, provavelmente, relacionada a Rhacopteris hoje, Nothorhacopteris. Trata-se de um espécime de caracteres morfográficos mais semelhantes a àqueles do espécime de Santa Marta. 
Archangelsky (1983, Plate 1 e Plate 2, Fig.4) mostra um fragmento da provável porção basal de uma fronde de Nothorhacopteris argentinica sem contudo identificá-la como aflébia. Todavia, nota-se ai uma raque espessa e uma lâmina com venação dicotômica encurvada a $90^{\circ}$ semelhante em forma, posição e venação à aflébia ora descrita.

O fato de observarem-se, no espécime ora descrito, estriações intervenulares e sua associação intima com pinas de Nothorhacopteris cf. $N$. argentinica na amostra, é fortemente sugestivo de sua afinidade com essa espécie. 


\section{Ordem Cordaitales}

As cordaitales, segundo Taylor 1981, constituem um grupo de gymnospermopsidas do Carbonífero e Permiano que provavelmente evoluíram de membros das progymnospermopsidas.

Os membros dessa ordem foram arborescentes, com algumas árvores de até $40 \mathrm{~m}$ de altura o registro fóssil sugere que as Cordaitales representaram a vegetação típica dominante em algumas áreas durante o Pensilvaniano e o início do Permiano. As árvores possuiam troncos monopodiais com folhas que produziam folhas paralelinérveas acintadas distalmente. Na base do tronco havia raízes escoras, semelhantes às de espécies dos mangues modernos. Os órgãos produtores de grãos de pólen e sementes eram complexos e nascidos sobre ramos distais portando folhas, os grãos de pólens eram monossacados e as sementes foram tipicamente bilaterais com asas conspícuas.

Para McLoughlim \& Drinnan (1996) a Ordem Cordaitales, apresentaria quatro grupos principais diferenciados por critérios morfológicos e anatômicos mas, também, por ocuparem províncias geográficas grandemente separadas no Neopaleozóico. Esses grupos seriam: Cordaitaceae, Vognovskyaceae, Rufloriaceae e o grupo de Noeggerathiopsis e gênero afins envolvendo Noeggerathiopsis, Cheirophyllum, possivelmente Metreophyllum e talvez $\circ$ não-mencionado Eoryphyllum.

Gênero Noeggerathiospis Feistmantel emend. McLoughlin \& Drinnan 1996

\section{Noeggerathiospis sp.}

\section{Sinonímia}

1993-Cordaites sp. cf. C. spatulata (Dana) Rigby, Maheshwari \& Schopt. Millan, An.Acad. bras. 65 (2):213. 
Em curta comunicação, Millan (1993) registrou para a Tafoflora Santa Marta "a presença de folhas de Cordaitales desprovidas de caracteres cuticulares e representadas pela espécie Cordaites sp. cf. C. spatulata (Dana) Rigby, Maheshwari \& Schopt". Essas folhas, segundo sua descrição, apresentavam-se "fragmentadas, com margens inteiras e superfície foliar percorrida por nervuras retilíneas, com raras dicotomias".

Nas coleções estudadas (Mus. Nacional/UFRJ e IGc/USP), nenhum espécime atribuivel a Cordaitales foi localizado e, ao que parace, Millan não chegou a publicar seus espécimes de modo mais completo e com documentação fotográfica.

Embora se tenha em mente a ampla polêmica que há entre a utilização da designação genérica Cordaites Unger ou Noeggerathiopsis Feistmantel para identificação de folhas cordaitaleanas gondvânicas, considera-se aqui a utilização desse último como mais apropriada. Esse posicionamento é fundamentado nas argumentações dos seguintes trabalhos: Bernardes-de-Oliveira \& Pontes (1977) que os diferenciaram com base em dicotomias distribuidas nas folha da base ao ápice em Noeggerathiopsis e apenas na área basal em Cordaites e McLouglin \& Drinnan (1996) que emendando o gênero Noeggerathiopsis, consideraram como caráter distintivo, para praticamente todas as formas gondvânicas, os sulcos estomatíferos profundos intervenulares e marginais de face abaxial de Noeggerathiopsis. Nesse trabalho, McLoughlin \& Drinnan (1996) sugerem que a Família Cordaitaceae cujo gênero foliar é Cordaites seja retida para formas euramericanas.

Portanto, embora não tenha sido possível observar o material de Millan ou coletar algo semelhante, visando evitar confusões futuras na literatura sobre essa tafoflora, prefere-se aqui estabelecer a sinonímia de Cordaites com Noeggerathiopsis.

\section{Semina Incertae Sedis}

As sementes platispérmicas dos gêneros Samaropsis Goeppert e Cordaicarpus Geinitz, conforme Bernardes-de-Oliveira \& Pontes (1976), Bernardesde-Oliveira (1977) e Millan (1995a) podem serem atribuidas às cordaitales, às 
pteridospermales, ou mesmo, às coniferales. Aqui serão tratadas como SEMINAE DISPERSAE-PLATISPÉRMICAS, não the atribuíndo qualquer ordem dentro da Classe Gymnospermopsida, já que apenas impressões foram preservadas.

O gênero Cordaicarpus foi criado por Geinitz (1862) para sementes lenticulares, globulares, ovais ou cordiformes, com uma camada envolvente e preservadas como moldes e impressões. Conforme Bernardes-de-Oliveira (1977), o gênero foi limitado por Seward (1917) a impressões de sementes platispérmicas, com margem relativamente estreita em comparação com Samaropsis.

Goeppert (1864) erigiu o gênero Samaropsis para sementes samaróides, com asa, constituíndo de nucelotescleroteca.

Bernardes-de-Oliveira \& Pontes (1976) verificaram, com base nas diagnoses genéricas de Samaropsis e Cordaicarpus, que o único caráter que realmente distingue ambos os gêneros é a largura do bordo (sarcotesta), já que a esclerotesta nem sempre é visível, deixando margens para dúvidas em casos intermediários.

Bernardes-de-Oliveira \& Pontes (1976) e Bernardes-de-Oliveira (1977), a fim de contornarem estas dificuldades elaboraram um gráfico com base em 25 espécies, relacionadas a esses gêneros, e propuseram que todo espécime apresentando a proporção largura máxima da sarcotesta/ largura máxima do nucelo acima de 1/4.5 inclusive., seja considerado do gênero Samaropsis e abaixo, seja considerado do gênero Cordaicarpus.

Millan (1977) aceitou este método e sugeriu, contudo, que nessa proposição seja escrita: largura máxima do núculo acima de 1/4,5 inclusive, e não somente do nucelo, já que segundo esse autor, em muitas espécies de Samaropsis é muito evidente o nucelo circundado pela esclerotesta.

Millan (1995a) propõe então, face a ocorrência de vários casos "intermediários" entre esses gêneros, um novo enunciado para o Método de Bernardes-de-Oliveira \& Pontes (1976), que seria assim: "todo espécime que apresenta a proporção largura máxima da testa/largura máxima do nucelo acima de $1 / 4,5$, inclusive, pertence ao gênero Samaropsis e abaixo de $1 / 4,5$ pertence ao gênero Cordaicarpus". Com este enunciado, substituiu na proposição original o 
termo "sarcotesta", pelo de maior abrangência ("testa" que incluiria sarcotesta mais esclerotesta) usado sem restrições para ambos os gêneros, quando suas espécies não são típicas. Reconsidera o termo "nucelo", que constava da proposição original, já que excluiria a esclerotesta do corpo central.

\section{Gênero Cordaicarpus Geinitz 1862}

Em 1995a, Millan considerou dentro do Gênero Cordaicarpus alguns espécimes de sementes provenientes da Fazenda Santa Marta que incluiu na espécie C. zeilleri Maithy 1965.

\section{Cordaicarpus zeilleri Maithy 1965}

Material: Col. DGP-MN, ns 1967Pb-A; 1967Pb-B e 1967Pb-C

\section{Descrição e Comparação}

Millan (1995a, Est. I Ffigs. 1-4) descreve esses espécimes como impressões des sementes platispérmicas, de forma levemente elíptica $(1,4: 1)$ a sub-orbicular $(1,2: 1)$ e testa indiferenciada, com sulco mediano, base algo cordada e ápice obtuso.

Essas sementes medem 5 a $6 \mathrm{~mm}$ de comprimento por $3,5 \mathrm{~mm}$ a $5 \mathrm{~mm}$ de largura máxima, na porção mediana. O nucelo tem uma largura máxima de $2,5 \mathrm{~mm}$ de largura constante de $0,5 \mathrm{~mm}$, o que resulta numa proporção de 1:5 entre largura máxima do nucelo/largura da testa. Configure-se assim com esta sua designação genérica Cordaicarpus. Quanto à sua designação específica verifica-se as mesmas características diagnósticas descritas por Maithy (1965) ao definir a espécie Cordaicarpus zeilleri. Como já ressaltaram Bernardes-de-Oliveira \& Pontes (1976), Bernardes-de-Oliveira (1977) bem como, Millam (1995), essa espécie apresentando nas formas indianas (Maithy 1965, Est.1, figs. 1-3 e fig-texto 1 e 2) como nas formas brasileiras, uma crista mediana sulco correspondendo ao tubo micropilar na região apical e basal do nucelo com uma fraca linha mediana unindo as duas regiões.

Infelizmente, não foi possivel localizar esses espécimes na Coleção Científica do Museu Nacional para rever essas descrições e documentá-los. 


\section{Gênero Samaropsis Goeppert 1864}

Ainda em 1995a, Millan incluiu no Gênero Samaropsis Goeppert alguns espécimes aos quais identificou como uma nova espécie Samaropsis itapevensis Millan, 1995a.

\section{Samaropsis itapevensis Millan 1995a}

Material: Col. DGP-MN, ns 1965Pb (holótipo) e 1969Pb (parátipo)

\section{Diagnose}

Conforme Millan (1995a) essa forma é, diagnosticamente, caracterizada como possuindo as seguintes características:"Semente platsipérmica de forma elíptica na posição vertical, ápice agudo a obtuso e base algo cordada, sem formação de sinus e sem saliência superficial. Testa indiferenciada, estreita nas regiões médio-proximal e mais larga na região apical, envolvendo o nucelo, que é elíptico, com base redonda e ápice agudo a obtuso e superfície coberta de estrias, cuja orientação predominante é divergente no ápice. O nucelo é atravessado em toda sua extensão por um sulco mediano".

\section{Descrição e Comparação}

Essas sementes (1965Pb, 1969Pb) medindo 5,5 e 6,5mm de comprimento por 4 e $4,5 \mathrm{~mm}$ de largura máxima, na porção mediana, respectivamente, apresentam nucelo de largura máxima de 2,5 e 3,0 $\mathrm{mm}$. Suas testas apresentam largura máxima de 1,0mm e 1,5mm, o que resulta numa proporção de 1:2,5 e 1:2, o que as coloca dentro do gênero Samaropsis Goeppert, conforme critério de Bernardes-de-Oliveira \& Pontes (1976) ainda que desde o seu caráter diminuto se assemelhasse a Cordaicarpus.

Quanto à sua designação especifica, resulta de sua identificação dentro do Grupo I do Esquema Maithy/Millan, isto é, composto por sementes elípticas/ovais, na posição vertical, com testa estreita/larga, sem sinus e sem saliência, constituindo 
pelas espécies Nummulospermum bowenense Walkom da Austrália e $S$. dolianitii Millan de Cerquilho (SP) das quais é perfeitamente distinta.

Infelizmente, também não foi possivel localizar esses espécimes na Coleção Científica do Museu Nacional para rever essas descrições e documentá-los.

Essa forma que ocorre no andar Karharbari da Índia (Permiano inferiorSakmariano) e na Formação Rio Bonito (Permiano inferior-Artinskiano) é aqui registrada desde o Carbonífero superior (Westfaliano) na Tafoflora Santa Marta. 
CAPÍTULO VI 


\section{CAPÍTULO VI. RESULTADOS PALINOLÓGICOS}

\section{VI.1. Palinoestratigrafia do Subgrupo Itararé}

O Subgrupo Itararé já foi objeto de estudo de vários autores que tentaram, a partir de dados pontuais de alguns afloramentos ou do conjunto destes, posicionar bioestratigraficamente, suas diversas assembléias fossiliferas.

Segundo Souza (2000, inédito), os zoneamentos palinológicos mais importantes envolvendo os niveis do Subgrupo Itararé no Estado de São Paulo foram aqueles realizados por Daemon \& Quadros (1970), Saad (1977), Arai (1980), Sundaram $(1980,1987)$. Contribuições a partir de afloramentos foram mais frequentes a partir das duas últimas décadas, destacando-se os trabalhos de Lima et al. (1983), Souza et al. $(1990,1993 a$, b e c , 1996, 1997, 1999, 2000), Souza \& Petri (1998), Souza $(1996,1997,1998)$.

Mais recentemente, Souza (2000, inédito) propõe um novo zoneamento palinobioestratigráfico para o Subgrupo Itararé, na porção nordeste da bacia do Paraná, abrangendo o Estado de São Paulo e norte do Estado do Paraná (vide Quadro VI. 1).

A situação e a correlação das propostas palinobioestratigráficas para o Paleozóico superior da bacia do Paraná encontram-se resumidos no Quadro VI.2. 


\begin{tabular}{|c|c|c|c|c|c|c|}
\hline \multicolumn{2}{|c|}{$\begin{array}{c}\text { Subgrupo } \\
\text { Itararé }\end{array}$} & \multicolumn{3}{|c|}{$\begin{array}{l}\text { Formação } \\
\text { Rio Bonito } \\
\end{array}$} & \multirow{2}{*}{$\begin{array}{l}\text { Litoestratigrafia } \\
\text { Bioestratigrafia }\end{array}$} & \multirow{2}{*}{$\begin{array}{l}+1 \\
\text { Qิ. } \\
\text { ò } \\
\text { c) }\end{array}$} \\
\hline $\begin{array}{c}\text { Zona } \\
\text { Ahrensisporites } \\
\text { cristatus }\end{array}$ & $\begin{array}{c}\text { Zona } \\
\text { Potonieisporites } \\
\text { neglectus }\end{array}$ & \begin{tabular}{|c|} 
Subzona \\
Protohaploxypinus \\
goraiensis \\
\end{tabular} & $\begin{array}{l}\text { Zona Vittatina } \\
\begin{array}{c}\text { Subzona } \\
\text { Caheniasaccites } \\
\text { Flavatus }\end{array} \\
\end{array}$ & $\begin{array}{c}\text { Subzona } \\
\text { Hamiapollentites } \\
\text { karroensis }\end{array}$ & & \\
\hline & & & & & Calamospora hartungiana & \\
\hline & & & & & Calamospora liquida & \\
\hline & & & & & Punctatisporites gretensis & \\
\hline & & & & & \begin{tabular}{|l} 
Punctatispontes tuclaulus \\
Retusotriletes nigritellus \\
\end{tabular} & \\
\hline & & & & & Granulatisporites triconvexus & \\
\hline & & & & & \begin{tabular}{|l|} 
Granulatisporites varigranifer \\
Granulatisporites austroamerica \\
\end{tabular} & \\
\hline & & & & & \begin{tabular}{|l|} 
Granulatisporites confluens \\
Crclogranisporites firmus \\
\end{tabular} & \\
\hline & & & & & Verrucosisporites microtuberosu & \\
\hline & & & & & \begin{tabular}{|l|} 
Verrucosisporites morulatus \\
Apiculiretusispora variornatata \\
\end{tabular} & \\
\hline & & & & & $\begin{array}{l}\text { Apiculatisporis sp. } \\
\end{array}$ & \\
\hline & & & & & \begin{tabular}{|l} 
Anapiculatisporites argentinensis \\
Dibolisporites disfacies
\end{tabular} & \\
\hline & & & & & Horriditriletes uruguaiensis & \\
\hline & & & & & Raistrickia pinguis & \\
\hline & & & & & \begin{tabular}{|l|} 
Raistrickia paganclana \\
Raistrickia rotunda \\
\end{tabular} & \\
\hline & & & & & $\begin{array}{l}\text { Convulatispora sp. } \\
\end{array}$ & \\
\hline & & & & & \begin{tabular}{|l|} 
Convolutispora muriornata \\
Reticulatisporites pseudopalliatu
\end{tabular} & \\
\hline & & & & & Reticulatisporites passaspectus & \\
\hline & & & & & \begin{tabular}{|l|} 
Dictyotriletes muricatus \\
\end{tabular} & \\
\hline & & & & & \begin{tabular}{|l} 
Foveosporites hortonensis \\
Ahrensisporites cristatus \\
\end{tabular} & \\
\hline & & & & & Stenozonotriletes clarus & \\
\hline & & & & & \begin{tabular}{|l} 
Lundbladispora braziliensis \\
Lundbladispora riobonitensis
\end{tabular} & \\
\hline & & & & & Densosporites triangulatus & \\
\hline & & & & & \begin{tabular}{|l|} 
Densosporites annulatus \\
Densosporites stellatus
\end{tabular} & \\
\hline & & & & & Kraeuselisporites volkheimenii & \\
\hline & & & & & \begin{tabular}{|l} 
Vallatisporites vallatus \\
\end{tabular} & \\
\hline & & & & & $\begin{array}{l}\text { Vallatisporites arcuatus } \\
\text { Vallatisporites ciliaris }\end{array}$ & \\
\hline & & & & & Vallatisporites punctatus & \\
\hline & & & & & \begin{tabular}{|l|} 
Vallatisporites spinosus \\
Cristatisporites indianabundus \\
\end{tabular} & \\
\hline & & & & & $\begin{array}{l}\text { Cristatisporimes mongnexus } \\
\text { Cristatisporites connexus }\end{array}$ & \\
\hline & & & & & \begin{tabular}{|l|} 
Cristatisporites inconstans \\
rictatsisponites menendeziii
\end{tabular} & \\
\hline & & & & & \begin{tabular}{|l|} 
Cristatspontes menenaezl \\
Cristatisporites spinosus \\
\end{tabular} & \\
\hline & & & & & Cristatisporites morungavensis & \\
\hline & & & & & \begin{tabular}{|l|} 
Bascaudaspora canipa \\
Cirratriradites veeversii \\
\end{tabular} & \\
\hline & & & & & Spelaeotriletes ybertii & \\
\hline & & & & & \begin{tabular}{|l|} 
Velamisporites $s p$. \\
Psomospora detecta
\end{tabular} & \\
\hline & & & & & \begin{tabular}{|l|} 
Psomospora detecta \\
Florinities sp. \\
\end{tabular} & \\
\hline & & & & & Cannanoropollis janakii & \\
\hline & & & & & \begin{tabular}{|l} 
Cannanoropollis triangularis \\
Cannanoropollis densus \\
\end{tabular} & \\
\hline & & & & & Cannanoropollis perfectus & \\
\hline & & & & & $\begin{array}{l}\text { Plicatipollenites malabarensis } \\
\text { Plicatipollenites gondwanensis }\end{array}$ & \\
\hline & & & & & $\begin{array}{l}\text { Plicatipollenites trigonalis } \\
\end{array}$ & \\
\hline & & & & & \begin{tabular}{|l} 
Plicatipollenties densus \\
Crucisaccites /atisulcatus
\end{tabular} & \\
\hline & & & & & $\begin{array}{l}\text { Cruclsaccires latiluiliatus } \\
\text { Crucisaccites monoletus }\end{array}$ & \\
\hline & & & & & Potonieisporites novicus & \\
\hline & & & & & \begin{tabular}{|l} 
Potonieisporites neglectus \\
Potonieisporites triangulatus
\end{tabular} & \\
\hline & & & & & Potonieisporites barrelis & \\
\hline & & & & & Potonieisporites densus & \\
\hline & & & & & \begin{tabular}{|l} 
Potonespontes congoentsispos brasiliensis \\
Potonieisportes
\end{tabular} & \\
\hline & & & & & Potonieisporites magnus & \\
\hline & & & & & Divarisaccus stringoplicatus & \\
\hline & & & & & Caheniasaccites sp. & \\
\hline & & & & & ? Striomonosaccites sp. & \\
\hline & & & & & $\begin{array}{l}\text { Scheuringipollenites maximus } \\
\text { Limitisporites rectus }\end{array}$ & \\
\hline & & & & & Limitisporites sp. & \\
\hline & & & & & Protohaploxypinus amplus & \\
\hline & & & & & $\frac{\text { Protohapoxyplinus ilmplaus }}{\text { Protohoploxypinus goraiensis }}$ & \\
\hline & & & & & \begin{tabular}{|l|} 
Protohaploxypinus micros \\
\end{tabular} & \\
\hline & & & & & \begin{tabular}{|l} 
Protohaploxypinus panaki \\
Striatoabieites $s p$. \\
\end{tabular} & \\
\hline & & & & & Complexisporites polymorphus & \\
\hline & & & & & $\begin{array}{l}\text { Hamiapollenites tractiferinus } \\
\text { Hamiaoollenites fusiformis }\end{array}$ & \\
\hline & & & & & \begin{tabular}{|l} 
Hamlapolilenires usifrormis \\
Vittatina wodehousei
\end{tabular} & \\
\hline & & & & & \begin{tabular}{|l} 
Vittatina vittifera \\
\end{tabular} & \\
\hline & & & & & \begin{tabular}{|l} 
Vittifera subsaccata \\
Vitatatina saccata
\end{tabular} & \\
\hline & & & & & \begin{tabular}{|l|l} 
Vittatina costabilis \\
\end{tabular} & \\
\hline & & & & & Costapollenites ellipticus & \\
\hline & & & & & Basmanties S. & \\
\hline & & & & & Deusilites tenuistriatus & \\
\hline & & & & & Murospora sp. & \\
\hline & & & & & \begin{tabular}{|l} 
Reticulatilisportes sp. \\
Ahrensisporites sp.
\end{tabular} & \\
\hline
\end{tabular}



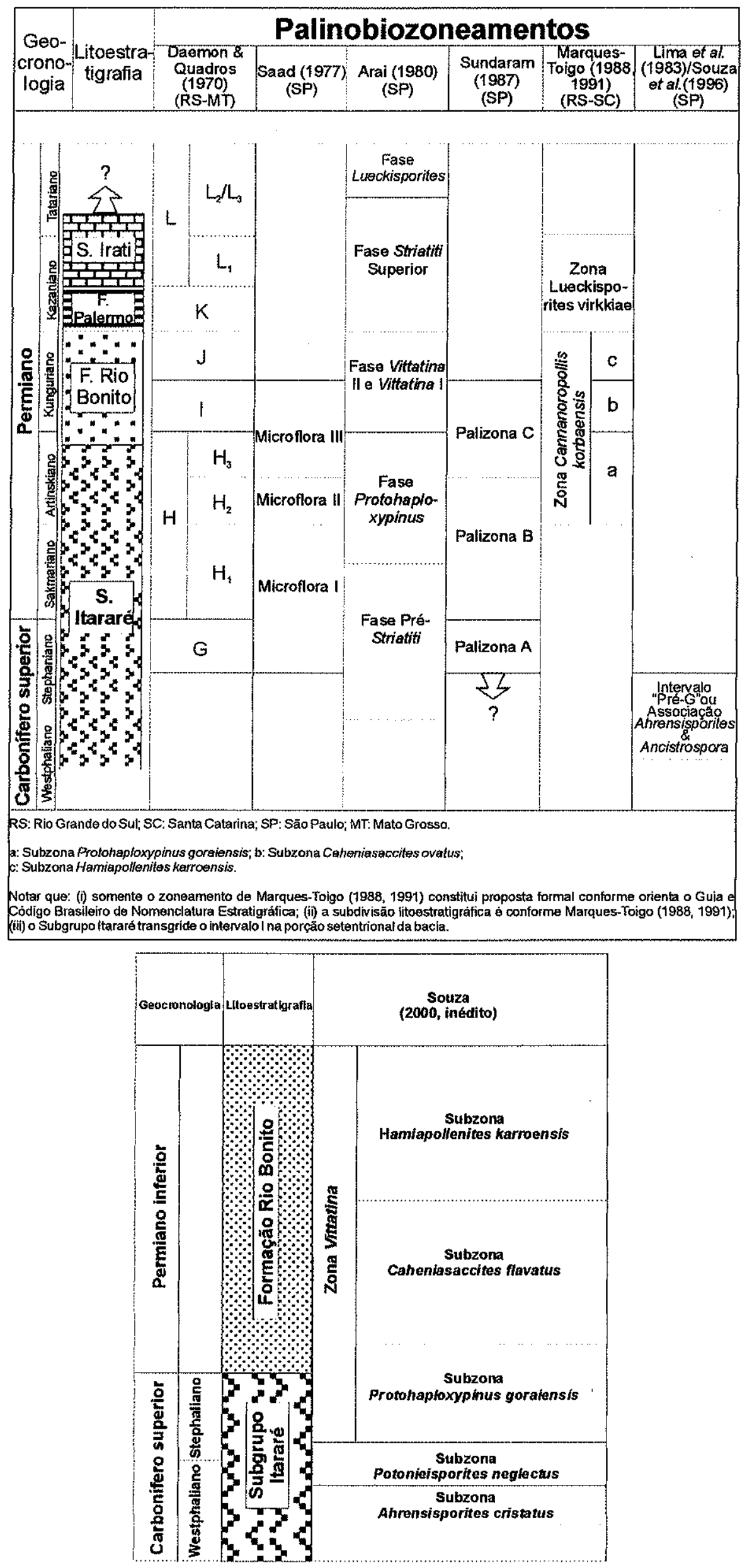

Quadro VI.2 - Situação e correlação das propostas palinobioestratigráficas para o Paleozóico superior da Bacia do Paraná, modificado de Souza (2000, inédito). 
Souza (2000, inédito) reconheceu a presença de três zonas biointervalos: Zona Ahrensisporites cristatus, Zona Potonieisporites neglectus e Subzona Protohaploxypinus goraiensis, base da Zona Vittatina (sensu Marques-Toigo, 1988, 1991) Vide Quadro VI.1. Essas unidades bioestratigráficas têm as seguintes características:

Zonas Biointervalo Ahrensisporites cristatus: refere-se à porção inferior do Subgrupo Itararé e tem como característica "o predomínio de grãos de pólen monossacados de simetria radial e bilateral e/ou de esporos, principalmente os cingulizonados e lisos". Os tipos palinomórficos presentes nessa zona indicam o predomínio de Lycopsidas, Filicopsidas e Gymnospermopsidas.

O limite inferior dessa zona é delimitado pela "presença, ou aparecimento das seguintes espécies de esporos: Granulatisporites varigranifer, Apiculiretusisporia variornata, Anapiculatisporites argentinensis, Raistrikia pinguis, $R$. rotunda, $R$. paganciana, Convolutispora ordeñenzii, C. muriornata, Foveosporites hortonensis, Ahrensisporites cristatus, Cristatisporites menendezii, C. spinosus, C. inordinatus, Bascaudaspora canipa e Psomospora detecta e pela presença ou aparecimento, de um número significativo de espécies de grãos de pólen monossacados, principalmente: Cannanoropolis (C. janakii, C.triangularis, C. densus), Plicatipollenites ( $P$. malabarensis, $P$. gondwanensis, $P$. triangonalis, $P$. densus), Potonieisporites ( $P$. nivicus, $P$. neglectus, $P$. triangulatus, $P$. barrelis, $P$. densus, $P$. congoensis, $P$. brasiliensis, P.magnus), Divarisaccus stringoplicatus, Cahenisaccites (C. flavatus, C. sp.). A partir da base da Zona, podem também ocorrer grãos de pólen bissacados: Limitisporites ( $L$. rectus, $L$. sp.) e teniados Protohaploxypinus amplus. Quando presentes, ocorrem em quantidades subsidiárias".

O limite superior dessa zona é " delimitado pelo desaparecimento das seguintes espécies: Granulatisporites varigranifer, Anapiculatisporites argentinensis, Raistrikia pinguis, Foveosporites hortonensis, Ahrensisporites cristatus, Cristatisporites menendezii, C. spinosus, C. inordinatus e Psomospora e pelo aparecimento de Crucisaccites monoletus e Scheuringipollenites maximus, que delimitam a base da Zona Biointervalo subsequente". . 
Espécies exclusivas: Granulatisporites varigranifer, Anapiculatisporites argentinensis, Raistrikia pinguis, Foveosporites hortonensis, Ahrensisporites cristatus, Cristatisporites menendezii, C. spinosus, C. inordinatus, C. indignabundus, Cirratriradites veeversii e Psomopora detecta.

Zona Biointervalo Potonieisporites neglectus: refere-se à porção média do Subgrupo Itararé. Assim como na zona anterior, essa zona é também caracterizada por elementos relacionados a Lycopsidas, Filicopsidas e Gymnospermopsidas.

O limite inferior da zona é delimitado pelo desaparecimento das espécies exclusivas da zona anteriormente descrita e pelo surgimento de Crucisaccites monoletus e Scheuringipollenites maximus.

O limite superior é delimitado "pelo desaparecimento das seguintes espécies: Calamospora hartungiana, Punctatisporites lucidulus, Cyclogranisporites firmus, Apiculiretusispora variornata, Apiculatisporites sp., Dibolisporites disfacies, Raistrikia pinguis, Convolutispora ordoñenzii, C. muriornata, Reticulatisporites passaspectus, Stenozonotriletes clarus, Krauselisporites volkheimerii, Velamisporites sp., Florinites sp., Crusisaccites monoletus, Potonieisporites neglectus, P. triangulatus, $P$. barrelis, Divarisaccus stringoplicatus, e pelo aparecimentos das seguintes espécies: Protohaploxypinus goraiensis, P. micros, P. panaki, P. limpidus, Complexisporites polymorphus, Hamiapollenites tractiferinus, $H$. fusiformis, Vittatina wodehousei, $V$. vittifera, V. subsaccata, V. saccata, V. constabilis e Costapollenites ellipticus".

Espécie exclusiva: Crucisaccites monoletus

Subzona Protohaploxypinus goraiensis: refere-se à porção superior do Subgrupo Itararé. Nesse intervalo estratigráfico ocorre decréscimo acentuado de grãos de pólen monossacados e de esporos, e grande aumento dos grãos de pólen teniados e poliplicados.

O limite inferior é marcado pelo desaparecimento das espécies: Cyclogranisporites firmus, Apiculiretusispora variornata, Apiculatisporis sp., Dibolisporites disfacies, Raistrickia rotunda, Convolutispora ordoñenzii, $C$. muriornata, Reticulatisporites passaspectus, Dictyotriletes muricatus, Stenozonotriletes clarus, Krauselisporites volkheimerii, Velamisporites sp., Florenites 
sp., Crucisaccites monoletus, Potonieisporites neglectus, P. triangulatus, $P$. barrelis e Divarisaccus stringoplicatus.

"O limite superior desta Subzona com a Subzona Caheniasaccites ovatus (= C.flavatus), corresponde a base da Formação Rio Bonito, nos estados do Rio Grande do Sul e Santa Catarina, não foi verificado no material estudado e é marcado pelo nivel de extinção de Protohaploxypinus goraiensis".

\section{VI.2. Generalidades}

As palinofloras das camadas hulheíferas de Itapeva estão sendo, pela primeira vez, estudada detalhadamente. Resultados preliminares já foram divulgados por Bernardes-de-Oliveira et al. (1999) e Zampirolli et al. (2000).

Os palinomorfos aqui tratados incluem esporomorfos (esporos e grãos de pólen do Reino Plantae/Divisão Trachaeophyta) e elementos do fitoplâncton (algas do Reino Protista da Divisão Prasinophyta).

Como já foi mencionado anteriormente, o material palinológico estudado é proveniente de amostras de superfície e foi observado e quantificado nas três lâminas de números $286 \mathrm{~A}, \mathrm{~B}$ e C , depositadas na Palinoteca do Instituto Geológico da Secretaria do Meio Ambiente do Estado de são Paulo (IG/SMA), sob codificação IG-P: $286 \mathrm{~A}$ a $\mathrm{C}$.

São apresentados 19 táxons específicos de palinomorfos. Procedem de amostra recolhida/ coletada no afloramento estudado. Vide Fig. III.2. Desses 19 táxons específicos, onze espécies correspondem a esporos agrupados em dez gêneros, sete espécies referem-se a grãos de pólen agrupados em quatro gêneros distintos e uma espécie de fitoplâncton.

A classificação dos esporomorfos foi dividida em Proxigerminantes (esporos) e Variegerminantes (grãos de pólen), utilizando o sistema proposto por Potonié (1970), além das subdivisões de categorias taxonômicas inferiores reunidas a partir do esquema de Potonié (1970). Para os elementos prasinofíticos do fitoplâncton segue-se a classificação de Guy-Ohlson (1996). 
A seguir, é apresentada uma lista sistemática dos táxons registrados, cujos melhores espécimes têm sua localização em lâmina (England Finder), codificação da coleção e documentação fotográfica ai indicadas.

\section{V.3. Listagem Sistemática}

Anteturma Proximegerminantes Potonié 1970

Turma Triletes (Reinsch) Dettman 1963

Supraturma Acavatitriletes (Lüber) Dettman 1963

Subturma Azonoletes (Lüber) Dettman 1963

Infraturma Laevigati (Bennié \& Kidston) Potonié 1956

Gênero Punctatisporites (Ibrahim) Potonié \& Kremp 1954

Punctatisporites gretensis Balme \& Hennelly 1956 (Est.11, Fig.1)

Punctatisporites lucidulus Playford \& Helby 1968 (Est.11,Fig.2)

Infraturma Apiculati (Bennié \& Kidston) Potonié 1956

Subinfraturma Granulati (Dybová \& Jachowicz 1957)

Granulatisporites austroamericanus Archangelsky \& Gamerro 1979 (Est.11, Fig.3)

Subinfraturma Verrucati Dybová \& Jachowicz 1957

Gênero Verrucosisporites (tbrahim) Smith 1971

Verrucosisporites morulatus (Knox) Smith \& Butterworth 1967 (Est.11, Fig.4)

Subinfraturma Nodati (Dybová \& Jachowicz 1957)

Gênero Dibolisporites (Richardson) Playford 1976

Dibolisporites disfacies Jones \& Truswell 1992 (Est11, Fig.5)

Subinfraturma Baculati Dybová \& Jachowicz 1957

Gênero Raistrickia (Schopf, Wilson \& Bentall) Potonié \& Kremp 1954

Raistrickia pinguis Playford 1971 (Est.11, Fig.6)

Subturma Zonotriletes Waltz 1935

Infraturma Auriculati (Schopf) Dettman 1963

Gênero Ahrensisporites Potonié \& Kremp 1954

Ahrensisporites sp. (Est.11, Fig.7)

Infraturma Cingulati (Potonié \& Klaus) Dettman 1963

Gênero Reticulatisporites (Ibrahim) Neves 1964

Reticulatisporites sp. (Est.11, Fig.8)

Subinfraturma Murornati Potonié \& Kremp 1954

Gênero Murospora Sommers 1952

Murospora sp. (Est.11, Fig.9) 
Suprasubturma Laminatitriletes Smith \& Butterworth 1967

Subturma Zonolaminatitriletes Smith \& Butterworth 1967

Infraturma Cingulicavati Smith \& Butterworth 1967

Gênero Lundbladispora (Balme) Playford 1965

Lundbladispora riobonitenses Marques-Toigo \& Picarelli 1984 (não ilustrado)

Gênero Vallatisporites Hacquebard 1957

Vallatisporites ciliaris (Lüber) Sullivan 1964 (Est.11, Fig.10)

Anteturma Variegerminantes Potonie 1970

Turma Saccites Erdtmann 1947

Subturma Monosaccites (Chitaley) Potonié \& Kremp 1954

Infraturma Triletesacciti Leschik 1955

Gênero Plicatipollenites Lele 1964

Plicatipollenites malabarensis (Potonié \& Sah) Foster 1975 (Est.12, Fig.1)

Plicatipollenites densus Srivastava 1970 (Est.11, Fig.11)

Infraturma Vesiculomonoraditi Pant 1954

Gênero Potonieisporites Bharadwaj emend. Bharadwaj 1964

Potonieisporites brasiliensis (Nahuys, Alpern \& Ybert) Archangelsky \& Gamerro 1979 (Est.12, Fig.2)

Potonieisporites congoensis Bose \& Maheshwari 1968 (Est.12, Fig.4)

Potonieisporites magnus Lele \& Karin 1971 (Est.12, Fig.3)

Gênero Divarisaccus Venkatachala \& Kar 1966

Divarisaccus stringoplicatus Ottone 1991 (não ilustrado)

Gênero Caheniasaccites (Bose \& Kar, 1966) Azcuy \& Di Pasquo 2000

Caheniasaccites flavatus (Bose \& Kar, 1966) Azcuy \& Di Pasquo 2000 (Est.12, Fig.5)

Subturma Disaccites Cookson 1947

Infraturma Disaccitrileti (Leschik) Potonie 1958

Divisão Prasinophyta Round 1971

Ordem Pterospermatales

Familia Tasmanitaceae (Sommer) Sommer \& Van Boekel 1963

Gênero Tasmanites Newton 1875

Tasmanites sp. (Est.12, Fig.6) 
Dentre os táxons registrados, dois foram noticiados pela primeira vez na bacia do Paraná recentemente por Souza (2000, inédito): Granulatisporites austroamericanus Archangelsky \& Gamerro 1979 e Dibolisporites disfacies Jones \& Truswell 1992.

Foi realizada uma contagem de morfogrupos para análise quantitativa. Foram contados cerca de 200 espécimes por lâmina. Para a contagem foram agrupados em: esporos lisos, esporos cingulizonados, grãos de pólen monossacados de simetria radial, grãos de pólen de simetria bilateral, grãos de pólen bissacados e prasinófitas. A partir da contagem dos morfogrupos foi possível elaborar o seguinte gráfico. Fig. VI.1. 


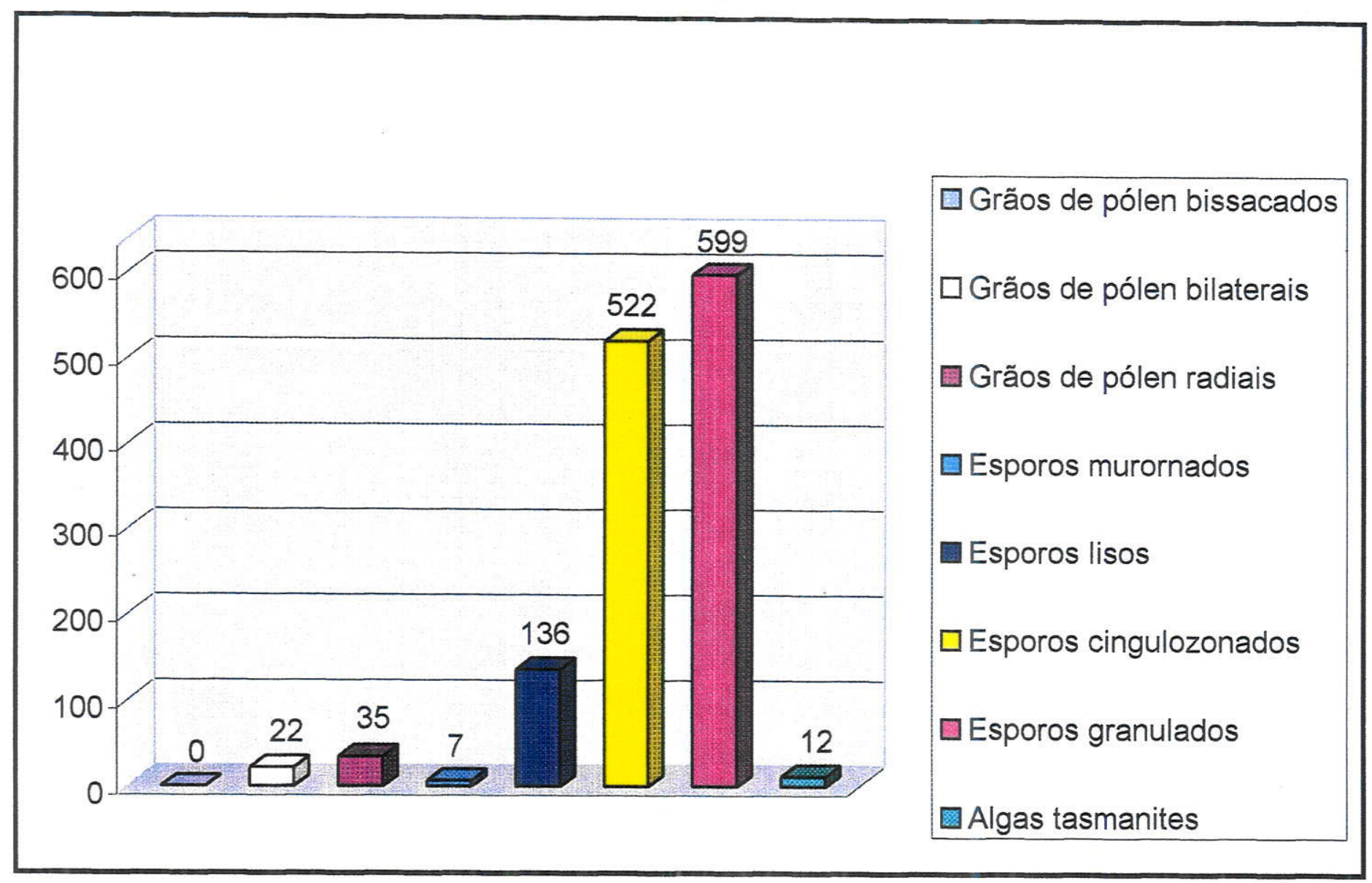

Fig. VI.1: Quantificação dos morfogrupos das Lâminas IG-P 286 A, B, C da fazenda Santa Marta, Itapeva (SP). 
As afinidades botânicas dos esporomorfos são apresentadas no quadro VI.3., de acordo com Souza (2000, inédito) adaptando-se à palinoflora de Santa Marta.

\begin{tabular}{|l|c|c|l|}
\hline & \multicolumn{2}{|c|}{ Classe/Ordens } & Gêneros \\
\hline \multirow{3}{*}{$\begin{array}{l}\text { Divisão } \\
\text { Tracheaophyta }\end{array}$} & Lycopsida & & Lundbladispora, Vallatisporites, Cristatisporites \\
\cline { 2 - 4 } & Filicopsida & & $\begin{array}{l}\text { Punctatisporites, Granulatisporites, Verrucosisporites, } \\
\text { Raistrickia }\end{array}$ \\
\cline { 2 - 4 } & Gymospermopsida & Pteridospermales & Limitisporites \\
\hline & & Coniferales & $\begin{array}{l}\text { Plicatipollenites, Potonieisporites, } \\
\text { Caheniasaccites }\end{array}$ \\
\hline
\end{tabular}

Fig.VI.3. Afinidades botânicas da assembléia palinológica da Tafoflora Santa Marta.

Embora não tenha sido encontrado em nível específico alguns espécimes de palinomorfos, foram reconhecidos dois gêneros: Limitisporites e Cristatisporites, além das espécies listadas.

Nota-se, a ausência de esfenópsidas no registro de microfósseis, embora sua presença na vegetação local seja denunciada por macrofósseis de Koretrophyllites, Sphenophyllum, Paracalamites. Quanto às licópsidas, predominantes na assembléia palinológica, não se fazem presentes macroscopicamente. Essas discrepâncias talvez possam ser atribuídas a diferenças de habitats e ambientes de deposição, conforme será discutido no capítulo VII.

Outras discrepâncias semelhantes entre os demais táxons também serão discutidas no capítulo seguinte. 
CAPÍTULO VII 


\section{CAPITULO VII. TRATAMENTO/INTERPRETAÇÕES DE DADOS}

Os dados macro e microflorísticos, obtidos nas análises de campo e de laboratório do material da tafoflora Santa Marta, são agora observados buscando inferências quanto aos aspectos de ambiente tafonômico, paleoecológico, paleofitogeográfico e paleoclimático, bio e cronoestratigráficos.

\section{VII.A. Dados Macroflorísticos}

\section{VII.A1. Aspectos do Ambiente Tafonômico}

A assembléia fitofossilifera da fazenda Santa Marta, como já mencionado no Capitulo III, caracteriza-se por apresentar impressões de folhas, caules e sementes, abundantemente acumulados, em meio a pequena quantidade de material detrítico siltico-argiloso. As impressões, que se acumulam uma sobre as outras, são sugestivas de uma vegetação relativamente densa, depositada "in situ" ou com pequeno transporte.

O grande acúmulo desses fragmentos de vegetais dando origem a camadas de carvão pode indicar, ainda, um ambiente aquoso, redutor, onde se acumulavam formas higrófilas, higro-mesófilas e prováveis mesófilas corroborando a idéia de autoctonia associada a curta aloctonia.

O ambiente deposicional sugerido por Cabral Jr. \& Motta (1985) para a unidade faciológica B é o de planície deltaica. Essa Interpretação baseou-se na litologia (arenitos finos a médios, com granodecrescência ascendente passando a siltitos e camadas de carvão no topo); nas estratificações cruzadas de grande porte, mais comuns nos arenitos basais passando a microcruzadas nas litologias finas superiores, e na presença de bioturbação por raízes, nas fácies peliticas.

Essas são representadas por siltito cinza claro a escuro interlaminados com niveis argilosos, onde foram preservados os fitofósseis. Subordinadamente, ocorrem camadas de siltitos carbonosos e carvão.

Segundo Cabral Jr. \& Motta (1985), as análises paleontológicas, corroboram essa interpretação, visto que a matéria orgânica detectada em siltitos associados ao nível de carvão é constituída, na sua quase totalidade, por material lenhoso, 
evidenciando, provavelmente, um ambiente continental calmo, de águas doces, no qual o acúmulo de matéria orgânica se deu em pequenas bacias carbonosas, rasas, relacionadas, possivelmente, a baixios interdistributários.

Os fitofósseis não se dispõem perfeitamente horizontalizados sobre as camadas síltico-argilosas, mais acomodam-se segundo os leitos das microestratificações cruzadas. Nenhuma orientação preferencial foi notada.

$O$ alto grau de intemperismo da matriz não permitiu a retirada de grandes blocos onde fragmentos mais completos pudessem ser observados. Entretanto, formas delicadas e relativamente grandes de Botrychiopsis e aflébia de Nothorhacopteris puderam ser observadas na coleção estudada. Por outro lado, é notável o fato de que em alguns niveis das amostras ocorrem quase que, exclusivamente, caules de esfenófitas desprovidos de folhas (Paracalamites), o que sugere, nesses casos, ligeira oriertação preferencial. Tal fato poderia ser interpretado como pequenas oscilações sazonais no fluxo de água.

Ainda que o ambiente de acúmulo desses vegetais tenha sido provavelmente redutor, como aventaram Cabral Jr. \& Motta (1985), o intenso intemperismo atual (área fortemente enxarcada), favoreceu a lixiviação da matéria orgânica preservada, e a descoloração dos espécimes, o que resultou em impressões de cor pouco contrastada em relação à matriz.

\section{VII.A2. Interpretações Paleoecológicas}

Além das interpretações tafonômicas, os dados obtidos na análise sistemática da macroflora permitem algumas inferências do ponto de vista paleoecológico, paleoclimático, bioestratigráfico e cronológico.

Antes de se considerar os aspectos paleoecológicos da assembléia fitofossilifera alguns termos conceituais devem ser registrados. Segundo FontQuer (1985) tem-se:

Planłas hidrófilas- são plantas aquáticas que vivem parcial ou totalmente submersas, podendo apresentar heterofilia.

Plantas higrófilas- são plantas que vivem em solos úmidos a muito úmidos. 
Plantas mesófilas- são plantas que se desenvolvem sob condições de temperatura e, sobretudo, de umidade medianas, isto é, não muito altas nem muito baixas. Geralmente vivem em terras firmes não muito elevadas elou em áreas entre rios.

Plantas xerófilas. são plantas que vivem em solos secos seja por causas climáticas ou edáficas.

Conforme Remy \& Remy (1977, in Cúneo, 1986) são exemplos de comunidades carboniferas hidro-higrófilas: as licófitas herbáceas de mangues ou de águas salobras. Plantas micro e mesofanerofíticas do tipo primofilices, esfenófitas, fetos arborescentes e algumas cordaitales arborescentes, também fazem parte dessas comunidades.

São exemplos de comunidades carboniferas higro-mesófilas a mesófilaspossiveis pteridospermas ou progimnospermas arborescentes ou arbustivas (Nothorhacopteris, Botrychiopsis, Eusphenopteris) com exigências edáficas higromesófilas (conforme Archangelsky \& Cúneo, 1981; Archangelsky, 1983 e Cúneo, 1986). Há que se ressaltar aqui que, segundo Cúneo (1986), as Nothorhacopteris ocorrem em comunidades puras ou em misturas de proporções muito pequenas com elementos fisionomicamente similares tais como Botrychiopsis, Eusphenopteris e Fedekurtzia.

São exemplos de comunidades carboníferas mesófilas a meso-xerófilasaquelas que apresentam abundância de gimnospermas, na forma de bosques concentrados ou abertos de Cordaitales, Ginkgoales, Vojnowskiales, Pleridospermas, em áreas pró-glaciais, havendo Coníferas e Cordaitales de altitude.

Em sintese, essas comunidades, segundo seu ambiente de vida, podem ser verificadas no quadro VII.1. abaixo: 


\begin{tabular}{|c|c|}
\hline Tipo Ambiente & Composisao \\
\hline higro higróflas & 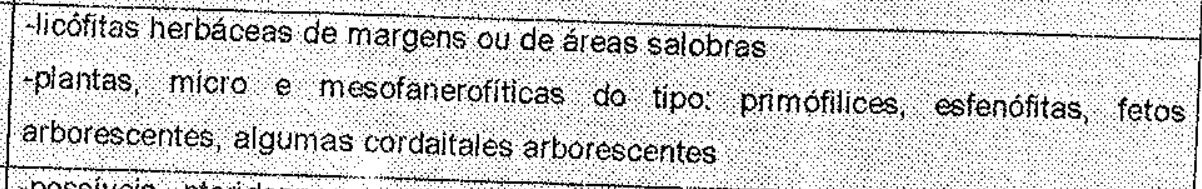 \\
\hline higroumesofilas & 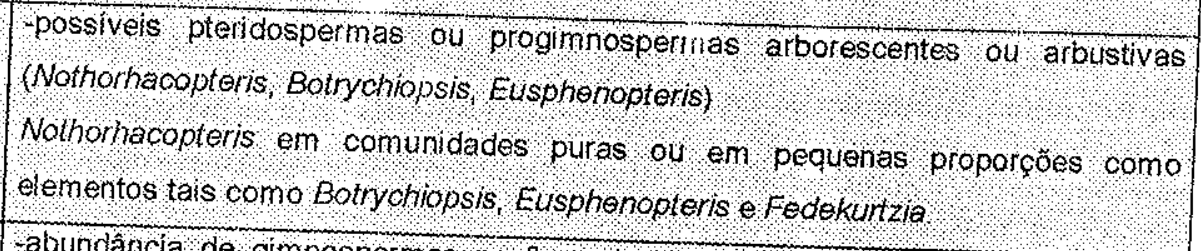 \\
\hline $\begin{array}{l}\text { mesófilas a neso } \\
\text { xerófilas }\end{array}$ & 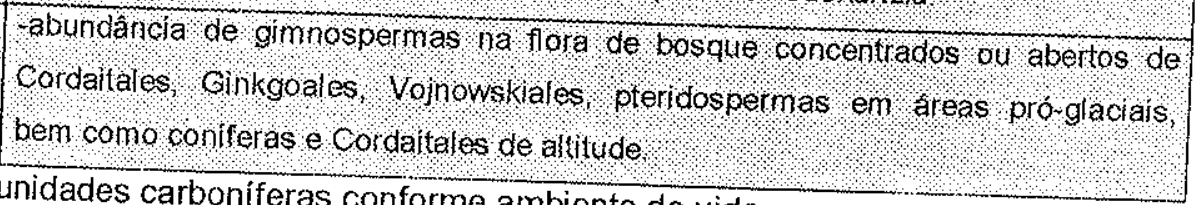 \\
\hline
\end{tabular}

Considerando a assembléia macrofitofossilífera Santa Marta do ponto de vista paleoecológico, podem ser extraidas as seguintes inferências:

As esfenófitas estão representadas por duas ordens: Sphenophyllales e Equisetales.

O gênero Sphenophyllum Koenig 1928, assinalando a presença da primeira ordem, conforme já mencionado anteriormente, correspondia a plantas herbáceas, de hábito, provavelmente, sarmentoso (rastejante ou trepador) e constituiria a vegetação de substrato em ambiente hidro-higrófilo, típica de terras baixas, total ou parcialmente inundadas, conforme Dias-Fabricio (1983). Para McLoughlin (1992) Sphenophyllum rhodesii, entre outras formas, colonizou os habitats mais baixos e pantanosos de planície deltaica.

A Ordem Equisetales tem registrado sua presença através dos gêneros Paracalamites Zalessky 1927 e Koretrophyllites Radczenko 1955.

Paracalamites Zalessky 1927 trata-se de um morfo-gênero caulinar que pode estar associado a esfenófitas de habitats ligeiramente diferentes entre si desde mais higrófilas a mais higro-mesófilas.

Koretrophyllites Radczenko (1955), contrariamente estaria associado a regiões pouco úmidas, enquanto Andreis et al. (1980) associam-no a sedimentação lacustre na fazenda Goulart, RS. 
As Pteridospermales aparecem, na assembléia, representadas pelos gêneros Botrychiopsis (Carr.) Archangelsky \& Arrondo 1971, Eusphenopteris Novik 1947 e Nothorhacopteris (Geinitz) Archangelsky 1983. Essas formas, como mencionado acima, constituem comunidades higro-mesófilas a mesófilas. Conforme Retallack (1980), as planícies fluviais distribuídas em áreas pró-glaciais foram cobertas por bosques de Pteridospermas ou sotobosques de Botrychiopsis, conforme Cúneo (1986).

Quanto aos aspectos de hábito e habitat, pode-se dizer que, conforme Guerra-Sommer et al. (1986), B. plantiana teria porte arbuctivo com eixo central verticilado o que permitia certa estabilidade em solos de fundo de corpos de água associados a ambientes hidro-higrófilos. Seria, segundo esses autores, plantas adaptadas a águas mais estagnadas, relacionadas a regiões marginais de lagos e bacias interdistributárias deltaicas. Aliás, o habitat higrófilo para Botrychiopsis já fora também aventado por Archangelsky (1981) dada a presença de base de frondes (aflébia) e rizóides na localidade La Casilda, Chubut, Bacia Central Patagônica (formações Piedra Shotle e Nueva Lubecka).

Em 1989, Guerra-Sommer ressaltou que B. plantiana dominaria totalmente os nichos higrófilos em climas frios, pró-glaciais do Itararé, aparecendo em associação com esfenópsidas do tipo Phyllotheca na base da Formação Rio Bonito.

Archangelsky (1984) já havia se referido ao domínio de Botrychiopsis em associações de ambientes de tundra pró-glaciais no Carbonifero, caracterizados por monotonia floristica.

Retallack (1999) descreveu um ecossistema do tipo tundia para a Formação Seaham-unidade litoestratigráfica glacial do Sudeste da Austrália (New South Wales)- registrado em siltitos com traços de raizes fósseis de idade westfaliana (310312 M.a) na forma de paleossolos onde encontrou B. plantiana.

Argumenta ele que essa vegetação de tundra de Botrychiopsis teria surgido pela perda da maioria das plantas associadas, seguida de um certo nanismo de planta lenhosa do tipo B. plantiana. Assim, afirmou que um arbusto ou forma 
herbácea é compatível com o tamanho de algumas das raízes lenhosas nos paleossolos que produziram restos de B. plantiana.

Nothorhacopteris argentinica, de acordo com Archangelsky (1983 citando Retallack, 1980), é possivelmente um elemento higro-mesófilo importante na flora de pteridospermas, do Carbonífero médio vivendo em planícies fluviais pré-glaciais. Viveria nessas planícies ou próximo a comunidades dominadas por licófitas, junto a ambientes aquosos e formando pequenas comunidades arbustivas. Pode ser achada como espécie dominante ou exclusiva em uma tafoflora associada com licófitas anãs.

Entretanto, esse rião é o caso na tafoflora de Santa Marta onde aparece em evidente pequena freqüencia comparada com Botrychiopsis ou Eusphenopteris. Essa pequena freqüência e a ocorrência associada de aflébia são mais sugestivas de hábito higrófilo do que mesófilo na tafoflora Santa Marta. Outras espécies de Nothorhacopteris, tais como N. kellayberensis e N. szajonochai, parecem ter sido mais adaptadas a condições ambientais pró-glaciais e pós-glaciais.

Eusphenopteris Novik 1947 (conforme Cesari, 1986) e Cúneo (1986) apresenta possiveis exigências edáficas higro-mesófilas aparecendo em comunidades arbustivas de pteridospermas carboniferas gondvânicas como as de Formação Tupe (nas Províncias de La Rioja e San Juan- bacia de Paganzo) e da Formação Mojón de Hierro de Chubut (Bacia Central Patagônica).

As Cordaitales (Noeggerathiopsis) poderiam estar associadas tanto a comunidades hidro-higrófilas como a meso-xerófilas. Como não se conhece seus caules, nem tampouco suas folhas foram disponiveis para examiná-las, nada se pode inferir a partir delas. 
Resumindo essas informações teríamos o seguinte quadro:

\begin{tabular}{|c|c|c|c|c|c|}
\hline Generos & hidrm higrófila & Higrofila & Higyonnesofila & mesofias & meso-xerófitas \\
\hline Sphenohizyluth & $\begin{array}{l}\text { (tipo planjols } \\
\text { cestálca) }\end{array}$ & & & & \\
\hline Paracalamites & 1 & $\%$ & 6 & & \\
\hline Koretrophylftes & & & $\%$ & & \\
\hline Botrycriopsis & + & (finoras climas & (err rreas pro & $\bullet$ & \\
\hline Notho eoopters & & 12 & $\begin{array}{l}\text { (poderse } \\
\text { associlar a } \\
\text { icólías) }\end{array}$ & \% & \\
\hline Eusphenopteris & & & $\begin{array}{l}\text { (comunidades } \\
\text { arbustivas) }\end{array}$ & 8 & \\
\hline Noeggerathiopsis & $\%$ & & & & $\bullet ?$ \\
\hline & $\begin{array}{l}\text { planicle deltalca } \\
\text { possivelmente altoo }\end{array}$ & hes & preas ligeliame & nais elevedas & elevadas mais \\
\hline
\end{tabular}

VII.2. Quadro dos hábitos dó fitofósseis.

Em síntese, pode-se deduzir a partir dessa assembléia fitofossilifera que ali ficaram preservados:

-elementos de comunidades hidro-higrófilas e higrófilas que deveriam viver em áreas pantanosas (com alto nível de lençol freático) tipo planícies deltaicas e em áreas ribeirinhas (como as esfenófitas), que correspondiam a formas autóctones associadas a

-elementos de comunidades higro-mesófilas a mesófilas, que deveriam viver em áreas de solos pouco mais secos, tipo áreas interdistributárias ou algo mais elevadas a secas a montante do sistema fluvial correspondendo a formas alóctones. Entre última essas estariam alguns dos elementos gimnospérmicos.

\section{VIl.A3. Interpretações Paleofitogeograficas e Paleoclimáticas}

A distribuição global de plantas durante o Neopaleozóico (Carbonífero e Permiano) foi, paleogeograficamente, controlada conforme Meyen (1987). As reconstruções de distribuição mar-continente durante o Neopaleozóico coincidem 
com a formação de um enorme bloco continental, chamado Pangea, que se estendeu desde a zona temperada fria do hemisfério sul até a zona temperada fria do hemisfério norte. A distribuição das floras na Pangea variou de acordo com as paleolatitudes e, então, diferentes padrões emergiram seguindo sua mobilidade através do tempo, conforme Archangelsky (1990).

No início do Carbonífero, segundo Meyen (1987), dois grandes reinos florísticos podem ser reconhecidos sobre a Terra: o Reino Gondvânico envolvendo as floras das áreas continentais sulinas (Antártica, América do Sul, África com a placa Arábica, Oceania e Índia), e o Reino Arctocarbônico, compreendendo as áreas Euroamericana e Angárica.

No final do Carbonifero, há tendência para o aparecimento de províncias em ambos os reinos e a individualização do Reino Angárico. Dentro do Reino Gondvânico, durante o Neocarbonifero, duas províncias começam a se individualizar a Notoafroamericana envolvendo a América do Sul e a região centro-meridional da África e a Província Australoindiana envolvendo, Antártica, Oceania e Índia.

Durante o Westphaliano, a maior parte do Gondwana estava situada entre $30^{\circ}-60^{\circ} \mathrm{S}$, conforme Archangelsky (1990:111, Fig.9.25) e lannuzzi \& Rösler (2000, Fig.--). Na América do Sul, Africa e Austrália, desenvolveu-se uma flora característica com frondes de Nothorhacopteris, Botrychiopsis, Triphyllopteris, etc., licófitas tipo Bumbudendron, Mallanzania, Lepidodendropsis e gimnos! mas tipo Cordaites e Ginkgophyllum. As assembléias fitofossiliferas encontradas tanto no Gondwana Ocidental como Oriental são completamente diferentes das floras coevas de áreas tropicais. Na Venezuela, por exemplo, a flora "euroamericana" westfaliana incluia Neuropteris ovata, Lobatopteris vestita e Annularia, como foi observada por Odreman-Rivas e Wagner (1979 in Archangelsky \& Cúneo, 1991).

Foi durante o Mesocarbonífero (Namuriano-Westfaliano), conforme Archangelsky (1990) e Parrish (1990), que o continente gondvânico rotacionou no sentido horário, de tal forma que sua região oriental dirigiu-se para o pólo sul e a sua porção ocidental aproximou-se do Equador. O pólo sul foi circundado por grande massa continental, instalando-se uma persistente glaciação sobre a área meridional 
do antigo Gondwana. Com um centro de congelamento enorme, constantemente espalhando ar frio sobre a parte sul do continente, conseqüentemente, quase não há documentário fóssil além dos $60^{\circ} \mathrm{S}$. Assim, a maioria das ocorrências fitofossilíferas do Westfaliano gondvânico está situada entre $30-60^{\circ} \mathrm{S}$ e sua uniformidade não sugere um forte provincialismo.

Examinando os mapas paleogeográficos de Conti \& Raspalini (1993 in Azcuy \& Di Pasquo, 1999, p.246) nota-se que a área paulista na bacia do Paraná, durante - Carbonífero médio, estaria em latitude de aproximadamente $70^{\circ} \mathrm{S}$. Contudo, Scotese et al. (1999) colocam a bacia do Paraná numa latitude de $45^{\circ}$ Sul, durante o Permo-Carbonífero, e sob clima temperado frio.

A área de Itapeva, nos mapas de reconstituição paleogeográfica e paleoclimática no tempo Westfaliano-Estefaniano de Golonka et al. (1994, Fig.31 33), estaria situada em porção continental, de alta pressão atmosférica, submetida à temperctura média de $10^{\circ}$ a $15^{\circ}$.

Quanto às inferências paleoclimáticas que se podem extrair dessa assembléia fitofossilfiera tem-se que:

a) Houve um grande volume de fitomassa acumulada, que contribuiu para a formação de camadas carbonosas (autóctones ou levemente hipoautóctones), o que constituiria maior evidência de clima interglacial, relativamente mais quente, do que pró-glacial.

b) Embora a assembléia fitofossilifera estudada seja, relativamente, pequena (38 espécimes), sua diversidade é muito grande se considerar-se que corresponde a 14 espécies, o que equivale dizer quase três espécimes/espécie.

As espécies mais freqüentes na tafoflora, isto é, com mais de três espécimes, são:

cf. Eusphenopteris sp. -8 espécimes

Botrychiopsis plantiana - 6 espécimes

$P$. levis -4 espécimes

Paracalamites australis -3 espécimes

$P$. montemorensis -3 espécimes 


\section{Sphenophyllum rhodesii -3 espécimes}

Cordaicarpus zeillerii - 3 espécimes

Esse aspecto (número grande de espécies/número pequeno de espécimes) conforme diagrama apresentado por Rigby (1971:26, Fig.5) ou Bernardes-deOliveira (1977:62, Fig.20) é fortemente sugestivo de um clima tendendo a temperado para quente, o que corroboraria a idéia indicada pela formação de carvão.

Por outro lado, a presença de esfenófitas não muito desenvolvidas, isto é, microfanerofiticas, poderiam estar associadas a climas frios a temperados frios úmidos. Todavia Koretrophyllites, segundo Boureau (1964), apareceu em regiões temperadas pouco úmidas, de estações bem marcadas de Angara equanto as esfenofilales são, muitas vezes, associadas a climas mais quentes como propõem Cúneo et al. (1993) ao interpretar o paleoclima eopermiano da Patagônia. Logo, as esfenófitas em si parecem apresentar um antagonismo de evidências entre clima frios a temperados frios úmidos e climas temperados pouco úmidos ou mais quentes.

Botrychiopsis plantiana, por sua vez, tem sido considerada um componente de ecossistemas florestais do Carbonifero austral (constituindo sotobosques em ambiente hidro-higrófilo, conforme Cúneo 1986). Contudo, foi capaz de persistir mais ao sul à deteriorização climática intolerável a outras plantas, junto com Dichophyllites peruvianus. Quando o paleoclima melhorou, Botrichyopsis persistiu em diversas florestas do Permiano com Gangamopteris e Glossopteris. Assim, como bem sintetiza Guerra-Sommer (1983), a presença dominante de B. plantiana em sedimentos gondvânicos tem sido relacionável por vários autores a associações de clime muito frio do tipo "tundra", que evoluiram no tempo geológico para "taiga" de clima temperado-frio, em associação com glossopterídeas. Novamente, o que se pode detectar através da presença de B. plantiana é a sugestão de um clima muito frio a temperado frio.

Nothorhacopteris argentinica, de acordo com Archangelsky (1983), seria um elemento de clima temperado frio que viveu durante o Carbonifero até o Permiano 
inferior, sendo importante elemento também da flora carbonífera de pteridospermales em planície lagunar pré-glacial e pró-glacial.

A presença do gênero eopensilvaniano nórdico Eusphenopteris Novik na tafoflora de Santa Marta, poderia estar associada a migração desse elemento, em uma fase interglacial, com certo aquecimento climático, principalmente em se considerando ess gênero como o mais frequente na tafoflora (8 espécimes).

As formas cordaitaleanas tanto podem ser de zonas temperadas-frias como em Angara, ou tropicais-úmidas como na Flora Euroamericana.

A vegetaçăo regional, considerando-se a presença de Botrychiopsis e Nothorhacopteris, bem como todo contexto paleogeográfico e paleoclimático da bacia, apontam para um clima temperado frio. Por outro lado o maior acúmulo de material vegetal (carvão) e a diversidade florística apontem para um clima mais quente. Este fato pode ser explicado, provavelmente, como uma condição muito local, cujo clima ainda regionalmente frio seria amenizado pela proximidade com o ambiente marinho na qual sua presença foi detectada por Cabral Jr. \& Motta (1985:462).

\section{VII.B. Dados Microflorísticos}

\section{VII.B1. Afinidades Botânicas e Ecológicas}

Através das afinidades botânicas dos esporos e grãos de pólen dispersos nos sedimentos fitofossiliferos foi detectada a presença de esporos de licopsida e filicopsida e grãos de pólen de gimnospermopsida representadas por Coniferales e Pteridospermales (Quadro VI.3.). A presença de esfenópsidas na vegetação local denunciada por seus macrofósseis (Koretrophyllites, Sphenophyllum, Paracalamites) não estão aqui registradas do ponto de vista palinológico. Por outro lado, as licópsidas predominantes na assembléia palinológica, filicópsidas e coniferales, não se fazem presentes macroscopicamente.

As diferenças entre o documentário macro e o microflorístico poderiam ser explicadas com base em diversos fatores. 
Um fato a ser considerado refere-se à afinidade botânica de Botrychiopsis plantiana corresponder às Gimnospermopsidas /Pteridospermales (?). Nota-se que do ponto de vista dos macrofósseis essa forma encontra-se em relativa abundância, porém seus microfósseis são escassos e restritos aos Limitisporites. O domínio das Filicópsidas/Progimnospermópsidas na assembléia palinológica seria facilmente explicado se a afinidade botânica de $B$. plantiana fosse feita com esse grupo e não junto às Pteridospermales(?) conforme Maithy (1965), Artabe et al. (1987) e Cesari \& Garcia (1988) consideram.

\section{VII.B2. Interpretações Paleoecológicas}

A interpretação paleoambiental baseada em palinomorfos, segundio Dias (1993), é influenciada por fatores ecológicos como os climáticos e os ed́ficos que provocam modificações na flora, que por sua vez, reflete-se nas partes preservadas.

Segundo Dias (op. cit.), "particularmente os esporos e pólens, originados quase que exclusivamente de plantas de ambiente continental, são importantes indicadores das oscilações climáticas e ambientais".

Segundo Dias (op. cit.) ainda, o grupo das Pteridófitas é o principal responsável pela produção de esporos que possuem um sistema de dispersão de pequena amplitude. Em geral, são depositados próximos à planta mãe, ao contrário dos grãos de pólen e pré-pólens representadios aqui pelas gimnospermópsidas, que através de seus sacos aeriferos, torna o sistema de dispersão mais eficiente, sendo capaz de transportá-los a uma distância considerável.

A microflora registrada no presente trabaiho representa nichos diversificados com associações de plantas de ambiente hidro-higrófilos, hidro-mesófilo e mesófilo que seriam responsáveis pela variação da composição.

O ambiente hidro-higrófilo é constituído por uma vegetação composta por plantas aquáticas, Licópsidas, e algumas Gimnospermópsidas (Pteridospermales) que viveriam em terras baixas, total ou parcialmente inundadas.

$O$ ambiente higro-mesófilo é relacionado com terras altas e baixas, e estaria caracterizado por ambientes narginais aos pântanos e por lugares mais secos da 
planície deltaica ou aluvial. As filicópsidas e gimnospermópsidas (Coniferales e Pteridospermales) seriam as plantas que representariam este ambiente.

Nos ambientes mesófilos, caracterizados por terras altas, o tipo de vegetação dominante seria composto principalmente por gimnospermópsidas, como as Coniferales.

Outro fator a ser considerado é o fato de que a macroflora da Fazenda Santa Marta está representada sempre por plantas hidro-higrófilas que viveram próximas ao ambiente de deposição, enquanto a palinoflora estaria representando uma síntese da vegetação regional transportada por vento ou água e sedimentada no mesmo ambiente. A ausência de licópsidas como macrofóssil, se justificaria pelo fato destas plantas serem de ambientes costeiros.

Vale a pena ressaltar como já fez Césari (1986) que a presença de licópsidas e delicadas frondes de pteridospermas, nos indicam um clima não rigoroso. Além do mais, a presença constante do grupo de grãos de pólen monossacados e algumas espécies de esporos, através da seqüência Tupense, indicam a ausência de grandes mudanças climáticas.

\section{VII.C. Dados macro e microfloristicos na interpretação bio e cronoestratigráficas}

Analisando a distribuição estratigráfica gondvânica dos gêneros e espécies encontrados na tafoflora Santa Marta, foram feitas as observações que são registradas a seguir.

Primeiramente, observou-se as ocorrências dos elementos componentes dessa tafoflora por todo o Subgrupo Itararé (tafofloras A e transicional de Rösler, 1978), chegando-se ao quadro VII.3. abaixo: 


\begin{tabular}{|c|c|c|c|c|c|c|c|c|c|c|c|c|}
\hline TAFOFLORAS & \multicolumn{5}{|c|}{$\mathbf{A}$} & \multicolumn{7}{|c|}{ TRANSICIONAL } \\
\hline LITOESTRATIGRAFIA & \multicolumn{12}{|c|}{ GRUPO TUBARÃO } \\
\hline $\begin{array}{c}\text { LOCALIZAÇÃO } \\
\text { GEOGRÁFICA }\end{array}$ & \multicolumn{12}{|c|}{ SUBGRUPO ITARARÉ } \\
\hline Publicações & $T$ & 2 & $\sqrt{3}$ & 4 & 5 & 6 & 7 & 8 & 9 & 10 & $\overline{11}$ & 12 \\
\hline TAXAS & 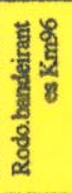 & 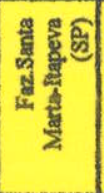 & 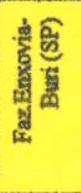 & 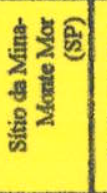 & 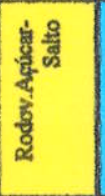 & 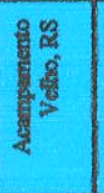 & 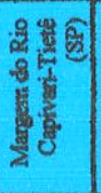 & 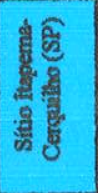 & 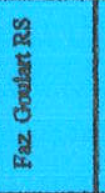 & $\frac{a}{3}$ & 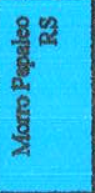 & 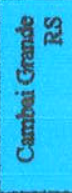 \\
\hline Sphenophyllum sp. & & $\cdot$ & & \$ & & & & & & & & \\
\hline S. cf. S. churulianum & & - & & & & & & & & & & \\
\hline S. cf. S. rhodesii & & $\bullet$ & & & & & & & & & & \\
\hline cf.Koretrophyllites sp. & & - & & & & & & & $\div$ & & & \\
\hline $\begin{array}{l}\text { Paracalamites } \\
\text { australis }\end{array}$ & & - & & $\bullet$ & $\bullet$ & - & - & - & & - & $\cdot$ & \\
\hline P. montemorensis & & $\bullet$ & & $\cdot$ & & & & & & & & \\
\hline P. levis & & - & & - & & & & & & & & \\
\hline P. sp. & & $\bullet$ & & $\bullet$ & & & & & & & & \\
\hline $\begin{array}{l}\text { Botrychiopsis } \\
\text { plantiana }\end{array}$ & & - & & $\bullet$ & & - & & & - & & & \\
\hline cf. Eusphenopteris sp. & & $\cdot$ & & & & & & & & & & \\
\hline $\begin{array}{l}\text { Nothorhacopteris cf. } \\
\text { N. argentinica }\end{array}$ & & $\cdot$ & 8 & 이 & & & & & & & & \\
\hline $\begin{array}{l}\text { Aflébia de cf. } N \text {. } \\
\text { argentinica }\end{array}$ & & - & & & & & & & & & & \\
\hline Noeggerathiopsis sp. & & $\bullet$ & & of & 이 & of & 0 & 0 & of & $\$$ & & 8 \\
\hline Cordaicarpus zeilleri & & - & & 0 & 0 & & of & 0 & of & 8 & & 8 \\
\hline $\begin{array}{l}\text { Samaropsis } \\
\text { itapevensis }\end{array}$ & & $\cdot$ & & of & of & & of & 의 & & & & \\
\hline Legenda: & $\begin{array}{l}\text { Gên } \\
\text { Gên } \\
\text { sp. }\end{array}$ & espe & & & & & & & & & & \\
\hline
\end{tabular}

Tafofloras A $\square$

Transicional $\square$

1. Amaral (2000, inédito)

2. Zampirolli \& Bernardes-de-Oliveira (1999a,b), Zampirolli et al. (1999a, b), Zampirolli et al. (2000) e Zampirolli \&

Bernardes-de-Oliveira (2000)

3. Perinotto \& Rösler (1987)

\author{
4. Millan $(1975,1987 a)$ \\ 5. Bernardes-de-Oliveira et al. (2000) \\ 6. Guerra-Sommer \& Cazulo-Klepizig \\ (1981)
}

7. Rohn et al. (2000)

8. Millan $\left(1987^{\mathrm{a}}\right)$

$9-12$. Guerra-Sommer \& CazuloKlepizig (1981)

Quadro VII.3. Distribuição estratigráfica dos taxas da tafoflora Santa Marta no Subgrupo Itararć. 
Verifica-se neste quadro, que alguns elementos ocorrem exclusivamente na fazenda Santa Marta como, por exemplo, Sphenophyllum cf. S. churulianum, $S$. cf. $S$. rhodesii, cf. Eusphenopteris sp., Aflébia cf. Nothorhacopteris argentinica, Cordaicarpus zeilleri e Samaropsis itapevensis. Provavelmente, essa aparente exclusividade seja decorrente de uma falta de conhecimento mais detalhado das outras tafofloras ou por razões paleoecológicas.

Ainda, por esse quadro salienta-se que a composição tafoflorística de Santa Marta apresenta mais elementos específicos em comum com a tafoflora do Sítio da Mina em Monte Mor (SP). São as duas únicas localidades do Subgrupo Itararé a compartilharem a ocorrência do gênero Sphenophyllum das espécies Paracalamites Levis, P. montemorensis. O gênero Nothorhacopteris é compartilhado também com a fazenda Enxovia-Buri. Essas três assembléias constituem parte integrante da associação tafoflorística A de Rösler (1978) ou Botrychiopsis/Nothorhacoptcris/Bumbudendron Bernardes-de-Oliveira et al. (2001a e b).

A tafoflora de Goulart (São Jerônimo, RS) com protoglossopterideas, estratigraficamente posicionada na parte superior do Subgrupo Itararé, foi considerada por Andreis et al. (1980) como eopermiana, apesar da ausência de Glossopteris e Gangamopteris ser fortemente sugestiva de uma idade mais antiga.

Se esse posicionamento estratigráicico for correto, a ocorrência de Koretrophyllites na área de Itapeva, porção médio-inferior do Subgrupo Itaráré, em vista da ausência de protoglossopterídeas do tipo-Rubidgea, porém associada a Botrychiopsis e Nothorhacopteris, poderia ser mais antiga que aquela da Fazenda Goulart (S. Jerônimo, RS) e mesmo a mais antiga ocorrência para todo o Gondwana.

A seguir, passa-se a uma análise mais ampla da distribuição desses elementos tafoflorísticos de Santa Marta, em relação às demais bacias gondvânicas.

O gênero Sphenophyllum encontra-se documentado no Paleozóico superior do Brasil, Argentina, África e Austrália. As espécies de S. cf. S churulianum, S. cf. S. rhodesii e S. sp. têm sua distribuição estratigráfica e geográfica, conforme dados de Cúneo et al. (1993) aqui complementados, resumidos no quadro VII.4. abaixo: 


\begin{tabular}{|c|c|c|}
\hline Especies & Corbonífero superior & Permiano inferior \\
\hline S cl. Sphenophyllum & $.1 .1 .1 .1 .1 .$, & 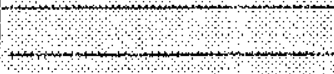 \\
\hline churullianum & 1,1 & 2 \\
\hline S of Sphenophyllum & & . \\
\hline thodesil & 12 & 3 \\
\hline$S . s p$ & 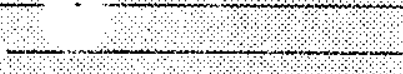 & \\
\hline & 1.1 & \\
\hline
\end{tabular}

Brasil Bacia do Paraná

1.1. Subgrupo Itararé-

Itapeva- (SP)- Westfaliano

Millan (1995)

1.2. Subgrupo ltararé-ltapeva- (SP)

(Westfaliano) neste trabalho

India East Raniganji Coalfield

2. Formação Barakar (Artinskiano)

Churulia (West Bengal) Srivastava

\& Rigby (1983)

Austrália Bacia de Perth 3. Irwin River Coal Measures

(Artinskiano) McLoughlin \& Drinnan

(1992) e Rigby (in Skwarko 1993)

VII.4. Quadro de distribuição estratigráfica do gênero Sphenophyllum

Há que se ressaltar aqui que o gênero Sphenophyllum, tipicamente permiano para as demais bacias gondvânicas, aparece já em rochas carboniferas (westfalianas) apenas na bacia do Paraná.

O gênero Paracalamites possui distribuição cosmopolita nas províncias Angárica e Gondvânica, ocorrendo desde o Carbonífero médio ao Permiano superior. A espécie $P$. australis seria a de distribuição estratigráfica mais ampla na Bacia do Paraná, desde Carbonifero médio a Permiano superior. Ocorre também na Argentina, desde Westfaliano até Sakmariano, nas bacias de Paganzo (formações Tupe-Westfaliano-Stefaniano; Andapaico-Carbonífero; de La Colina-Sakmariano; Tasa Cuna (Asseliano-Sakmariano); de San Rafael (Formação El Imperial- 
Namuriano-Asseliano) e de Calingasta-Uspallata (Formação Santa ElenaStefaniano-Asseliano/Sakmariano) e na Austrália, desde o Sakmariano ao Kazaniano, nas bacias de Perth (Formações Irwin River Coal Measures e Wagina Sandstone-Artinskiano); de Collie (Artinskiano-Kunguriano) e de Canning (Sakmariano), segundo Rigby (1966a) e Cúneo (1986). P. levis ocorre no Carbonifero superior do Brasil e na bacia de Paganzo (Formação Andapaico) Carbonifero da Argentina e na bacia de Perth (Irwin River Coal Measures e Wagina Sandstone) Artinskiano da Austrália, conforme Rigby (in Swarko 1993) e P. montemorensis ocorre somente em estratos westfalianos do Brasil, até o momento.

Verificanse que Botrychiopsis plantiana (Carr.) Archangelsky \& Arrondo 1971 apresenta uma distribuição mais comum no Gondwana Ocidental (América do Sul e África) mas ocorre também na Austrália Oriental. Tem registro nas seguintes bacias e unidades litoestratigráficas:

1) Bacia do Paraná - Subgrupo ltararé- em São Paulo nas tafofloras de Monte Mor e Itapeva (Millan, 1979, 1987b) e no Rio Grande do Sul nas talifloras da Fazenda Goulart e Acampamento Velho (Andreis et al. 1980; Cazzulo-Klepsig et al. 1980; Guerri Sommer et al. 1981), Vide Quadro VII.5. Na Formação Rio Bonito no Rio Grande do Sul, aparece na tafoflora de Morro Papaleo (Mariana Pimentel), segundo Pasqualini et al. (1986) e Guerra-Sommer (1989).

2) Bacia de Paganzo- FormaçãoTupe (Westfaliano-Stefaniano) em San Juan, tafoflora de Cienaga del Vall ito (Artabe et al. 1987); Formação El Trampeadero (Westialiana) em La Rioja, tafoflora Sierra de Ambato e Quebrada de La Cébila (Archangelsky, 1978); Formação Totoral (Westfaliano), em La Rioja, tafoflora de Sierra de Los Llanos (Archangelsky \& Arrondo, 1971); Formação Libertad (Estef: niano), em La Rioja tafoflora de Sierra de Vellazco Dique de Los Sauces (Archangelsky \& Arrondo, 1971); Formação Tasa Cuna (Asseliano-Sakmariano), em Córdoba tafoflora de Sierras de Córdoba; Formação Bajo de Los Vélez (Sakmariano), em San Luis tafoflora de Los Vélez de acordo (Archangelsky \& Cúneo, 1981). 
3) Bacia Central Patagônica." Formação Nueva Lubecka (SakmarianoArtinskiano), em Chubut tafoflora de Estamia La Casilda (Archangelsky \& Arrondo, 1971).

4) Bacia do Karroo Norte-Formação Vryheid (Ecca Médio-Artinskiano) no Transvaal, tafoflora de Vereeniging e Leeukui- (Anderson \& Anderson, 1985).

5) Bacia de New South Wales- Formação Seaham (Westfalian B-C Europa) Hunter Valley (Retallack, 1999).

\begin{tabular}{|c|c|c|}
\hline Espécle & Carbonifero superior & Permiano inferior \\
\hline \multirow[t]{2}{*}{ Botrychiopsis plantiana } & & \\
\hline & 12. & 123.45 \\
\hline
\end{tabular}

VII.5. Quadro de Distribuição estratigráfica da espécie Botrychiopsis plantiana.

Do ponto de vista cronoestratigráfico B. plantiana tem uma ampla distribuição desde Neocarbonifero até Eopermiano apresentando-se em floras préglossopterídeas como de Monte Mor e posteriormente em floras proto e glossopterídeas como fazenda Goulart.

Embora tenha sido considerada como provável descendente de $B$. weissiana por Archangelsky \& Arrondo (1971, p.223 Quadro 2), em algumas tafofloras neocarboníferas iniciais (westialianas) tais como a de Monte Mor, SP (Millan, 1975b e 1979) e Sierra de Ambato, La Rioja (Archangelsky, 1978) registra certa coetaneidade $\operatorname{com} B$. Wessiana, possivelmente no final da existencia desta última. Aparece nesses niveis, na Flora de Nothorhacopteris/Botrichyopsis/Ginkgophyllum associada a Bumbudendron, Malanzania, Brasilodendron, Paracalamites, Noeggerathiopsis, Fedekurtzia, Bergiopteris, etc conforme Archangelsky (1984), numa vegetação anterior àquela das proto e das glossopterídeas. Suas palinofloras associadas têm um predomínio de esporos apresentando os primeiros grãos de pólen monossacados do tipo Potonieisporites, Plicatipollenites e Caheniassaccites. Persive, contudo, nos estratos superiores ern associações com floras de protoglossopterídeas e glossopterideas tais como nas tafofloras do Rio Grande de Sul (Subgrupo Itararé e base da Formação Rio Bonito). Portanto, B. plantiana 
apareceu antes da existência das glossopterídeas e perdura até as etapas iniciais do Permiano com o advento das mesmas.

O gênero Nothorhacopteris tem sua distribuição estratigráfica na Argentina, Bolivia, Perú, Brasil e Austrália do Carbonífero inferior ao Permiano inferior. A espécie Nothorhacopteris argentinica aparece no Carbonífero inferior do Perú e no Carbonifero superior da Argentina e do Brasil (lannuzzi \& Rösler 2000). Suas ocorrências e suas respectivas bacias estão destacadas no Quadro VII.6. abaixo:

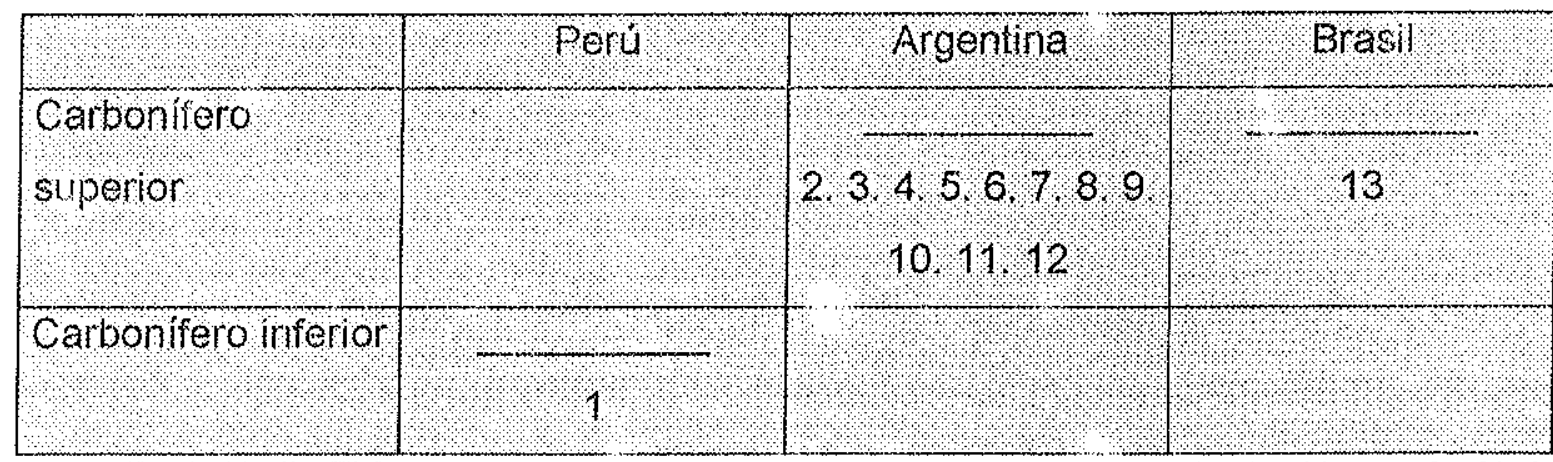

Bacia Tarija-Titicaca

1. Formação Ambo (Viseano) Perú, Doubinger \& Alvárez Ramis, 1980; Azcuy, 1991.

Bacia Paganzo

2. Formação Tupe (Estefaniano) setor do rio Francia, Cuerda \& Furque, 1981 e Bosi \& Andreis, 1985;

3. Formação Tupe (Estefaniano), Frenguelli 1943; Césari, 1986; Ottone e Azcuy, 1986; Cesari \& Limarino, 1987;

4. Formação Lagares (Westfaliano-Estefaniano), Moreli et al. 1984;

Subbacia Rio Blanco

5. Formação Quebrada Larga (Westfaliano-Estefaniano), Scalabrini Ortiz, 1973;

6. Formação Rio del Penõn (Estefaniano-Asseliano), González \& Bossi, 1986;

7. Formação Cortaderas (Namuriano), Azcuy et al. 1987; Carrizo, 1990;

8. Formação C. Agua Negra (Estefaniano) Gutiérrez, 1984; Carrizo, 1987;

Subbacia Caligasta-Uspallata 9. Formação Ansilta (Artinskiano-Kunguriano); Noriega, 1987 ;

10. Formação El Retamo (Estefaniano) Mésigos, 1953; Carrizo (198\%, 1990);

11. Formação Santa Máxima (Estefaniano) Ottone, 1987; 
12. Formação Tramojo (Sakmariano-Artinskiano) Archangelsky

\& Archangelsky, 1987;

\section{Bacia do Paraná}

13. Subgrupo Itararé- Itapeva (Westfaliano) Millan, 1995;

VII.6. Quadro de distribuição estratigráfica da espécie Nothomacopteris argentinica.

-Na América do Sul setentrional- flora de Nothorhacopteris (Carbonífero inferior)-

Eusphenopteris sp.- Peru Península de Paracas Sul do Peru-Grupo Ambo (Viseano)- lanuzzi \& Rösler (2000);

Eusphenopteris cf. E. neuropteroides - Venezuela-Andes-Venezuelanos Formação Carache (Viseano?)- lanuzzi \& Rösler (2000);

- Na América do Sul meridional- flora de Nothorhacopteris (Carbonífero superior)-

Eusphenopteris sanjuanina - Argentina- Bacia Paganzo- Formação Tupe (Westfaliano-Estefaniano); Formação Jejenes (Westfaliano), Césari (1986); Formação Água Colorada (Namuriano)- lanuzzi \& Rösler (2000);

Eusphenopteris cf. E obtusiloba- Argentina- Bacia Central-PatagônicaFormação Mojón de Hierro (Westfaliano) Sierra de Tepuel, Província de Chubut, Cúneo (1990).

Dentre essas formas, os espécimes da tafoflora Santa Marta comparam-se melhor com a última espécie de idade provavelmente Westfaliana-Estefaniana.

A porção basal daFormação Mojón de Hierro (Arroyo Garrido-bacia CentraPatagônica) estaria entre a Formação Jaramillo (Carbonifero inferior-bacia de Tepuel-Genoa com flora de Archeosigillaria) e porção superior da Formação Mojón de Hierro mais a Formação Rio Genoa (bacia Central-Patagônica) com flora Lubekense do Permiano inferior. Corresponderia a uma flora pré-Lubekense, de idade neocarbonífera, onde se mesclam (na Patagônia) pteridospermas de afinidades nórdicas (Eusphenopteris) com elementos gondvânicos como Nothorhacopteris e Botrychiopteris, sugerindo prováveis fenômenos migratórios anteriores à flora Lubekense $\mathrm{A}$ do Permiano inferior.

As espécies de Noeggerathiopsis estão presentes nas floras da América do Sul, desde o Carbonífero superior (Westfaliano) até Permiano inferior (Artinkiskiano- 
Kunguriano), Rösler, 1978; Archangelsky \& Azcuy, 1985; Rocha-Campos \& Archangelsky (S/a), ocorrendo em assembléias dominadas por Nothorhacopteris e Botrychiopsis.

Tomando-se como base as correlações estratigráficas estabelecidas por lannuzzi \& Rösler (2000, Fig.4), aqui no Quadro VIl.7. restritas às bacias da área meridional da América do Sul, e as respectivas composições tafoflorísticas de cada formação ai representadas, chega-se à conclusão que a tafoflora Santa Marta tem mais afinidades de associação florísticas com as formações Tupe/Guanadacol/Água Colorada/El Imperial e base de Mojón de Hierro, consideradas ai como westfalianas.

Por todas as características de sua associação acima referidas, sugere ser correlata à zona NBG da Argentina e à zona Nothorhacopteris-Sphenopteridium da Austrália, consideradas Carbonífero "médio-tardio" (Tupense) por Archangelsky \& Cúneo (1991).

A Formação Tupe, aflorante na Mina La Negra (Sierra de Maz), é proposta como holoestratotipo da zona NBG (Nothorhacopteris-BotrychiopsisGynkgophyllum), por Archangelsky \& Cúneo (1991).

A distribuição estratigráfica macrofitoflorística da tafoflora Santa Marta se encontra resumida no quadro VII.8. abaixo: 
---. Ocorrência da América do Sul / Setentrional ou outros continentes gondvânicos

- Ocorrência da América do Sul / Meridional

- Maior número de ocorrências da América do Sul / Meridional

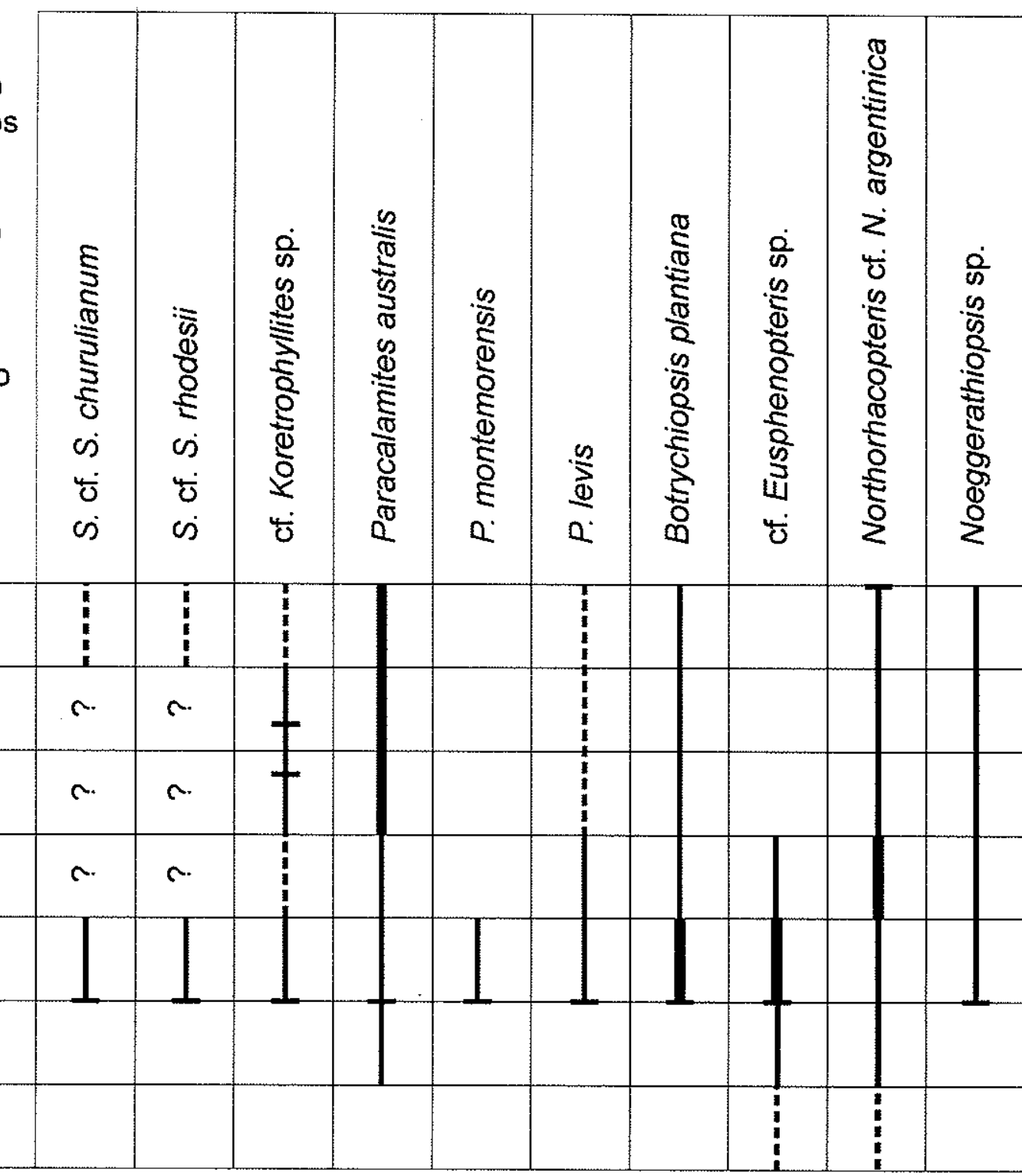

Quadro VII.7 - Distribuição estratigráfica da tafoflora Santa Marta, Itapeva (SP). 


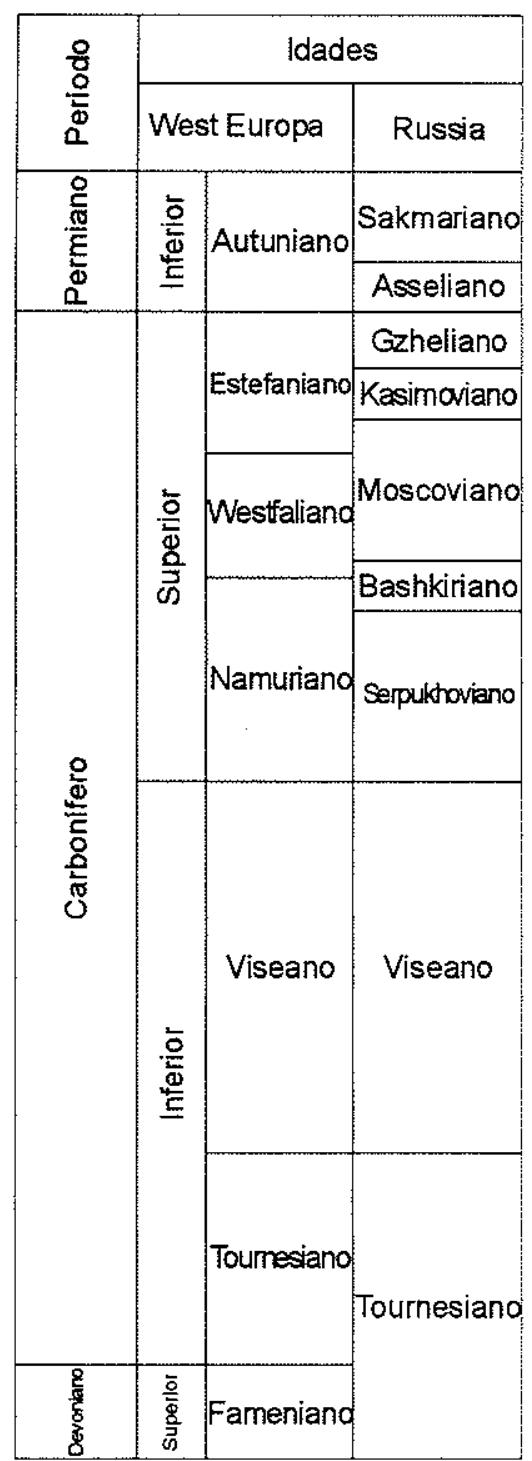

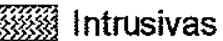

Tufos

Depósitos glaciais

Folhelhos pós-glaciais

Camadas de carvão

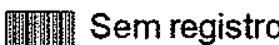
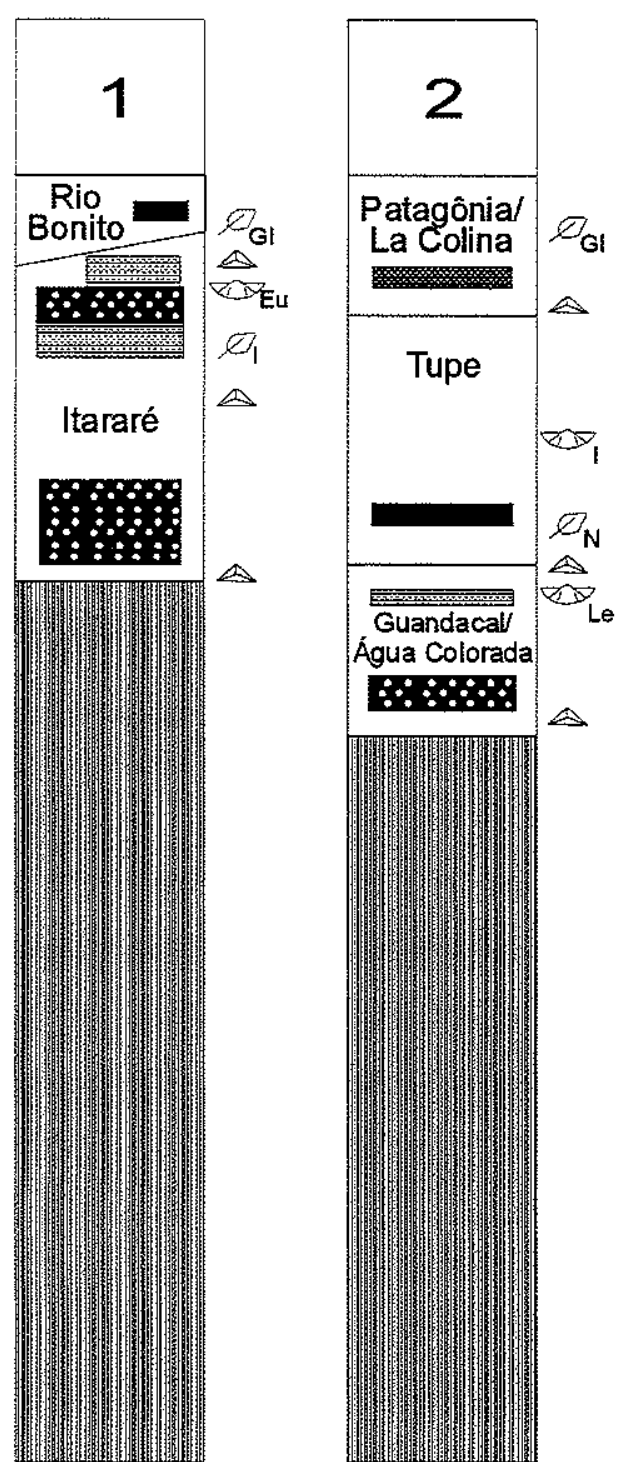

1 - Bacia do Paraná (Brasil)

2 - Bacia de Paganzo (Argentina) - La Rioja/San Juan

3 - Bacia Callingasta Uspallata (Argentina) - San Juan/Mendoza

4 - Bacia Rio Blanco (Argentina) - Catamarca/La Rioja/San Juan

5 - Bacia San Rafael (Argentina)

6 - Bacia Central Patagônica (Argentina)
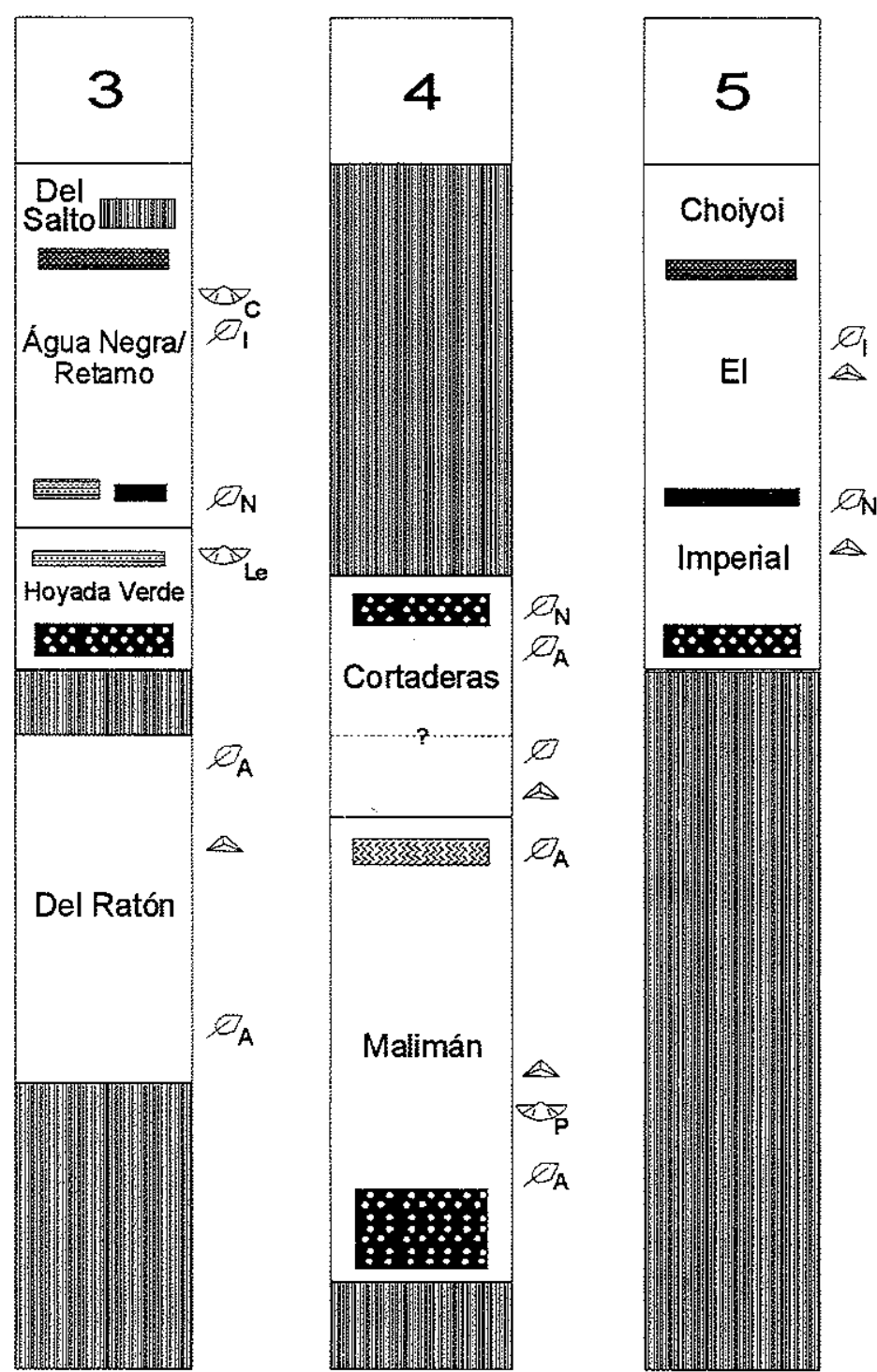

6

Rio Genoa

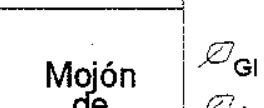

Hierro

(1)

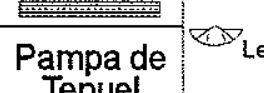

Tepuel

$\therefore \therefore \%$

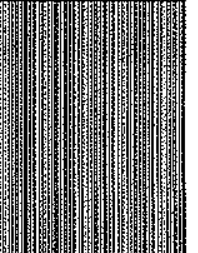

Jaramillo/

Valle Chico

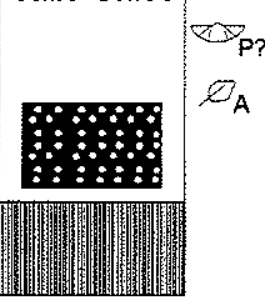

Legenda: Abreviaçöes

A) Floras: A, Archaeosigillaria-Lepidodendropsis-Frenguellia; N, Nothorhacopteris; E Euroamericana; I, Zona intervalo; Gi, 'Gigantopteris'; Gl, Glossopteris.

B) Faunas: P, Protocanites; Le, Levipustula; I, Intervalo; Ca, Cancrinela; E, Eurydesma $\emptyset$ Fitofósseis $\Delta$ Palinomorfos Faunas marinhas fósseis

Quadro VII.8 - Migração florística na América do Sul durante o Carbonífero: Implicações fitogeográficas e bioestratigráficas (modificado de lannı \& Röesler, 2000). 
Em síntese, concluí-se observando esse quadro de distribuição estratigráfica dos elementoos dessa tafoflora, que a porção inferior (Westfaliano) para a América do Sul-S, é marcada através das espécies Noeggerathiopsis sp., Paracalamites levis, cf. Eusphenopteris sp. e Nothorhacopteris cf. N. argentinica; e a porção superior (Estefaniana) por cf. Eusphenopteris sp. Contudo, a nítida abundância de Botrychiopsis plantiana, Eusphenopteris sp. e Nothorhacopteris cf. N. argentinica durante o Westfaliano é mais sugestiva dessa idade.

A posição cronoestratigráfica neocarbonifera (Westfaliana) da assembléia macrofitoflorística de Itapeva (SP), em que ocorre esses elementos, é corroborada pelos dados palinomórficos pertencentes a Zona Biointervalo Ahrensisporites cristatus que se refere à porção inferior do Subgrupo Itararé como foi determinado por Zampirolli et al. (2000) e Souza (2000, inédito). 
CAPÍTULO VIII 


\section{CONCLUSŌES GERAIS}

\section{VIII.1. Conclusões}

Os macrofitofósseis estudados, apesar de aparecerem apenas como impressões delicada, fragmentadas em matriz siltico-argilosa fortemente intemperizada, permitiram algumas inferências de ordem sistemática, tafonômica, paleoecológica, paleogeográfica, paleoclimatológica, estratigráfica, bio e cronoestratigráficas, fazendo com que os objetivos propostos tenham sido, se não plenamente, em sua maioria, atingidos.

Assim, a partir do exposto ao longo da dissertação, algumas conclusões gerais podem ser estabelecidas:

Do ponto de vista sistemático- conforme se observa no quadro $V .1,0$ estudo da assembléia (Coleção do Museu Nacional/UFRJ mais Coleção do IGc/USP) permitiu uma ampliação da lista de componentes tafofloristicos, com a detecção total de 15 formas distintas contra apenas 8 formas detectadas em estudos paleobotânicos realizados anteriormente.

Dentre essas formas, embora nenhuma espécie nova tenha sido proposta, foi possivel registrar a presença de mais:

-um gênero inédito para a bacia do Paraná- cf. Eusphenopteris sp.; -um gênero inédito para o Subgrupo Itararé do Estado de São Paulo- cf. Koretrophyllites $\mathrm{sp}$;;

-duas espécies de Paracalamites (inéditas para a fazenda Santa Marta), além de $P$. australis já registrada. Para as três espécies são propostas novas emendas no sentido de melhor delimitar a diagnose específica;

-uma outra espécie de Sphenophyllum inédita para a bacia do Paraná- $S$ cf. S. rhodesii.

-uma aflébia de Nothorhacopteris cf. $N$. argentinica- órgäo foliar näo observado, anteriormente, na bacia do Paraná. 
Essa ampliação de lista permitiu constatar que a assembléia é muito mais variada do que se cria, anteriormente, e composta basicamente de: esfenópsidas, progimnospermópsidas e gimnospermópsidas (Cordaitales e Pteridospermales).

A assembléia palinológica, com 19 formas distintas, confirma essa moderada diversificação florística, embora consideradas as afinidades botânicas, os grupos preservados não sejam exatamente os mesmos. Nesse caso, conforme Fig.VI.3 temse: Licópsidas (mais abundantes), Filicópsidas (podendo ai estarem incluidas progimnospermópsidas???) e gimnospermópsidas (Pteridospermales e Coniferales). Essa aparente discrepância de dados poderia estar associada à problemática de que os macrofitofósseis representam a vegetação extremamente local ou próxima ao ambiente de deposição, enquanto a palinológica registraria a vegetação regional ou de uma área mais ampla.

Do ponto de vista tafonômico- esses fitofósseis, representando formas vegetais em sua maioria higrófilas, foram depositados sem uma direção preferencial. Sugerem pequeno transporte mas suficiente para fragmentá-los muito, dada a sua natureza frágil.

A assembléia fitofossilifera composta por fragmentos de folhas, caules e sementes, abundantemente acumulados, originando, camadas de carvão, pode indicar, um ambiente aquoso, redutor, onde se acumulavam formas higrófilas, higromesófilas e prováveis mesófilas corroborando com a idéia de autoctonia associada a curta ou pequena aloctonia.

Do ponto de vista paleoecológico- a macroflora em consideração, apresenta elementos típicos de fácies hidro-higrófilas a higrófilas, depositadas em associação com alguns elementos mesofílicos, num contexto geológico regional glácio-flúvio-deltaico que, localmente, é sugestivo de ambiente interglaciallagunar/de planície deltáica. A microflora representa, mais eqüitativamente, a associação de elemento de diversos nichos dos ambientes hidro-higrófilos a mesófilos.

Do ponto de vista paleogeográfico e paleoclimático- a tafoflora apresentando elementos florísticos em comum com as áreas gondvânicas 
Ocidentais (Argentina) e Orientais (Austrália, Índia) como, por exemplo, Botrychiopsis plantiana, Nothorhacopteris argentinica, S. cf. S. churulianum, evidenciaria um certo provincialismo bem pouco definido.

As presenças de cf. Eusphenopteris sp., do gênero Nothorhacopteris que são registradas na área setentrional da América do Sul, durante o Eocarbonifero, ocorrem aqui no Neocarbonifero, evidenciando uma certa migração translatitudinal, da área estudada em direção ao equador, e florística, no sentido contrário (equador para o pólo), resultante da rotação no sentido horário de todo o Gondwana durante o Westfaliano.

Dado o grande volume de fitomassa acumulada, que constitui a formação de camadas de carvão (autóctones ou levemente hipoautóctones) mais a relativa diversificação das espécies componentes da assembléia há uma forte sugestão para clima temperado moderado ou provavelmente menos rigoroso de um estágio interglacial. Essa evidência paleoclimática corrobora a posição paleolatidudinal dada por paleomagnetismo que coloca essa área entre $30^{\circ}$ e $60^{\circ} \mathrm{S}$, no Carbonifero superior inicial.

Do ponto de vista sedimentológico e estratigráfico- As litologias e estruturas ritmicas assemelham-se àquelas descritas para deposição em planície deltaica, com acúmulo de material lenhoso e macrofitofósseis, apontados por Cabral Jr. \& Motta (1985).

A assembléia estudada como foi visto, é proveniente da unidade faciológica $B$ (de Cabral Jr. \& Motta, 1985), unidade hulheifera do Subgrupo Itararé, aflorante na área de Itapeva, SP. Um "horst", elevado toda a região, expondo os niveis mais basais do Subgrupo Itararé (unidades A e B de Cabral Jr. \& Motta, 1985) na área, A composição microflorística do nível fitofossilífero aponta para um posicionamento bioestratigráfico na palinozona de intervalo (Ahrensisporites cristatus) mais inferior do Subgrupo Itararé no Estado de São Paulo (Zampirolli et al., 2000 e neste trabalho). Pode-se então concluir que, o nivel fossilifero estudado (do sítio paleontológico) está situado na porção mediano-basal do Subgrupo ttararé e não mediano-superior como alegam alguns estratigrafos. 
Do ponto de vista bio e cronoestratigráfico- a tafoflora Santa Marta é considerada neocarbonifera, de provável idade westfaliana, com base em seus elementos megaflorísticos, comparáveis àqueles das associações da Zona NBG da Argentina de Archangelsky \& Cúneo (1991). Em seu conteúdo palinológico é posicionada à Zona Biointervalo Ahrensisporites cristatus de Souza (2000, inédito). Constitui parte integrante da tafoflora A, dentro da sucessão paleoflorística proposta por Rösler (1978) para a bacia do Paraná ou da associação Botrychiopsis, Nothorhacopteris, Bunbudendron da sucessão paleoflorística, informalmente proposta por Bernardes-de-Oliveira (2001a e b) para o Subgrupo Itararé, no Estado de São Paulo. Assim, corresponde a uma flora gondvânica interglacial préglossopterídeas. 
REFERÊNCIAS BIBLIOGRÁFICAS 
CAPITULO IX. REFERENCIAS BIBLIOGRAFICAS

AMARAL, P.C. 2000. Estudo da Tafoflora do Subgrupo Itararé, no afloramento $\mathrm{Km} 96 \mathrm{da}$ Rodovia dos Bandeirantes, Municipio de Campinas, SP. Monografia de trabalho de Formatura, IGc/USP, p. 130.

ANDERSON, J.M. \& ANDERSON, H.M. 1985. Paleoflora of southern Africa: Prodomus of southern African megafloras Devonian to Lower Cretaceous. Published for the Botanical Reseach Int. by A.A. Balkema/Rotterdam. p. 149.

ANDREIS, R. R.; CAZZULO-KLEPZIG M.; GUERRA-SOMMER, M. \& MARQUES-TOIGO, M. 1979. Interpretação paleoambiental e estudo paleobotânico e palinológico do Grupo Itararé na área Faxinal, municipio de Guaiba, RS. IX. SIMPÓSIO DE GEOLOGIA DO NORDESTE-NATAL.

ANDREIS, R. R.; CAZZULO-KLEPZIG M.; GUERRA-SOMMER, M. \& ZIMERMANN, L. 1980. Considerações sobre um afloramento fossilifero do Grupo Itararé, Fazenda Goulart, Francisquinho, Município de São Jerônimo, RS. Boletim /G/USP, II:85-97.

ARAl, M. 1980. Contribuição dos pólens estriados na bioestratigrafia neopaleozóica da parte nordeste da Bacia do Paraná. Boletim IG-USP, São Paulo, 11:98-105.

ARBER, E.A.N. 1902. On the Clarke collection of fossil plants from New South Wales. Q.J. Geol. Soc., 58:1-26 (1 pl.)

ARBER, E. A. N., 1905. Catalogue of the fossil plants of the Glossopteris Flora. Department of Geology, British Museum (Natural History), London, 1-255, 8 láms.

ARCHANGELSKY, S. 1958. Estúdio Geológico y Paleontológico del Bajo de La Leona (Santa Cruz). Acta Geologia Lillioana. 2(5-133) Lám.

ARCHANGELSKY, S. 1977. El género Bergiopteris Kurtz, del Carbónico superior de la Cuenca Paganzo, Argentina. Bol. Asoc. Latinoam Paleobot. Palinol. 4:11-24.

ARCHANGELSKY, S. 1978. Nuevo Elementos Paleoflorísticos De La Formacion Trampeadero (Carbonico) Sierra de Ambato, Provincia de La Rioja. Ameghiniana XV (3-4):429-439.

ARCHANGELSKY, S. 1981. Fedekurtzia, a new Carboniferous frond from Gondwanaland and its fructification. Am. J. Bot., 68 (8):1130-1138.

ARCHANGELSKY, S. 1983. Nothorhacopteris, a new generic name for some Carboniferous monopinnate fronds of Gondwanaland (Rhacopteris ovata auct and Pseudorhacopteris Rigby 1973)- ver Palaeobot. Palynol. 38 (3-4):157-172. 
ARCHANGELSKY, S. 1984. Floras Neopaleozoicas del Gondwana y ser zonación estratigráfica. Aspectos Paleogeográficos conexos. Comum. Serv. Geol. Protugal 70(2):135-150.

ARCHANGELSKY, S. 1990. Plant distribuition in Gondwana during in the late Paleozoic. in TAYLOR, T.N. \& TAYLOR, E.L., Editors. Antartic Paleobiology. Springer Verlag, p.102117.

ARCHANGELSKY, A. \& ARCHANGELSKY, S. 1987. Tafoflora de la formacion Tramojo, Paleozoico tardio, en la region de Uspallata, provincia de Mendoza, República Argentina. Ameghiniana 24 (3-4):251-256.

ARCHANGELSKY, S. \& ARRONDO, O.G. 1971. Palaeophytologia Kurtziana III. 2. Estudio sobre el género Botrychiopsis Kurtz ( $=$ Gondwanidium Gothan) del Carbónico y Pérmico gondwánico. Ameghiniana, 8 (3-4):189-227.

ARCHANGELSKY, S. \& AZCUY, C.L.1985. Carboniferous paleobotany and palynology in Argentina. Actas $X$ Int. Congr. Carb. Stratigr. Geol., Madrid, 1983, 4:267-280.

ARCHANGELSKY, S. \& GAMERO , J.C. 1979. Palinologia del Paleozóico Superior em el subsuelo de la Cuenca Chacoparanense, Republica Argentina. I. Estúdio sistemático de los palinomorfos de três perfaciones de la Província de Córdoba. Revista Espanñola de Micropaleontologia. Madrid, 11(3): 417-478.

ARCHANGELSKY, S. \& CÚNEO, R. 1981. Sobre La presencia del gênero Botrychiopsis Kurtz en la Formacion Nueva Lubeka, Permico inferior de Chubut, Argentina. Anais II Congresso Latino-Americano Paleontologia, Porto Alegre, Abril 1981 p.157-167.

ARCHANGELSKY, S. \& CÚNEO, R. 1991. The Neopaleozoic Floristic succession from Northwestern Argentina. A new perspective. Gondwana Seven Proceedings. Papers presented at the In: SEVENTH INTERNATIONAL GONDWANA SYMPOSIUM. São Paulo. Instituto de. Geociências, USP., 369-481.

ARCHANGELSKY, S.; AZCUY, C.L.; GONZÁLEZ, C.R. \& SABATTINI, N. 1987. Correlación general de biozonas. In "El sistema Carbonífero en la República Argentina” (Ed. $S$. Archangelsky), Acad. Nac. Ci., Córdoba, p. 281-291.

ARCHANGELSKY, S.; GONZÁLEZ, C.R.; CÚNEO, N.R.; SABATINI, N.; CÉSARI, S.N.; ACEÑOLAZA, F.G.; GARCIA, G.B.; BUATOIS, L.A.; OTTONE, E.; MAZZONI, A.F.; HÚNICKEN, M.A.; GUTIÉRREZ, P.R. (Eds.) 1996. El sistema Permico en La Republica Argentina y en la Republica Oriental del Uruguay. Acad. Nac. Ci. Córdoba.

ARTABE, A.; ARCHANGELSKY, S. \& ARRONDO, O.G. 1987. Sobre una frutificacion masculina asociada a frondes de Botrychiopsis Del Carbonifero de Cienaga Del Vallecito, 
Provincia de San Juan, Argentina. Actas VII Simposio Argentino de Paleobotánica y Palinologia (Buenos Aires), April 1987, p.21-24.

ASAMA, K. 1970. Evolution and classification of Sphenophyllales. Bull. Nat. Sci. Mus. Tokyo, 13(2): $291-316$.

AZCUY, C.L. 1991. Palinologia de la Formación Ambo (Carbonifero inferior), Perú. Ameghiniana 28(1/2):200.

AZCUY, C.L. \& SUAREZ-SORUCO, R. 1984. El género Nothorhacopteris en el Paleozoico superior de la peninsula de Copacabana. Bolivia. Abstracts Ann. Meet. W. G. Proy. IUGS 211:45-46.

AZCUY, C. L. \& DI PASQUO, M. 1999. Carbonifero y Pérmico de las Sierras Subandinas, Cordilheira Oriental Y Puna. In Geologia Argentina Anales 29. Buenos Aires, p.239-260.

AZCUY, C. L. \& DI PASQUO, M. 2000. Patynology of the Late Carboniferous from the Tarija Basin, Argentina: a systematic review of monosaccate pollen genera. Paleontographyca Abt.B 253:103-37.

BARBOSA, O. \& ALMEIDA, F.F.M. 1949. Nota sobre a estratigrafia da Série Tubarão em São Paulo. Anaia Academia brasileira. Ciências., Rio de Janeiro, 21(1):65-68.

BARBOSA, O. 1958. On the age of the Lower Gondwana floras in Brazil and abroad. In: INTERNATIONAL GEOLOGICAL CONGRESS, $20^{\circ}$, Mexico, 1956. Proceedings, p. 205236.

BERNARDES-DE-OLIVEIRA, M.E.C. 1977. Tafoflora Eogondvânica da camada Irapuá, Formação Rio Bonito (Grupo Tubarão), SC. São Paulo: inédito (Tese de Doutorado, Instituto de Geociências da USP), vol 1, 301p.

BERNARDES-de-OLIVEIRA, M.E.C. de \& PONTES, C.E. da SILVA. 1976. Algumas observações sobre Cordaitófitas da Formação Rio Bonito, Grupo Tubarão, Bacia do Paraná, Brasil. Tomo III do PREMER CONGRESO GEOLÓGICO CHILENO. Santiago, agosto de 1976.

BERNARDES-DE-OLIVEIRA, M.E.C. \& PONTES, C.E.S. 1977. Algumas observações sobre cordaitófitas de formação Rio Bonito, Grupo tubarão, bacia do Paraná, Brasil. Act. I Congres. Geol. Chileno, Santiago, 1976, III: L $21-L 81$.

BERNARDES-DE-OLIVEIRA, M.E.C.; ROHN, R.; SOUZA, P.A.; RICARDI-BRANCO, F.; RÖSLER, O.; IANNUZZI, R. \& ZAMPIROLLI, A.P. 1999. Revision of Upper Paleozoic Phytobiostratigraphy Schemes in the Northern Portion of Paraná Basin, Brasil. XIV INTERNAT. CONGR. CARBONIFEROUS-PERMIAN, Pander Society, Can. Paleontological Conferences, Programme Abstracts, Calgary, Aug./Sept./1999, p. 12. 
BERNARDES-DE-OLIVEIRA, M.E.C.; ROHN, R.; SOUZA, P.A.; ZAMPIROLLI, A.P.; RICARDIBRANCO, F.; IANNUZZI, LONGHIN, M.; LAGES, L.C. \& R. RÖSLER, O. 2001a. Late Carboniferous-Early Permian taphofloras from Northeastern Paraná Basin glacial succession in Brazil and comparasions to the Argentine record. In: Simpósio Argentino Paleozoico Superior, 2, Trelew, 2001 Resumenes..., Trelew, MEF. p.2.

BERNARDES-DE-OLIVEIRA, M.E.C.; RICARDI-BRANCO, F.; ROHN, R.; ZAMPIROLLI, A.P.; AMARAL, P.A do; LAGES, L.C. \& LONGHIM, M.E. 2001b.(no prelo). Sucessão Megafloristica do Carbonifero superior-permiano inferior (Grupo Tubarão), Bacia do Paraná, no Estado de Sâo Paulo.Resumos XVII CONGRESSO BRASILEIRO PALEONTOLOGIA, Rio Branco (Acre), 0/8/2001.

BOSS!, G.E. \& ANDREIS, R.R. 1985. Secuencias deltaicas y lacustres del Carbónico del centro-oeste argentino. Anal X Congr. Int. Estrat. Geol. Carb. Madrid, 285-309.

BOUREAU, E. 1964. Sphenophyta. In: Traité de Paléobotanique. Paris. Ed. Masson et cie. T. $3: 554$ p., 436 figs.

BOUREAU, E. 1971. Les Sphenophytes Biologie et Histoire Évolutive. Librairie Vvibert P.161.

BRONGNIAR, A. 1822. Sur la classification et la distribution des végétux fossiles en général, et sur ceux des terrains de sédiment supérieur en particulier. Mus. Hist. Nat. Paris Mém., 8:203-348.

CABRAL, JR., M. \& MOTTA, J.F.M. 1985. Geologia da Formação Itararé e sua potencialidade para carvão na região de Buri/ltapeva-SP. In: SIMPÓSIO REGIONAL GEOLOGIA, 5, São Paulo, 1985. Actas. SBG, 2:459-472.

CARRIZO, H.A. 1987. Las plantas fósiles de algunas formaciones neopaleozoicas relacionadas con niveles marinos en Precordillera $Y$ Cordillera frontal de San Juan $Y$ Mendoza. Seminario. U.N.T. San Miguel de Tucumán (inéd):1-135.

CARRIZO, H.A. 1990. Nuevos hallazgos de componentes de la flora NBG en Formación Cortaderas, Precordillera $Y$ en Formación Las Salinas, Patagonia Extraandina. Abstracts. Ann. Meet. W.G/Proy.211:93.

CAZZULO-KLEPZIG M.; GUERRA-SOMMER, M. \& ZIMERMANN, L. 1980.Considerações sobre um afloramento fossilifero do Grupo Itararé, Fazenda Goulart, Francisquinho, Município de São Jerônimo, RS. Boletim IG/USP, II: 85-97.

CAZZULO-KLEPZIG, M; GUERRA-SOMMER, M. \& MARQUES-TOIGO, M. 1980. Estudo macro e microflorístico do Grupo Itararé (Bacia do Paraná), Rio Grande do Sul. In:: XXX| 
CONGRESSO BRASILEIRO DE GEOLOGIA, Camboriú, 1980, Anais Academia brasileira Ciências, 5: 3027-3047.

CESARI, S.N.R. 1986. Megafloras de la Formación Tupe en Sierra de Maz Y Cénega del Vallecito, Cuenca Paganzo, Argentina. Anal Acad. Nac. Cs. Ex. Fis. Y Nat. 38:11-137.

CESARI, S.N.R. \& LIMARINO, C.O. 1987. Análisis estratigrafico del perfil de la Quebrada de la Cortadera (Carbonifero), Sierra de la Maz, La Rioja. Argentina. IV Congr. Latinoam. Paleont. Bolivia. 1:217-233.

CÉSARI, S.N.R. \& GARCIA, G.B. 1988. Alguns elementos de la Flora Tupense (Carbonifero) En la Cuenca San Rafael, Argentina. Ameghiniana 25(4):357-363, Buenos Aires, 1988.

CIANTELLI JR., C.A.; CABRAL JR., M. \& NAKANO, S. 1983. Avaliação preliminar das ocorrências de carvão mineral na região de Buri-Itapeva (SP). In:: SIMPÓSIO REGIONAL DE GEOLOGIA, São Paulo, 1983. Actas. SBG, 4:353-365.

CUERDA, A.J. \& FURQUE, G. 1981. Depósitos carbônicos de la Precodillera de San Juan. Parte 1-Comarca del Cerro la Chilca (Rio Francia)- Rev. Asoc. geol. argent.36(2):187-192.

CÚNEO, R. 1985. Hallazgo de uma flora Pre-Lubeckiana en la localidad de Arroyo Garrido, Chubut. Abstracts Ann. Meet. W. G, Proy. IUGS 211: $24-25$.

CÚNEO, R. 1986. Ecologia de las Floras Neopaleozoicas Argentinas. IV CONGR. ARGENTINO DE PALEONTOLOGÍA Y BIOESTRATIGRAFIA, 1986, Actas 1: 195- 204.

CÚNEO, R. 1990. La tafoflora de La Formacion Mojon de Hierro (Grupo Tepuel) En la localidade Arroyo Garrido, Paleozoico superior, Provincia de Chubut. Ameghiniana 27(44):225-238. Buenos Aires, 1990.

CÚNEO, R.; ARCHANGELSKY, S. \& WAGNER, R. H. 1993, Lower Permian Sphenophyllum from Chubut, Argentina: Ameghiniana, 30:225 - 243 .

DAEMON, R. F. \& QUADROS, L.P. 1970. Bioestratigrafia do Neopaleozóico da Bacia do Paraná. In:: Congresso Brasileiro de Geologia, 24, Brasilia, 1970. Anais... SBG, p. 359412.

DIAS, M.E.R.1993. Palinologia do Grupo Itararé no Rio Grande do Sul. Porto Alegre. inédito (Tese de Doutorado, Instituto de Geociências da UFRGS), 277p.

DOLIANITI, E. 1952. La flore fossile du Gondwana au Brésil, d'après sa position stratigraphique. In:: SYMPOSIUM SUR LES SERIES DE GONDWANA. CONGRES GEOLOGIQUE INTERNATIONAL, 190, Alger, 1952. Contributions reunis par Curt Teichert, p. 285-301.

DOLIANITI, E., 1953, Considerações sobre a presença de Gondwanidium plantianum no Rio Grande do Sul. - Anais Academia brasileira Ciências. 2 (25): 127 - 132, 1 lám. 
DOUBINGER, J. \& ALVAREZ RAMIS, C. 1980. Notas sobre la Flora de la Formacion Ambo,

Carbonifero inferior del Perú. Actas // Congr. Argent. Paleont. Y Bioestrat. Y / Congr. Latinoam. Paleont. Buenos Aires (1978). 4:89-102.

FEISTMANTEL, C.B. 1879. Paleozoische und Mesozoische Flora des ostlichen Australiens. Palaeontographica, suppl. 3 (Nachtrag): 133-195.

FONTQUER, P. 1985. Diccionario de Botánica. Editorial Labor, p. 26.

FREGUELLLI, J. 1943. Acerca de lapresencia de Rhacopteris ovata en el Paganzo I de Villa Unión, La Rioja-Rev. Mus. La Plata S. Geol. 2(12):11-47.

GASTALDO, R.A. \& BOERSMA, M.1983. A reinvestigation of early Pensylvanian species of Mariopteris from the Appalachian Region II. Eusphenpteris and Sphenopteris. Review of Paleobotany and Palinology, 38(1982/1983):227-247.

GEINITS, H.B. 1876. Uber Rhatische Pflanzen und Thierreste in den argentinischen Provinzen

La Rioja, San Juan und Mendoza. Palaeontographyca, Suppl., 3(2):1-14.

GEINITZ, H.B. 1862. Dijas und die zechstein Formation und das Rothliegends. 2, p.150, 1862.

GOEPPERT, H.R. 1964. Die fossile flora der Permischen Formation. Palaeontographica, 12:1 224 , est. $1-40,1864$.

GOLONKA, J.; ROSS, M.I. \& SCOTESE. C. R. 1994. Phanerozoic Paleogeographic and Paleoclimatic Modeling MASPS. Pangea: Global Environment and Resourcer Canadian Society of Petroleum Geologists, Memoir 17:18-19.

GONZALEZ, C.R. \& BOSSI, G.E. 1986. Los depósitos carbonicos del oeste de Jaguel, La Rioja. Actas IV. CONGR. ARG. PALEONT. Y BIEST. 1:231-236.

GOTHAN, W., 1927. Gondwanapflanzen aud der Sierra de los Llanos und benachbarten Gebieten. - Abh. Senck. Nat. Ges., 31: $341-344$.

GUTIERREZ, P.R. 1984.Formación Cerro Agua Negra: Consideraciones sobre su paleoambiente sedimentario $Y$ contenido paleontológico. San Juan. Argentina. Abstracts. Ann. Meet.W.G.Proy. IUGS 211:31-32.I

GRAND'EURY, C. 1877. flone Canbonif. Du Departament de la Loire et de Centre de la France-Mém. Acad. Sc.Ranis, 24: 624.

GUERRA-SOMMER, M. \& CAZZULO-KLEPZIG, M. 1981. A tafoflora do Grupo Itararé no Rio Grande do Sul sua importância bioestratigráfica no Gondwana Sul-Brasileiro. In: II CONGRESSO LATINO-AMERICANO PALEONTOLOGIA, Porto Alegre, Anais.l: 127-140. GUERRA-SOMMER, M. 1989. Megafloras ocorrente em horizontes associados a carvões no Rio Grande do Sul. Acta Geologica Leopoldensia 29(7):93-122. 
GUY-OHLSON, D. 1992. Botryococcus as an aid in the interpretation of palaeoenvironment and depositional processes. Review of Palaeobotany and Palynology, 71: $1-15$.

IANNUZZI, R. \& RÖSLER, O. 2000. Floristic migracion in South America during the Carboniferous: phytogeographic and bioestratigraphic implications. Palaeogeography, Palaeoclimatology, Palaeocology, 161:71-94.

JONES, M.J. \& TRUSWELL, E.M. 1992. Late Carboniferous and Early Permian palynostratigraphy of the Joe Joe Group, southern Galilee Basin, Queensland, and implications for Gondwanan stratigraphy. BMR Journal of Australian Geology \& Geophysiscs, 13:143-85.

KURTZ, F. 1921. Atlas de plantas fósiles de la República Argentina. Actas Acad. Nac. Cienc. Córdoba, 7:125-139 (27 pls.).

KURTZ, F., 1895. Contribuciones la Palaeophytologia Argentina. I. Botrychiopsis, un género nuevo de las Cardiopterídeas. - Rev. Mus. La Plata, 6: 119-124, llám.

LIMA, M.R. de; DINO, R. \& YOKOYA, N.S. (1983). Palinogia de concreções calcifereas do Subgrupo ttararé (Neopaleozóico da Bacia do Paraná) na região de Araçoiaba da Serra, Estado de São Paulo. Anais Academia brasileira Ciências, 55(2): 195 - 208.

MAITHY, P.K. 1965. Studies in the Glossopteris flora os India. 20-Noeggerathiopsis and Allied Remainins from the Karharbari Beds, Giridih Coal Field, India. The Palaeobotanist, 13(1):94-100. Luckonow, 1964.

MARESHWARI, H. K. 1968. Studies in the Glossoptenis Flora of India 38. Remarks on Tryzygia speciosa noyle with reference to the Genus Sphenophyllum Koenig. The Palaeobotanis 16 (1): $283-287$.

MARQUES-TOIGO, M. 1988. Palinologia, bioestrigrafia e paleoecologia do Neopaleozóico da Bacia do Paraná nos estados do Rio Grande do Sul e Santa Catariana, Brasil. Porto Alegre. inédito (Tese de Doutorado, Instituto de Geociências da UFRGS), $259 \mathrm{p}$.

MARQUES-TOIGO, M. 1991. Palynobiostrtigraphy of the Southern Brazilian Neopaleozoic Gondwana sequence. In:: INTERNACIONAL GONDWANA SYMPOSIUM, $7^{\text {st }}$, São Paulo, 1988. Proceedings..., p.503 - 15.

MCCOY, F. 1847. On the fossil botany and zoology and zoology of the rocks associated with the coal of Australia. Ann. Mag. Nat. Hist., 20 (132):145-157 (pls. IX-XI).

MCLOUGHLIN, S. 1992. Permian Sphenophytes from the Collie and Perth Basins, Western Australia. Review of Palaeobatany and Palynology 75: 153- 182. 
MECLONGHLIN, S. \& DRINNAN. 1996. Anatomically preserved Permian Noeggerathiopsis leaves from east Antarctica. Review of Palaeobotany and Palynology p.87-90.

MENÉNDEZ, C.A. 1965. Contenido palinológico en sendimentos com "Rhacopteris ovata" (Mc Coy) Walk. de La Sierra de Famatina, La Rioja. Revista del Museo Argentino de Ciencias Naturales "Bernardino Rivadávia", 1(3):45 - 80.

MESIGOS, M.G. 1953. El Paleozoico superior de Barreal y su continuación austral. Sierra de Barreal (Provincia de San Juan). Rev. Asoc. Geol. argent. 8 (2):65-109.

MEYEN, S. 1967. New data on relationship betwween Angara and gondwana Late Paleozoic Flora-IUGS, Gondwana Strat, Symp.:141-54, 1 est., 11 text-fig., B.Aires.

MEYEN, S. 1971. Phyllotheca-like Pants from the Upper Palaeozoic flora of Angaraland. Palaeontographica. Abt B Stuttgart 133: 1-33, pl. 1-12,

MEYEN, S.V. 1987. Fundamentals of Paleobotany. London, Chapman \& Hall. 432p.

MILLAN, J.H. 1972. Macroflórula Carbonifera de Monte Mor, Estado de São Paulo. Tese de Doutorado, Instituto de Geociências., Univ. São Paulo, 165pp., 12 est.

MLLLAN, J. H. 1975. Tafoflórula Monte Mor do Estado de São Paulo. Seus elementos e seu significado no Gondwana Inferior do Brasil. Revista Brasileira de Geociências. São Paulo, $5(1): 1-14$

MLLLAN, J.H. 1977. Moldes Medulares da Tafoflórula Gondwânica de Monte Mor, Estado de São Paulo. Anais Academia brasileira Ciências, Rio de Janeiro, 49 (1): 195-204

MILLAN, J.H. 1979. Rhacopteris e Botrychiopsis no Eogondwana de Monte Mor, Subgrupo Itararé do Estado de São Paulo- Anais Academia brasileira de Ciências, Rio de Janeiro 51(1):109-120.

MILLAN, J.H. 1981. Sobre a presença de Sphenophyllales no Eogondwana de Monte Mor, Subgrupo ltararé do Estado de São Paulo. In:: CONGRESSO LATINO-AMERICANO DE PALEONTOLOGIA, 20, Porto Alegre, 1981. Anais... UFRGS, v. 1, p. 113-126.

MILLAN, J.H. 1987a. Os pisos florísticos do carvão do Subgrupo Itararé no Estado de São Paulo e suas implicações. In: CONGRESSO BRASILEIRO DE PALEONTOLOGIA, $10^{\circ}$, Rio de Janeiro, 1987. Anais... SBP, p. 832-857.

MILLAN, J.H. 1987b. Descoberta de Frondes de Botrychiopsis plantiana no Eogondwana do Município de ltapeva, Subgrupo Itararé do Estado de São Paulo. Anais X CONG. BRAS. PALEONT. Rio de Janeiro, 2: 809-829.

MILLAN, J.H. 1989. Sobre as Sphenopsida da tafoflórula do Eogondwana do Municipio de Itapeva, carvão do Subgrupo Itararé do estado de São Paulo. Anais Academia brasileira Ciências, Rio de Janeiro, 61 (4):479. 
MILLAN, J.H. 1991a. Novas ocorrências de sementes platispérmicas nos municipios de Itapeva, SP, e Cerquilho, SP, em Tafofloras do Grupo Tubarão, Eogondwana da Bacia do Paraná. Anais Academia brasileira Ciências, Rio de Janeiro, 63(1): 96.

MILLAN, J.H., 1991b. Sobre as Shenopsidas de tafoflora associada a camadas carbonosas do Subgrupo Itararé, Eogondwana da Bacia do Paraná, no municipio de Itapeva, SP, Brasil. Anais Academia brasileira Ciências, Rio de Janeiro, 63(3): 229-245.

MILLAN, J.H., 1993. Sobre as cordaitales da Tafoflora Eogondwânica de Itapeva, SP, Subgrupo Itararé da Bacia do Paraná, Brasil. An. Acad. bras. Ci., Rio de Janeiro, 65(2): 213.

MILLAN, J.H., 1995a. Ocorrência de Notorhacopteris na Tafoflora de ltapeva, SP, Subgrupo Itararé da Bacia do Paraná, Brasil. An. Acad. bras. Ci., Rio de Janeiro, 67(3): 384.

MILLAN, J.H., 1995b. Novas ocorrências de sementes platispérmicas em Tafofloras associadas à camada carbonosas do Grupo Tubarão, Eogondwana da Bacia do Paraná, no Estado de São Paulo. An. Acad. bras. Ci., Rio de Janeiro, 67 (1): 117-128, 1 estampa.

MILLAN, J.H., ANDRADE, A. B. \& DOLIANITI, E. 1982. Uma nova tafoflórula do Eogondwana de Itapeva, SP. Anais Academia brasileira Ciências, Rio de Janeiro, 54 (4): 753.

MOORE, P. D. \& WEBB, J. A. 1978. An illustraded guide to pollen analysis. Londres, 133 p., Hodder and Stoughton, Richand Clay Ltda.

MORAES-REGO, L.F. de. 1934. A hulha em São Paulo. Inst. Eng. São Paulo, 20(109):345352, São Paulo.

MORELLLI, S.; LIMARINO, C.; CÉSARI, S. \& AZCUY, C. 1984. Características litoestratigráficas y paleontológicas de la Formacion Lagares en los alredores de la Formación Lagares en los aredores de la mina Margarita, provincia de La Rioja. Actas $I X$ Congr. geol. argent. Bariloche 4:337-347.

NORIEGA, B.N. 1987. Contribuición al conocimiento geológico de sector situado al sur del arroyo Agua de Las Cabeceres. Precordillera de San Juan. Seminario U.N.T. (inéd.):1-118.

OTTONE, E.G. 1987. Plantas fósiles de La Formación Santa Máxima (Carbonífero), Província de Mendoza, República Argentina-Ameghiniana 24(1 2):115-128.

OTTONE, E.G. 7 AZCUY, C.L. 1986. El perfil de La Quebrada la Delfina, provincia San Juan. Revista de La Asociación Geológica Argentina, XLI (1-2):124-36.

PASQUALINI, M.; CUNHA, A.S.; GUERRA-SOMMER, M. \& PICCOLI, A.E.M. 1986. Análise paleoecológica de sequências paleoflorísticas na área de Mariana pimentel Guaiba, RS. Anais do XXX CONGRESSO BRASILEIRO DE GEOLOGIA, Goiânia, Goiás, 1986, 5(1):556-569. 
PARRISH, J.T. 1990. Gondwana Paleogeography and Paleoclimatology. In: TAYLOR, T.N.

\& TAYLOR, E.L. Editors., Antartic Paleobiology. Springer-Verlag, p. 15-26.

PERINOTTO, J.A. \& RÖSLER, O. 1987. Raizes fósseis na lapa do carvão de Bairro Aliança (Cerquilho-SP) e Mato Seco (Cesário Lange-SP). In: CONGRESSO BRASILEIRO DE PALEONTOLOGIA, $10^{\circ}$ Rio de Janeiro 1987 Resumos das Comunicações R.J.SBP, p.21.

PETRI, S. \& SOUZA, P.A. 1993. Sintese dos conhecimentos e nova concepção sobre a bioestratigrafia do Subgrupo Itararé, Bacia do Paraná, Brasit, Revista /G. 14 (1): 7-18.

PLANT, N. 1869. The Brazilian Coal Fields. Geological Magazine, 6(4):1-10, com apêndice Coal Plants from Brazil, por Carruthers, W. Londres, 1869.

POTONIE, R. 1970. Synopsis der Gattungen der Sporae Dispersae. V Teil: Nachträge zur allen Gruppen (turmae). Geologischen Jahrbuch, 69:111-94.

QUADROS, L.P. de. \& MELO. J.H.G. 1987. Método prático de preparação palinológica em sedimentos pré-mesozóicos. Boletim de Geociências da Petrobrás, 1(2):205 - 14.

RADCZENKO, G.P. - 1955 - Atlas des formes directrices de la faune et de la flore des depôts du Permien Du Bassin De Lusnetsk. V.S.Gg.E., 1955.

RAVEN, P. H.; EVERT, R. F. \& EICHHORN, S. E. 1996. Biologia Vegetal. Quinta Edição. Guanabana Koogan 728 .

READ, C.B. 1941. Plantas fósseis do Neopaleozóico do Paraná e Santa Catarina, Brasil.

Dep. Nac. Prod. Miner., Div. Geol. Min, Monografia 12,102p., 8 est., 1 mapa e 1 perfil geológico. Rio de Janeiro, 1941.

RETALLACK, G. 1980. Late Carboniferous to Middle Triassic megafossil floras from the Sidney basin. In: C. Herbert \& R. Helby (Eds.): A guide to the Sydney Basin. Geol. Surv. N.S. Wales Bull., 26: 384-430.

RETALLACK, G. J. 1999. Carbonifenous Fossil Plants and solils of an Early tundra Ecosysten. Palaios 5(4):324-336.

RIGBY, J. F. 1966 a. The Lower Gondwana Floras of the Perth and Collie Basins, Western Austrália. Palaeontogr, AbtB, 118 (4-6):123-126, pls. 32 e 33.

RIGBY, J. F. 1966 b. Some Lower Gondwana Articulates from New South Wales. In: Symp. on Floristics and Stratigraphy of the Gondwanaland. p. 54 plate 1.

RIGBY, J.F. 1969. Permian Sphenopsida from Antarctica. Contributions to Paleontology.

Descriptions and Distribution of Species of the fossil Pants Genera Phyllotheca,

Schizoneura, Paracalamites and Umbellapjyllites. Geol. Surv. Profes. Paper 613-f:1-13, figs. 3 pls. 2 tabls.. Washington, 1969. 
RIGBY, J. F. 1970. The distribuition of Lower Gondwana Plants in the Parana Basin of Brazil and Gondwana. Symp., Pretoria, Proc. and Pap., p. $575-584$..

RIGBY, J. 1971. Some Palaebotanical observations concerning the bowen Basin. Proceedings of the second Bowen Basin Symposium (A. Davis Ed). Geol. Survey.of. Quensland Report Brisbane, 62:21-29. 1971.

RIGBY, J. F. 1972. The Notocalamitaceae, a New Family of upper Paleozoic Equisetaleans. The Palaeobotanist, 19(2):161-163, est..1figs de texto Lucknow, 1970.

RIGBY, J.F. 1973. Gondwanidium and other similar Upper Paleozoic genera, and their stratigraphic significance. Geol. Surv. Q/d. Publ., 350 Paleontol. Pap., 24:1-10 (3pls.).

RIGBY, T. F. 1985. Aspects of Carboniferous Palaeobotany in Eastern Australia. Divième Congrés International de Stratigraphie et de Géologie du Carbonifere Madrid, 1983. Compte Rendu, 4:307-312.

RIGBY, J.F. 1989. Bergiopteris and Botrychiopsis from the late Paleozoic of Gondwanaland. XI e Congres Internacional de Stratigraphie et de Geologie du Carbonifere Beijing 1987, Compte Rendu 3:143-148.

RIGBY, J. 1993. Paleontology of the Permian of Western Australia. In: Swarko. Geological Survey of Western Australia 136:1-417.10 microfiche test, 2 microfiche tables.

ROCHA-CAMPOS, A.C. \& ARCHANGELSKY, S.S/a. Bioestratigraphy and Correlation. In: The Carboniferous of the word II. Austratia, Indian Subcontinent, South Africa, South America, \& Noth Africa .IUGS Publication 20-226-297.

ROCHA-CAMPOS, A.C. \& RÖSLER, O. 1978. Late Paleozoic faunal and floral sucessions in the Paraná basin, Southeastern Brazil. Boletim IG-USP, São Paulo, 9:1-15.

RÖSLER, O. 1974. Novas espécies de Sphenophyta na Formação Rio Bonito (Permiano) no Estado do Paraná. Boletim IG-USP, 5:17-28.

RHON, R.; LONGHIM, M.E.; BERNARDES-DE-OLIVEIRA, M.E.C. \& NAVARRO, G.R.B. 2000. Nova ocorr6encia fitoffossilífera neocarbonifera eopermiana do Subgrupo ltararé, à margem esquerda do rio Capivari, Municipio de tiête-SP, Brasil. Revista Universidade de Guaruhos V (n'especial):57-61.

RÖSLER, O. 1978. The Brazilian eogondwanic floral successions. Boletim IG-USP, Săo Paulo, 9: 85-91.

RÖSLER, O. \& ROHN, R., 1984. Sphenophyllum paranaesis n. sp. da Formação Rio do Rasto (Permiano Superior) de Dorizon, Estado do Paraná. Boletim IG-USP, 15:9-104. 
SAAD, A.R. 1977. Estratigrafia do Subgrupo Itararé no centro e sul do Estado de São Paulo. São Paulo, 107 p, inédito (Dissertação de Mestrado - Instituto de Geociências da USP).

SCALABRINI, J. 1973. El Carbónico de La Precordillera argentina al norte del río Jáchal- Actas $\checkmark$ Congr. geol. argent., Bs.As. 3:387 401 .

SCOTESSE, C. R.; BONCOT, A. J. \& MCKERROW, N.S. 1999. Gondwana palaeogeognaphy and palaeolimatology. Journal of African Earth Sciences. 28(1):99-14.

SEWARD, A. C., 1898. Fossil plants. v. I. Cambridge Univ. Press, Cambridge, 452 pp.

SEWARD, A. C., 1903. Fossil Flora of Cape Colony. Ann. South Afri. Mus., 4: 1-122, 14 Láms.

SEWARD, A.C. 1917. Fossil Pants 3. Cambridge Biol. Ser., 337 pp.. London, 1917.

SILVA, E.L. DA, 1994. Análise estratigráfica do Subgrupo Itararé (PC) na região de BuriItapeva (SP). (Inédito), Dissertação de Mestrado - Unesp, Rio Claro, $p$.

SOUZA, P.A. de. 1996. Palinologia e bioestratigrafia do Subgrupo Itararé em Araçoiaba da Serra (Westphaliano, Bacia do Paraná), Estado de São Paulo, Brasil. São Paulo: inédito (Dissertação de Mestrado, Instituto de Geociências da USP), 192p.

SOUZA, P.A. de 1997. Dados palinológicos do Carbonífero da Bacia do Paraná no Brasil, Revista Universidade Guarulhos, Geociências, III (Número Especial):43 - 8.

SOUZA, P.A. DE 1998. Palaeoenvironmental considerations about the Itarare Subgroup at Araçoiaba da Serra, State of São Paulo Basin), Brazil. Ameghiniana, 35(3):315- 20.

SOUZA, P.A. de. 2000. Palinobioestratigrafia do Subgrupo Itararé Carbonífero/Permiano, na Porção Nordeste da Bacia do Paraná (SP/PR, Brasil). São Paulo: inédito (Tese de Doutorado, Instituto de Geociências da USP), 192p.

SOUZA, P.A. de; LIMA, M.R. de \& SAAD, A.R. 1990. Palinologia dos carvões paleozóicos do Estado de São Paulo. I - O Carvão de Buri. Paleobotânica Latinoamericana, Circular Informativa da ALPP, 9(1):55.

SOUZA, P.A. de; LIMA M.R. de \& SAAD, A.R.1993a Palinologia dos carvões paleozóicos do Estado de São Paulo. Brasil. 1 - O Carvão de Buri. Revista do Instituto Geológico, 14(1):5 20.

SOUZA, P.A. de; LIMA, M.R. de \& SAAD, A.R. 1993b. Palinologia dos carvões paleozóicos do Estado de São Paulo. Brasillll - O Carvão de Monte Mor. Anais da Academia Brasileira de Ciências, 65(3):327.

SOUZA, P.A. de; LIMA, M.R. de \& SAAD, A.R. 1993c. Palinologia dos carvões paleozóicos do Estado de São Paulo. Brasil. III - O Carvão de Cerquilho. In:: CONGRESSO BRASILEIRO DE PALEONTOLOGIA, 13, São Leopoldo, 1993. Resumos...SBP, p.62. 
SOUZA, P.A. de; DINO, R. \& PETRI, S. 1996. Palinoestratigrafia do Subgrupo Itararé em Araçoiaba da Serra (SP), Westphaliano da Bacia do Paraná, In:: CONGRESSO BRASILEIRO DE GEOLOGIA, XXXIX, Salvador, 1996. Anais... SBG, 2:287 - 9.

SOUZA, P.A.; LIMA, M.R. \& SAAD, A.R. 1997. Palinologia dos carvöes paleozóicos do Estado de São Paulo. I- O carvão de Monte Mor. Revista do Instituto Geológico, 18 (1/2): 7-21.

SOUZA, P.A. de \& PETRI, S. 1998. Reworked palynomorphs in the Upper Carboniferous sediments at Araçoiaba da Serra (Itararé Subgroup, Paraná Basin), State of São Paulo, Brazil. Ameghiniana, 35(4):379-85.

SOUZA, P.A. de; VESELY, F.F. \& ASSINE, M.L. 1999. Contribuição palinológica ao conhecimento do subgrupo ltararé na Serra dos Paes, sul do Estado de São Paulo. Revista do Instituto Geológico, (no prelo).

SOUZA, P.A. de; BATEZELLI, C.V.B.; DI PASQUO, M.; AZCUY, C.L.; SAAD, A.R. \& PERINOTTO, J.A.J. 2000. Ocorrência de palinomorfos do Subgrupo Itararé (C/P da Bacia do Paraná) em Jundiaí (SP, Brasil). Revista Universidade Guarulhos, Geociéncias (no prelo).

SRIVASTAVA, A. K. \& RIGBY, J. F. 1983. Sphenophyllum, Trizygia and Gondwanophyton from Barakar Formation of Raniganj Coal Field, with a revision of Lower Gondwana Sphenoplyllales. Geoplytology, 13(1): 55-62, 1983.

STWART, W. N. 1981, the Progymnospermopsida the construction of a concept. Candian Journal of Botany 159: 1539 - 42.

STWART, W. N. \& ROTHWELL, G.W. 1993. Paleobotany and the evolution of plants. $2^{a}$.Ed. Cambridge University Press. 521p.

SUNDARAM, D. 1980. Observações palinológicas sobre alguns sedimentos do Gondwana inferior da Bacia do Paraná, Brasil. Boletim IG --USP, 11:161 - 89.

SUNDARAM, D. 1987. Palinologia do Subgrupo Itararé (Neopaleozóico da Bacia do Paraná) no Estado de São Paulo, Brasil. São Paulo, 311 p., 10 est., inédito (Tese de Doutorado - Instituto de Geociências da USP).

SURANGE, K. R., 1966. Indian Fossil Pteridophytes. - Bot. Ind., 4, VIII: 1 - 209.

TAYLOR, T.N. 1981. Paleobotany: na introdution to fossil plant biology New York, McGrawHill. 589p.

WALKON, A.B. 1934. Notes on some Carboniferous plants from New South Wales. Proc. Linn. Soc. N.S.W., 59(5-6):430-434.

WHITE, M. E. 1990. The flowering of Gondwana. Princeton University Press Princeton, New Jersey p. $87-90$. 
ZAMPIROLLI, A.P. \& BERNARDES-DE-OLIVEIRA, M.E.C.1999a, Ocorrência de cf. Koretrophyllites, sp., na tafoflora do Eogondvana no Municipio de Itapeva, SP. REUNIÃO ANUAL DA SOCIEDADE BRASILEIRA DE PALEONTOLOGIA, PALEO 99. Univ. Guarulhos, p. 12.

ZAMPIROLLI, A.P. \& BERNARDES-DE-OLIVEIRA, M.E.C. 1999b (no prelo), O gênero Paracalamites Zallesky, na tafoflora Neocarbonifera de Itapeva (SP), Subgrupo Itararé, Bacia do Paraná, Brasil. Revista do Instituto Geológico- SEMA.

ZAMPIROLLI, A.P.; SOUZA, P.A.; \& BERNARDES-DE-OLIVEIRA, M.E.C.1999a (no prelo). Ocorrência de esfenófita equisetaleana cf. Koretrophyllites, sp., na tafoflora neocarbonífera do Subgrupo Itararé, Bacia do Paraná, no Municipio de Itapeva, SP. Revista Universidade de Guarulhos-Gociências, Ano IV (6) 1999 p.96-101.

ZAMPIROLLI, A.P.; BERNARDES-DE-OLIVEIRA, M.E.C.; \& SOUZA, P.A. 1999b. Levantamento da composição e sucessão paleoflorísticas do Neocarbonifero-Eopermiano (Grupo Tubarão) no Estado de São Paulo. ll-1. Considerações sobre a tafoflora de préglossopterideas de Itapeva, Subgrupo itararé, Bacia do Paraná, Brasil. XVI CONGRESSO BRASILEIRO DE PALEONTOLOGIA CRATO. CE., agosto, 1999, Resumos p. 127.

ZAMPIROLLI, A.P. \& BERNARDES-DE-OLIVEIRA, M.E.C. 2000. O gênero Paracalamites Zallesky, na tafoflora Neocarbonífera de Itapeva (SP), Subgrupo Itararé, Bacia do Paraná, Brasil. Revista de Guarulhos -Geociências, V (nº especial):248.

ZAMPIROLLI, A.P.; SOUZA, P.A. \& BERNARDES-DE-OLIVEIRA, M.E.C. 2000..Assembléia Palinológica Neocarbonífera da Tafoflora de ltapeva (SP), Subgrupo Itararé, Bacia do Paraná, Brasil. Revista de Guarulhos -Geociências, V (nº especial):247. 
ESTAMPAS 


\section{Estampa 1}

Fig.1- Sphenophyllum sp. Impressão foliar de grande tamanho. Espécime MN/UFRJ-1961PbA.

Fig.2- Sphenophyllum sp. Contra-impressão do espécime anterior. Espécime MN/UFRJ-1961PbB.

Fig.3- S. cf. S. rhodesii Rigby 1966 Contra-impressão de fragmento verticilar com dois ou até três foliolos de diferentes tamanhos. Espécimes GP/3E8912D'e D".

Fig.4- S. cf. S. rhodesii Rigby 1966 Impressão foliar diminuta com o lado direito incompleto. Espécime GP/3E-8912.

Fig.5- S. cf. S. rhodesii Rigby 1966 Impressão foliar tipicamente cuneiforme e com venação reta, dicotômica e aberta. Espécime MN/UFRJ-1963PbA.

Fig.6- S. cf. S. rhodesii Rigby 1966 Contra-impressão do espécime anterior com uma outra folha destacada na porção inferior. Espécime Mn/UFRJ$1963 \mathrm{PbB}$.

Fig.7- S. cf. S. churulianum Srivastava \& Rigby 1983 Impressão foliar grande, fragmentada, com venação encurvada para as margens laterais. Espécime MN/UFRJ-1962Pb. 


\section{Estampa 1}
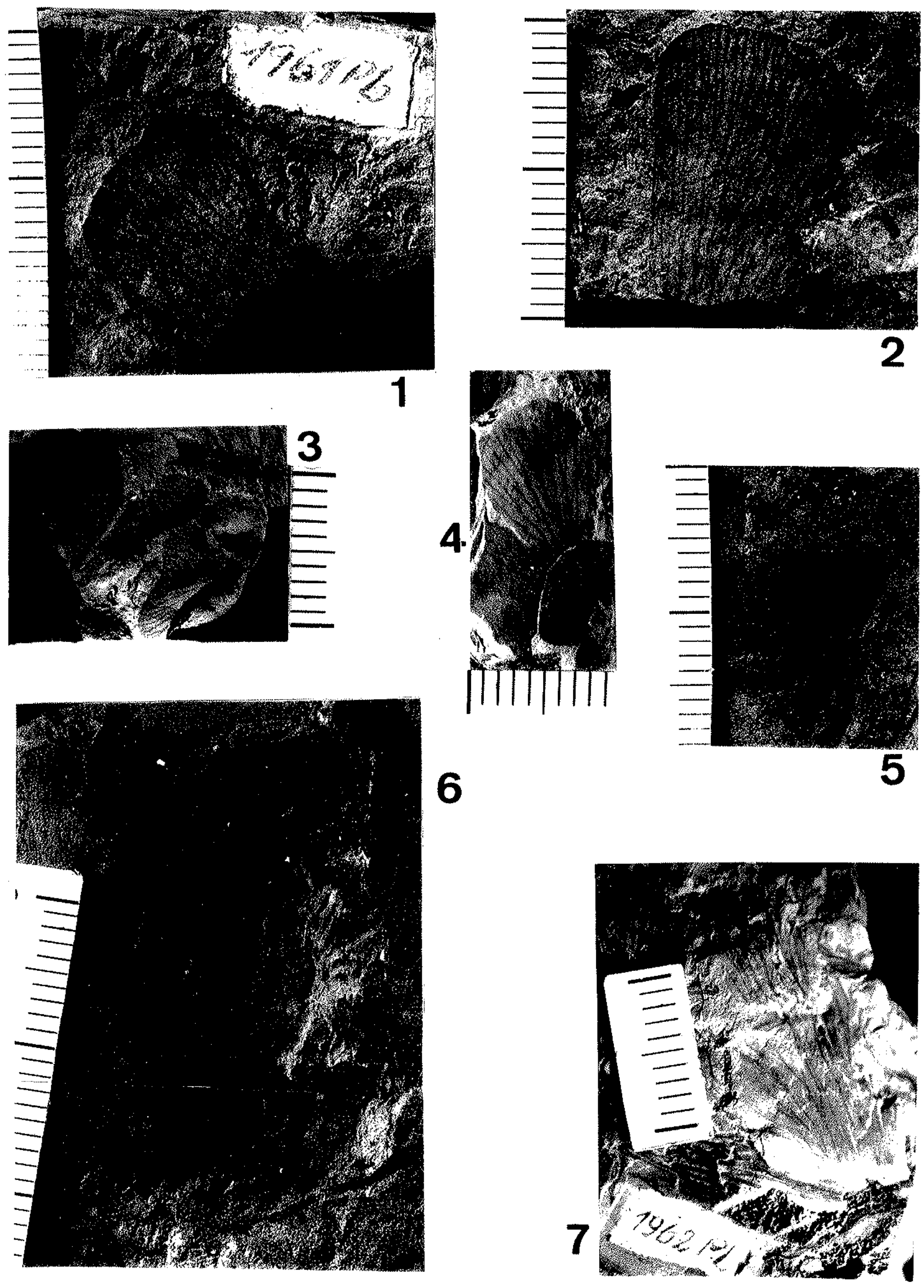


\section{Estampa 2}

Fig. 1- cf. Koretrophyllites sp. - Impressão caulinar articulada, fragmentada, apresentando dois ou três verticilos foliares. Espécime GP/3T-2266.

Fig.2- Paracalamites levis Rigby 1966 nov. emend.- Impressão de fragmento caulinar articulado com uma proporção média de largura/comprimento de 1:0,57-1:0,91. Espécime GP/3E-2266

Fig.3 Paracalamites australis Rigby 1969 nov. emend.- Impressão de fragmento caulinar articulado com uma proporção média de largura/comprimento de 1:3,33. Espécime MN/UFRJ-1970Pb.

Fig.4- Paracalamites montemorensis Millan 1977 nov. emend. - Impressão de fragmento caulinar articulado com uma proporção média de largura/comprimento de 1:1-1:1,99. Espécime GP/3E-2264.

Fig.5- Paracalamites levis Rigby 1966 nov. emend.- Impressão de fragmento caulinar articulado com uma proporção média de largura/comprimento de 1:0,57-1:0,91. Espécime GP/3E-2267. 


\section{Estampa 2}

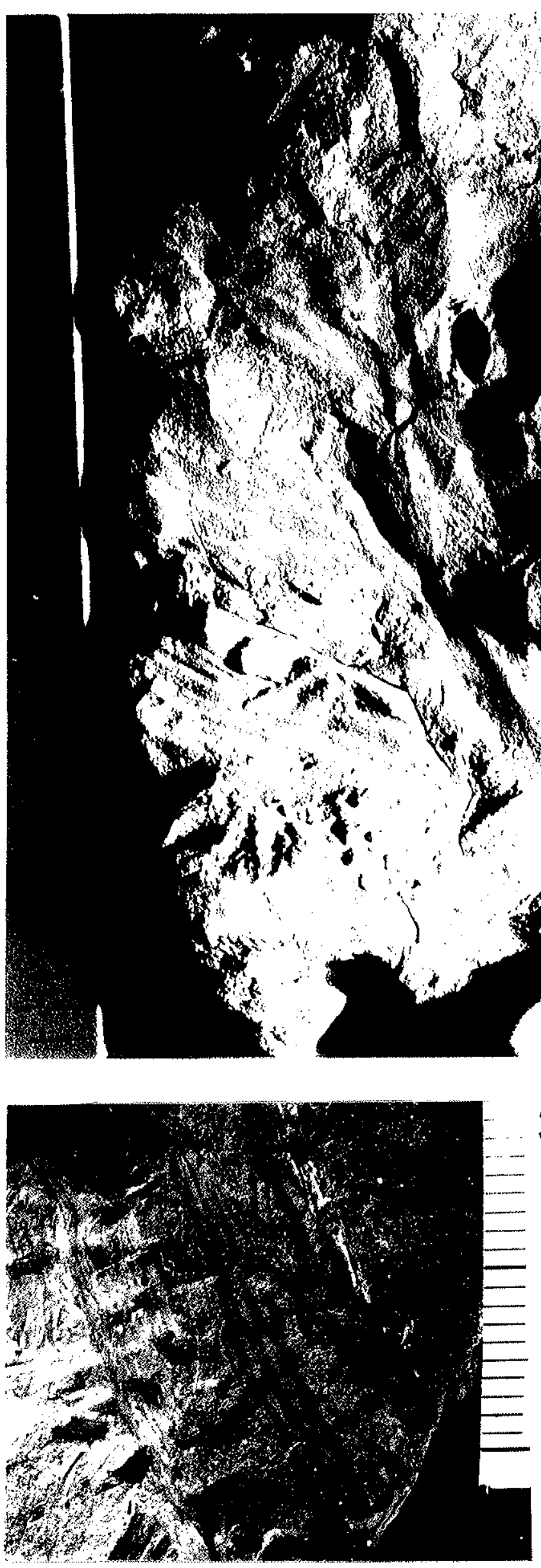

wor. $3 x+3$
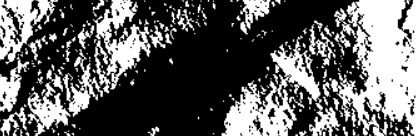

ing

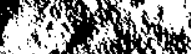

Mrox

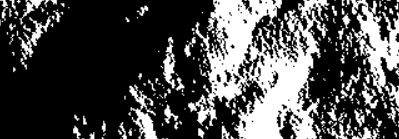
Hown ofos

Now s.

is in ondy Worations

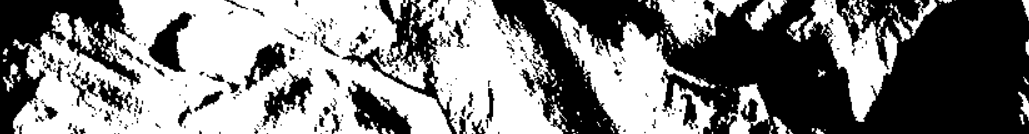

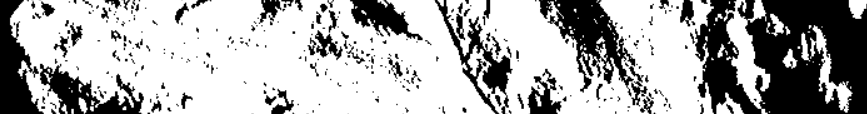

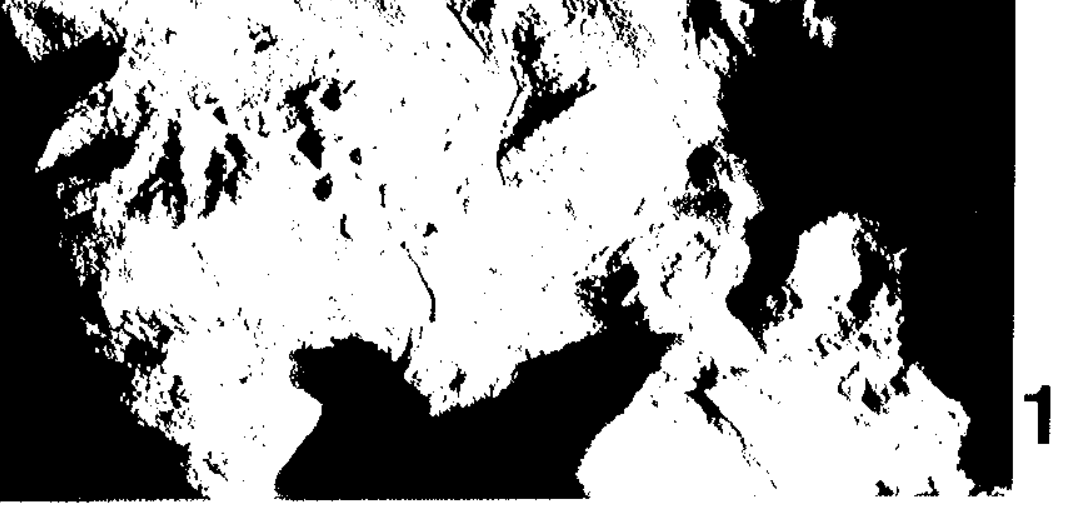

3

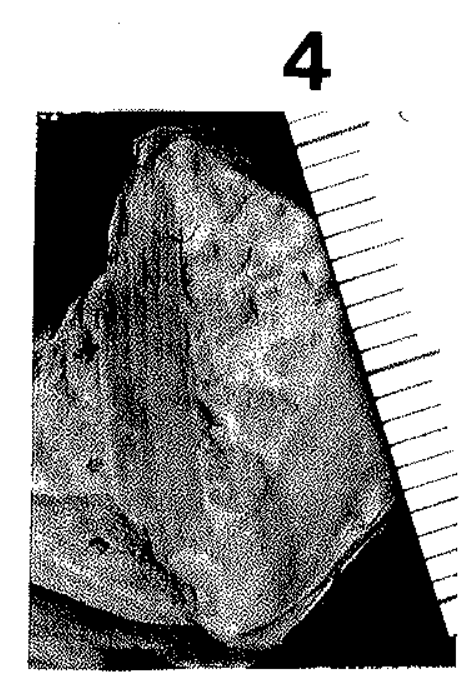

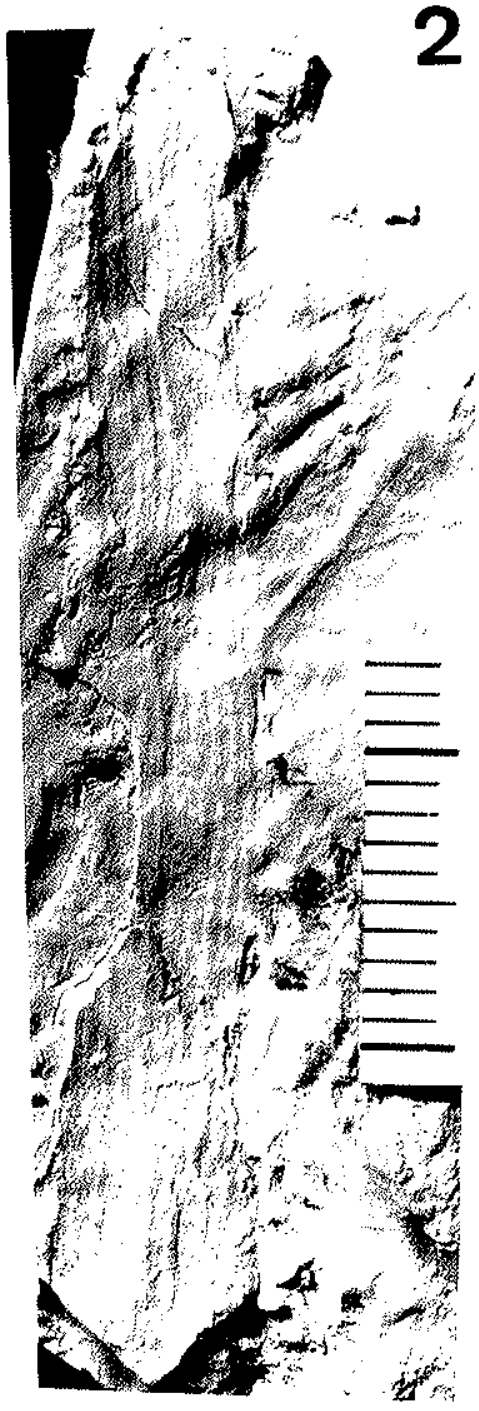

5

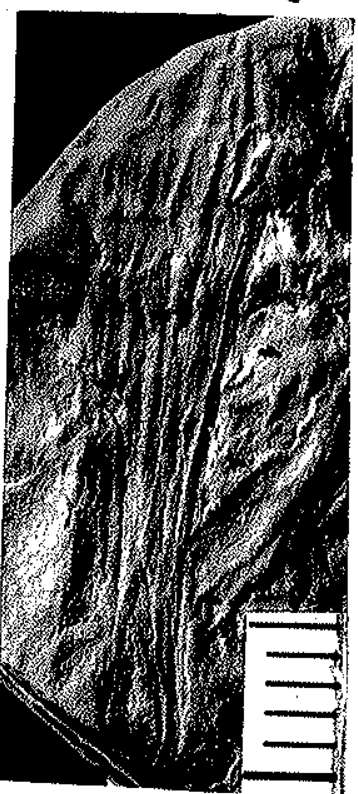




\section{Estampa 3}

Fig. 1- Paracalamites levis Rigby 1966 nov. emend - Impressão de fragmento caulinar articulado com uma proporção média de largura/comprimento de 1:0,57-1:0,91. Espécime MN/UFRJ-1981PbA.

Fig.2- Paracalamites montemorensis Millan 1977 nov. emend - Impressão de fragmento caulinar articulado com uma proporção média de largura/comprimento de 1:1-1:1,99. Espécime MN/UFRJ-1991PbA

Fig.3- Paracalamites levis Rigby 1966 nov. emend - Impressão de fragmento caulinar articulado com uma proporção média de largura/comprimento de 1:1-1:1,99. Espécime MN/UFRJ-1989Pb.

Fig.4- Paracalamites sp. - Molde externo de fragmento caulinar articulado, apresentando apenas um nó. Espécime GP/3E-2265.

Fig.5- Paracalamites australis Rigby 1969 nov. emend - Impressão de fragmento caulinar articulado com uma proporção média de largura/comprimento de 1:2,3. Espécime MN/UFRJ- 1977Pb.

Fig.6-Paracalamites montemorensis Millan 1977 nov. emend Impressão de fragmento caulinar articulado com uma proporção média de largura/comprimento de 1:1-1:1,99. Espécime MN/UFRJ- 1981PbB.

Fig.7- Botrychiopsis plantiana (Carr.) Archangelsky \& Arrondo 1971Fragmento de pina de forma triangular alargada, com quatro pínulas laterais quase completas. Espécime GP/3E-8953A. 


\section{Estampa 3}
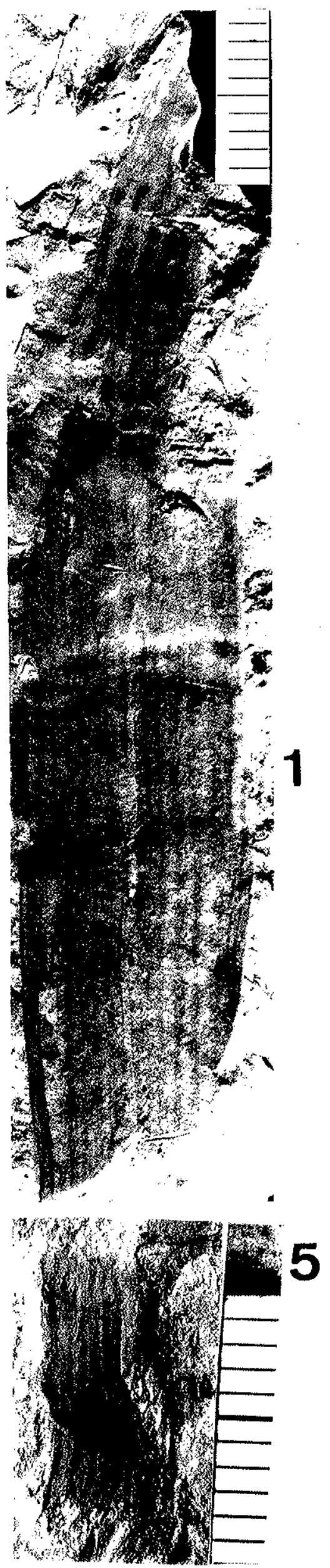
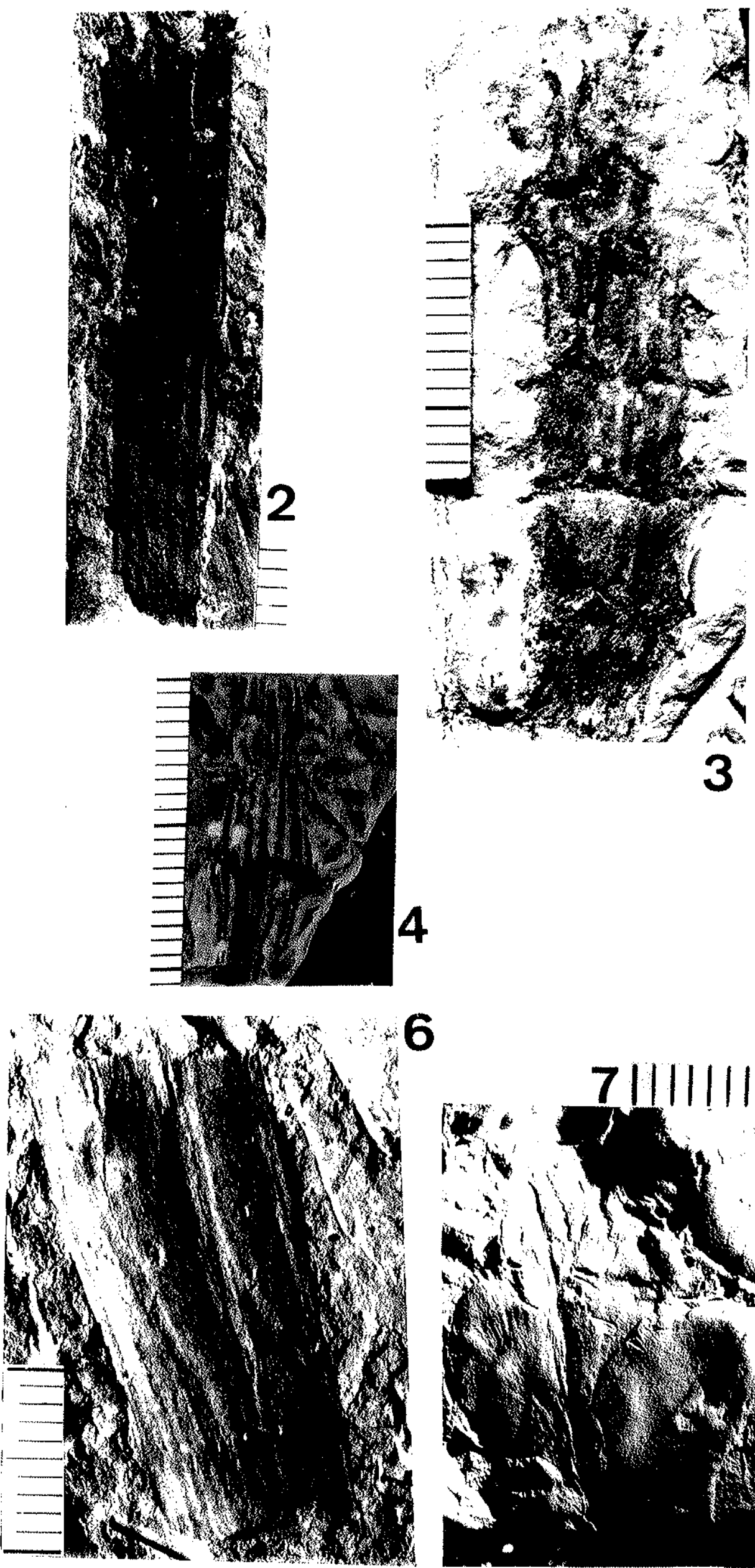

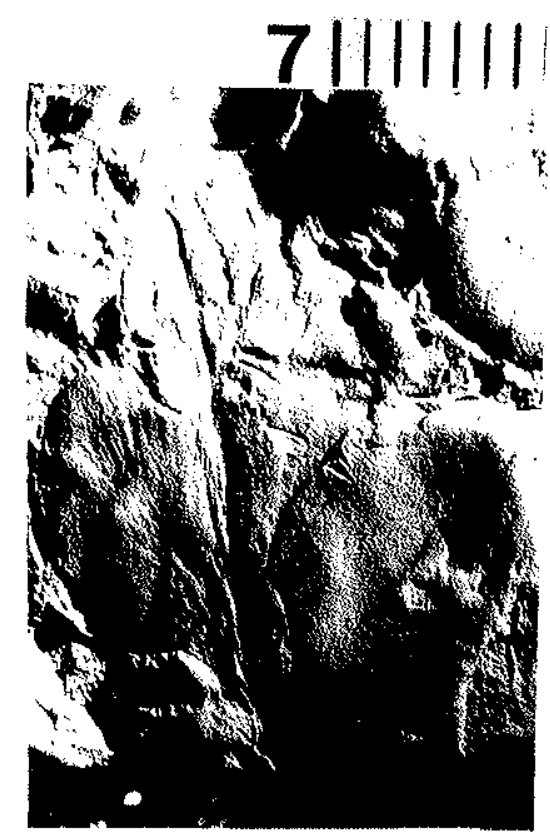




\section{Estampa A}

Fig.1- Botrychiopsis plantiana (Carr.) Archangelsky.\& Arrondo 1971- Setor médio-distal de fragmento de fronde bipinada, com 4 pinas, de baixo para cima, duas à direita, uma à esquerda e uma no ápice inseridas sub-opostamente. Espécime MN/UFRJ-1843Pb.

Fig.2- Botrychiopsis plantiana (Carr.) Archangelsky \& Arrondo 1971Fragmento do raque de pina, com seis pínulas laterais diferenciadas e de contorno ovado, sendo duas do lado esquerdo e basais e quatro do lado direito e médio-distais. Espécime MN/UFRJ-1845Pb.

Fig.3-Botrychiopsis plantiana (Carr.) Archangelsky \& Arrondo 1971 - Setor médio-distal de fragmenio de fronde bipinada, com quatro raques de pinas, apenas do lado esquerdo, sendo duas delas completas. Espécime MN/UFRJ$1847 \mathrm{~Pb}$.

Fig. 4- Botrychiopsis plantiana (Carr.) Archangelsky \& Arrondo 1971Fragmento de fronde da região mediana, com quatro raques de pinas do lado esquerdo de contorno oblongo quando individualizadas. Espécime MN/UFRJ$1852 \mathrm{~Pb}$. 


\section{Estampa 4}
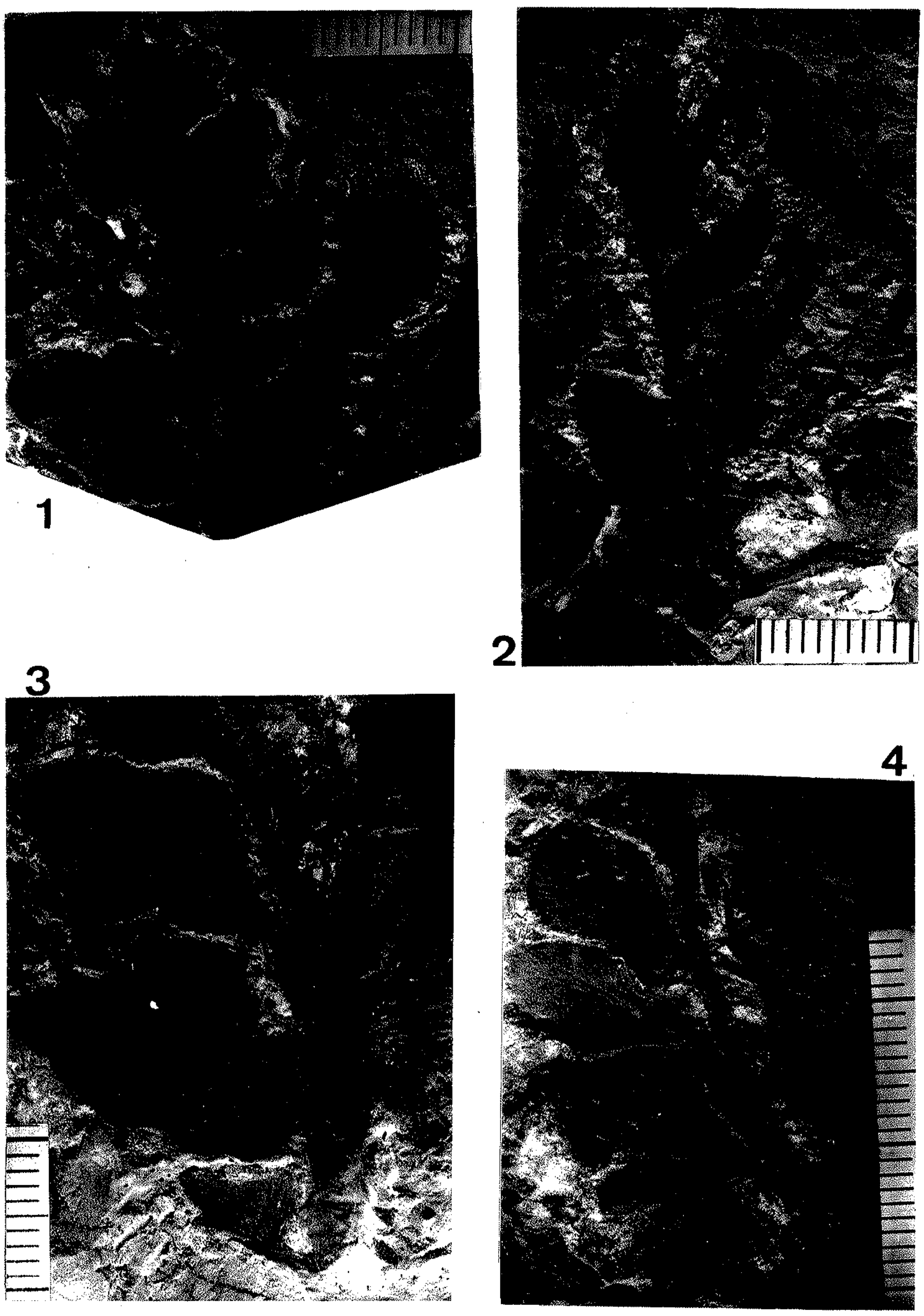


\section{Estampa 5}

Fig.1- Botrychiopsis plantiana (Carr.) Archangelsky \& Arrondo 1971 Fragmento de fronde, da região médio-distal, com quatro raques de pinas, de inserção alterna. Espécime MN/UFRJ-1848Pb.

Fig.2- Botrychiopsis plantiana (Carr.) Archangelsky \& Arrondo 1971Fragmento de pínula quase compleio, de forma esjatulada e venação dicotômica até três vezes, encurvando-se levemente antes de alcançar a borda da pínula. Espécime GP/3E8917.

Fig.3- cf. Eusphenopteris sp. Novik 1947- Pina apical com raque robusta e flexuosa, com cinco pínulas bilobadas de venação flabelinérvea. Espécime MN/UFRJ-1854Pb.

Fig.4- cf. Eusphenopteris sp. Novik 1947- Fragmento da porção mediana de fronde tri/tetrapinada, com duas raques de pinas. Espécime MN/UFRJ$1849 \mathrm{~Pb}$.

Fig.5- cf. Eusphenopteris sp. Novik 1947- Fragmento de pina, da região médio-distal, com raques secundárias e terciárias da fronde e seis pínulas. Espécime MN/UFRJ-1855Pb. 


\section{Estampa 5}

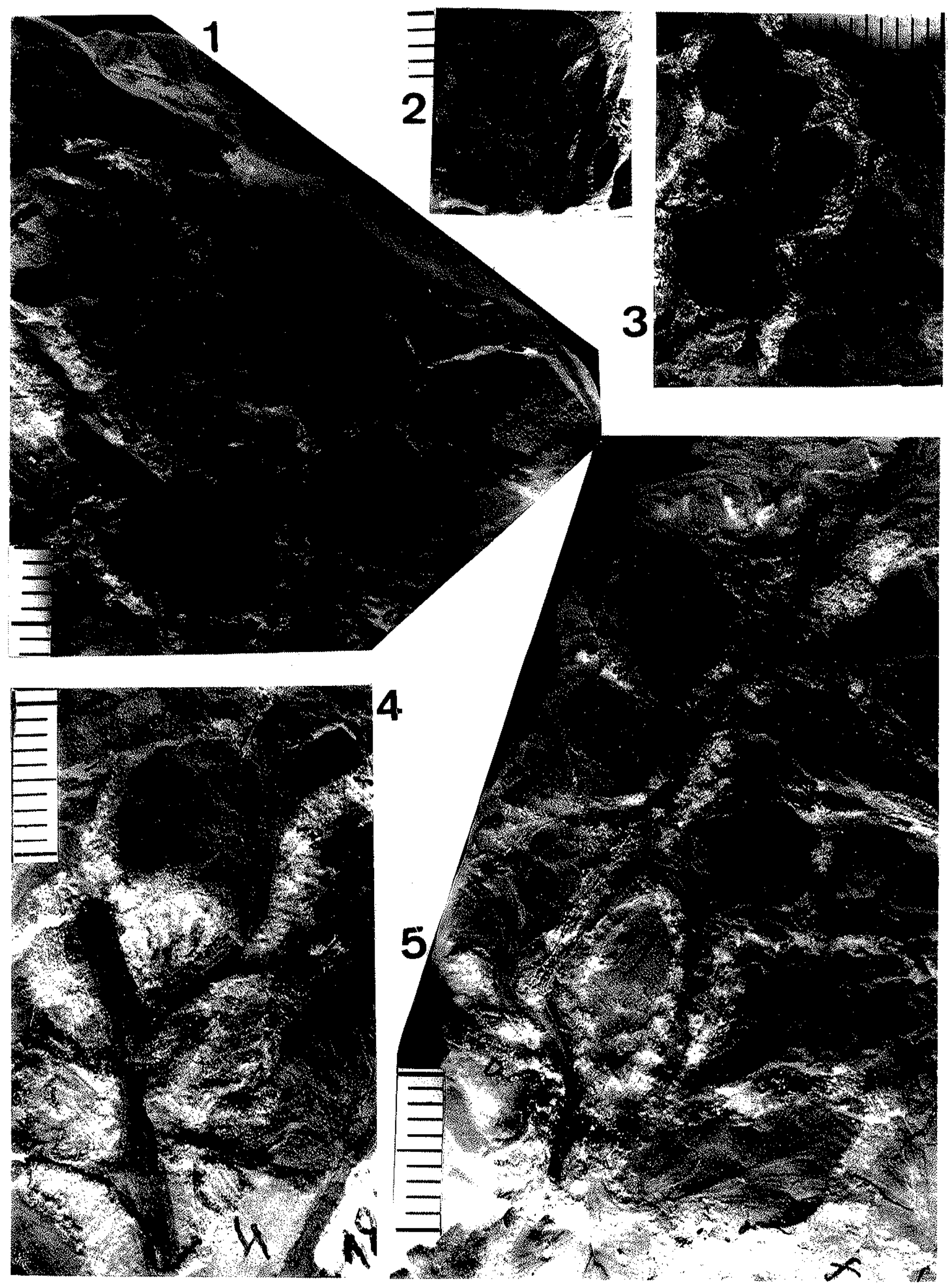




\section{Estampa 6}

Fig.1- cf. Eusphenopteris sp. Novik 1947-Fragmento de pina apresentando uma raque alada, flexuosa, com cinco pínulas arredondadas, flabelinérveas, dicotômicas e densas. Espécime MN/UFRJ-1846Pb.

Fig.2- Botrychiopsis plantiana (Carr.) Archangelsky \& Arrondo 1971Fragmento de pina de forma oblonga, com três pínulas quase completas. Espécime GP/3E8896.

Fig.3- cf. Eusphenopteris sp. Novik 1947- Fraṇmento de fronde tri/tetrapinado com pinas muito fragmentadas, e venação dicotômica, encurvada para a margem. Espécime MN/UFRJ-1853Pb.

Fig.4- Botrychiopsis plantiana (Carr.) Archangelsky \& Arrondo 1971Fragmento de pina de forma oblonga com quatro pínulas de venação dicotômica, levemente encurvada para a borda do limbo. Espécime GP/3E8914. 


\section{Estampa 6}
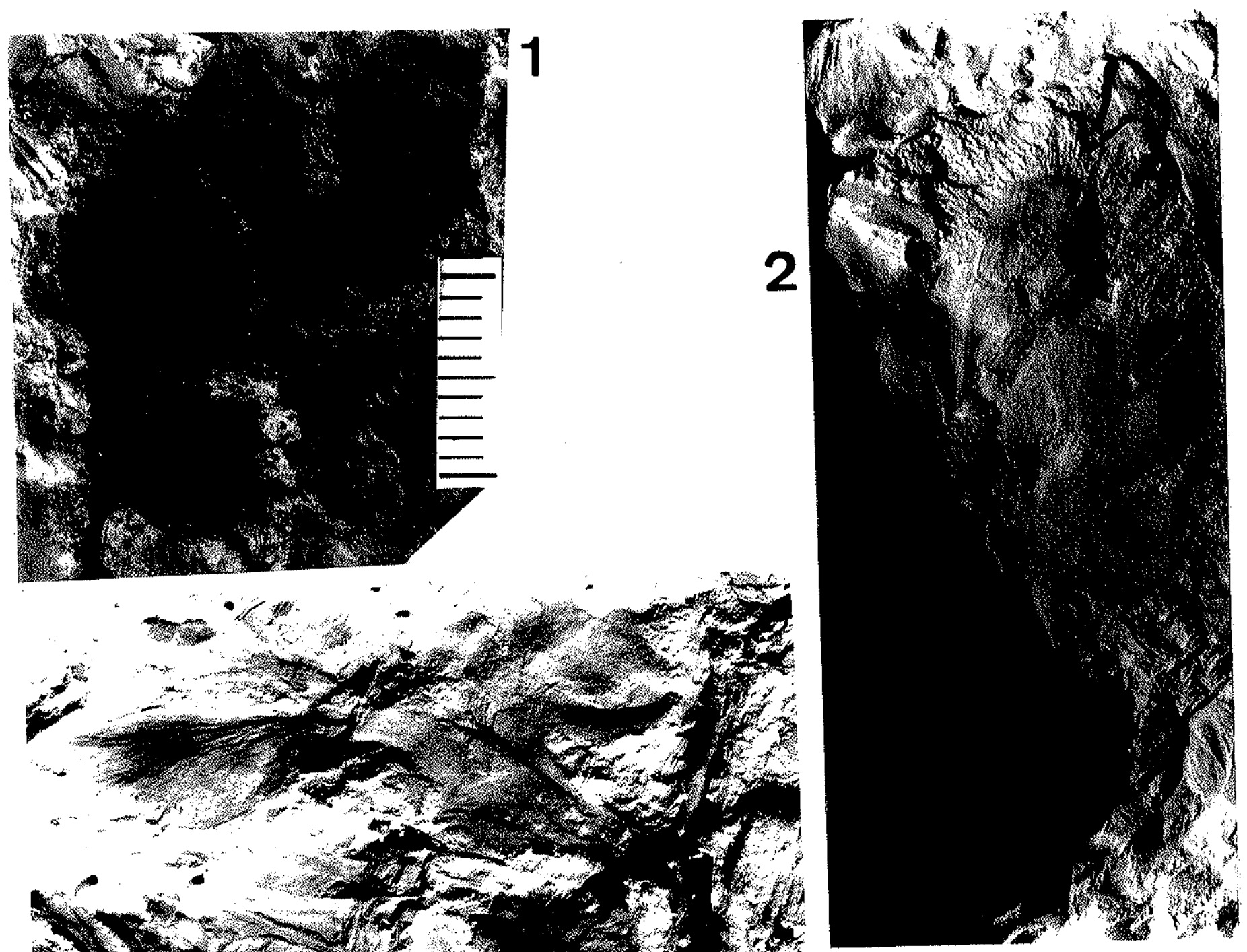

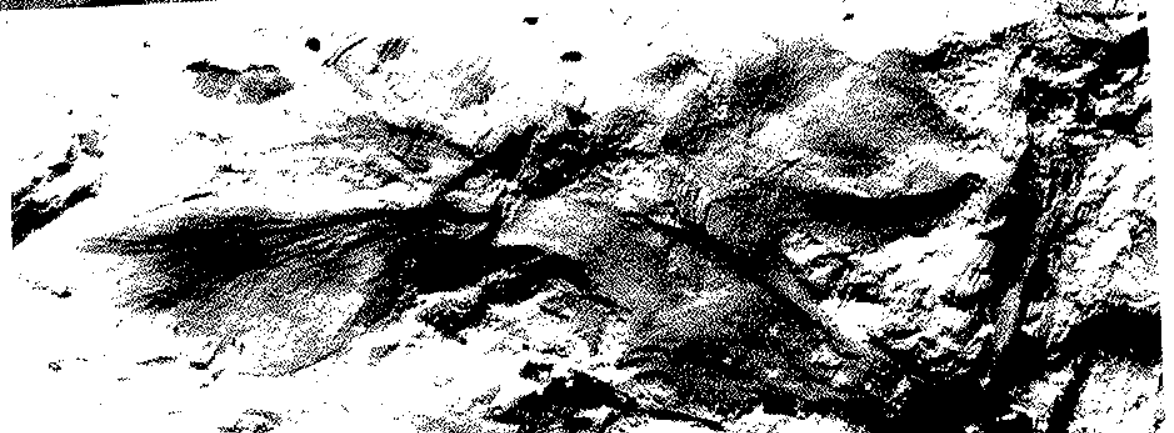

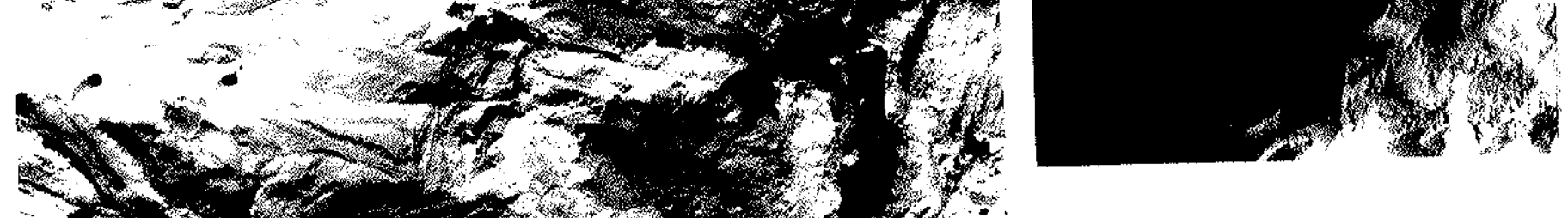

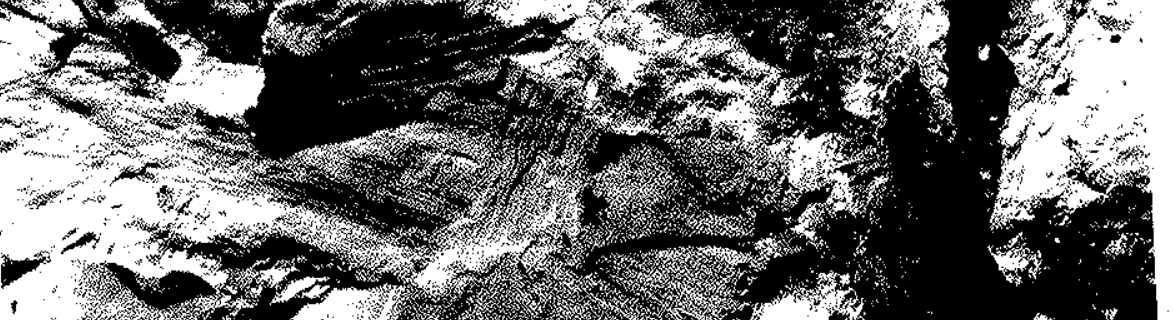

(1)
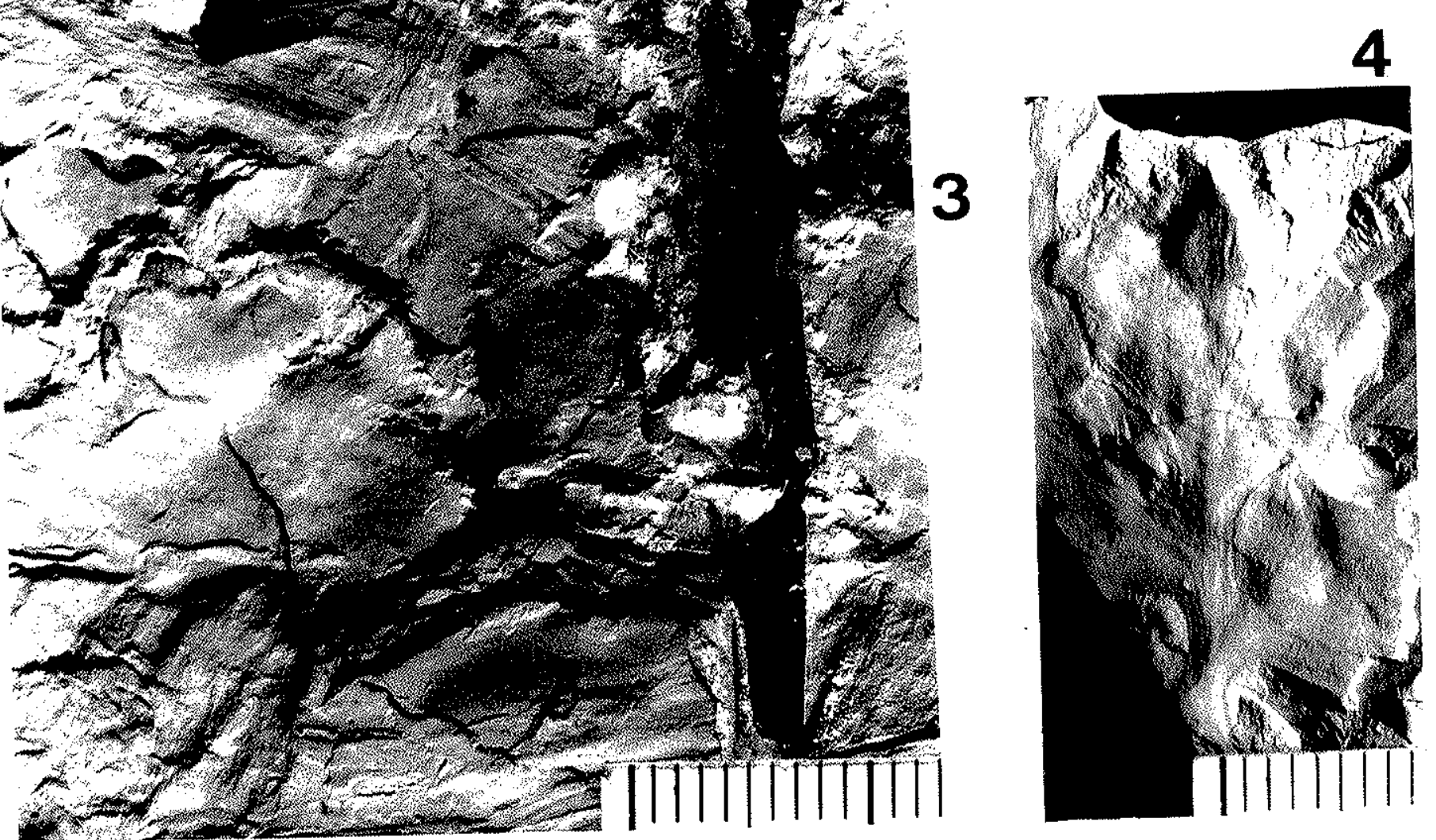


\section{Estampa 7}

Fig. 7- cf. Eusphenopteris sp. Novik 1947- Fragmento de fronde da região mediana de fronde tripinada, com quatro raques de pinas portando pinulas reniformes a flabeliformes de venação dicotômica, densa, e curvada suavemente para as margens laterais. Espécime MN/UFRJ-1842Pb. 


\section{Estampa 7}
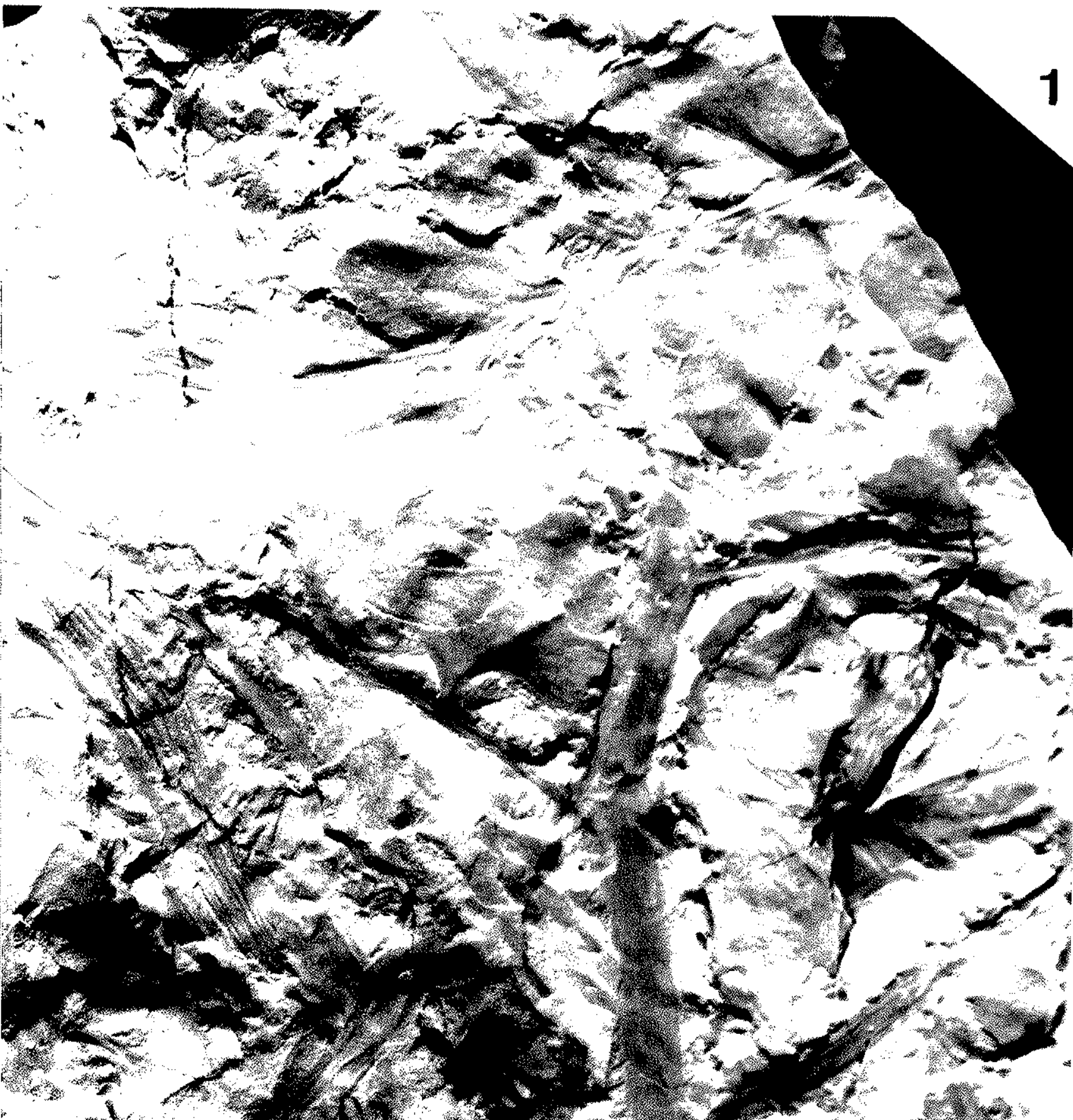

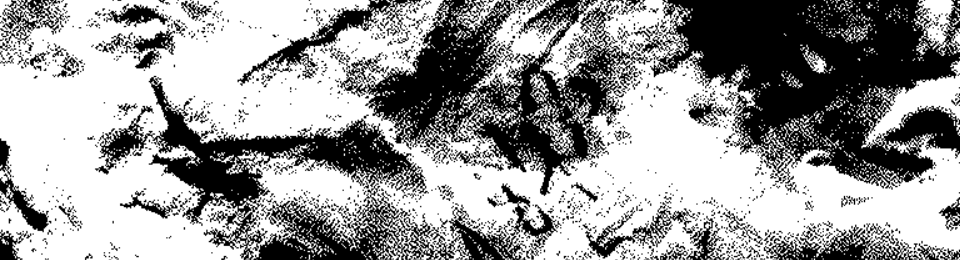

$10, \frac{1}{3}, 3$

$3 d<+3,20$

M 30,15

4. 


\section{Estampa 8}

Fig.1- Botrychiopsis plantiana (Carr.) Archangelsky \& Arrondo 1971Fragmento de pina quase completo, elíptica a subtriangular ampla, composta por cinco pínulas de margem inteira fragmentadas. Espécime GP/3E8952A.

Fig.2- cf. Eusphenopteris sp. Novik 1947- Fragmento de fronde tri/tetrapinado, com raque secundária portando de um fragmento de raque de pina de disposição quase perpendicular, com uma pínula basal flabeliforme e catadrômica. Espécime MN/UFRJ-1851Pb.

Fig.3- Botrychiopsis plantiana (Carr.) Archangelsky \& Arrondo 1971Fragmento de pina, de forma amplamente elíptica a subtriangular, com sete pínulas. Espécime GP/3E8944.

Fig.4- Nothorhacopteris cf. Nothorhacopteris argentinica Archangelsky 1983- Fragmentos de pínulas flabeliforme, com venação dicotômica isoladas, dispostas caoticamente na porção distal de um fragmento aflebóide. Espécime GP/3E8928A. 


\section{Estampa 8}
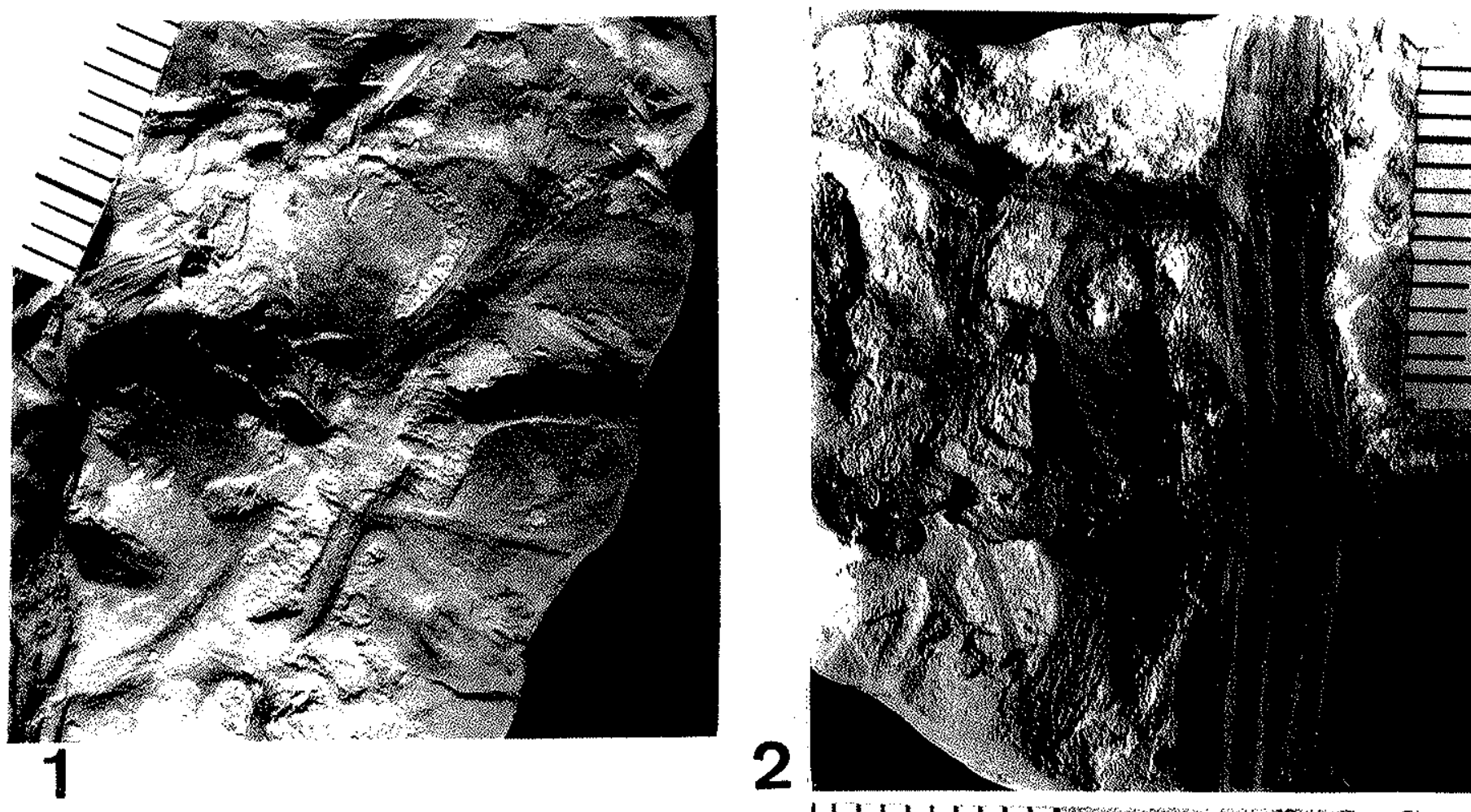

$7 \mathrm{~N}$

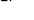

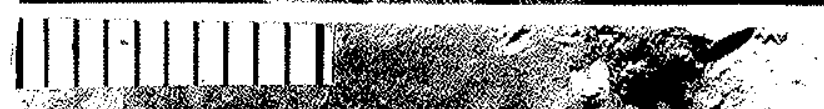

20,

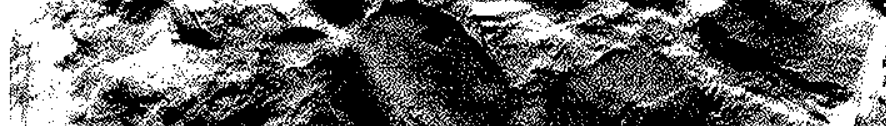

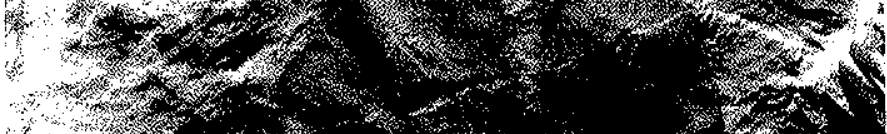

ars.
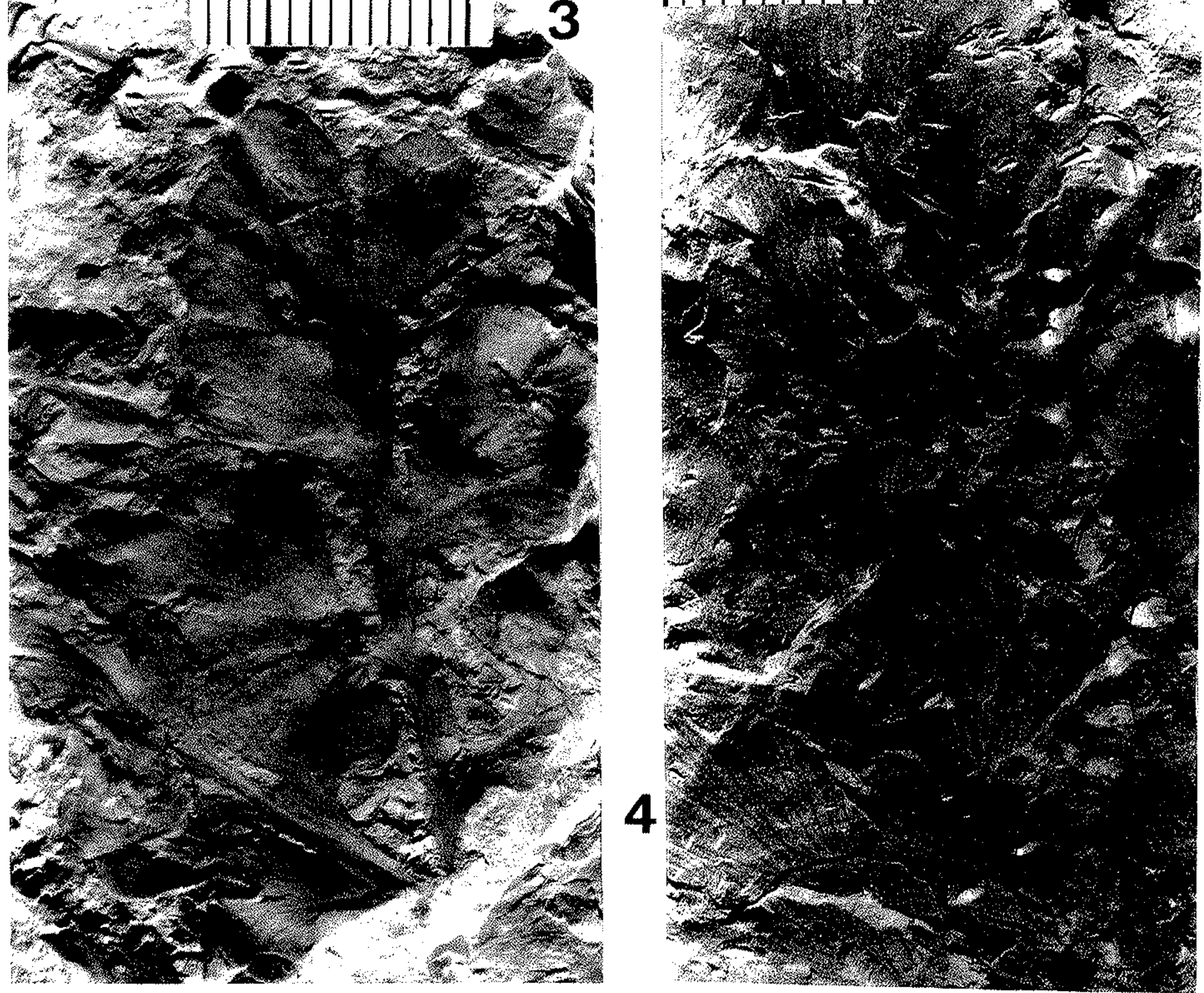


\section{Estampa 9}

Fig.1- Botrychiopsis plantiana (Carr.) Archangelsky \& Arrondo 1971Fragmento basal de pina, de forma elíptica, com três pínulas apecioladas visíveis. Espécime GP/3E9027.

Fig.2- cf. Eusphenopteris sp. Novik 1947-Raque de fronde, flexuosa e fragmentada, de provável região médio-distal, portando uma raque de emergindo a mais ou menos $85^{\circ}$. Espécime MN/UFRJ-1844Pb.

Fig.3- Botrychiopsis plantiana (Carr.) Archangelsky \& Arrondo 1971- Pínula individualizada, de contorno obovado, com venação dicotômica, densa e suavemente curvada para a margem. Espécime MN/UFRJ-1850Pb. 


\section{Estampa 9}
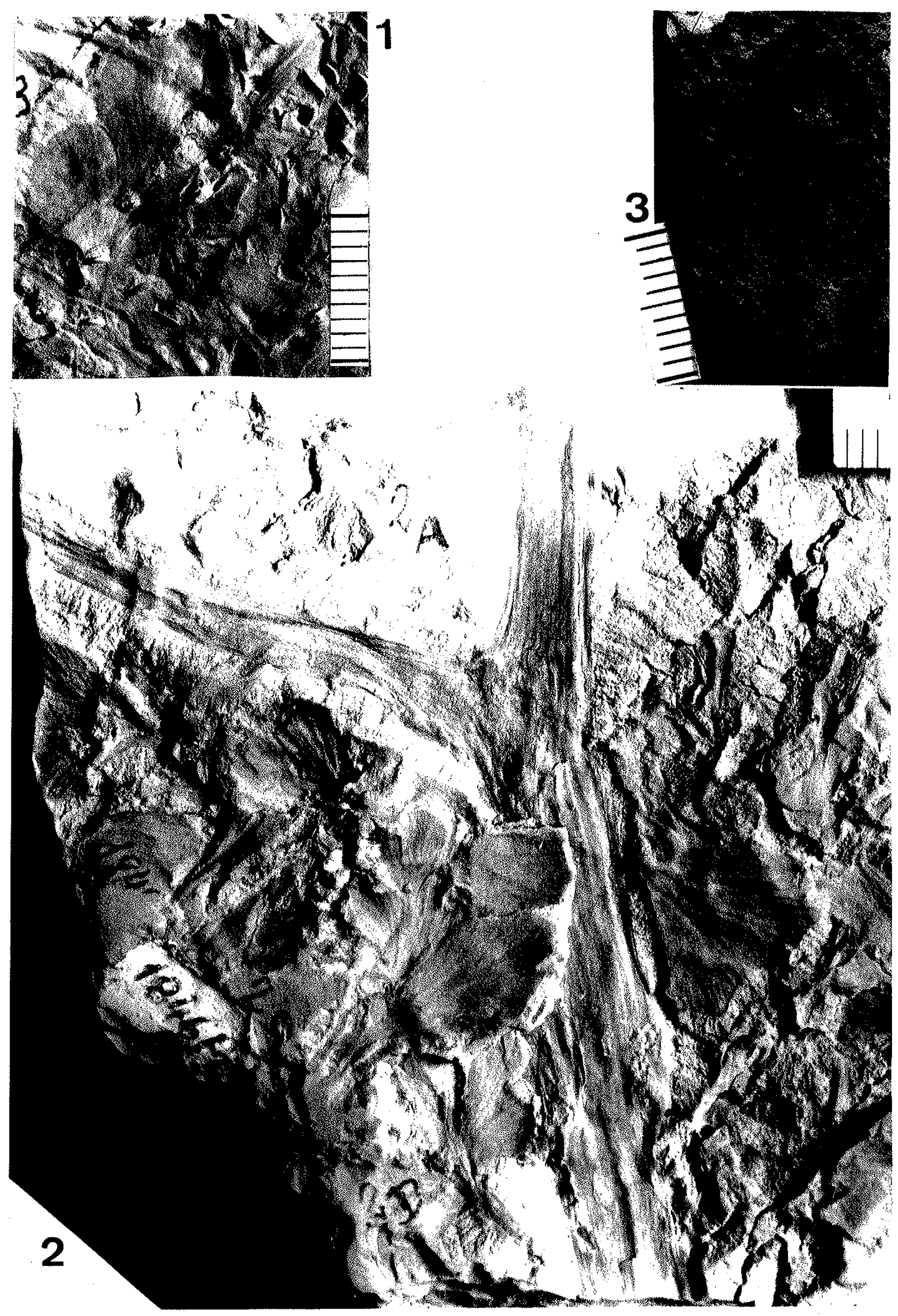


\section{Estampa 10}

Fig.1. Aflébia de Nothorhacopteris cf. N. argentinica Archangelsky 1983Porção basal aflebóide de uma fronde de Nothorhacopteris cf. N. argentinica, com forma foliar oblonga, feixe mediano crasso e lâmina foliar de lobulação marginal ampla e suave melhor preservada do lado direito, com venação secundária dicotômica emergindo em ângulo agudo $\left(15-20^{\circ}\right)$ e encurvando-se a seguir (quase $90^{\circ}$ ) para a margem. Espécime GP/3E-8928B. 


\section{Estampa 10}

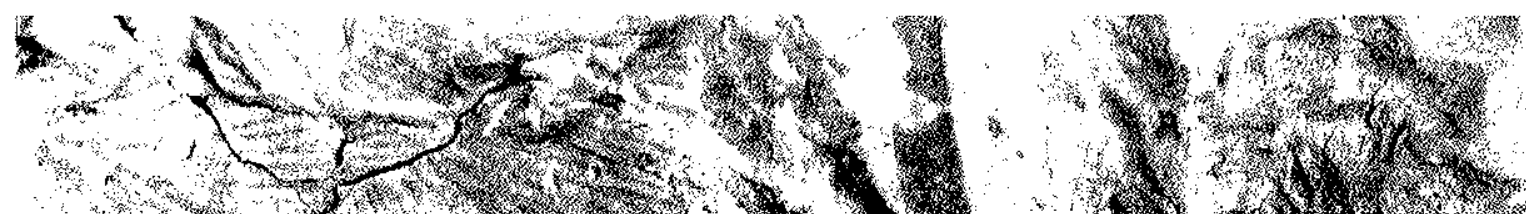

3
3

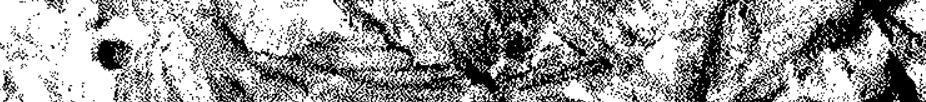
H.

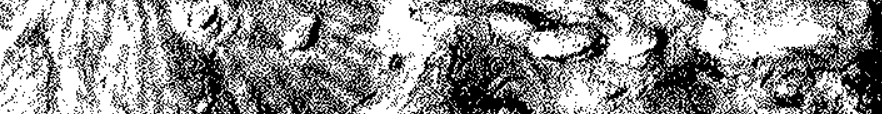
...

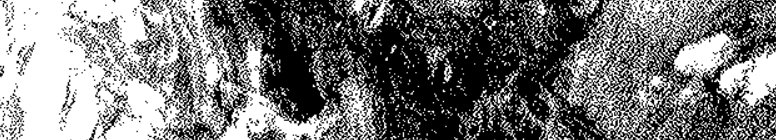

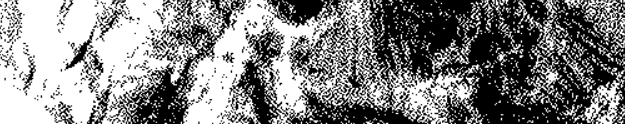

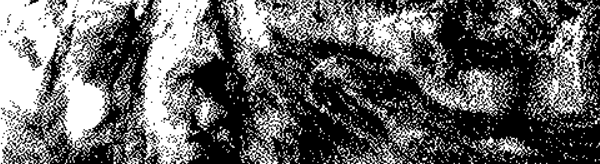

Y.t.

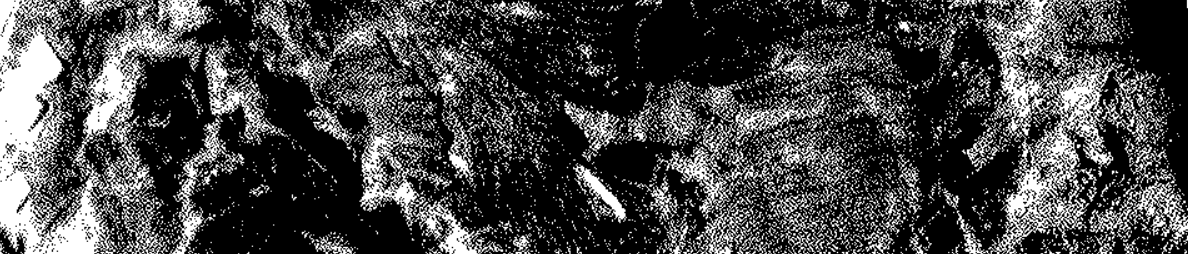

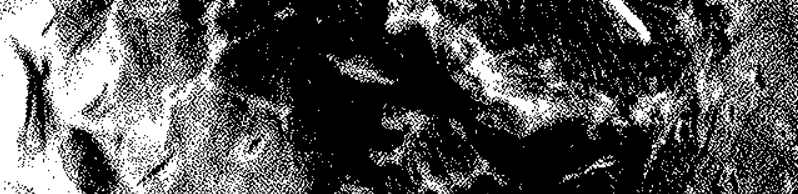

3
3
3

(1)

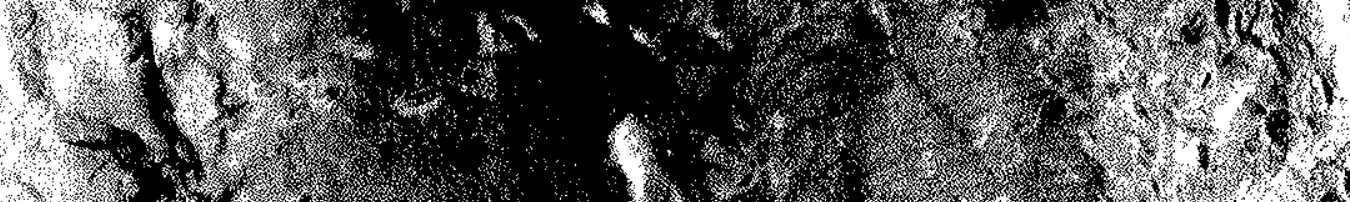

m

1 H. 1.

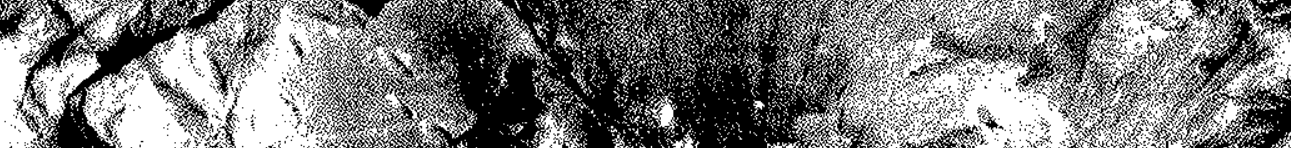

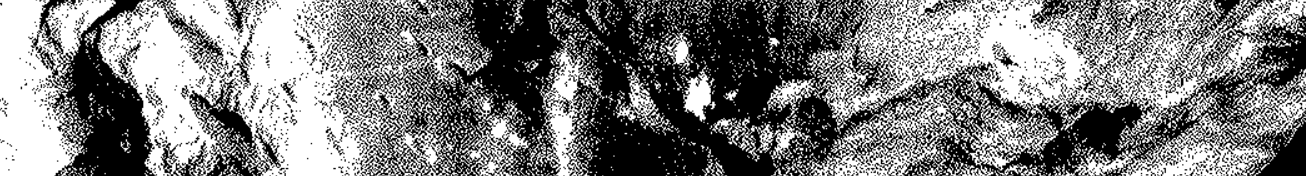

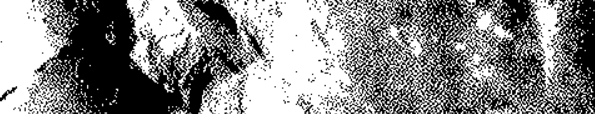

a

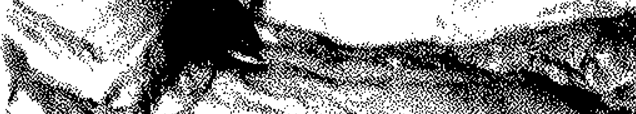




\section{Estampa 11}

Fig.1. Punctatisporites gretensis Balme \& Hennelly 1956 (Coordenadas-IGP-186B-M38) 0.738x

Fig.2. Punctatisporites lucidulus Playford \& Helby 1968 (Coordenadas-IGP-286C-S47) $0.738 x$

Fig.3. Granulatisporites austroamericanus Archangelsky \& Gamerro 1979 (Coordenadas-1G-P-286A-S31/3) 0.738x

Fig.4. Verrucosisporites morulatus (Knox) Smith \& Butterworth 1967 (Coordenadas-1G-P-286C-G31/4) 0.738x

Fig.5. Dibolisporites disfacies Jones \& Truswell 1992 (Coordenadas-IG-P. 286B-N43) 0.738x

Fig.6. Raistrickia pinguis Playford 1971 (Coordenadas-IG-P-286A-K42/2) $2805 x$

Fig.7. Ahrensisporites cf. Ahrensisporites cristatus (Potonié \& Klaus) Dettman 1963 (Coordenadas-IG-P-286B-T35/3) 0.738x

Fig.8. Reticulatisporites sp. (Coordenadas-IG-P-286C-W45/1) 0.738x

Fig.9. Murospora sp. (Coordenadas-IG-P-286A-L24/2) 0.738x

Fig.10. Vallatisporites ciliares (Lüber) Sullivan 1964 (Coordenadas-IG-P286-B-N43) 0.738x

Fig.11. Plicatipollenites densus Srivastava 1970 (Coordenadas-IG-P-286-AR34/4) $2.805 x$ 


\section{Estampa 11}
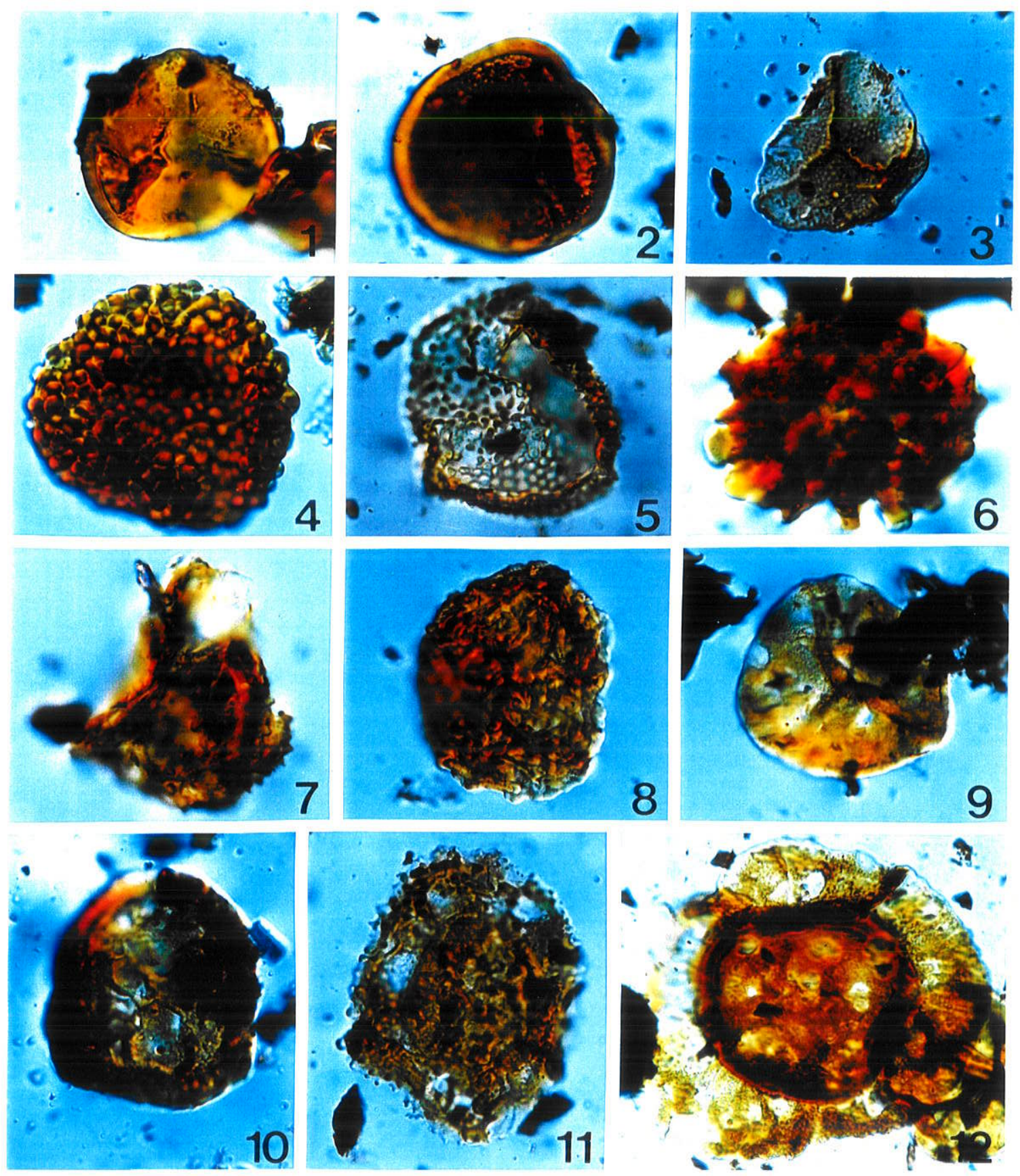


\section{Estampa 12}

Fig.1. Plicatipollenites malabarensis (Potonié \& Sah) Foster 1975 (Coordenadas-IG-P-286A-K42/1) 2.805x

Fig.2. Potonieisporites brasiliensis (Nahuys, Alpern \& Ybert) Archangelsky \& Gamerro 1979 (Coordenadas-IG-P-286A-Q32/1) 3.333x

Fig.3. Potonieisporites magnus Lele \& Karin 1971 (Coordenadas-IG-P286A-K32/1) $3.333 \mathrm{x}$

Fig.4. Potonieisporites congoensis Bosi \& Maheshwari 1968 (CoordenadasIG-P-286A-M30/1) $0.738 x$

Fig.5. Caheniasaccites flavatus (Bose \& Kar 1966) Azcuy \& Di Pasquo 2000 (Coordenadas-IG-P-286B-K34/1) 2.646x

Fig.6. Tasmanites sp. (Coordenadas-IG-P-286A-Q49/2) $2.805 x$ 


\section{Estampa 12}

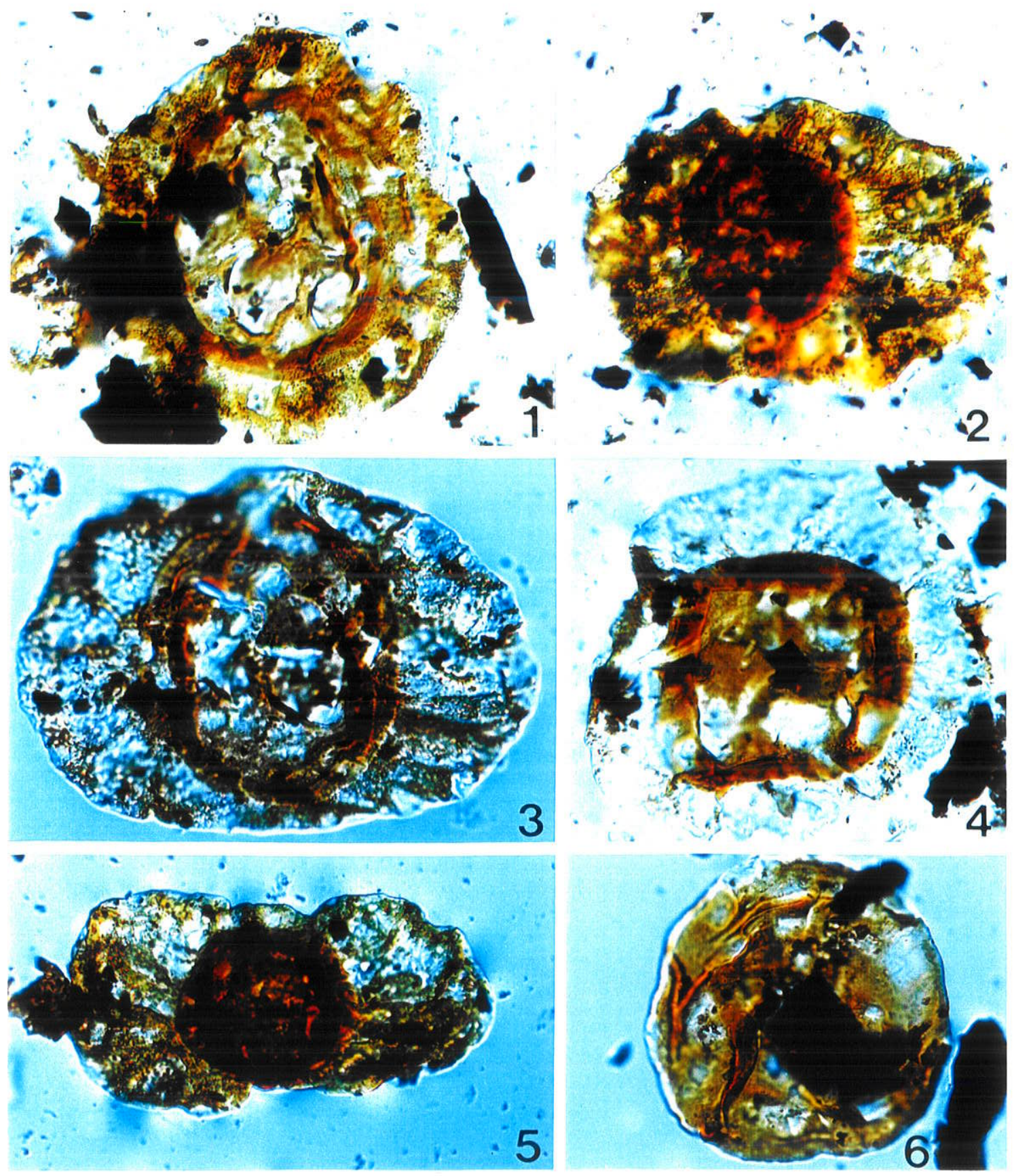




\section{Estampa 13}

Fig. 1. Entrada da mina de carvão, antiga e abandonada, da fazenda Santa Marta (jazigo fossilifero), Itapeva (SP).

Fig.2. Afloramento fitofossilífero coma entrada da mina à direita. De baixo para cima vêem-se: ritmito acinzentado de lâminas finas, argila avermelhada fossilifera e arenito amarelado com estratificação cruzada no topo.

Fig. 3. Vista geral da mata ciliar onde se localiza o jazigo fossilífero (mina de carvão abandonada) da fazenda Santa Marta, Itapeva (SP). 


\section{Estampa 13}

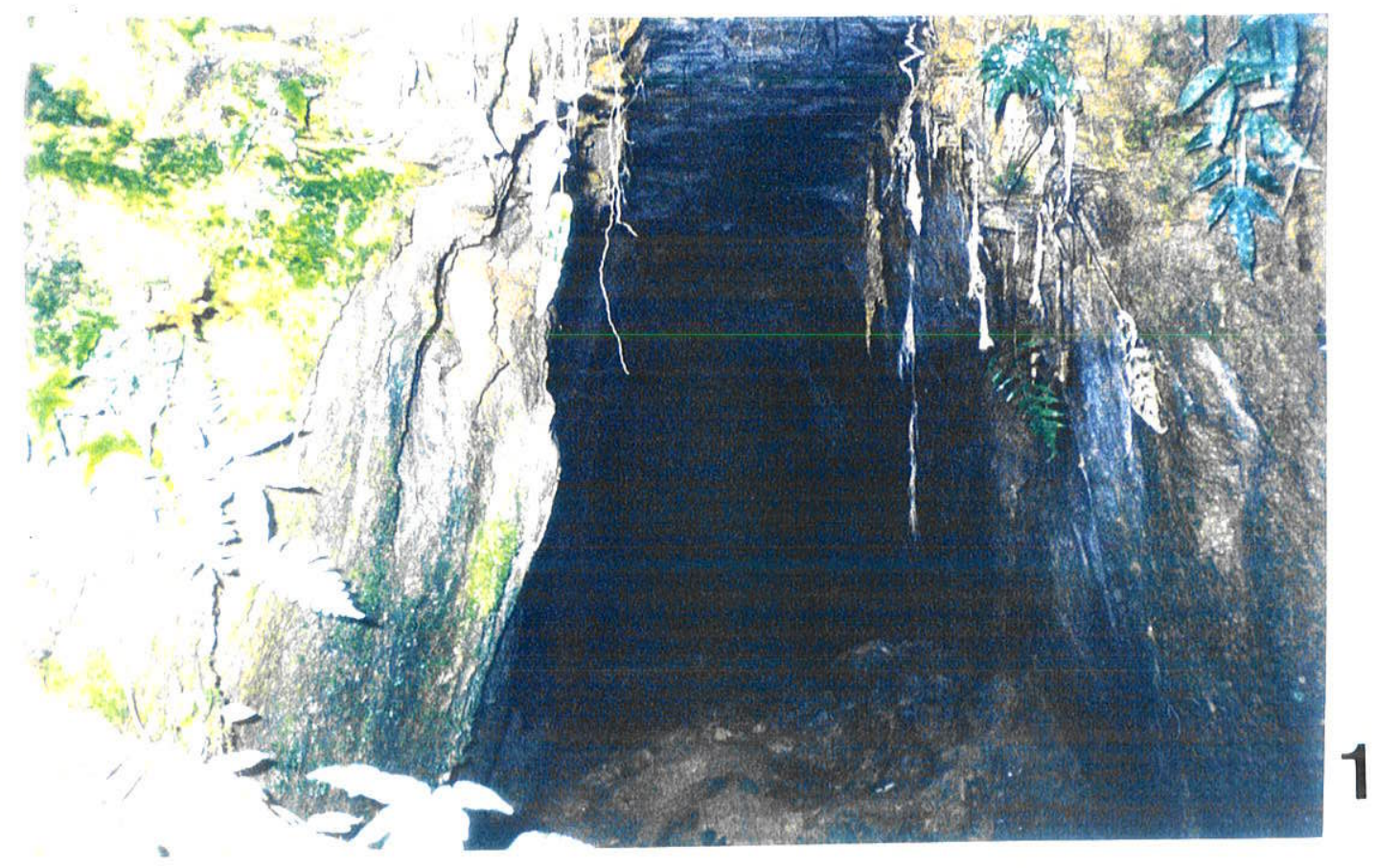

2

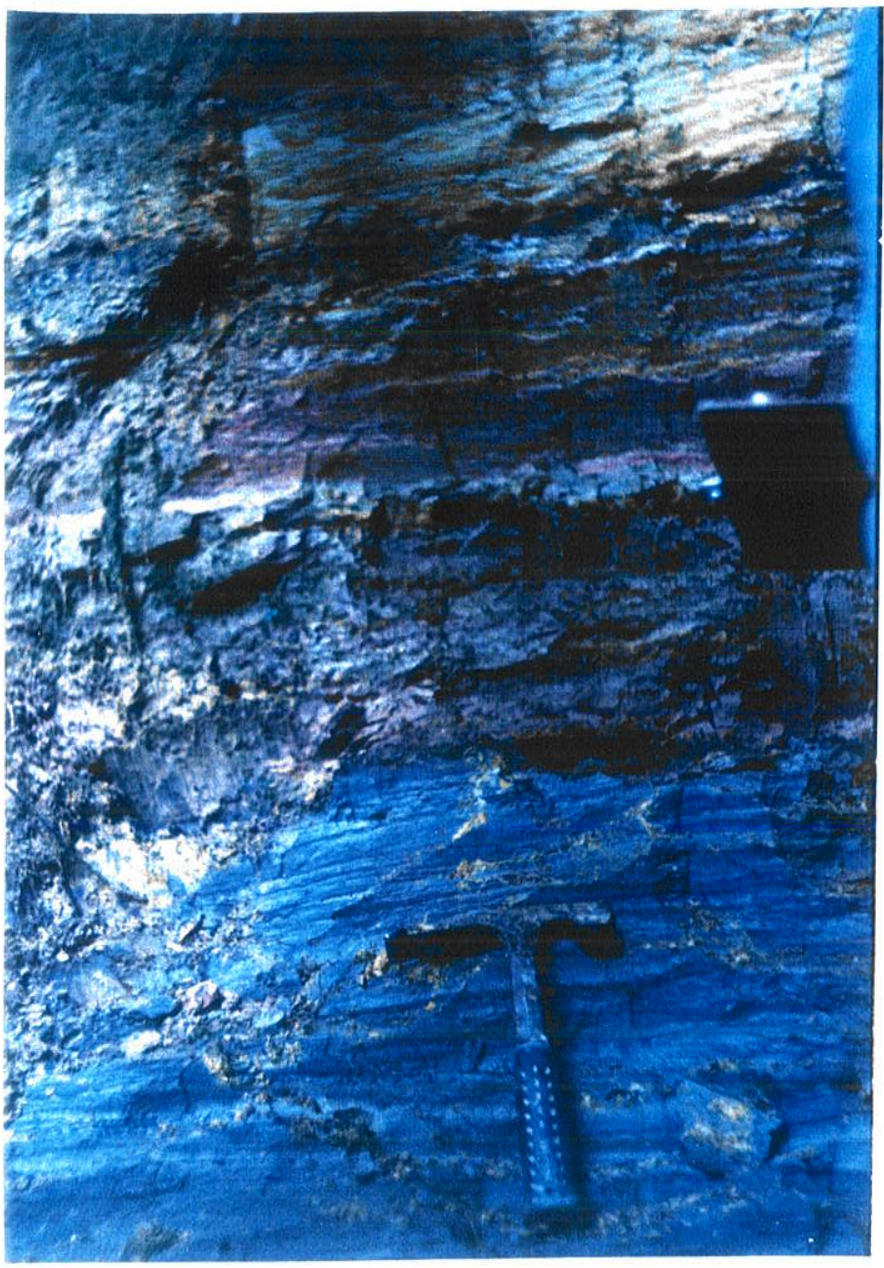

3

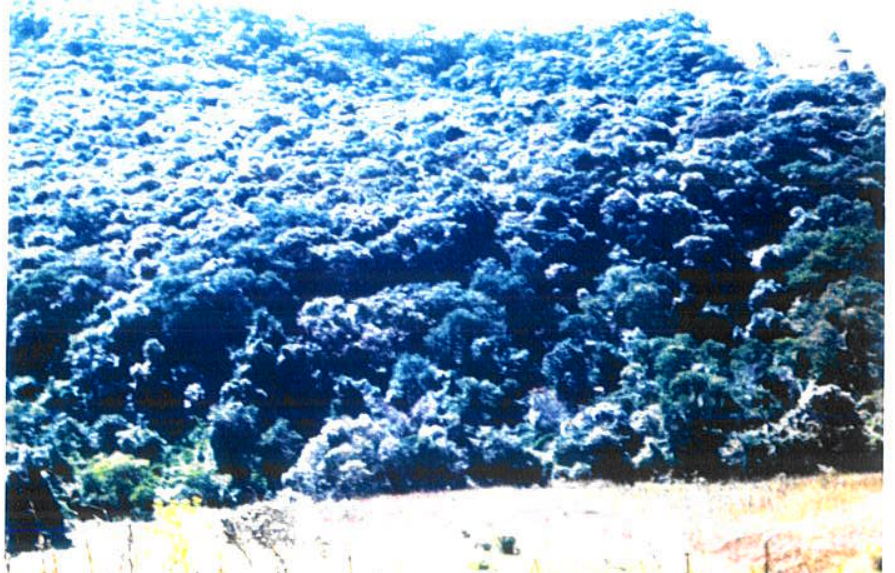

$$
\text { a }
$$

